\title{
SAFETY FOR BATTERED WOMEN IN A TEXTUALLY MEDIATED LEGAL SYSTEM
}

by

\author{
Ellen Pence
}

A thesis submitted in conformity with the requirements

for the degree of Doctor of Philosophy

Graduate Department of Sociology in Education

University of Toronto

(C) Copyright by Ellen L. Pence 1997 
Acquisitions and Bibliographic Services

395 Wellington Street Ottawa ON K1A ON4 Canada
Acquisitions et services bibliographiques

395. ne Wellington Ottawa ON KIA ONA Canada
The author has granted a nonexclusive licence allowing the National Library of Canada to reproduce, loan, distribute or sell copies of this thesis in microform, paper or electronic formats.

The author retains ownership of the copyright in this thesis. Neither the thesis nor substantial extracts from it may be printed or otherwise reproduced without the author's permission.
L'auteur a accordé une licence non exclusive permettant à la Bibliothèque nationale du Canada de reproduire, prêter, distribuer ou vendre des copies de cette thèse sous la forme de microfiche/film, de reproduction sur papier ou sur format électronique.

L'auteur conserve la propriété du droit d'auteur qui protège cette thèse. $\mathrm{Ni}$ la thèse ni des extraits substantiels de celle-ci ne doivent être imprimés ou autrement reproduits sans son autorisation. 


\title{
SAFETY FOR BATTERED WOMEN \\ IN A TEXTUALLY MEDIATED LEGAL SYSTEM \\ Degree of Doctor of Philosophy, 1997 \\ Ellen L. Pence \\ Graduate Department of Sociology in Education \\ University of Toronto \\ Ontario Institute for Studies in Education
}

\begin{abstract}
Using Dorothy Smith's work on institutional ethnography I have conducted an investigation of the Duluth, Minnesota, criminal court system which shows how the safety of battered women becomes marginalized in the process of managing cases. Those efforts which have been made to build safety into this system have been piecemeal. The complexity of the case processing system results in a single case being processed by six levels of government. over a dozen agencies. and as many as thirty individuals. I have shown that the system is textually mediated at every point of institutional action and is embedded in an institution which is hierarchical, incident focused, bureaucratically fragmented, and based in an adversarial process of resolving cases. Each of these features of criminal law compromises the likelihood of practitioners taking protective measures for battered women. I have shown that the daily routines of the legal system are linked to ideological ways of interpreting women's lives and extended relations of social ruling. I have proposed conducting an interagency safety audit as a legal reform strategy which can identify concrete ways to insert victim safety into domestic-assault case management procedures.
\end{abstract}


Table of Figures

Table of Appendices

Acknowledgments . . . . . . . . . . . . . . . . . . . . . 1

Abstract . . . . . . . . . . . . . . . . . . 3

Chapter 1: The Project . . . . . . . . . . . . . . . Page 4

Chapter 2: Legal Advocacy and the Battered Women's Movement . . . . . . . . . Page 22

Chapter 3: Institutional Advocacy and Criminal Justice Reform Efforts . . . . . . Page 33

Chapter 4: Institutional Technology, Jobs, and Specialization . . . . . . . . . Page 60

Chapter 5: A Textually Mediated System . . . . . . . . . . . . . . . . Page 90

Chapter 6: The Administrative and Regulatory Texts at Work . . . . . . . . Page 106

Chapter 7: Legal Arguments and Extended Relations of Ruling . . . . . . . . . . . Page 124

Chapter 8: Politics of Change . . . . . . . . . . . . . . . . . Page 151

Chapter 9: Safety Audit $\ldots \ldots \ldots \ldots \ldots \ldots \ldots \ldots \ldots \ldots \ldots$. . . . . . . . . . . 184

Reference List . . . . . . . . . . . . . . . . . . . . . . . . . . Page 197

Appendices 


\section{TABLE OF FIGURES}

Figure 1: Collecting Information $\ldots \ldots \ldots \ldots \ldots \ldots \ldots \ldots \ldots \ldots \ldots \ldots \ldots \ldots$

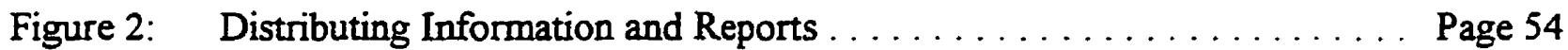

Figure 3: Multiple Readings of a Domestic Assault Report ............ Page 73

Figure 4: Key Intervention Points in Processing a Criminal Domestic Assault Case . Page 76

Figure 5: Immediate Intervention and Initial Investigation: Dispatching Squad . . . Page 88

Figure 6: Beth's Reality . . . . . . . . . . . . . . . . . . . . Page 107

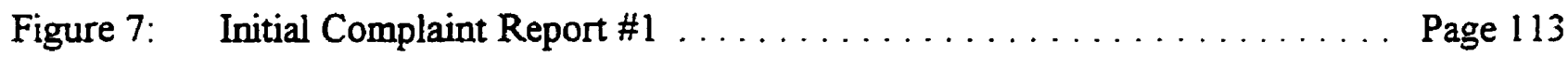

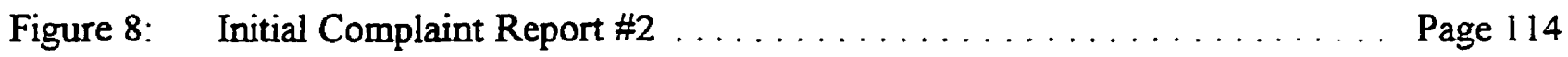

Figure 9: Duluth Police Policy on Domestic Violence .............. Page 118

Figure 10: Duluth Police Protection Order Policy ................... Page 119

Figure 11: Domestic Abuse Act-Violation of an Order for Protection ........ Page 120

Figure 12: Probation Referral Sheet . . . . . . . . . . . . . . . . Page 165

Figure 13: Domestic Violence Related Misdemeanor Sentencing Matrix . . . . . . . Page 169

Figure 14: Report Writing Checklist . . . . . . . . . . . . . . . . . Page 172

Figure 15: Domestic Assault Report Feedback Form . . . . . . . . . . . . . Page 174

Figure 16: Addition to Victim Advocate Arrest Follow-Up Form . . . . . . . . . . Page 179 


\section{TABLE OF APPENDICES}

Appendix A: Transcript from Rasmusson Hearing

Appendix B: Immediate Intervention and Initial Investigation

B-1 Dispatching Squad

B-2 Police Response to Domestic Call and Decision to Arrest

B-3 Booking and Holding Suspect

B-4 Arrest Report Preparation and Processing of a Misdemeanor Domestic Assault

B-5 Detective Bureau Investigation for Gross Misdemeanor and Felony Assault

Appendix C: Dispatcher Screen

Appendix D: Arrest Report

Appendix E: Excerpt of Transcript from State of Minnesota vs. Benjamin George Barns, Sentencing Hearing

Appendix F: Transcript from State of Maryland vs. Kenneth L. Peacock, Sentencing Hearing Appendix G: Presentence Investigation Form

Appendix H: Probation Agreement

Appendix I: Probation Officer Recommendation Form 


\section{ACKNOWLEDGMENTS}

I have never been a good student. I had to petition to get into the University of Minnesota in 1966 because both my high school grades and my entrance exam scores were so low. I was admitted into the General College, where I studied with some of the university's finest athletes. I dropped out in 1969. Twenty-one years later I completed my B.A. because Margo Dallas and Bob Brenning encouraged me and helped me through the process.

I owe a special thanks to Tineke Ritmeester, who persuaded me to study in Canada so that I would be exposed to a more global feminist perspective. She also took dozens of late night calls from me during my first year at the Ontario Institute for Studies in Education (OISE) as I struggled to understand the language of academia. Roxana $\mathrm{Ng}$ helped me successfully negotiate the OISE application process despite my rather bleak undergraduate transcript. I want to thank Connie Chapman, Shamita Das Dasgupta, Martha McMahon, and Annie Bergman for letting me stay at their homes as an escape for writing and giving me critical feedback on various chapters of this manuscript.

Several colleagues in Toronto helped me solve the problems of conducting my life as a student in Toronto and a researcher in Duluth. I especially want to thank Fiona Hart, Sandra Moffett, Mathew Searle, Devika Steffanson, and Diane Mossman for their help.

Once I had made the decision to go to graduate school, my co-workers did everything short of paying my tuition to get me through. Heather Dreessen, Tammy Helgesen, Denise Lisdahl, Tara Holbeck, Denise Gamache, Coral McDonnell, Nancy Helgesen, and Shelly Stoffel all helped me find files, fixed my pitiful charts, reformatted my typing, read endless drafts, and helped me in ways I am sure I didn't even recognize.

I am indebted to the Domestic Abuse Intervention Project (DAIP), where I have worked for 16 years. As a group we have been an important part of a historic social movement. We were the first grassroots group to break through the barrier of institutional resistance to establishing community-monitored interagency policies (including policies mandating arrest, promoting 
aggressive prosecution, imposing increasingly harsh penalties on repeat offenders, and requiring a feminist-based educational model for abusers). This speaks to the excellence of our group as well as to that of the leaders in our police and court system. To my co-workers and the many practitioners who have lent to my experience and to this specific endeavor, I am eternally grateful.

The Duluth police and court system and the DAIP have been the recipients of many prestigious awards, which we have always accepted as a group. In a few months I will have a Ph.D. I will be called Dr. Pence and be afforded all of the privileges and opportunities that title offers. It seems only fair that we should all receive this honor together.

I would like to thank my committee members, Helen Lenskyj and George Dei, for their valuable comments in reading the first several drafts of this dissertation.

I thought I would write this dissertation in a month and spend a few months fixing it up while I continued to work. I never imagined I would experience the intellectual insecurities I have seen so many other women struggle through. I was wrong. Two people saw me through this, Dorothy Smith and Kate Regan. Anything I say about these women would just send a "sap" meter off the scale, so I will say only a few words. Dorothy Smith was the perfect advisor for me. She gave me time whenever I asked for it, kept me from getting insecure, made me dump lots of extraneous junk from my writing, kept me focused on my approach, and assumed without doubt that I would finish this. She never let her brilliance get in the way of my learning from her. I am most grateful for her book, Texts, Facts, and Femininity. It has fundamentally changed the way I look at institutional advocacy. I owe very special thanks to Kate Regan, who has contributed her keen sense of clarity and style to every page of this manuscript.

Finally, I thank my mother, with whom I have worked in the battered women's movement for more than 20 years. She has always believed in me and has instilled in me a sense of endless possibility. 


\title{
SAFETY FOR BATTERED WOMEN \\ IN A TEXTUALLY MEDIATED LEGAL SYSTEM \\ Degree of Doctor of Philosophy, 1997 \\ Ellen L. Pence \\ Graduate Department of Sociology in Education \\ University of Toronto \\ Ontario Institute for Studies in Education
}

\begin{abstract}
Using Dorothy Smith's work on institutional ethnography I have conducted an investigation of the Duluth, Minnesota, criminal court system which shows how the safety of battered women becomes marginalized in the process of managing cases. Those efforts which have been made to build safety into this system have been piecemeal. The complexity of the case processing system results in a single case being processed by six levels of government, over a dozen agencies, and as many as thirty individuals. I have shown that the system is textually mediated at every point of institutional action and is embedded in an institution which is hierarchical, incident focused, bureaucratically fragmented, and based in an adversarial process of resolving cases. Each of these features of criminal law compromises the likelihood of practitioners taking protective measures for battered women. I have shown that the daily routines of the legal system are linked to ideological ways of interpreting women's lives and extended relations of social ruling. I have proposed conducting an interagency safety audit as a legal reform strategy which can identify concrete ways to insert victim safety into domestic-assault case management procedures.
\end{abstract}




\section{CHAPTER ONE}

\section{THE PROJECT}

"Re-vision-the act of looking back, of seeing with fresh eyes, the entering of old text from a new" critical direction-is for women more than a chapter in cultural history: it is an act of survival." (Adrienne Rich, 1979, p. 35)

\section{Introduction}

The purpose of this project is twofold. My first objective is to propose a shift in the legal advocacy approaches employed by activists in the U.S. battered women's movement. I have used Dorothy Smith's work on institutional ethnography to explicate how practices and procedures used in the daily work routines of criminal justice professionals such as police officers, probation officers, judges, and prosecutors limit the likelihood that court involvement will result in interventions which centralize victim safety as a case outcome. I have proposed a method of engaging criminal justice professionals and community advocates ${ }^{1}$ in an investigation of local criminal justice settings with the intent of making changes in practices which fail to attend to the safety needs of women who are battered. My focus has been on explicating the work of practitioners in the police and court system that is not observable to advocates in the courtroom, work that produces institutional accounts of women's experience which erases the violence and intimidation battered women face in their intimate relationships. I have focused, although surely not as ingeniously as Smith would have, on the specific ways that texts such as administrative forms, regulations, reports to the court, and legal arguments are the instruments of power in this system and therefore logically objects of an advocate's inquiry (D. E. Smith, 1990b). As an activist I have also been cognizant in my investigation of textually mediated practices that these practices occur in an institution with certain defining features that must be accounted for in change strategies. A woman's safety is contingent on the ability to address the specifics of her situation and requires a recognition of the danger she faces (Browne, 1987; Jones, 1980).

\footnotetext{
'In many states in the U.S. a worker in the battered women's movement is called an advocate, meaning a person called to one's aid. I will use the terms advocate and activist interchangeably throughout this work.
} 
The danger a battered woman faces is linked to what her abuser is able and willing to do to her. Yet in the processing of criminal cases, there is no systematized method of gathering this information. The process is incident focused and driven by the goal of conviction. "What is going on" is not as important as "what happened." Danger also relates to how the power differential between the man who batters and the woman who is beaten plays out in their everyday lives. My investigation explicates the role of both textual practices and key structural features of the criminal justice system in compromising women's safety.

My second objective is to develop the concept of a community audit as a local application of Smith's work on institutional ethnography (1987). Such an audit offers a method of community inquiry and institutional reform that I believe is applicable to other feminist projects beyond this institution (the legal system), and beyond this issue (violence in intimate relationships). Institutional relations are global. They are generalizers and representations of local/individual social relationships. As Smith notes, "The language of the everyday world as it is incorporated into the descriptions of that world is rooted in social relations beyond it and expresses relations not peculiar to the particular setting it describes" (D. E. Smith, 1987, p. 156). Thus, my analysis of only one institution may be representative of all the institutions with which battered women come into contact. The audit process I have proposed compels a community to address the way victim safety is compromised by both the ideological practices embedded in the current legal response and the fragmented processing of these cases.

I conducted my field work for this study in Duluth, Minnesota, over the two-year period following my graduate work at the Ontario Institute for Studies in Education (OISE). I had been working in Duluth since 1980 on a legal advocacy project which has gained international attention for its innovative approach to coordinating various government agencies responsible for processing criminal and civil court cases involving domestic violence (Pence, 1988). Prior to my move to Duluth I had been active in organizing the first battered women's shelter in Minneapolis and had worked with a group of activists to lobby for legal reforms.

In 1975, every advocate for battered women in Minnesota met in the upstairs office of Women 's Advocates, the only battered women's shelter in the state. We could very likely have fit every 
advocate in the country in a slightly larger room. For many of the feminists in the emerging movement, this time was filled with excitement and the sense of radical possibilities. In chapters 2 and 3 I describe how legal advocacy projects such as the one that I worked for, the Domestic Abuse Intervention Project, emerged from the shelter movement of the ea-ly 1970s. This description is shaped by my history in the movement and particularly by my history in organizing a legal advocacy project. The meetings, debates, fights, experiments, failures, and successes that I have experienced or witnessed provide a powerful frame through which I interpret and organize a description of legal advocacy projects in the U.S. Another activist from another position in the movement, with a different political commitment and a different social history, would tell a very different story. This project has been a journey as I have sought answers to the questions that I imagine all single-issue activists like me eventually stop to ask: Has it all been worth it? Have I spent 20 years on the wrong track? What should I do next?

My time at OISE has provided me with a method to answer these questions and has in fact also led to some unexpected solutions. When I came to OISE I was disenchanted with the battered women's movement. I could see we had lost our subversive edge. It seemed the vitality of the movement was dwindling. Certainly my sense of its radical political possibility was waning. I was working long hours and was still committed to the issue, but I couldn't see where we were going. We had changed the laws, we had changed the public belief that battering was a private matter, we had on some level criminalized this practice that had for centuries been normalized as a husband's right and duty. But all of that happened in the first decade of the movement. The second decade seemed to be taken up with holding onto the gains, fighting off the attacks by men's rights groups, endlessly training court practitioners on changes in the law, and arguing with professionals about the causes of men's violence toward their lovers, wives, or partners.

My intent in going to graduate school was to earn a Ph.D., leave the battered women's movement, find a teaching position, and discover a new way of being political. I wanted my dissertation to be everything I learned in the battered women's movement, sort of a "goodbye" think piece. I must not have anticipated learning anything new to write about or think about or work on. I felt like a mathematician who labors on a problem for years and solves all sorts of its aspects but never quite works out the final equation. I was stuck. My discussions with friends in 
the movement led me to believe that we were collectively stuck. I decided that graduate school would help me find out how and where to move politically with this issue.

Before I left Duluth for Toronto I had collected dozens of letters that batterers had written their partners after beating them. They ranged from windshield notes ("Fuck you bitch your dead") to cards sent with flowers ("I'll never forget. . . if you'll just forgive") to long mind-boggling rationalizations for the abuse. Each letter was going to be a lead-in to a chapter in my dissertation about how men who batter exercise power over their wives, lovers, and children. It would have been (and still someday will be) an interesting read, a very popular item among sheiter residents, and a fairly easy book to write. Somehow all of that changed at OISE. It changed with my first courses, courses that stimulated not my thinking about the pile of letters that I had lugged with me from Minnesota, but about the work that I had done over the past 20 years. I found myself thinking, "If I had only read this earlier," and, "If I had only thought about that before working on mandatory arrest legislation."

After the first two sessions I came home for 3 months and threw myself full force back into my job, but I could see that I was bringing a different way of thinking to my work. My co-workers were not impressed with the comments and questions I raised at meetings. They all noticed that I was "talking different," using words that were not part of our collective language, but not necessarily that I was thinking any more clearly.

I started to notice changes that were not simply superficial. I was actually looking at things differently and looking at different things. I started to ask more frequently, how is it that this is happening, and less frequently, why is it happening. I started to find court workers' practices more interesting than their attitudes or beliefs. Most important I started to understand what I was hearing at OISE. I could actually see how knowledge was manufactured. I understood more about the concept of multiple subjectivities and what that meant in terms of mandatory arrest or pro-prosecution policies. But I lacked the understanding or ability to articulate what I was seeing to my co-workers.

It was through my gradual understanding of D. E. Smith's work on institutional ethnography that 
I was able to link my work to my growing understanding of how power worked in women's lives and of how institutional ways of governing and managing were actively shaping the possibilities for protection of women who turn to the legal system when being battered. Choosing her work was not so much the result of a careful examination of the many alternative research methods as it was a commitment to the political possibilities that her method of ethnographic studies offers activists like myself. It was simply a matter of usefulness. The domestic violence (the U.S. term for woman abuse) field in the U.S. has been littered with thousands of control group studies. But these studies rarely help activists like myself answer our most pressing question, "Whai should we do next?" I chose ethnomethodology-specifically, ethnomethodology as formulated by D.E. Smith-because I could see the possibility it offered in mapping out a strategy for deepening the institutional advocacy work of the project I was involved with and of many others in the U.S. Whether I remained in the work or moved on, I wanted to be part of thinking through the future.

Ethnomethodology is a recent theoretical approach that analyzes how individuals in any social situation interact with each other and interpret these interactions. That is, how (process) do individuals "know" or construct the knowledge of norms from their social interactions. These interpretations, rather than preordained rules, construct their reality. Harold Garfinkel (1967) elaborated and utilized ethnomethodology as a way of understanding how individuals together accomplish what becomes then normative reality. His "breaching" experiments" indicate how fragile social orders and rules are. Garfinkel argues that the everyday interactions/activities of individuals are formed, named, and interpreted as activities during the processes of accounting, relating, and naming. Weeks (1990) maintains that

\footnotetext{
'These experiments involve breaching nomative rules of behavior to indicate the extent of our dependency on common and implicitly agreed-upon knowledge to carty on social interactions. For example, Garfinkel's students would answer simple questions from others such as "How are you?" with unexpected questions such as "What do you mean?" "In regards to what-spiritual, physical, emotional well-being?" The person asking would tend to get extremely angry and disconcerted at such a breach of common understandings. Of course, ethnomethodology is used to uncover not the background rules, but the processes involved in creating these rules.

One might expect that if all order, individual and institutional, is fragile, as its existence depends on common knowledge, then it is vulnerable to change by responses that are atypical; violating or challenging the agreed-upon rules of interactions, however subtly, could actually change the situation or institution. It seems, however, that reality contradicts this. People have been giving atypical responses forever (e.g., immigrants, gays and lesbians, and other marginalized groups), quite unsuccessfully:
} 
Ethnomethodology inquires into the methods whereby we, as members of a society or community, organize our activities so that we, as well as sociologists, come to recognize the patterns that we think of as social structures." (p. 181)

Thus, rather than accepting everyday activities and occurrences as "natural," we can use ethnomethodology to problematize them as "not natural" and understand the rules (including commonsense reasoning and background information) that underlie these events, interactions, and occurrences.

In the same manner, we can question the irrefutability of institutions, official papers, and rules and unveil societal hierarchies. The ideological practices that order these hierarchies are also important to analyze. D. E. Smith has developed a way of analyzing people's everyday working lives within an institution: the way they are organized to work produces the reality of that institution, which in turn shapes the everyday world of women whose lives are managed by institutions of social control, such as the law.

Workers in the court system engage in practices which continually reproduce the law as an institution. Racism, sexism, and inattentiveness to women's safety occurs when people behave and interact in certain ways. Thus, a goal of an ethnomethodological investigation is to challenge structures as natural givens and expose them as individual interactions and experiences. Changing the interactions (processes) could result in change in the institution itself.

Most of the research in the field of domestic violence is rooted in the research method of the physical sciences, producing study after study of controlled experiments in which authors claim to locate a determinant of the system's failure to adequately protect women (National Clearinghouse for the Defense of Battered Women, 1995). More often, however, they produce profiles of women who are battered and of men who batter and address the implications of these profiles to the kind of interventions and services that should be offered by the state (Ford, 1991; Saunders, 1992; Sherman \& Berk, 1984). These studies begin in the already abstracted institutional version of the world. As D. E. Smith maintains throughout her work, the sociologist uses conceptual practices that are parallel to the institutions they purport to objectively describe and analyze. These practices always fall short of telling us how activities are organized at the 
local level and articulated to larger social relations of ruling, an understanding necessary to organize an advocacy strategy that produces fundamental change.

Much current social science research and most well-funded research translates women's lived experiences into categories and typifications that discard their actual experiences and transport women into the same discursive world that the legal system employs to make them institutionally actionable. Women are identified in institutional terms. For example, a woman may be "the recanting witness." This term says nothing of her experience. In chapter 4 I quote from an interview with a woman who is charged with filing a false police report when she recants her original statement to the police. The term recanting says nothing of the threats, the role of the defense attorney in obtaining her recanting statement, or the 11 -month delay between the assault and the court's action in the case. It obscures the social relations which shape her everyday life. yet sociologists use the legal institution's renderings as fact. What occurred to produce the recanting statement is not available to the court, the jury, the sociologist.

The failure of sociologists to escape the conceptual practices of the ruling apparatus has in practice left the psychologist telling us about women who get battered, the criminologist about men who batter, and the legal theorist about the efficacy of different legal approaches and working with different types of criminals and victims. The gaze is a one-way gaze. The woman who is the object of that gaze is a source of information but not of knowledge. She is never allowed to return the gaze. She is, as Shamita Das Dasgupta (interview, June 17, 1996) says, "an abola," a creature who can not speak.

We have a word for creatures who have no voice, no voice in that they cannot speak a language understandable to us. It is abola. So women who are not allowed to speak, by their husbands or by institutions or because of violence, are abola.

Examining women's experiences by beginning with the abstract notions of the battered woman. the hostile witness, the victim, and the at-risk mother, or looking to contextualize certain behavior such as "failing to protect," "recanting," or "returning to the abuser," is the grist of the social science research mill in this field. Feminists often enter into a similar commitment to 
documenting or debunking these ideologically produced representations of the social world by using the same discursive practices but shifting the focus of the gaze from the victim to the offender or to the intervening professional. Feminist and pro-feminist studies frequently expose victim blaming in the mental health paradigms (Mann, 1986), gender bias in policing (Edwards, 1989), forms of collusion by therapists with batterers (Adams, 1988), and abuse of institutional authority by judges, social workers, police officers, probation officers, or others in the system (Buzawa \& Buzawa, 1990). While these studies may present public policy implications or provide groups advocating for certain judicial appointments with "hard data" to raise the points they need to block a poor appointment, they still lock us into the parameters established by institutionally authorized ways of knowing. As C. Wright Mills (1967) notes of these types of controlled experiments in the social sciences,

On the purely molecular level there is a connection proved between problematic observation and explanatory observation, yet here the larger implications and meaning of that association are neither explored nor explained. When you are unsatisfied with such work it is because, although it is "neat" and "ingenious," you feel there is "more to it all." (p. 562)

In the past five years many ethnographic studies and qualitative projects have held onto the situated subject-in this case, women who are beaten-and have insisted on a project which begins from their standpoint. The work of James Ptacek (1995), Wittner (in press), and Beth Richie (1985) are just a few examples. Ethnographic studies and other forms of research can be limited in their value to activists wishing to effect change on a national or state level because such studies are generally tied to the particulars of a local setting in which the observation and interviews occurred or because they produce information about the individual choices and characteristics of the actors involved.

D. E. Smith's notion of an institutional ethnography offers us a way out of this trap. She uses a method which intends to explicate the institutional relations which shape the everyday world. This method allows a way for us to see how a woman who is beaten by her husband is made institutionally actionable and how in that process attention to her safety drops away as other institutional objectives subsume her particular situation and needs under a generalized way of "handling assaults." In the courtroom the fact that the processing of the case often compromises 
a woman's safety, or even increases the danger to her, is seen as the result of her situation and not as linked to how social relations are accomplished in the methods of institutional involvement in these cases (Browne, 1987; Campbell, 1995; Jones, 1980). The institutional function - in this case the law-has specific ways of bringing individuals out of their everyday world, with its actual contingencies, into institutional existence as crime victims. Smith's work offers a way to attend to the local and the particulars of a case in order to provide activists with a means of grasping the social relations which organize the everyday world of women who are battered. Thus while a case is tied to the particulars of a given woman's experience, its exploration uncovers the institutional relations which act as determinants of her everyday world I am looking specifically at how those institutional relations take up and attend to the safety of women who are battered.

\section{The Project}

In the years I have worked in the battered women movement, I have watched more than 200 sentencing hearings for men who have assaulted their partners. The first time I observed such a hearing after being away from the courthouse for almost 2 years, I was struck by how sanitized it all seemed. There was no mention of the violence, of the blows, of the kicks to the ribs, no mention of what it must have felt like for the woman when her body hit the concrete, no mention of her fear, her pain, her anger, or of how this attack affected her life. The probation officer's report seemed to be more of a character reference than a sentencing recommendation for a man who had brutally beaten his partner. When I returned to the office I read the police report on the incident. According to this report, the defendant had smashed his partner's head into a wall eight times and kicked her down a flight of stairs. She had multiple bruises, lacerations, and a sprained wrist.

The probation officer had reported on where the defendant worked, his military service record, his income, even his volunteer activities. As I watched this probation officer doing his job I thought, "Will this guy ever get it?" The probation officer was a nice man. I genuinely liked him, but it didn't seem to matter how many trainings he had gone to or how many pleasant chats we had had in the hallways-he just didn't appear to care about what had happened to the woman this man had beaten. As a woman's advocate, I felt frustrated, but I didn't really know 
how to make the woman count.

In the next chapters I want to re-vision my work as an activist working for reforms in the legal system's responses to women. I am basing this re-visioning on investigations and organizing work I conducted from 1992 to 1996 . As I applied what I was understanding from D. E. Smith's work, particularly seeing texts as the medium of power in institutional practices of ruling, I was able to discern previously hidden barriers to the goal of centralizing women's safety in the cour process. These barriers materialize in work routines, administrative processes, the formation of public policy and law, legal ways of knowing things, and the structural features that characterize the legal system and its relationship to other institutional modes of ruling, particularly the social welfare and mental health apparatuses (D. E. Smith, 1987).

By turning my attention away from individuals in the system, whom I had seen as the problem to be fixed, and watching instead the daily routines and everyday practices in which they engage, I began to see quite differently the problem of making women count. I came to see that the very processes and ways of knowing that excluded women from being active subjects in the resolution of their cases simultaneously constrained practitioners from acting outside of institutionally mandated boundaries of functioning and thinking. I began my investigation at the level of everyday practice. It has been somewhat like examining a Russian nesting doll, in which one wooden doll encases another, which encases another, until one finally reaches the first doll, or is it the last? They are all painted in the same colors, wearing the same clothes, and smiling the same smile. The individual practitioner's work routine is encased in a system's work routine, which like that of individual workers has definite features. That system is encased in the institution of the law, which carries its corollary features, and the law is encased in a web of institutions which make up a complex social apparatus of ruling. Within this web are intersecting discourses, fields of knowledge, and ways of ruling encompassing the medical, mental health, and social welfare institutions and professions. Like the Russian doll, the smallest procedure mirrors the largest, and the largest encompasses layers of similarly constructed processes, yet each stands separate from the whole.

Following chapters 2 and 3 on the legal advocacy history of the battered women's movement, I 
describe my investigation, beginning with a discussion of how individuals' daily work routines are organized. I have focused my discussion on how routines are organized to collect, produce, and disseminate information about cases in ways which impact the safety of women who are the victims of the crimes processed in the criminal court system. ${ }^{3}$ I have shown how these routines are encased in a legal system characterized by certain features particularly problematic when it processes domestic assault cases. These features include (1) case orientation and textual mediation; (2) a highly specialized labor force with a fragmented case-processing structure; (3) a focus on an incident rather than on the overall way the abuser uses violence in the relationship, and (4) use of an adversarial process in which one side wins and the other loses.

The processes which make up the system are encased in a larger web of institutional practices of ruling. When the criminal court process culminates in a sentencing hearing, the woman's experience of violence has all but disappeared from the case. It has been systematized, replaced, and remade into legal equations and operations that bear little resemblance to the woman's experience but enter into and organize her life and fail to challenge the relations under which she is compelled to live. The state's action looks objective and relevant to those who process the case but not to the citizen most harmed by the violence. I want to draw attention both to how practitioners are organized to perform their individual tasks and to the features characterizing the criminal court structure. It is this organization of tasks and these features which work together to produce accounts of violent events which consistently marginalizes attention to the safety of victims. Unless women's safety is built into the processing of a case at each point, the legal system will remain a woefully inadequate source of protection for battered women and their children. ${ }^{4}$

\footnotetext{
${ }^{3}$ I will also refer to civil protection order cases. In Minnesota many of these cases are simultaneously processed in criminal court and civil court. The civil court can issue an order limiting an abuser's contact with the person who has been abused. The court has broad powers to issue reliefs that are intended to protect the victim from domestic violence, such as counseling for the abuser, an order to surrender weapons, and limited or supervised visitation of children.

II am of course aware of the use of violence by women against men in personal relationships. This study does not attempt to examine safety from a gender-neutral perspective. The legal response is highly gendered, as is the way in which men and women use violence in relationships. I am focusing here on cases in which women are the victims: however, the same documentary practices apply to cases involving men as victims.
} 
I cannot pretend that my investigation has taken a neat and orderly path. I have taken many side excursions. Eventually, however, it has led me to produce a blueprint for a similar but more comprehensive investigation of local criminal and civil court processing of domestic assault cases. In chapters 8 and 9 I propose a method of investigating or auditing the attentiveness of the criminal court system to providing ongoing protection for battered women as it processes the cases against their partners. The City of Duluth was recently awarded a federal grant to complete such an audit of the Duluth court system. An audit is best conducted by a team of practitioners and community advocates in search of a better way to do things, not by someone who does not work with these cases on a daily basis. The means, after all, is the goal in practice. In this project I provide a description of that audit process.

Site of the Study

Duluth, Minnesota, is the primary site of my study. Duluth is a mostly working-class city of 85,500 people and is located in the state's Sixth Judicial District. . According to U.S. Census Bureau statistics, the annual income of fifty-two percent of its households is less than $\$ 25,000$; only sixteen percent have annual income of $\$ 50,000$ or greater. The population is $2 \%$ Native American, 1\% Asian American, 1\% African American, and 96\% European American.

There are two battered women's advocacy programs in Duluth, the Women's Coalition and the Domestic Abuse Intervention Project (DAIP). The Women's Coalition provides battered women shelter, educational groups, and advocacy in the civil and criminal court. The shelter advocates conduct in essence almost all of the individual advocacy for battered women and in so doing become the central informants in the process of determining institutional advocacy goals. The $\mathrm{DAIP}$, like the shelter, is a small nonprofit agency, but its orientation is not direct advocacy in individual cases for battered women. It acts instead as a monitoring or coordinating organization for all the agencies and practitioners who intervene in these cases. It is an outsider organization which has through its history established some insider rights. The DAIP staff fill gaps in the system's handling of domestic assault cases by bringing about various interagency meetings and dialogues around particular problems in the system, identifying the ongoing training needs of practitioners in the community, coordinating those trainings, coordinating an interagency rehabilitation program, and operating a case-tracking system. This tracking system informs 
practitioners of changes in cases, monitors practitioners' compliance with agreed-upon policies, and monitors compliance of individual offenders with court orders. I am including some background information on these two community-based organizations to place our local work into a broader national picture and to contextualize a later discussion about making changes in the Duluth system.

\section{The Women's Coalition}

Every shelter has its birthplace and its birth story. Some center on a tragedy, often a woman's murder; others are entwined with the history of activists in the women's movement. In Duluth, the story begins in the private lives of three women who met at a community mental health center while participating in a counseling group for "women in transition." This was a common euphemism in the seventies for women in the process of separation or divorce. The group had been meeting for four or five sessions when the topic of fair fighting came up. One of the members mentioned that her boyfriend had hit her that week because she called him a name. Another responded by talking about her husband's "temper" and the third lent support by talking about the difficulties of practicing communication skills with a partner who ends more arguments with a slap than an insult. At the end of the session the therapist told the three women that she had just read about a shelter for battered women opening in St. Paul. As one of the women recounts the story,

She [the therapist] wasn't suggesting that we pack up and head south for this haven of safety as much as she was telling us that what we were experiencing was not so unusual. She used this term "battered women," although I didn't really think it was meant for someone in my situation, I did know that I had something in common with those women. I know Jean and Pat did too, because after the group all three of us hung around the parking lot smoking and ever so carefully testing how much of what was happening in our lives was safe to talk about. This post-group parking lot kibitzing went on for another two or three sessions. We finally moved it to Perkins [a local pancake house] where the first mention of us actually trying to open a shelter in Duluth was raised. Peg [the therapist] put us in touch with some women in town who had started other women's programs and we were off. To this day, if you ask the early organizers where did the idea of a shelter originate, we'd all answer unanimously, Perkins. We didn't have an office, so we held our meetings there for the first year. We probably drank a thousand cups of coffee and ate at least that many pancakes. (Interview, June 18, 1995)

While it seems unfair, I will now summarize literally thousands of hours of work in two overly 
long sentences. This gang of three women sought out help from women who had opened a health clinic and a rape crisis center; conducted a needs assessment by calling every agency director in town and interviewing them about what, if anything, they were doing to help battered women; recorded their inadequate answers and wrote them up in the form of an official report; sepirated from their partners and went on welfare; and hooked into the new call-forwarding technology that let them operate a twenty-four-hour hot-line from their home phones. They advertised a support group for women in abusive relationships; turned that group into an organizing committee, complete with subcommittees, to start a shelter; incorporated; went to the press with their needs assessment results; received a $\$ 10,000$ grant from the county to offer services to battered women; and talked the housing authority into renting them a duplex for $\$ 1$ a year. ${ }^{5}$

By 1979, the Duluth shelter staff, like that of other sheiters in the state, was becoming increasingly frustrated with how new laws were being implemented and with the lack of progress in securing more substantive changes in both the police and court systems' response to battered women and their intervention with batterers. Therapy groups for men were starting to form and there was a growing concern that these groups would give an already unresponsive system a way to further decriminalize these cases. Nationally, shelter activists were advocating for increased involvement and intervention by the courts and the police and an end to the nearly laissez-faire approach that dominated police and court response.

In Minnesota several activists met to discuss a proposal to attempt to organize a battered women's institutional advocacy project. The notion of locating a city in which to test many of the assumptions that advocates were making about how to better protect women emerged from a series of statewide meetings of shelter workers. The similarities in the problems that women using shelters were experiencing with police, prosecutors, and judges were striking, but the resources to work simultaneously on more than 600 Minnesota law enforcement agencies and 11 judicial districts were not available. We thought if we could make headway in one jurisdiction it would clear a path for advocacy in all of them. Because of the size of Duluth, the shelter staff's enthusiasm for working on such an effort, and the willingness of a few key people, such as the

\footnotetext{
'I know this history because I worked as the Minnesota State Director of Programs for Battered Women from 1977 to 1980. During that time I worked extensively with the women organizing the shelter in Duluth.
} 
police chief and the city attorney, to experiment with new policies, Duluth was selected as the site of the demonstration project (Pence, 1983).

\section{The Domestic Abuse Intervention Project}

Before selecting Duluth as the project site, organizers met with the administrators of the police department, the heads of the city and county prosecutors' offices, the directors of three mental health agencies, the deputy in charge of the county jail, and the chief judge. A vague proposal was put forward, asking that each agency attempt to reduce repeat cases of domestic assaults by developing written policies and protocols and engaging in an interagency networking process. Each administrator agreed contingent on the agreement of the others. This non-specific commitment to developing policies was enough for project organizers to decide to locate the project in Duluth. A Duluth foundation made the first grant to the project of $\$ 30,000$, and in September of 1980, 4 years after the opening of the shelter, the Domestic Abuse Intervention Project (DAIP) opened its office (Pence, 1996).

The first DAIP staff consisted of a legal advocate from the shelter, a secretary who had been volunteering at the shelter, and me, an activist from Minneapolis who had been administering state shelter funds. All of the planning and strategizing was conducted with DAIP and shelter staff. DAIP staff contacted one person from each law enforcement and court agency whom shelter advocates had identified as friendly to the cause of making changes in the system. These practitioners provided staff with an insider's knowledge of how the system worked as well as political advice on how to accomplish the goals of the project. At the same time, project organizers were holding evening meetings with women who had used the shelter to find out how the system worked in practice and how it worked for different women. Proposed policies and procedures originated at these meetings. By the time project organizers met with agency administrators, they had a fairly good picture of how the system was designed to work, how it was actually working, what changes in institutional procedures advocates wanted to propose, and who would be sympathetic to these proposals, as well as who might be hostile or resistant.

Nine agencies were drawn into the negotiating process, although project organizers avoided suggesting any interagency meetings until after the basics of a policy or procedural agreement 
had been worked out with each agency. Once the decision was made to try the plan out in Duluth, it took 9 months to enact the policies. On March l, 1981, at 2:00 p.m., the agency directors participated in a press conference to announce their new policies, which then immediately went into effect.

The role of the DAIP in orchestrating this interagency experiment and then working with individual agencies to coordinate its ongoing implementation has positioned this communitybased organization in an unusual insider-outsider role. The relationship of the DAIP to these agencies and my role as one of the central figures in the DAIP efforts has allowed me in my position as a graduate student to have relatively unfettered access to practitioners, files, and assistance that could not be easily secured by another ethnographer. I address this issue in chapter 9 in my proposal for an interagency-sponsored audit of the system.

\section{Sources of Data}

I have used five sources of data during my investigation: observation of practitioners, interviews with practitioners and advocates, notes from meetings with practitioners in the criminal justice system, review of case files and court records, and published literature. Most of these interviews. observations, and court documents were related to cases within the Duluth court system. I have, however, used interviews with some practitioners outside the Duluth area as well as several documents I secured in doing work on cases outside the Duluth system.

Duluth is a small community. Some of the people whom I interviewed had absolutely no qualms about me using their names and their identities, while others were quite concerned that their statements not be in any way attributable to them. I have therefore attempted to provide some anonymity to these informants by omitting their names and changing their identifying features. With the exception of the sentencing hearing in Baltimore appearing in chapter 7, I have changed names, dates, and identities of people in all of the documents I have used. I have likewise changed identifying features of cases without changing the important aspects of the texts I am exploring in this study.

When I began this project I set up appointments to interview a number of practitioners. I 
recorded and transcribed these interviews and used materials from them in developing my analysis. As time went on, I spent more time in the court system observing, meeting, and talking informally with practitioners. I also spent time talking with people before and after the advocacy meetings I was involved in. Many of the quotes and much of the information that $I$ have drawn on came from practitioners under these circumstances. I have also quoted from battered women with whom I have talked during the past several years and from a number of advocates who themselves have been battered.

None of the meetings and informal conversations discussed above were recorded. I took notes afterwards, and many of the quotes in this dissertation are my best efforts at remembering what someone had said 2 or 3 hours earlier. These quotes are therefore missing the "ums" and "ahs" of informal speech.

I made observations and secured documents for analysis over a $21 / 2$-year period, from May of 1994 through September of 1996. During that time, I had access to all of the police reports regarding domestic assaults filed in the past 7 years in the city of Duluth; all of the affidavits for protection orders; a limited number of sentencing transcripts; and all of the court case files on misdemeanor and felony cases in the Sixth Judicial District. I observed practitioners carrying out the following procedures: (a) 911 dispatching procedures; (b) police responses to domestic assault calls; (c) police report-writing procedures; (d) booking procedures of the St. Louis County jail; (e) arraignment court procedures; (f) supervised release interviews with offenders and presentations to the court; (g) order for protection hearings; (h) presentence investigations and presentations to the court; (i) pretrial hearings; (j) trials; (k) sentencing hearings; and (l) intake procedures for offenders court ordered to a batterers' program.

I also interviewed 32 practitioners in the criminal and civil court system, 11 advocates, and 6 battered women. I obtained complete court files on 6 cases and reviewed 207 police reports, 9 transcripts of sentencing hearings, and 14 detention order files. I chose the cases that I followed through the system simply by listening for names that shelter advocates mentioned during meetings with DAIP staff, or names that I heard at meetings with the police department or in discussions with the city attorney's office. For example, if an advocate brought up a case in 
which one of the people arrested was released from jail without any kind of assessment done of his dangerousness, I would follow up on it because it is a typical advocacy case in our system.

Because I am focusing on the way texts organize the everyday practices of ordinary practitioners, I have chosen not to use any poorly written police reports, or describe any practitioners' actions that seem to be out of the ordinary. The everyday world is problematic enough as it is. 


\section{CHAPTER TWO}

\section{LEGAL ADVOCACY AND THE BATTERED WOMEN'S MOVEMENT}

In the past 20 years activists in the U.S. battered women's movement have successfully argued that the state has an obligation to intervene in personal relationships in order to protect women from their abusive partners, that it can and should remove violent husbands from their private homes in order to protect women in their private homes, that the police should arrest husbands for assault, and that the state should prosecute them (Dobash \& Dobash, 1979; Schechter, 1982). These shifts in the legal status of women marked a monumental achievement for the women's movement, not unlike the gains in the abortion and divorce rights efforts.

None of the new measures was implemented as a matter of course. In every state, in every courthouse, and in every squad car, there has been resistance to the full measure of what this social movement seeks to gain for women. Still, for the first time in the history of the struggle against "wife beating" that began as early as 1640, the contemporary battered women's movement has won public acknowledgment that the state has the obligation to render full protection to abused women (Dobash \& Dobash, 1979; Pleck, 1989).

Every state has expanded the obligation and authority of police to arrest abusive partners. Every state has passed some version of a protection order that allows the court to exclude abusive partners from their homes. The National Council of Family and Juvenile Court Judges has published an extensive model state code recommending that state lawmakers adopt a comprehensive legislative approach to the reform of the antiquated legal system (National Council of Juvenile and Family Court Judges, 1994). The American Medical Association and the American Bar Association, two of the most powerful professional lobbies in Washington, D.C., have both adopted far-reaching positions on domestic violence (Flitcraft, 1992). Public opinion, though far from fully enlightened, has dramatically changed as court watch groups, community-based legal advocacy projects, and battered women's shelters have put the spotlight on practitioners, their failures to respond to "domestic violence," and the ways abusers escape social sanction. Men who beat their partners can no longer expect to use violence and remain immune from social sanction, nor can practitioners who fail to respond to the violence be assured 
of anonymity. ${ }^{6}$

The suffrage and progressive social reform movements of the late nineteenth century produced legislative changes ending over 200 years of regulating wife beating and criminalized the practice regardless of the woman's behavior. By 1911, laws forbidding wife beating had been passed in every state. Because no infrastructure of local efforts existed to advocate for the implementation of the new laws, they were noted in law books and shelved until 70 years later, when the next wave of feminism gained momentum and activists insisted on their enforcement (Dobash \& Dobash, 1979; Pleck, 1989).

In the U.S. the battered women's movement emerged in the middle 1970s on the heels of the social activism of the 1960 s. I was motivated by the challenges of the most recent wave of feminism. It attracted people of diverse political commitments to advocate for women's right to freedom from violence in marriages. It has been a pragmatic movement which in its early years drew much of its strategy from the progressive social struggles of the sixties and much of its theory from the feminist movement. In the early seventies, when the first shelters opened, the feminist movement was organizing largely through locally based consciousness-raising groups. From these groups rose a voice of and for women that had been absent in the public discourse for half a century. As the women's movement developed its political analysis, it called into question the European notion of the "natural family unit" held together by love. Feminists argued that the nuclear family, which evolved over centuries of European patriarchal feudalism and capitalism, was held together not so much by love as by the concrete conditions of women's subordinate economic and social status in the public and private spheres (Schechter, 1982).

The early days of the contemporary wave of feminism were characterized by women organizing in their local communities to dismantle some small piece of this overwhelming patriarchal apparatus, so huge and so all-encompassing that common sense dictated finding just a piece of it

\footnotetext{
'For example, a controversy recently surrounded Brooklyn Criminal Coun Judge Lorin Duckman. Both New: York Govemor George Pataki and New York City Mayor Rudolph Giuliani sought the judge's removal for refusing to believe that domestic violence is a crime (March 18,96, Speaking $U_{P}$ ). This high-level reaction to a judge s action on a domestic assault case would have been unheard of 20 years ago.
} 
that could be changed. Activists often refer to their work as chipping away at the patriarchy. Many activists believed that challenging the legal and social tolerance of men's violence against women would be a critical step in undermining men's social power over women. Feminists organized around specific forms of male violence toward women. Some went about changing the laws that made it difficult to prosecute men who rape strangers and impossible to prosecute men who rape their wives. Native American women fought the removal of their children from their communities by social workers. Some women struggled for abortion rights. Others exposed the racist practices of forced sterilization. There were those who took on the multibillion-dollar pornography and prostitution industries that promoted pornography as free speech and prostitution as a victimless crime. Still others challenged the de facto right of husbands to beat their wives without legal sanction. Across the country rape crisis centers, anti-pornography projects, abortion clinics, women's health centers, and shelters for battered women began to open.

All these projects were in some way anchored in the women's liberation movement. While there was no central organization that activists all joined, no party or national office, themes that came directly from the rhetoric of the women's movement could be found in all of this work (Freeman, 1975). One theme had to do with a growing awareness of the systemic nature of women's collective oppression and was expressed in the popular slogan "The personal is the political and the political is personal."

Woman's liberation is the first radical movement to base its politics-in fact, create its politics - out of concrete personal experiences. We've learned that those experiences are not our private hang-ups. They are shared by every woman, and are therefore political. The theory, then, comes out of a human feeling, not out of textbook rhetoric. (Morgan, 1970, p. $\mathrm{xx}$ )

A second theme had to do with the notion of making visible the invisible and of women finding their voices. In all of this work there was a recognition of the importance of women speaking out about our experiences, about rape, about botched back-alley abortions, about poverty, about beatings at the hands of our lovers, pimps, and husbands. "Speaking out" meant women sharing actual experiences. This challenged the authority of priests, doctors, lawyers, psychiatrists, 
retailers, reporters, tribal leaders, politicians, parents, heads of families, community leaders, and teachers, all of whose daily practices silenced women's voices and rendered their abuse and oppression invisible. ${ }^{7}$

However, although it is important to recognize the connection of the battered women's movement to feminist activism and theory, a claim that shelters were largely organized by women who identified as feminists or saw themselves as part of the women's movement would be inaccurate. Many of the women who organized the first shelters came to this work as seasoned activists in the civil rights movement, the welfare rights movement of the Nixon era, the anti-war movement, Native American struggles for treaty rights, and various struggles to liberalize religious institutions. For many of these women the emerging feminist analysis was too narrow to encompass the diverse experiences of women of differing class, ethnic, and social origins. For others this work was their first involvement with social activism. They may have come because of the murder of a daughter, sister, or mother, or because they were being battered or had lived with violence in the past. Many joined the work to create different possibilities for their daughters (Schechter, 1982).

The battered women's movement did not develop a radical critique of the family or of the capitalist state or of heterosexism. Rather, safety became to the battered women's movement what liberation was to radical feminism. This means that the battered women's movement is not a feminist project the way the anti-pornography, the anti-prostitution, or abortion rights movements have been. It cannot be adequately understood or critiqued unless we account for its political diversity and its corresponding absence of a radical critique. This was an undertaking in which feminists and progressives played a primary role but were not the sole or even perhaps the majority of workers. Of course, political positions can change. As one shelter-resident-turnedactivist remarked, "I never considered myself a political person or a feminist, but then there is nothing more politicizing than a fist in the face followed by a little chat with ten other women with black eyes" (interview, May 19, 1995).

\footnotetext{
'Of course there is also work by many feminists exploring the power in silence, e.g., the 1983 Marleen Gorris film A Question of Silence.
} 
Women became politicized as we sought to understand both our differences and our common ground. African American women sought to explicate how the history of slavery, institutional racism, poverty, and Western forms of sexism shape African American family structures and power relations between women and men (Coley \& Beckett, 1988; hooks, 1981, 1984; B. Smith, 1983). Native American women analyzed how the legacy of forced assimilation through boarding schools, foster care, adoption, laws restricting the practice of spiritual traditions, and a host of government policies gave rise to the widespread use of violence by Native American men against their partners, a practice which was not widespread in pre-colonial America (Bachman, 1992; Chester et al, 1994; Leacock, 1994). Parallel critiques were developed by women of European descent, Asian American women, Latinas, and immigrant women. ${ }^{8}$ Yet while these critiques were developed simultaneously with those of Western white feminists, the latter's hegemonic control caused other critiques to be subsumed under what appeared to be a universal experience of "the battered woman" (Dodson, 1982).

Although much of the analysis of the feminist movement regarding relations of dominance and subservience has been taken up by the battered women's movement, its two-decade history has nevertheless been marked by a reproduction of the race, class, and heterosexist oppression that dominates social relations in this country. White women, often from middle-class backgrounds, have held many of the structural leadership positions (e.g., coordinator, program director, fundraiser) and have written the majority of the literature. As Susanne Kappeler (1995) points out,

The issue no longer is white women's oppressive behavior, but Black women's absence from the movement - to which the quick response has been to issue an invitation addressed to Black women to 'join' the movement (ours), to participate in our conferences and to fill the ranks of our rallies so that these will no longer suffer from the stigma of exclusive whiteness. The enterprise remains in the interest of the entrepreneurs, but Black women are now in demand and needed to stave off any future critique that white women are excluding Black women. (p. 60)

Movement strategies, including legal reform strategies, were developed with women of color

\footnotetext{
8Immigrant women face the overlay of institutionalized sexism in their own cultures with the racism and xenophobia of the dominant culture in the U.S. (Dasgupta \& Warrier, 1996; Dasgupta \& DasGupta, 1996).
} 
often in reactive rather than proactive leadership roles. In these roles women of color have been far more cautious in mapping out strategies for reform that would involve an expanded role for police and the courts in women's lives. In some cities women of color have also placed greater emphasis on reforming the child protection cour processes than on reforming the criminal or civil court processes, because historically the role of state involvement in their lives has largely been organized around welfare and child welfare agencies (Abramovitz, 1988). A Minneapolis advocate explains,

It made sense for white women to look to the divorce process as the problem and in need of reform because that was the court that they had been using to try and get help. As Indian women, we have put a greater emphasis on the juvenile court because for us, turning to the courts for help to deal with being battered will very likely put us in a battle to keep our kids. (Interview, June 8, 1995)

Much of the early work of legal reform efforts was marked by a certain naivete on the part of the white middle-class leadership about the role of the legal system in maintaining existing relations of ruling.

I think white women talked more as if the courts belonged to us [all women] and therefore should work for us where we [women of color] always saw it as belonging to someone else and talked more about how to keep it from hurting us.-Legal advocate (interview, September 19, 1995)

While many of the key figures in the movement leadership were lesbians there was a defacto agreement that lesbians be closeted in their dealings with public agencies. In some shelters lesbians had to be closeted even to co-workers. There was no lesbian critique within the battered women's movement's discourse that paralleled that of Native American or African American activists. When lesbians in the movement did start speak from a lesbian position it was more on the rather narrow issue of lesbian battering than on an analysis of heterosexism and violence against women.

In every state, advocates formed coalitions of locally based programs to work for legislative changes as well as for changes in the state's regulation of local welfare, police, and funding agencies. The new legislation merely authorized change. Many of the laws and regulations 
passed were either ignored or cynically turned against battered women or against men in marginal positions in society. Thousands of women in the U.S. have been charged with assault when they have fought back against an abuser; many others have been arrested for failing to cooperate with the prosecutor's efforts to enforce criminal statutes against batterers. As a direct result of the reform efforts which envisioned a more active role for the courts in intervention, battered women have been charged with filing false police reports, failing to obey subpoenas, and neglecting their children (Pence \& Ritmeester, 1992).

We were told by police, "We can't arrest, we don't have the authority to arrest," so we spent an entire legislative session getting the law changed so that they could arrest and the next year a small number of men were arrested and a really high number of them were either Black or Indian men or else white guys who had given the cops a bad time. (Interview, June 8, 1995)

However, the grassroots nature of the battered women's movement created an infrastructure through which these practices could be challenged over a long period. Policy changes secured at the state or legislative levels would be taken up by advocates by means of local training programs for professional groups. Through constant pressure advocates kept raising issues about how particular cases were being mishandled by the system.

Few of the women who organized the battered women's movement were economically selfsufficient. Most were part of the working poor. Some were dependent on their husbands or dependent on the state, either as welfare recipients or as civil service workers. As women seeking refuge in the shelters turned to the state for financial resources or legal protection, the state's role in reproducing relations of dominance and subordination was repeatedly demonstrated. Lawmakers, police officers, judges, and social workers consistently failed to use their institutional powers to protect women from further abuse or to sanction men for their violence.

Even when the movement had secured legislation that expanded the institutional power to intervene, practitioners frequently refused to use their new powers. It was this reality that politicized movement workers. Feminist theory offered them an analysis of what they were 
experiencing each day they walked through the shelter door to begin a work shift or to escape a batterer. As women crowded into shelters, their stories revealed a disturbing pattern of specific actions on the part of legal and human service practitioners which seemed to collude with men's violence and intensify women's vulnerability to domination by violent men.

It got so I could finish a woman's story halfway through it. There was this absolutely eerie feeling that these guys were getting together and deciding what to say and do. The people in the system were saying a lot of the same things that the men were saying: "It's her fault, too. She has to take some responsibility for what's happening, it takes two to tango." Back then there were no arrests, no prosecution, no special visita tion orders. It's as if everyone just had blinders on to how violent some of these men were. Some women weren't shocked by this-they had been on welfare or in this system for a long time and had that jaded attitude toward the system. I was a novice, I was shocked at it. I remember thinking, "But the squad car says 'to protect and serve' on the door-how could the police just walk away?"- Shelter advocate (interview, June 15, 1995)

Each woman's story added to a picture of a legal system whose practices, procedures, and policies made it difficult for most women to use for protection from male violence and which remained virtually inaccessible to marginalized women.

I was trying to get away from him so I went to Legal Aid but I had to use our family income on the intake form. My income was nothing. His was about $\$ 25,000$, which meant I didn't qualify for an attorney. It wasn't like I could say, "By the way, Mike, can you leave a check on the table before you leave today? I'm off to see a divorce attorney.". . The same thing happened when I tried to apply for welfare and get an apartment. We were still living together, so I had to use the family income, which meant I couldn't get on welfare.-Former women's group member (interview, May 25, 1995)

Everyone kept telling me to call the police on her and have her arrested but I knew if Carla and I ended up in court together or if I tried to use a shelter, Jerry would find out and I'd be back in court all over again for custody. He could never quite prove to anybody that I was a lesbian. He just needed the proof to get the kids.-Former women's group member (interview, May 25, 1995)

Advocates began to understand that the failure of the courts and police to protect women was not simply a matter of an attitude on the part of individual practitioners. It was a lack of legal tools to intervene in a legal system that did not take into account the inequality of the possibilities of 
parties seeking court intervention in family matters or the complexities of women's experiences in a society in which citizens' access to resources and social privilege is determined by their sexuality, race, gender, and class position. These realizations led advocates to form legislative coalitions and criminal justice reform prnjects at the state level. Successful legal reform efforts in one state were quickly taken up by advocates in other states. ${ }^{9}$ Reform initiatives, such as laws that authorized civil courts to remove abusive parties from their homes, expanded police authority to make arrests, required jailers to notify victims when releasing offenders from custody, and allocated funds for shelters, would be passed in one state and within 3 to 5 years passed in over half of the country's state legislatures (National Council of Juvenile and Family Court Judges, 1996).

Activists also organized criminal justice reform efforts on the local level, either as separate projects within shelter programs or, in cases like the Domestic Abuse Intervention Project (DAIP) in Duluth, as independent sister organizations of the shelters. The first community-based legal reform projects focused on specific aspects of legal intervention. For example, Evergreen Legal Services in Seattle set up the first legal advocacy project for women who wanted to prosecute their abusers. The San Francisco Family Violence Prevention Project was the first major project to locate a feminist advocacy program within a prosecutor's office (Schechter, 1982).

When the Duluth project began in 1980, legal advocates in other cities had effected changes in every aspect of criminal court intervention, from dispatching to sentencing. DAIP gained national recognition as the first community-based reform project to successfully negotiate an agreement with the key intervening legal agencies to coordinate their interventions through a series of written policies and protocols that limited individual discretion on the handling of cases and subjected practitioners to minimum standards of response (Pence, 1983). These early reform projects placed victim advocates in a leadership role of bringing various actors in the system

\footnotetext{
'In Minnesota, for example, between 1977 and 1990, battered women's movement activists were able to successfully argue for the passage of 16 pieces of legislation. These included establishing shelters for battered women, expanding the ability of law enforcement officers to make arrests in domestic violence cases, requiring jailers to notify victims of the release of their abusers, and requiring judges to presume that joint custody is not in the best interest of the child if there has been domestic abuse.
} 
together to examine and change procedures across agency and department boundaries.

Within the battered women's movement there was little disagreement that it was the role of advocacy programs to challenge institutional practices that prevented women from getting the full protection of the legal system. There was, however, sharp disagreement over the extent to which battered women's activists could or should initiate reforms that would increase the presence of the police and courts in the lives of battered women. Activists debated efforts to require police to arrest batterers and to require prosecutors to pursue convictions as the multiple realities of women's lives came into sharp relief. Even when police uniformly apply their arrest powers to men of different or ethnic backgrounds, arrest does not mean the same thing to a Latin man and an Anglo man, to a poor man and a middle-class man, or to a gay man and a straight man; nor does it have the same impact on their partners. Movement activists were demanding the protection of women from an institution which has been instrumental in maintaining white patriarchal supremacy and suppressing resistance to the social order. The movement was caught in the tensions of responding to immediate needs of women and working toward long-term institutional change. Like tensions within all social movements, they took on complex meanings (Costain, 1982; hooks, 1984).

It was one of those you're-damned-if-you-do-and-you're-damned-if-you-don't things. When we started talking about arrest I knew it was going to be used against Black men for reasons other than hitting a Black woman. It was things like the Birmingham police arresting ten Black men to every white man that made me argue against it, but then I didn't want police walking away when a Black woman was beaten either. So in the end I supported a policy which meant in most cases the man would be arrested and Black women would be down there to get him out. That's the way it is.-Legal advocate (interview, June 23, 1995)

Politically, the battered women's movement has been oriented toward the very practical legal, financial, emotional, and medical needs of battered women. The sheer numbers of women coming into shelters necessitated a pragmatic approach (Costain, 1982). Women called the police when they were being beaten, they sought legal relief in divorce court, and they were dragged into juvenile court as allegedly bad mothers. The question of whether we should use the courts to protect women was in a sense rhetorical, as women were already inextricably hooked into the legal system. The more meaningful debate centered on strategy (Currie, 1990). 
I write this as if there is a common description or definition of a community-based advocacy program, but of course there is not. Some of these programs operate almost exclusively on volunteer labor while others have substantial budgets and staff. Some are operated by people with no previous political or organizational experience and others are staffed by people with academic degrees in human service administration. Despite the educational, class, and social differences that separate many of these programs, they are loosely connected. What has led them to enter into coalition with each other is the experience of working with women who face horrendous institutional obstacles in securing safety for themselves and for their children.

In the next chapter I will discuss the development of a legal advocacy approach which has become known as coordinated community response or domestic violence intervention projects. 


\section{CHAPTER THREE \\ INSTITUTIONAL ADVOCACY \& CRIMINAL JUSTICE REFORM EFFORTS}

As activists developed advocacy strategies at the state level, and community-based programs pushed for their implementation on the local level, two distinct forms of advocacy emerged: individual advocacy and institutional advocacy. Individual advocacy involves an advocate helping a woman consider her options and then pursue a course of action in the legal system. The advocate explains various court procedures and helps negotiate around obstacles. In short, it is the job of the advocate to help a woman achieve her personal goals in the legal system. The advocate may not agree with the choice the woman has made, but she is trained to support the woman's decision unless she cannot ethically do so (Davies, 1995).

For the battered women's movement, institutional advocacy is the sum total of those activities designed to change an institutional practice (i.e., policy, procedure, or protocol) which works against the interests and needs of battered women as a group. ${ }^{10} \mathrm{It}$ is rooted in individual advocacy in that institutional advocacy programs are informed by the everyday experiences of battered women as their cases are processed in the legal system. Institutional advocacy is committed to claiming the legal process for women who have very different goals in using the system than those in the system who process her case. Wittner's (in press) institutional study of women's agency in domestic violence court found battered women used the courts for many purposes; rarely was it to secure a conviction.

In these often invisible ways-broadcasting the news about court, discussing the problem of violence among friends and relatives, redefining the meaning and scope of unacceptable violence, rethinking their relationships with abusive men, reconceptualizing their rights and obligations, and reflecting on themselves-women made significant changes in their own lives, in their communities, and in the court. (Wittner, in press, p. 42)

In some cities legal advocacy projects have organized as independent organizations, while in others they are program components of shelters. In many cities, shelter or community-based advocacy program staff practice both forms of advocacy.

\footnotetext{
${ }^{10}$ Of course who defines these needs is a major issue.
} 
I always think of my role in doing individual advocacy as helping to clear a path for women who have chosen a course of action but are coming up against obstacles. My knowledge of the system and relationships with people in the system put me in a position to help overcome those obstacles. When I am doing institutional advocacy, I think of it more as clearing a new path. When an advocate finds herself coming up against the same problem over and over again with different women, it's clear something needs to permanently change.-Legal advocate (interview, June 15, 1995)

Institutional advocacy, however, also focuses on how the state should intervene with men who beat women, regardless of the desires of an individual woman who is the victim of an individual man. Thus the demands of the battered women's movement to criminalize violent men often conflict with the interests and desires of women who are living with those men (Edwards, 1989).

Women entering the first shelters came with a need for more than a temporary place to stay. Various kinds of discussion take place in shelters. None reveal more about women's lives, experiences, and needs than the conversations around the kitchen table late at night, when the children are all sleeping and the intense pitch of activity that marks each day has subsided. This is when women start to compare stories about police coming into their homes, phone calls from defense attorneys, subpoenas from prosecutors, and questions from child protection workers. This point of contact between the women's experience and the institution she encounters is the juncture where advocacy begins, the juncture at which an abused woman encounters the state as a "battered woman." It is the point of departure for individual and institutional advocacy:

I don't think anyone who hasn't been there can quite understand what it is like to have a huge fight with your husband, who decides to start punching home his points, then somehow you get to the phone without him cracking you over the head with it. It seems like it takes forever for the cops to get there. Every minute is like an hour. When you hear that knock on the door you have this feeling of panic-"My god, what have I done?" mixed with this feeling of relief-"My god, they're here!" So in walk two men. They look so calm, so powerful. Blood is dripping out of your nose, you feel like a train just ran over you, you look like shit, your house looks like shit, your whole fucking life and every mistake you've ever made is just hanging out in the air for these two men to see, and then it all starts: "Do you want to tell us what's going on?" Where do you begin? "I married an asshole, a drunk, a shit father, and I want him the fuck out of my life, but I need the bastard." Somehow I don't think that's what they're looking for but that is exactly what's going on.-Nancy, former shelter resident (interview, May 19, 1995) 
The police officer now represents both the state and, in a sense, the community. The advocate works with the individual woman to realize her goals. The institutional advocacy program works to define the role of the police officers, and of those practitioners who will take up the next stages of the case, as one of providing protection for this victim (and others) and deterring this offender (and others) from future violence.

The police officers, like the dispatcher, the prosecutor, the judge, and dozens of others, represent one part of the apparatus that defines, manages, and processes the experiences of battered women as "domestic assault cases" in a legal system designed to enforce social norms. Unlike other serious crimes, such as bank robbery, kidnapping, or drug dealing, "wife beating" is not yet considered an absolute breach of social norms.

I sat in the back of the courtroom that day and the probation officer told the judge that [my husband] was the hockey coach to my son's team and then he said that he had admitted to beating me up. So I guess because of that he was telling the judge that he didn't think my husband should go to jail. He told the judge that he should go back to the Domestic Abuse Intervention Project [men's rehabilitation group]. I thought, oh great, more misery, because he always found a way to make me pay for him having to go to those groups because of the protection order. It's like, why did I go get a protection order and then go through the arrest thing if the judge was just going to say, "Well, Mr. Hansen, let's give it one more go and see if you can get it right this time."-Former women's group member (interview, May 25. 1995)

D. E. Smith (1987) explores how everyday life in the modern state is administered through complex sets of "textually-mediated" processes. That is, people and their experiences are constantly processed through forms, files, memos, protocols, and records that turn an individual's experience into a "case." Lived experiences, such as a woman's experience of violence, is represented in and replaced by different organizational "texts" (forms, files, and so forth). The gap or disjuncture between the textually mediated administrative procedures and lived experience, between a woman's experience of violence and the way her experiences are inaccurately reproduced in texts and administered as a case, can be enormous. Nancy's story illustrates that from the first moment of intervention by the police, the case and her experience are in danger of becoming increasingly unrelated: "Somehow I don't think that's what they're 
looking for," observes Nancy, but she knows that what they're looking for is not "what's going on."

When we think about the state and power, we often think about repression or the use of armies and police forces and knocks on the door at night. ${ }^{11}$ But it is important that legal advocates think carefully about the other ways in which power is practiced by the modern state. The gap between a woman's experience of violence and the way the various agents of the state treat it as a case is neither benign nor politically neutral. It is a gap that carries the imprints of the practice of power that produce it. Thus in U.S. society, the disjuncture between lived experience and the way this experience is administered is a profoundly gendered, ${ }^{12}$ raced, and classed one.

Power in modern societies operates more pervasively through knowledge and social technologies such as professions and disciplines than through repression and coercion. Fraser (1989) draws on Michel Foucault (1979), who likens the practice of power in the modern state to a capillary, whereby power is widely dispersed and disseminated through multiple discourses and technical or professional processes, such as those of law, psychiatry, or social work. These discourses, she explains, work by defining the proper or normal conduct of everyday behaviour so that "power touches people's lives more fundamentally through their social practices than through their beliefs" (p. 18). That is, hegemony works through the disciplinary practices of the professions or other occupational groups and through the day-to-day operations of institutions. Education programs to change the attitudes of police officers or judges therefore simply won't work by themselves. Battered women's advocates must challenge the way power works through dominant knowledge practices. Joan Scott (1988) defines knowledge broadly:

Knowledge refers not only to ideas but to institutions and structures, everyday practices as well as specialized rituals all of which constitute social relationships. Knowledge is a way of ordering the world. . . it is inseparable from social organization. (p. 2)

Thus not only is knowledge deeply implicated in power relations, but power relations are

\footnotetext{
"Repression is reserved for the politically poweriess and socially vulnerable.

12 By gendered, I mean to include attention to sexuality.
} 
embedded in the kind of knowledge that is institutionally produced about a woman's experience of violence. For D. E. Smith (1990a), knowledge created in this way carries in it (and is part of) the social relations of ruling. She shows how such knowledge is an ideological practice "that subdues the lived actualities of people's experience to the discourses of ruling" (p. 4).

Thus, for example, as a woman's call for help is recorded by the 911 operators, the technology of the system sets into motion a methodical and consistent administrative process of structuring, analyzing, and ordering her experience so that it is reduced to a form through which those practitioners who operate the court systems eventually can know and resolve the case ideologically: that is, as the object of court and legal practices rather than as the subject of lived experience.

Legal documentary practices produce accounts of violence against women as a series of criminal incidents rather than as a sustained, pervasive pattern of coercion and intimidation. As such, each incident is treated as the crime to be processed. This conceptual practice is reinforced by similar practices in the social sciences, which produce understandings of violence quite unrelatea to the way women experience it.

\section{Conceptual Problems in an Incident-Focused System}

The criminal court process is incident focused. The goal is not to determine if a defendant is battering his partner, it is to determine if he assaulted her on a particular day. Let us begin this discussion by starting in what $\mathrm{D}$. E. Smith refers to as the pre-categorical place of the everyday lived experience. Marilu has not yet been pulled into this institutional maze. One Tuesday night she is punched in the face by her husband during an argument over who is going to use the car. Their youngest child hears the argument and her mother's scream. She runs down the stairs and sees her mother bleeding, holding her nose, and yelling at her father. She is afraid and calls 911 , which she knows as the police number. It is early evening. Marilu has to be at work the next morning, as does her husband, Jerry. Dinner is just about ready. Two of the children are leaving for camp at the end of the week. The third child has been sick all summer with a viral infection. This is not the first time Jerry has hit Marilu, although it has been over 2 years since the last physical abuse occurred. In the past year he has thrown things, screamed in her face, punched 
walls, and taken her car keys. She's done some of the same, called him names, kicked him in the shins, thrown his favorite shirt in the garbage. There are literally dozens of details about this woman's life that are important to her. In a few moments when the police arrive and ask, "What"s going on?" everyone will know they don't mean, "Tell me everything that's going on." They want to know about this fight and this blow to the face. And so from the first point of contact, the everyday lived experience is being "worked up" for institutional action.

There is Marilu's life and its particulars, and now there will be another reality into which her reality will be drawn and reshaped. A woman told me once, "Calling the police on your husband is what it must be like to get beamed up to the Enterprise." For her, calling the police had meant she'd entered another world with words she understood but sentences that made no sense. Everyone asked her questions, but no one sat down with her to figure out what to do. She knew she was the object of everyone's gaze but not a part of the discussion about what to do with her.

The criminal court system is designed to determine if an incident that occurred in a community was a criminal offense. If so, who was the offender? If the offender is identified, can it be shown beyond a reasonable doubt that this person committed this crime? If so, what should the state do to deter this offender from committing similar acts in the future, and what can be done to deter others from committing similar crimes? Typically, the goal of the woman is to stop the violence, not to secure a conviction (Ford, 1983).

An incident-focused system does not routinize a method for practitioners to account for contextualizing the events surrounding an assault. It does not require the observer to account for the power relations, the history or pattern of violence that surrounds an event, or the way that violence arises in a relationship.

Advocates are not the only ones who find working within an incident-focused system problematic. In my discussions with prosecutors, probation officers, and judges the issue was repeatedly raised. One prosecutor discusses a case in which she tried to stretch the confines of the incident-driven system. The case involved a man with a long history of psychological, verbal, and minor physical abuse of his wife. But his obsession with her as she tried to leave the 
relationship made advocates bring this case to the attention of the prosecutor as potentially quite explosive. He had been arrested for an incident in which the physical contact was minimal. The hearing shows the limitations of an incident-focused system. The prosecutor's observations when I interviewed her serve as a good introduction to the court transcript, found in its entirety in Appendix A:

I just wanted to get some controls on him [the abuser]. He was dangerous, and of course you can see from the transcript I failed, but later the police arrested him with a gun and a suicide note. Eventually he got put away, but he could easily have killed her and we would have once again failed because we aren't able to look at the whole picture of what's going on. In this case the judge fought me the whole way. He was mad that I was insisting on bringing this to trial. He wanted it dismissed at the pretrial for lack of probable cause but I asked for a Rasmusson hearing. ${ }^{13}$ I think the judge thought I was being just stubborn by not just dropping it. And I was, but I really had a feeling that this guy was going to do something. This transcript will show you that I made a mistake by focusing on if she was in fear and not focusing on his intent but still it's a good example of trying to get the incident in perspective. (Interview, September 15, 1995)

(Excerpts from Appendix A)

[Prosecutor]: Thank you. Our first witress would be cindy Indrews. The Court: Go ahead.

TESTIMONY OF CINDY ANDRENS,

2 What I would like to do is go into that a little bit with you. ‥ the time of this incident on January lst, did you have an orde= for protection in place?

A No, I did not.

$Q$ You've subsequently obtained one, is that zight?

A Yes.

Q Had you had any order for protection in place throughou the naneyear relationship, of at any time?

[Defense Attorney]: Judge, I'm going to object to this line of

questioning. It's irrelevant to this. The issue at hand is whether there's probabie cause for the assault charge which occurred on January Ist.

[Prosecutor]: Your Honor, I expected that objection and the State's reasoning here is that the type of assault that we' re talking about, as the court will hear in the next few minutes, does not involve actual harm being inflicted. It involves physical confrontation but without actual harm. And the theory-the section of the statute the state is proceeding under is section. 609.224, subdivision 1, parenthesis (1), as well as (2), which indicates that it is a miscemeanor to commit an act with intent to cause fear in another of immediate bodily harm or death. The state's theory here is that Ms. Andrews was made to be afraid and her fear is based on the whole history of this relationship. That the history of the relationship is relevant to the determination of whether she was afraid on January ist of 1995.

The court: I'll let it go for a while. You don't have to go on forever

\footnotetext{
${ }^{13}$ A Rasmusson hearing is held if it is questionable that there is enough evidence to proceed with a trial but the prosecutor wants to do so.
} 
in detail with regard to prior orders and the like.

[Prosecutor]: okay.

$Q$ (Ms. Hewler, continuing) Briefly, Ms. Andrews, can you tell lis if you've had two prior orders for Protection?

A. Yes, I have.

$Q$ When did you obtain the first order?

A The first order was July of' 89 , and second order was che summe= of ' 93 .

$Q$ Has there been a history of physical violence in your relationsize with Mr. Andrews?

A Yes, there has.

$Q$ And can you describe briefly for the court the time period under which that has happened?

[Defense Attorney]: First of all, she tried to block him down in the basement from taking property, and then he in turn goes up and calls 911. follows him back up and then she disconnects the phone. While at one time she is saying she's afraid of him and being afraid of being assaulted by him, siee interferes with calling the law. People want law-enforcement to come if the: were really afraid. . .

[Prosecutor]: Your Honor, I would argue there is probable cause. Tine state clearly indicated that it is an assault to place someone in fear of immediate bodily harm. That's how we' re proceeding here. Yes, there were no threats. Yes, there would be no injuries. . Sut there was definitely an assault. . . Officer Bronte described her as being upset and in

tears. - . It was suggested that a normal person wouldn't unplug the phose, but this isn't a nomal situation. That's the whole point cf this pazticilaz case. . . This is a situation where there has been an extended histcry of violence. . . I believe she testified to that very clearly when she said she knew what his patterns were, what his habits were, and 1 t he was argry that he wouldn't leave the home. That she sensed somethirg worse was goirg :a happen.

The prosecutor here has worked to have testimony entered into the record that puts the relatively minor incident into the context of a relationship in which there is an extended history of violence. By doing this the prosecutor is arguing that one cannot look solely at the behavior of the defendant that evening; the way his past use of violence impacts every exchange he has with the woman he has beaten must also be considered. Ultimately the prosecutor is unsuccessful in proceeding with this case because she is unable to convince the court that the fear that the victim felt was intentionally inflicted by the defendant.

\section{(Excerpts from Appendix A)}

The court: Wait a minute. We have to deal with it now or deai with it later. The state does not say it's against the law to place one in fear of bodily harm-I don't have any qualms about the fact she was in fear of bodily harm. The statute you're talking about is an act done with intent to cause fear of bodily harm. So-

[Prosecutor]: That's right.

The court: So your argument should not be related to her state of fear, which I don't question with the history, etcetera, but his intent with what he was coing. That's where the problem is.

[Prosecutor]: This is a man who has an underlying history of belng violent in his relationship. A push from him would mean something fas cifferent to his wife and [he] knew that. He knew that. He knew that he 
could make her afraid by pushing her. He knew that his voice-ali of his actions because of what she has come to court to say-she knew how to read his signals. . . .

[Defense Attorney]: Judge, it just isn't there. There isn't any evidence showing that his intent was to ham her or even calse her to be afraid. . .

The court: - . Now, I think the police did what they had to do unde: the circumstances. They were called to potential problems. But you' re talking about taking into consideration all the circumstances when you determine intent, and I think you also have to take into consideration that she was blocking his path. I don't think that there is-you know, we' re going to have to do this now or do it again. I don't think you'll be able to get it to a jury, to be frank, Ms. Hewler. I don't think there is enough to get $2 t$ to a jury. . . I don't like it, but I'm going to have to dismiss it Eo= lack of probable cause. That is all.

Here both a prosecutor and police officer attempt to step back, look at the whole picture of what is happening in this relationship, and make the criminal law act in ways that protect the victim. Both are prevented from doing so, not because they don't have the personal consciousness to see that this is a pattern of abuse, but because of both the specialization of the court system and the way the law produces an account of violence that conceptualizes it as a series of incidents rather than as a sustained pattern of abusive, controlling, and intimidating tactics used by batterers to establish authority and power over victims.

In this case police officers arrested because they knew the history of this abuser and wanted to try to get the case into the system. The prosecutor here is trying to make an incident-focused system account for a pattern of abusive behaviors. Even though the judge says he's familiar with the whole case and refers to it as a "chaotic situation," he rules to dismiss because the prosecution has not adequately shown that Mr. Andrews' actions that evening were specifically intended to cause Ms. Andrews fear. The prosecutor tries to argue that the whole relationship is based on his knowing how to place her in fear, but in this instance the argument fails. The prosecutor has a weak case because the incident must stand alone in a criminal proceeding. The prosecutor's efforts to use this arrest as a way of gaining some leverage for state intervention and protection is thwarted in an incident-focused system.

Social Science's Reinforcement of Counting Incidents

I want to briefly discuss how the work of sociologists can link into the law's focus on the incident, decontextualizing the violence women experience and masking the danger many 
women face. Murray Straus, Richard Gelles, and later, Susan Steinmetz were among the first U.S. sociologists to take up the task of scientifically defining and describing woman abuse as a problem. They have since become the foremost U.S. academic authorities on the subject of family violence. In 1975, Straus released the findings of their National Family Violence Survey, which he had conducted with Gelles. It confirmed what shelter advocates had been saying: lots of women were getting hit, many quite severely (Straus, Gelles, \& Steinmetz, 1980). The survey involved 2,143 members of "intact couples" in order to document the number of people who physically abuse their partners. The study also measured the frequency with which these acts of violence were committed. The researchers designed the "Conflict Tactics Scale" (CTS) to measure objectively what they called "conflict tactics." The survey identified the number of times in a year that 1,179 women and 964 men had engaged in the use of violence against their partners. Each survey respondent was asked to choose from a list of 18 possible conflict tactics, about half of which are "assaultive" (Straus, 1979). The list includes items such as "threw something," "pushed," "grabbed," "slapped," "used a knife or a gun." The scale does not measure injury; instead, it divides assaultive tactics into two categories, "minor" and "severe," paralleling the legal distinction between simple and aggravated assaults. The perspective of the victim did not figure in the measurement of "minor" or "severe": The so-called hard data were detached from the actual experience. Thus, on the CTS, a woman who kicks her husband while he is choking her will be scored as having used a severe tactic of violence (Okum, 1986).

This measuring instrument obscures everything that needs explaining. Let us take the fictitious case of a mother with three children. Her husband works for an accounting firm and she is a homemaker. She has twice been hospitalized as the result of his abuse. One night he comes home several hours late, appearing to be drunk. She yells at him and calls him names. He starts to walk toward her and she tells him not to touch her. He smiles and continues toward her; she throws a vase at him and it hits him in the arm. He grabs her by the hair and tells her that if she doesn't shut up he will smash her face. So far it's 1:2 on the CTS. She then kicks him hard in the shins. It's now 2:2. He pounds her head into the wall several times and she reaches out and scratches his face. He lets go and she runs out of the house and goes to her sister's for the next three days. It's $3: 3$ on the CTS. 
The study by Straus and Gelles confirmed that battering relationships constitute a social problem of enormous magnitude. It also claimed, however, that equal numbers of men and women are victims of domestic violence. In their initial reports the mutuality was downplayed as not as dangerous to the men, but by 1977 , Straus, in collaboration with Susan Steinmetz, began making claims that husband abuse was a large and ignored social problem (Steinmetz \& Straus, 1977; Straus, 1989). The claim got good press play and gave currency to the argument that battering is not so much a gender problem as it is a problem of intrafamily violence. Once again the particulars of women's experience are lost as scientific screening devices are institutionalized, allowing scientists to manufacture data which are taken up as fact by practitioners in institutions of social control (Yllö \& Bograd, 1988). The origins of their making disappear.

For a battered woman violence is part of her relationship with her partner. She does not experience or reflect on the violence as a series of incidents, yet this is how it is taken up by the legal system and analyzed by social scientists. The notion of counting blows and documenting specific incidents of violence becomes a conceptual practice. It prevents interveners from seeing how dangerous many abusers are to the women they assault. However, as the case of Cindy Andrews demonstrates, both advocates and practitioners alike are cognizant of the legal system's inherent limitations in protecting women who are abused. The practitioners who attempt to push the boundaries defined by legal processes tend to be the ones who form alliances with community-based advocates in the effort to transform the system.

\section{Issues of Leadership in Reform Efforts}

Community-based advocacy projects brought women without law degrees or any official legal standing in a case into the courtroom to advocate for individual women. Institutional advocacy programs extended their presence into the administrative workings of the system, inserting advocates into discussions on the managerial practices of the court system and demanding a voice on behalf of women as a class. Their presence was met generally with resistance and occasionally with cooperation. In some cities, they were charged with practicing law without a license or accused of "man hating," gender bias, and obstructing justice (Davies, 1995).

While many advocacy groups and shelters have had tense relationships with police departments 
and the courts, there was often a recognition that a cooperative relationship would be in the interest of both groups. Shelters gave police as well as the courts much-needed resources to deal with a crime they had previously been ill equipped to handle. Besides offering emergency housing for women, shelter programs coordinated the legislative initiatives to expand police arrest powers, judicial authority to quickly remove violent offenders from the home and to hold them following arrest, and prosecutorial ability to bring certain evidence into the courtroom. With these expanded powers came rising expectations that the court act to protect women and children in far-reaching ways.

The judicial system in any community is a collection of agencies with ties to different levels of government. Decision-making power is not centralized in any one agency or person. Some practitioners work for the state (judges), some work for the county (jailers, dispatchers, probation officers, and county prosecutors), some work for the city (police officers and city prosecutors), and some work for the federal government (appellate court judges). In Minnesota, each judicial district has a court administrator who works essentially under the direction of the judges of that district. The administrator supervises the courthouse staff, clerks, and bailiffs and the administrative processes they all perform, such as creating court calendars, dealing with the flow of paperwork, developing forms, maintaining filing systems, and operating computer systems. Judges hold bi-annual elections to choose a chief judge to coordinate their administrative processes.

Making changes in procedures or policies in this network is complicated by the multiple sites of decision making. There is of course the formal, recognized division of tasks and power as well as the informal and often more contested terrain of policy making. Systems advocacy requires advocates to promote changes that take into account the multiple agendas of intervening agencies while maintaining their own priority of victim safety. There is no single person in the legal system whom advocates can approach to revamp the court's response to these cases. Each agency has to be brought into the process of change and each change in an individual agency has to be coordinated with the other agencies either affected by the change or necessary to make the change take place. 
Advocacy programs attempt to achieve changes both at the macro level (e.g., passage of new laws or adoption of new prosecution, probation, or police policies) and at the micro level (e.g., making changes in procedures and in daily court and police practices such as setting court calendars, arranging a safe waiting space for women and advocates, determining what information belongs in a police report, and presenting sentencing recommendations to the judge). Both levels of advocacy require careful attention to the way one change will impact another par of the case processing. Legal advocates generally consider any change they or others propose from the standpoint of how it will impact battered women, both as a class and as individuals.

Legal advocacy projects which have made a commitment to avoid the stereotypical assumptions about the "universal" battered woman also analyze proposed changes from the point of view of women occupying different social positions in the community (Weisberg, 1993; McAllister, 1982). In our society, women's experiences with multiple forces of oppression-as African American, Latina, Native American, poor, illiterate, lesbian and immigrant women-means that although there is a common ground that women share as battered women, there is no universal experience of being battered. These socially different subjective positions of women do not mean that a woman is first battered as a woman, then as a poor woman, then as a South Asian poor woman. Being a woman and South Asian and poor are simultaneous experiences that compound and mediate each exchange as she negotiates her way through the legal bureaucracy.

When an institutional legal advocacy project first organizes in a community, it typically has an ambitious agenda for major policy changes in several agencies. Often the goal is to ask key agencies to simultaneously adopt new written policies. Negotiations for this kind of coordinated change take months and even years to complete. The absence of a central administrative body or person in the court system requires that change which impacts several parts of the system be negotiated with several key policy makers. Local politics as well as the adversarial nature of the legal system affect the negotiations. Frequently the tensions are such that practitioners become openly hostile to each other. In some cities, particularly those at the forefront of community intervention, legal advocacy projects have played a key role in drafting, negotiating, and strategizing for the implementation of changes. In other cities, advocates have worked closely 
with one or two administrators within the system who assume the main leadership roles but closely ally themselves with the advocacy program (for example, San Diego). Elsewhere the advocate's role in influencing reform efforts is severely curtailed and marginalized by practitioners who have no commitment to a victim-referenced reform effort.

In the past 5 to 8 years a growing number of policy makers inside the legal system have taken up the banner of reform. Advocates in the battered women's movement do not claim a monopoly on the right to speak about domestic violence, but as Gillian Walker (1990) argues, we do insist that the standpoint of battered women become the prerequisite grounds from which to be truly selfand institutionally reflective about proposed reform of the court system.

The battered women's movement's legal agenda is one of reform. It does not actively pursue a fundamental restructuring of the law or the law's role in sustaining race, gender, and class oppression. It does not challenge the underlying assumptions of heterosexist concepts of family or friendships or intimacy (Rich, 1980). Indeed, this reality has led to a critique of legal reform efforts by a number of feminist theorists (Brown, 1992; Currie, 1990; Pateman, 1987; Smart, 1989). They find the legal system to be so hopelessly masculinist that there is no possibility for producing meaningful change for women. Wendy Brown argues,

If . . . state powers are no more gender-neutral than they are neutral with regard to class and race, such an appeal involves seeking protection against men from masculinist institutions, a move more in keeping with the politics of feudalism than freedom. Indeed, to be "protected" by the very power whose violation one fears perpetuates the specific modality of dependence and powerlessness marking much of women's experience across widely diverse cultures and epochs. (p. 9)

Through its legal reform efforts the battered women's movement calls into question the way the law sustains one practice of male dominance: the physical chastisement and control of women in their intimate relations with men. The legal advocacy work within the battered women's movement works within an institutionally acceptable framework of community activism to influence the way the law is practiced. Many of the demands of the battered women's movement are achievable precisely because they do not require a basic restructuring of the legal system. 
During my conversations with battered women's activists in Minnesota about their work, many expressed awareness of a boundary around legal reform efforts that left the basic organization of the legal apparatus intact as they focused on how people within that given framework go about their work.

I'd like to think of myself as doing something really big, even historically significant, and in a way this is, but it's also a lot of tweaking. Making the law be better, given what it is. We don't ask some of the really big questions, like why don't we do away with this whole idea of an adversarial system producing truth or justice. (Interview, May 26, 1995)

Well, where do you start? I know we can change a law. I know we can change lots of outdated practices. I wouldn't have any idea how to restructure the thing--besides, I can't think of who would fund a proposal to reorganize the entire legal system. (Interview, May 26, 1995)

Lots of little things don't make sense to me-like the way they do arraignments, so much time is wasted-but also big things don't make sense, like why isn't the battered woman the client to the probation officer, why is the batterer? They spend all this time asking him things he'll never tell the truth about and then they make a reasonable, or good faith, or something like that, effort to talk to the victim. Why not spend time trying to find out what happened and talk to the woman and people they both know? But we never really discuss changing people's jobs totally, we mostly just look at how people are doing jobs that are already agreed should happen. (Interview, May 31 , 1995)

The Key Activities of Institutional Advocacy Projects

As they work toward court reform, community-based advocacy projects engage in a fairly complex set of activities that occur simultaneously. I'd like to provide here a general description of the kind of activities that constitute an advocacy project in order to later demonstrate how a community audit on centralizing victim safety in the management of domestic violence cases can have crucial implications for a reform strategy. Most reform work falls into one or more of eight general program categories: ${ }^{14}$

\footnotetext{
"These objectives were prepared by the staff of the Duluth Domestic Abuse Intervention Project in 1994.
} 
(1) Creating a coherent philosophical approach centralizing victim safety

(2) Developing "best practice" policies and protocols for intervention agencies which are part of an integrated response

(3) Reducing fragmentation in the system's response

(4) Building monitoring and tracking into the system

(5) Ensuring supportive community infrastructure of support

(6) Intervening directly with abusers to deter violence

(7) Undoing the harm violence to women does to children

(8) Evaluating the system's response from the standpoint of the victim

(1) Creating a Coherent Philosophical Approach Centralizing Victim Safety Successful intervention projects require the negotiation of a philosophical framework that will provide a network of interveners a basis around which it can organize and through which the negative impact on victims of contradictory philosophies, different perspectives, and fragmented response systems will be lessened. The practice of referring all actions back to the priorities of victim protection, accountability, and deterrence offers such a core organizing framework.

A central goal of institutional advocacy projects has been to eliminate the pervasive victimblaming practices of the current system and to shift the onus of holding offenders accountable from the victim back to community institutions. In practice, this means changing the way practitioners think about the cases before them. It means changing how they understand domestic violence, how they understand the relationship of the offender to the victim, and how they understand the potential for further violence. It also means changing who they see as responsible for undoing the harm caused by the violence and what they understand to be the respective roles of the offender, the victim, and the community in ending the violence. A legal advocate describes what it is like to do this kind of work: 
I think we spend a great deal of our time fighting against the notion that these assaults are logical extensions of relationship problems or dysfunctions. We have picked up some allies in the mental health profession, but the mainstream is still a powerful force in the legal system and their way of seeing violence as an individual pathology has been hard to overcome. We also battle endlessly against the blatant and subtle ways that people in the system blame women for getting battered. But our biggest effort still comes down to getting systems people to develop a sense of urgency in these cases. In towns like ours, 80 to 90 percent of homicides are domestics, but the sheer volume of these cases lulls people into a passive intervention role. (Interview, May 26, 1995)

Advocates have used safety as an organizing framework for a legal reform agenda, which in practice has meant that the violence cannot be decontextualized. But there are many ways to put violence into context. Mahoney (1991) suggests that contextualizing power means that we must understand what its use accomplishes for men.

Violence is a way of "doing power" in a relationship ... The stereotypical image of a battered woman - dysfunctional, helpless, dependent-is alien to the self-image and selfknowledge of most women who encounter violence from our partners ... These reciprocal, mutually reinforcing forces of popular perception, law, and litigation have made it difficult for women to identify ourselves and our experience as part of a continuum of power and domination affecting most women's lives. The challenge is to identify legal and social strategies that allow us to change law and culture simultaneously, by illuminating the context of power and control within which a woman lives and acts. ( $p$. $82)^{15}$

The battered women's movement has generally maintained that men batter women as a way of establishing control. This analysis is feminist in that it makes visible the power relations present in abusive relationships. However, centralizing safety as a goal and power dynamics as an indicator of safety still marginalizes much of what needs to be explicated to fully understand this violence. Obviously there is a link between battering and what Rich (1980) calls "compulsory heterosexuality." Men's violence may not be so much a need or desire for power as it is a logical extension of their place in the economic and socially organized relations of ruling in society.

\footnotetext{
${ }^{15}$ Mahoney provides an excellent discussion on the need for advocates for battered women to stop participating in the process of mal-defining battered women and to start understanding violence as men's way of doing power to keep women from autonomous action. She argues on behalf of a theory that defines men's use of separation violence.
} 


\section{(2) Developing "Best Practice" Policies and Protocols}

\section{for Intervention Agencies Which Are Part of an Integrated Response}

Training wasn't going to do it. We've had to push for written policies and protocols that provide some kind of standard of response. She calls 911 and from then till she's done with the whole mess there could easily be thirty or forty people who have something to do with her case. In a city like ours several hundred different people get involved in some part of the case. Without some fairly clear guidelines as to what are acceptable responses and what are not, we are going to be all over the map in what we do as a community. - Legal advocate, interview, June 15, 1995)

Victim protection will not be achieved simply by having actors in a coordinated response system think differently. They must act differently. The actions of those located in different parts of a coordinated system need to be both oriented towards victim safety and organized in ways that complement rather than undermine or subvert each other. With this goal in mind, practitioners' decisions and actions need to be guided by sets of protocol standards and, in some cases, direct policies. These are sometimes referred to as "best practice" standards, policies, or protocols.

But questions arise. When should the discretion of the individual practitioners be restricted by such protocols? Under what conditions should police officers be required to arrest? Should prosecutors pursue convictions when victims have asked to have cases dismissed? These sorts of questions, however, cannot be easily addressed from one site. Change needs to occur at numerous places within the system.

Protocols generally govern three things. First, they govern individual practitioners responses to specific cases. For example, they specify under which conditions police will arrest, probation officers will recommend jail time, or jailers will release suspects. Second, protocols govern practitioner's interactions with other practitioners in the system, with victim advocates, and with other community-based agencies. Protocols reduce system fragmentation. They help coordinate the often widely scattered parts of a coordinated response. Third, protocols address the issue of accountability by linking the agency with a monitoring system and a mechanism through which practitioners' actions can be questioned. 
To make protocols victim referenced, therefore, one needs to ask the following questions: Does this protocol enhance the victim's safety? Do case management considerations supersede victim safety? How do this policy and procedure impact victims' self-determination and autonomy? And how does this policy account for the power differential caused both by the violence and the differing social positions of the victim and offender?

\section{(3) Reducing Fragmentation in the System's Response}

I can't tell you how many times I've seen a total breakdown in communication cause a case to be lost or dismissed. Every time somebody gets seriously hurt or killed, everybody scrambles to the files to make sure they didn't mess up. If they didn't there's a big sigh of relief, but there's always this awareness that on so many cases there's a screw-up.

-Court clerk (interview, January 15, 1996)

Typically, the work of legal practitioners is bureaucratically organized. In occupationally specific ways, each has been trained in a method of subsuming the specifics of individual cases so that they fit the available repertoire of problems or issues with which that practitioner works. Practitioners fit the experience of the real world into the terms, categories, modes of organizing, accounting, and evaluating provided by their work and its location in the relationships of ruling in society. Individual women's experiences of violence become absorbed into bureaucratically sanctioned, objectifying accounts, designed for "case management" and the control of people who are part of "the case." Officially sanctioned "knowledge" is expressed in terms of management-relevant categories and becomes part of the way power works in the reproduction of gender inequality.

This fragmentation creates troubling contradictions for the work of legal advocates in the battered women's movement. As I will show, the terms of their activism are shaped by the practices of fragmentation and specialization in the system they are trying to change.

Legal advocacy can reduce the consequences of a fragmenting bureaucratic process by promoting procedures which orient all of those processes to victim safety. The procedures include documenting the history of abuse, promoting interagency consultations on cases, and helping 
change job descriptions-for example, questioning why a probation officer's primary client in a domestic assault case is the offender rather than the victim. Advocates constantly focus on the issue of justice by linking each step in the legal process to the experience of the woman who has been beaten, asking, "Does this community response protect women?"

(4) Building Monitoring and Tracking into the System

We needed to keep pushing for accountability. We wanted the court to see itself as accountable to a community, to women who were being beaten, and to in turn hold the abuser to some standard of accountability.-Legal advocate (interview, June 22, 1995)

One of the most crucial aspects of a community intervention program is accountability. Practitioners need to be held accountable to each other and, ultimately, to the priorities of victim safety, deterring individual batterers from further use of violence and creating a general deterrence to the use of violence within intimate relationships.

The Duluth DAIP has negotiated an interagency tracking system to provide its participating agencies with information. The tracking system allows information to be shared, allows cases to be followed from inception to closure, and reveals trends in the way cases are handled. Figures 1 and 2 illustrate the collection and distribution of information within this system. A DAIP staff member collects this information and disseminates it on a predetermined "need-to-know" basis. 


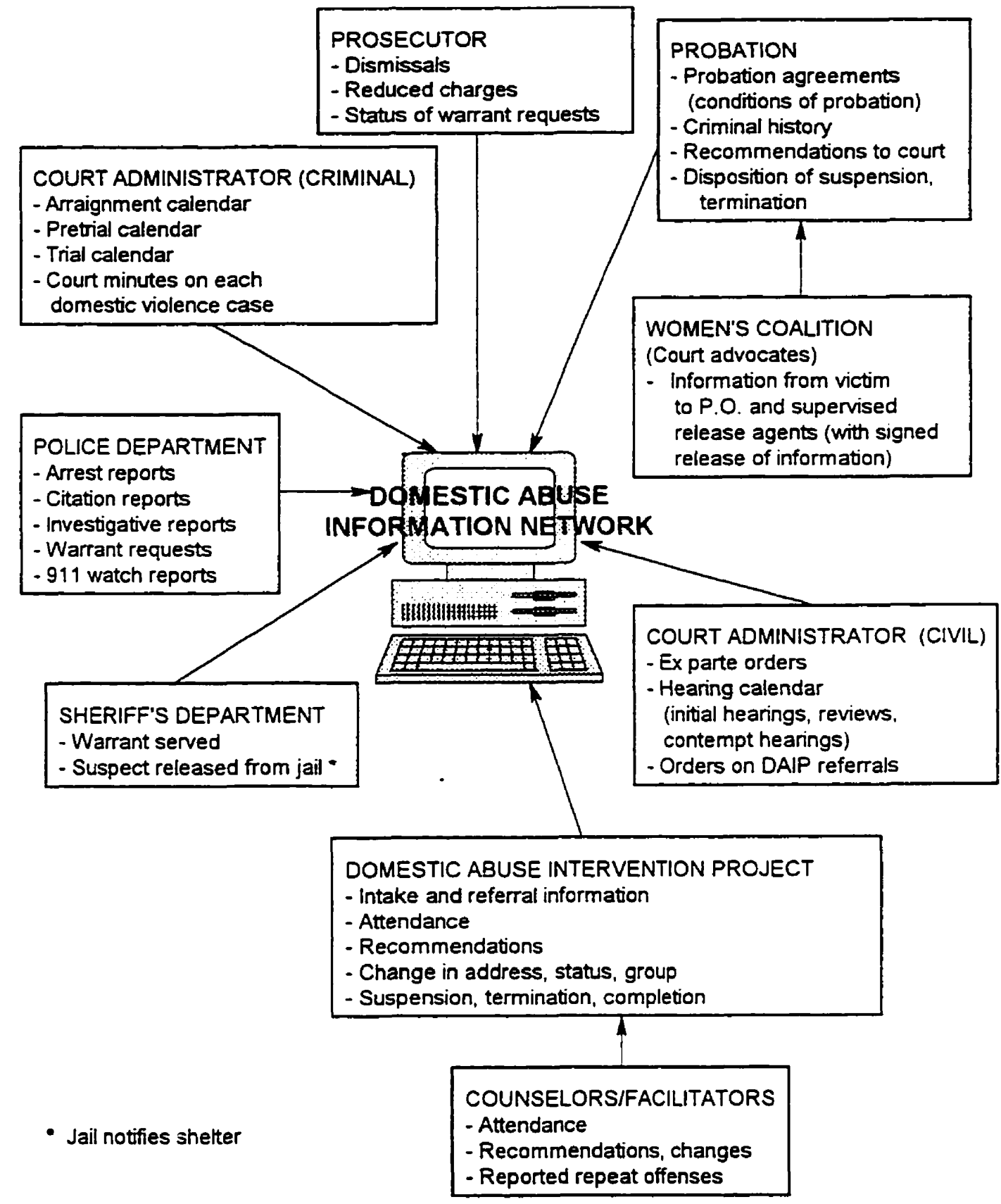




\section{FIGURE 2: DISTRIBUTING INFORMATION AND REPORTS}

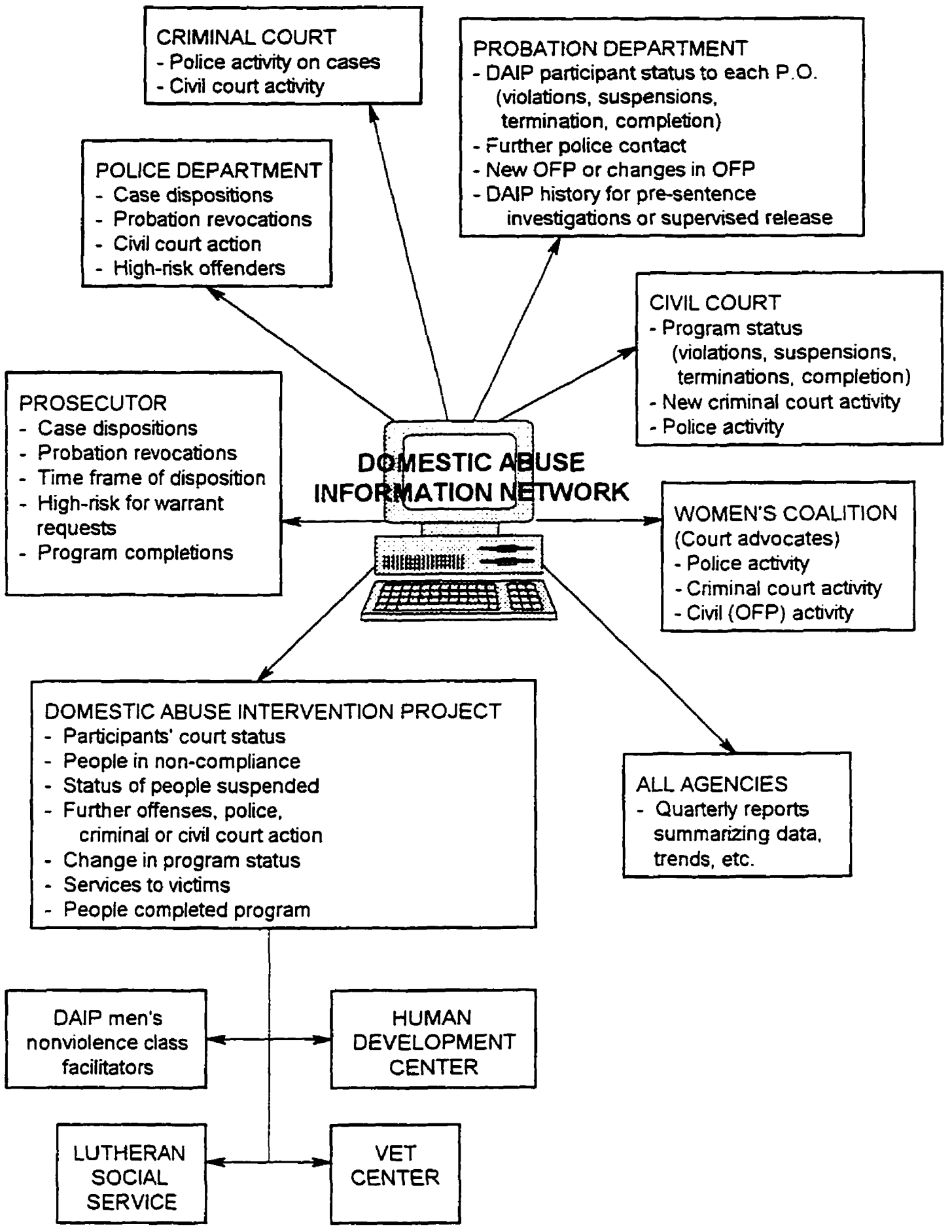


A tracking system allows a review of large numbers of cases in short periods of time. The DAIP issues a monthly report that alerts readers to patterns and problems not visible when cases are responded to individually. For example, a recent probation report from one Minnesota community revealed that there were 37 men on probation who had been reported by their rehabilitation program for failure to complete the program. All 37 of these defendants were thus in violation of the conditions of their probation. In 11 of these cases the probation officers had known about the violation for more than 14 days but had not issued a warrant or contacted the defendant; 9 of the cases belonged to the same probation officer.

Individuals reading this monthly report attach to it different meanings according to their location in the system. It alerts the sheiter advocate, working outside the system, to contact individual women who may be at increased risk of harm: most men who reoffend in the Duluth project drop out of their groups just prior to using violence or shortly thereafter. It points out a potential personnel problem to the supervisor of the probation department. It warns the probation officer whose name appears on the list nine times to take action. It gives the legal advocacy project in the community a reason to meet with the probation supervisor.

A tracking system might also, for example, tell the reader that there are 60 outstanding warrants for batterers and that 35 of them are over 60 days old. Such a report can stimulate efforts to unclog the system. Perhaps the data shows that 90 percent of all those cases in which a charge of assault was reduced to a disorderly conduct were handled by the same prosecutor. Perhaps it shows that one judge consistently denies petitions for protection orders, or that 20 men who have been assigned to batterers' groups have not yet made contact with the program. A tracking system allows a community to hold itself accountable to the policies and procedures it has adopted to protect victims.

(5) Ensuring a Supportive Community Infrastructure of Support

Legal remedies are not enough. A community needs to provide some basic resources for women, like shelter, long-term housing, a decent income, and a place to talk with other women in the same situation.-Shelter advocate (interview, September 11, 1995)

In the U.S. the most effective legal reform programs tend to be located in communities with 
strong infrastructures of services for battered women. Coordinated community responses need to make some basic services available to women trying to negotiate a violence-free life for themselves and their children. These include emergency and long-term housing; legal advocacy; financial assistance, or access to employment, or both; a place to talk with other women and help to understand the social and personal forces in their lives; medical care; an opportunity to work in advocacy projects with other women; and community services that support women's roles as parents.

\section{(6) Intervening Directly with Abusers to Deter Violence}

For me the biggest shift was thinking about how to directly intervene with the man doing the violence. Do we try to fix him? When do we want to push for jailing batterers? Jails are not exactly places where men learn to respect women. I don't think we can claim to be standing with women if that means we say we're with you, except we won't ever deal directly with the person beating you up. On the other hand, trying to individually fix every man who beats his wife is futile. This is a tough one because as soon as you start to say, "OK, let's do something with these men," all sorts of screwballs show up to get in on it.-Legal advocate (interview, May 20, 1995)

A coordinated community response to domestic violence needs to establish a consensus regarding the responsibility of state and community agencies regarding an abuser. As the violence is understood to reinforce unequal gender arrangements in society rather than the manifestation of individual pathology, this responsibility must be assumed by the relevant social and legal institutions and community organizations rather than left to individual women. Many community projects therefore engage in direct intervention with the abuser, usually through three courses of action: (1) creating a safety plan for the woman, which may include such strategies as obtaining restraining or other court orders on the abuser; (2) imposing sanctions and deterrents, such as arrest, incarceration, and mandated community service, aimed at the individual abuser and at the broader community; and (3) providing abusers with an opportunity for rehabilitation. This last component is contentiously debated-there is little evidence of the success of these programs. Rehabilitation programs are usually run by mental health practitioners. Many advocates argue that rehabilitation programs typically de-politicize and de-criminalize the problem by psychologizing male violence in ways that make neither individual men nor unequal gender arrangements in society responsible for the violence. 
There is no agreement among intervention projects in the U.S. about the position or role the battered women's movement should take regarding rehabilitation programs for batterers. Most see monitoring such programs as part of their advocacy function. While some battered women's advocacy projects were drawn unwillingly into working with batterers, others were enthusiastic about their involvement. One of the major mistakes made by U.S. activists has been our failure to offer alternatives to rehabilitation taken up by the mental health movement. Despite early research which shows that highly structured education groups produce lower recidivism rates than groups using a more clinical, process approach with abusers, most batterers' groups are located in mental health centers rather than community-based education programs (Edleson \& Syers, 1991). The failure of activists to successfully argue that rehabilitation or re-education programs for batterers should be located in community-based education programs has had longterm effects on the battered women's movement. The DAIP argued for using an educational approach using Paulo Friere's literacy and popular education process because it emphasizes the cultural aspects of working with an individual and links the individual to the social relations active in their lives (Pence \& Paymar, 1993). ${ }^{16}$ However, nationally the trend has not been to locate projects working with batterers in a community-based educational setting. Instead we are now enmeshed in two powerful social institutions, the law and the mental health establishment. They share many of the same ways of conceptualizing the practice of "wife beating" (Pence, 1992).

\section{(7) Undoing the Harm Violence to Women Does to Children}

Somehow the children are always labeled as the innocent victims of battering. I suppose that means their mothers aren't so innocent. The system needs to see that when a man beats a woman in front of her kids, there are two innocent victims. It's so artificial to separate out - this is a child protection issue and this is a criminal court issue. No matter what, mothers come with kids and kids come with mothers. - Visitation center worker ${ }^{17}$ (interview, September 20, 1995)

\footnotetext{
${ }^{16}$ In 1990, activists from 40 states spent 6 days with Friere in Duluth to discuss applying popular education methods to working with batterers and with women who are battered. Had the model proposed by the DAIP gained larger influence across the country, the influence of the "psy" professions I discuss in chapter 7 would perhaps be less dominant.

${ }^{17}$ Visitation centers are sites at which non-custodial parents who have used violence against their partners can visit with their children.
} 
The success of advocacy projects in improving community and court interventions in domestic assault cases has not yet been matched by a similarly coherent approach to the visitation and custody issues which usually accompany the end of a relationship in which there has been violence (McMahon \& Pence, 1995). Children who witness violence in their homes are also its victims. When an abused woman leaves a violent partner, therefore, issues raised about children are not simply those of custody, but of responding to the totality of harm violence has done to the children. Advocates argue that the community, rather than individual women, has the responsibility to respond to this harm.

For women who have been battered, separation from an abuser often shifts the site of the conflict from the privatized setting of the home to the public arena of the judicial system. Custody and access workers report that abusive men are more likely than non-abusive men to fight for physical custody of their children (Taylor, 1993); evidence suggests that they are also more likely to receive favorable rulings from the courts (Saunders, 1992). Children and child custody issues are now a significant part of the politics of gender. Cain and Smart (1989) and Pollock and Sutton (1985) argue that a violent man's relationship with his children entails a power relationship with the children's mother, played out through the issues of custody and visitation.

Community intervention projects can play an important role in protecting children from violence, distress, and harm as their primary relationships are re-ordered. One cannot think about children or the "best interests of the child" as if children stand alone and are not integral to the power relations of which violence against women is part. To protect children and undo the harm done to them by domestic violence, community intervention projects and legal advocates argue that the mother's and child's interests must not be pitted against each other. The response of the system must be informed by an understanding of the role violence and power play in shaping the social relationships of families.

(8) Evaluating the System's Response from the Standpoint of the Victim It's important to agree on the standard that we will use to judge our work. If it's more arrests or more prosecutions or a speedier process, we may find a successful project that's failed to improve women's lives. We need to use what's happened to the women who are being beaten as the basis for judging ourselves.-Prosecutor (interview, September 20, 
Finally, a successful community response to domestic violence needs to establish the means to evaluate state and community interventions from the standpoint of women seeking protection. This standpoint must be contrasted with a standpoint of effective case management or a "lawand-order" perspective that measures success in terms of arrests, conviction rates, and incarcerations. Perhaps because it allows them to speak with "authority" to the voices of authority in the U.S., most criminologists in the U.S. are wedded to using quantitative research methods that are inadequate for addressing the problem of domestic abuse. ${ }^{18}$ Most of their quantitative research offers activists little to deepen our understanding of the social relations that support violence against women or remedies that would be useful to women who struggle to stop the violence. Both the strategy used to protect victims from violence and the means used to measure their effectiveness must be grounded in women's experience, not in the priorities of the organizations that manage domestic violence cases or in the perspectives of the professionals who organize community responses (Busch \& Robertson, 1992).

\section{Conclusion}

Generally speaking, the activities that constitute the work of legal intervention activists and projects such as the Duluth DAIP can be described within one of these eight categories. I do not mean to suggest that all projects have clearly articulated these activities as objectives, nor do I want to limit the activities that can be thought of as institutional legal advocacy. On the contrary, I suggest that institutional change cannot be limited to organizing an interagency policy council to improve arrest and prosecution rates, nor to creating a plan which centralizes a batterers' treatment program, nor simply to better coordinating a fragmented system. It must operate at many critical levels of change from the consistent standpoint of making women safe from continued abuse. In the next four chapters I explore the role of texts in the processing of criminal cases and propose an advocacy approach that inserts attention to victim safety into the daily work routines of court practitioners.

\footnotetext{
:The National Clearinghouse for the Defense of Battered Women publishes an annual summary of the most significant research in the area of women abuse. Of the 21 studies that focused on criminal justice reform work summarized in the 1995 edition, only one qualitative study was mentioned.
} 


\section{CHAPTER FOUR \\ INSTITUTIONAL TECHNOLOGY, JOBS, AND SPECIALIZATION}

Workers in the criminal justice system are typically organized to work on cases in very specific and standardized ways. Actions are coordinated both through the design of the practitioner's working space and through the establishment of standardizing documentary practices performed throughout a sequence of actions that culminate in case closure. Some practitioners, such as dispatchers, always operate from the same work setting, the dispatcher's console. Others, such as police officers, might perform several different tasks on a specific case, operating from a variety of sites, including the squad car, the booking room, the police station, and the home of the offender and victim. In this chapter I first discuss how the organization of the work setting is designed to influence the way individual practitioners act on a case and then show how a case is processed through a sequence of documentary practices that we might think of as processing interchanges.

Processing interchanges are organizational occasions of action in which one practitioner receives from another a document pertaining to a case (e.g., a 911 incident report, a warrant request, or a motion for a continuance), and then makes something of the document, does something to it, and forwards it on to the next organizational occasion for action. It is the construction of these processing interchanges coupled with a highly specialized division of labor that accomplishes much of the ideological work of the institution. Workers' tasks are shaped by certain prevailing features of the system, features so common to workers that they begin to see them as natural, as the way things are done and-in some odd way-as the only way they could be done, rather than as planned procedures and rules developed by individuals ensuring certain ideological ways of interpreting and acting on a case.

Work settings, routines, and the documentary practices used by practitioners to process a case constitute an institutional technology. ${ }^{19}$ The technologies of our jobs usually predate our

\footnotetext{
${ }^{19}$ Technologies shape the way we live and work together and what we are able to produce. Technologies are both the specific tools that workers use to accomplish their tasks and the institutionally organized procedures for accomplishing these tasks.
} 
employment. We step into a work setting with varying degrees of authority to change its character. The authority that individuals have to define their own jobs is based on several factors, including their position of authority in their agency, the rigidity of the institution they work within, and the type of work they do. However, in general, workers in the legal system, no matter what their position of authority, cannot alter the fundamental character of their jobs. A judge, for example, cannot independently choose how to conduct arraignment hearings or order for protection hearings. The proceeding will be marked by a particular judge's personality or judicial demeanor, but it will still essentially be what it is institutionally designed to be.

My investigation is based on a notion of seeing court processes as part of an institutional technology. To fully understand how the system is put together and functions requires more than simply being able to identify each of its component parts. If I were to take my lawn mower apart, carefully label each of its pieces, and draw a diagram of it, I would know a lot more about my lawn mower. But I wouldn't necessarily learn how it works. I might still not understand what makes the blade whirl to cut the grass. To mow the lawn I need only know how to put it back together, and my diagram will help me do that. But to make it do something different I need to see how it works; I need to see how each part operates and how it interacts with all the other parts. I also need to understand the principles of internal combustion. I need to understand the theory behind what I am observing. In this investigation I similarly attempt to discern how pieces of the technology are put together and how it is that they work together to produce certain institutionally authorized courses of action.

\section{The Design of the Work Space}

When I walk into the office of the agency at which I work, I enter through the reception area. Two women share the position of receptionist. Jodie works mornings and Jackie works afternoons. I've heard Jodie describe her job to others by saying, "I work the front desk." On her desk are four trays marked "Outgoing mail," "Incoming mail," "To be copied," and "To be faxed." To the right of her desk is a phone with fifteen buttons (mine has four); behind her is a computer; to the right of that are the agency mail boxes for each employee (except for her and Jackie); and a few steps away are a fax machine, a postage machine, a scale, and a copier. The file cabinet to the left of her desk stores copies of the articles and descriptions of the materials 
and programs that callers most frequently request from us. On the wall in front of her desk is an "in and out" board listing the names of all the staff members (followed by the names of the dogs of four staff workers who bring their pets to work on occasion). Next to that is a large twelvemonth calendar which lists all the trainings coming up, the name of the staff person assigned to conduct each training, and the city in which it will be held. On her desk is a sign, "Kindly leave your junk on your own desk." The posters on the wall are not of the receptionists' choosing but instead reflect the politics of the agency. One poster shows Desmond Tutu hugging Winnie Mandela; another is a map of the U.S. identifying the names and location of hundreds of indigenous tribes in the fifteenth century.

The receptionists' work setting tells a lot more about their job, the tasks they are expected to perform, and the questions callers ask than does the title "receptionist." This work setting is designed to let the receptionist efficiently respond to callers, to let her know who is in the office at any given time, to enable her to immediately send out brochures on trainings conducted by the agency, to let her know when and where the next training on legal advocacy will occur, to ensure that she will be the first to talk to a visitor. She is tied to the phone, so anything she needs in order to respond to callers is located within reach of the phone. She cannot be expected to do things that require concentration. During the course of a given day, she never has a period of more than three minutes in which she is not interrupted by a phone call or by someone coming into the office.

Like Jodie and Jackie, workers in the criminal court system, such as police officers, probation officers, and judges, all have work settings that make available to them certain tools and resources to perform their tasks. These work settings are designed to make possible certain activities and to make other activities either difficult or impossible. The work settings of criminal justice workers are designed to orient workers towards a case, a case file, an event or incident, the task of proving guilt or innocence, the management of the case paperwork, and the priorities embedded in the legal system. Many levels of government and a number of distinct and autonomous agencies make up the legal system, and no one person is in charge of the dozens of practitioners who intervene in these cases. While each practitioner works within a hierarchical bureaucracy headed by a director, the institution itself has no equivalent of a hospital 
administrator or board of directors. There is no CEO of the courthouse. Within the legal system there are multiple sites of power, where interests competing for resources, control of administrative processes, and case management priorities are played out in the political maneuvering that is the substance of courtroom gossip and lunchroom conversation. This lack of a single point of hierarchical power does not mean, however, that practitioners or agencies within the system are free to act in whatever way they see fit to perform their tasks. A highly organized system of routines and processes governs how each task in this maze of procedures is performed.

As D. E. Smith (1990a) notes,

Textual realities are the ground of our contemporary consciousness of the world beyond the immediately known. As such they are integral to the coordination of activities among different levels of organization, within organizations, and in the society at large. . . . Depths and complexities of the social organization of ruling interpose between local actualities and textual surfaces. Still, textual realities are not fictions or falsehoods; they are normal, integral, and indeed essential features of the relations and apparatuses of ruling-state administrative apparatuses, management, professional organizations, the discourses of social science and other academic discourses, the mass media, and so forth. (p. 83)

A work setting is designed to standardize key aspects of a worker's activities. Specifically the work setting is organized to ensure that certain information is made available to the worker, to ensure that the action the worker takes is institutionally authorized, to standardize how and what the worker produces in the way of information or reports, and finally to ensure that the appropriate people receive the information needed to continue processing the case through the system.

Institutionally Accessible Information and Resources

One feature of a work setting is the way it is constructed to make information available to the worker. Access to information is a key determinant of the way a given practitioner goes about doing a job. The availability of certain information and resources has significant implications for what gets worked into the case. If we think of the dispatcher as occupying the first in a series of work settings, we can see how its design becomes a determinant of practitioner actions. In Duluth, dispatchers work in a communications center situated about ten miles from the Duluth 
police department. The center is housed in a partially renovated building amidst the ruins of an abandoned U.S. Air Force base. It is in a remote area. Workers there dispatch emergency services for all of St. Louis County, which is the size of the state of Delaware but has a population of only 200,000 . They dispatch fire, police, and ambulance services, sitting in a large circle at computer stations with their backs to each other. In the center of this circle is a huge lazy Susan-like resource center containing maps of each town, back road, creek, and river in the county, manuals on resources by geographic and problem area, instructions on emergency medical care, descriptions of the habits of bears stuck in trees, procedures for responding to chemical spills, and information on fighting all types of fires, from grass to gas.

The dispatcher has a computer console linked to the patrol squads via a mobile data unit situated next to the driver of the squad car. This system, computer aided dispatching (CAD), allows the dispatcher to quickly retrieve certain institutionally owned data on residences and citizens.

Dispatchers can pull up on their computers a listing of all of the emergency services dispatched to a given address in the past 12 months. That record is a document institutionally accessible to the dispatcher, who therefore has more information regarding a case than what is offered by the caller. The nature of the state's response means that the woman who has been beaten and dials 911 is not calling another community member for help; instead, she calls into a system in which the dispatcher responds not as an individual but as an institutional worker. Thus the dispatcher is organized to treat the caller as one source of data, not as a co-actor in the process which is about to occur. This is a one-way communication system, one in which the woman has no active voice. She becomes a source of information that will be used selectively to make decisions crucial to her safety. The institution's data bank is another source of information. It allows the dispatcher to communicate information to the responding squad that would not otherwise be available to the officers, such as whether there is an outstanding local warrant or current order for protection on any of the parties known to the dispatcher.

The data base and technology used by the St. Louis County dispatch center precludes dispatchers from being able to inform responding officers about arrest warrants or protection orders from surrounding areas. The county lacks the resources and state-of-the-art computer technology to make this information available to dispatchers. Thus the design of the work setting does not give 
the dispatcher institutional access to this information even though it is information which is relevant to the safety of the woman calling for help. ${ }^{20}$

A second defining feature of a work setting is the tools available to practitioners to produce their work. For example, police officers are required to write several reports during the course of a 12 hour shift. Some calls result in three or four separate reports. All police reports are based at least partially on institutionally accessible information and all are made on forms designed to standardize the reporting procedure. But reports produced by officers using Dictaphones and then transcribed differ significantly from those produced on the same forms in the officer's own handwriting. In Duluth, the recent introduction of dictation machines has resulted in a significant increase in amount of the information officers record on a call, as several officers note:

I've gotten this dictation thing down pretty good now. I can take a few notes at the scene and as soon as I have a quiet moment I just talk it all in there. I used to write these things out longhand and I am the world's worst speller so I'd spend more time trying to think about what words I could use that I'd spell right than what I needed to say. I'd keep it short and sweet. Just enough to let them know what happened and why I did what I did. (Interview, July 17, 1995)

I write more now, but for a while I wrote less. The change was difficult because a lot of us had a hard time adjusting to the machines. Once we got some training and some formats to use, though, it got easier. I think most of the guys are-excuse me, guys like meaning both men and women-anyway, most of us are using the machines now. You're always going to have a few diehards that just won't make the switch. (Interview, July 21, 1995)

I have been reviewing reports for years and I think there's been two major changes in the quality of reports. First, the use of dictating machines-officers include so much more detail than they did before. And second, more use of specialized report forms. Everybody wants reports produced in a certain way. Sometimes an officer will write the same incident up on three different report forms, one for the state, one for court, and another one for the BCA. (Interview, July 21, 1995)

\footnotetext{
${ }^{20} \mathrm{This}$ information is also relevant to officer safety and to the investigation of other crimes. I do not mean to imply that it is not available because domestic assault is "only a woman"s issue."
} 
The availability of certain technologies has implications as to how thoroughly, and how efficiently, workers can perform their tasks. These technologies are not neutral in their role of producing facts or accounts of events. Technology becomes a part of what it produces.

Finally, work settings are designed to make certain resources available to the practitioner. The police administrator below talks about his early days on patrol, when there was no sheiter and no arrest statute.

We would go in there and if the situation was bad and we couldn't talk the guy into leaving we'd often arrest him for disorderly conduct. A couple of times I know I just let the guy take a swing at me so I could haul him down to jail. It was scary leaving the women home in some of these situations, you knew the guy would be back and there was no shelter. He knew all the places we could bring her, her mother's or sister's, it just wasn't a good situation. (Interview, July 27, 1995)

A judge and police officer talk about the connection of time to safety.

Even the most conscientious judge can't make a good ruling when we have only a few minutes on these cases. We're luckier here than in the Fourth District [Minneapolis area] where judges have about one minute to deal with a bail hearing and three and a half minutes to hear a protection order and [there are] no pre-sentence investigations on misdemeanors.-Judge (interview, January 15, 1995)

A woman who gets beat up on a Friday night in the middle of the summer is going to get just the very basics from us. There are nights that I never get so much as a fifteen minute break. This might sound callous but if she gets beat up on a winter Wednesday I can do a lot more to help her. . . For one thing, if he's gone I'll go look for him.-Police officer (interview, July 27,1995 )

\section{Processing Interchanges}

No one oversees a case from its inception to its final resolution. No single person hand-carries it from one processing point to another. The case is routed. Interchanges are connected through routing instructions and procedures. Some of these connections operate quite smoothly; others do not. Some of them are critical to women's safety. The dispatcher, or in civil court, the clerk: is the first person in a long chain of responders to a domestic assault case. The station of each 
responder has built into its information-collecting and information-producing functions mechanisms that link the information into an overall case construction. It is neither the worker nor the woman who was beaten who moves from one point to the next in the stages of case processing; it is the case file. This file stands in for the woman who was assaulted, for her assailant, and for those who act to intervene.

From the onset of a case, the hooking-up process is crucial to centralizing safety. The dispatcher takes a call at a console with a computer that allows information regarding the call to be entered into the $\mathrm{CAD}$ system. A receiving terminal for that information is in each squad car and at police headquarters. The file created by this call is assigned an ICR (initial complaint report) number, which becomes the number officially assigned to all future law enforcement documents regarding this incident. If the same people are involved in a second incident the next evening, it will be assigned a separate case number, and each case will be processed separately until the prosecutor determines whether the cases will be combined for trial or plea-negotiating purposes. ${ }^{21}$ This system is responding not to the woman and man in the context of their ongoing relationship but to the event of a certain evening. As discussed in chapter 3 on the nature of an incident-focused system, the crime, which is a single act, not the abuse (a pattern of behaviors), organizes the system's response. The information recorded by the dispatcher is the first point of inscription in the system. The conversation between the reporting party, who is often the woman who has been beaten, is reduced to a few shor phrases and summarized in the coded language of dispatching:

DOMESW: domestic with a weapon-priority 1

DOMESP: domestic physical-priority 1

DOMES: domestic verbal only-priority 2

GOA: gone on arrival

ADVS: advised

The police officer receives this information on a computer screen, and a printout of all calls goes

\footnotetext{
"Plea negotiations are agreements between prosecutors and defense attomeys in which the prosecutor agrees to reduce charges and/or support a particular sentence in exchange for a plea of guilty. The defendant then waives the right to a trial.
} 
to the supervisor of the patrol unit at the beginning of each regular work day. Anyone else who wants to look at this information must request it from the police department or the dispatch center. Copies of the actual tape of the conversation between the police dispatcher and the caller are available only to the police, the defense attorney, and the prosecutor.

The substance of the conversation between the caller and the dispatcher is in effect not available to the supervised release agent who makes recommendations to the court on setting conditions of bail or on releasing a man who has been arrested for assaulting his partner. ${ }^{22}$ Nor is the dispatch record readily available to the judge who decides these matters. Following is an excerpt from a transcript of a woman calling 911 . It was not entered into the CAD system and therefore not available to the police, who might or might not have included it in the report used the next day at arraignment court to decide under what conditions the defendant would be released.

Caller: I think he's finally gone off his rocker. He's not even drunk and he's saying all sorts of wild things.

Dispatcher: Like what is he saying?

Caller: How he's going to hunt down my brother and my two uncles and how everybody that's ever helped me is going to wish they had just let me rot.

Dispatcher: Where are these people now?

Caller: They're back in Red Lake [Reservation, about 150 miles from Duluth], but he can find them, he's nuts right now.

As previously described, the dispatcher, who is oriented to the next step in the process, provides information to the responding squads that alerts them to the immediate safety of the responding officers and of the parties present. In this case the dispatcher did not include information about the threat, presumably because it did not constitute a present danger. This key piece of information about the ongoing safety of family members of the victim drops out of the process and is never again available to practitioners as they process the case. Below is an excerpt from the arraignment hearing which was held the following morning to determine the conditions of this defendant's release until trial. The supervised release agent addresses the court:

\footnotetext{
"While the supervised release agent could request a copy of the tape, it would mean delaving the case for a day and would create a backlog in the system, so it is rarely done.
} 
Your honor, Mr. James has no previous convictions or arrests for domestics or any other offenses. Except for two traffic violations his record is clear. I have not been able to reach Ms. LaPrairie this morning about a no-contact order, but Mr. James tells me that she has initiated contact with him since he was arrested, so. . .

The dispatcher is trained to select very specific information to record in the CAD system. She is communicating to the responding officer, not to practitioners further down the line in the intervention process.

Processing interchanges are designed to organize the information received by intervening practitioners and to institutionally structure the kind of information that is produced at each interchange. Almost all interchanges are structured by the required use of forms, administrative procedures, regulations, or laws which screen, prioritize, shape, and filter the information the worker uses to produce accounts, reports, or documents related to a case. The dispatcher's computer screen, the police officer's knowledge of what constitutes probable cause to make an arrest, the state law defining assaultive behavior, and the state sentencing guidelines are all typical determinants of what documents are produced at each interchange and more important, of how they are produced. These documentary practices play a role in mediating the relationship of the intervening practitioner and the people who are involved in the case as victims or offenders. The information that is communicated to officers by dispatchers becomes a part of the officers' assessment of the situation and a part of the report they will produce. In this sense, the dispatcher's documentary practice becomes a determinant of the police officers' report, generated at a separate work setting but linked to and shaped by previous interchanges. In chapter 6 I show how as dispatchers selectively communicate information to the squads and as they in turn selectively record that information in the police report, certain information given by the woman to the dispatcher is preserved and certain other information is lost. The police report becomes the central document in making decisions about the case and therefore its construction is key to women's safety.

\section{The Construction of a Police Report}

As with any text, the police report is shaped by the conditions of its production. When the police attend a call they do not have the equivalent of the dispatcher's computer screen. They carry a 
small notepad and record names, addresses, dates of birth, times, and a few notes for their narrative. They then dictate or write arrest reports sometime during the following 12 hours. The tapes are left at the end of a shift for a typist to transcribe. The typists produce a rough copy on all arrests for arraignment court at 9:30 the next morning of every working day. Investigative reports require several more steps and there is no rush to produce a copy for the court. Court dates and hearings are consistently the driving force behind the scheduling of work in the legal system.

Police reports, like all other reports considered by the court in these cases, are not the product of individual officers' idiosyncratic writing habits, although their writing skills do play a part in producing what would be considered a good report. Like all reports, it has a frame that holds it together. As D. E. Smith showed in her paper $K$ is Mentally Ill (1976), it is the framing device employed in discursive practices of different professions that accomplishes the ideological work of the institution.

\section{Framing a Police Report}

I recently spent a month in Vancouver working at a friend's house. She lives a few blocks from a fitness center, which I used on several occasions. I had just joined a fitness center in Duluth with my friend Tineke, and we had been working out together everyday before I left. I had been trying to persuade a co-worker, Coral, to join us in our exercise routine. Coral had gained twenty pounds over the past several years and I was trying to convince her to come with us to the fitness center to work it off. She was reluctant to go because she didn't want to exercise next to a bunch of thin people. But my fitness center is part of a hospital where the majority of the clientele are hospital employees or patients recovering from all types of illnesses and operations. After I had gone to the Vancouver fitness center several times I sent each of them an e-mail about my discovery. Tineke's read:

There is no treadmill so I'm using the Stairmaster. It is quite a bit harder. There are also a lot more weight-lifting devices so I'm getting into muscle building. This will undoubtably change my routine when I get home. They only have one rowing machine and I have to wait to use it . . . it isn't as nice as the ones at our place. This place is part of a community center. It's just a few feet from the library that I'm working at and just one block from the 
sushi place I go to for hunch everyday. ... I couldn't have found a better place to do my writing.

That same day I wrote to Coral about the same fitness center. Her e-mail read:

Well it's not like Miller-Dwan, where there are lots of people with big bodies. This place must be some kind of a meeting place for the young, thin, and restless. I finally found out what time the old folks come and I'm planning to join them. It makes me appreciate MillerDwan.

Tineke's e-mail was framed by my relationship to her as a user of a fitness center, Coral's by my relationship to her as a sister who understands her reluctance to expose her body to "in-shape" people. This reader-writer relationship serves as a frame for the two very different e-mails describing the same experience. Textual frames are invisible but can be discovered in a text. Each text is framed by concrete methods being actively employed to produce accounts for the court. Discovering how a report is framed does more than simply expose an institutional bias. It shows the work of practitioners that has been glossed over and then links that work to the extended relations of ruling that determine work practices and in so doing organize local social relations.

I am specifically interested in how these frames shape the relationship of the court practitioner to the woman seeking safety. We have already seen that the administrative form creates interchanges and hooks various workers together while marginalizing or cutting others out of the connection.

In my police ride-alongs I asked officers how they decide when to write a report, how they decide what to record in their narratives, and how much leeway they have in making these decisions. Following are responses from several officers.

Well, that depends, by leeway I have none when it comes to deciding if I should write one. The state legislature has taken care of that decision. Basically if someone says they got popped I'll be filing a report. Some of it is a waste of time . . . but on the ones where you've got something, there is kind of a format to follow. 
First you summarize the case. I always dictate that last, but they type that in first. Then you kind of set the stage, you know, who was there, what was the fight about, what was the general situation, were people drinking, that kind of thing. Then you basically lay out what you had as far as the elements of a crime, was there a statement that someone inflicted harm on another, was it intentional, does the story match up with any of your observations. So, say she says he busted up the house but the place looks perfect, I write that up. If there's furniture laying around or broken lamps, doors etcetera, I put that in. .. I'm looking for something that will back up what either party says ... and I suppose I'm looking for something that would question what they said. ... If I'm going to arrest I have to be sure everything is there. Do they live together or have they ever lived together, did the assault happen within the last four hours, did it happen in Duluth. That last part is sort of a conclusion saying what you did.... We've had a lot of training on report writing so most of us have it down. There are some of the old timers that don't want to use the dictating machines but for the most part the reports are pretty professional. They pretty much have to be decent or it'll get kicked back to do over. (Interview, July 17, 1996)

I'm looking for the elements of a crime ... was there infliction of bodily harm or the fear of bodily harm ... was there intent ... did the person knowingly commit the offense. (Interview, July 16, 1995)

Both of these officers point to the criteria used to convict a person of assault under Minnesota law as the primary device framing their writing.

The police report is arguably the most influential document in the processing of a domestic assault-related court case. Here I am not simply referring to a criminal assault case, but to all the other legal proceedings a police report hooks into. Although the intended reader of the police report is the prosecutor, the report is used by almost every practitioner involved in the case, as shown in Figure 3, Multiple Readings of a Police Report. Police officers responding to a domestic disturbance call become the system's official observers of the situation. 


\section{Headquarters}

Is report complete?

Was there probable cause?

Is further investigation needed?

Rehabilitation Program

What happened?

How violent is the offender?

\section{Pre-Sentence Investigation}

What happened?

How serious was this incident?

Does defendant need alcohol

drug abuse evaluation/treatment?

Jury

What is the evidence?

Is defendant guitty?

Defense Attorney

What advice should

client be given?

\section{DAIP}

Is the suspect currently in program? What information is to be entered into the computer tracking system?

\section{Women's Coalition}

Where can victim be located for follow-up advocacy? What are safety concerns for victim?

\section{City Attorney}

How should this case be charged? Do I negotiate a plea agreement? How solid is the case? Are there witnesses? What is the priority of this case?

Supervised Release Agent

What conditions should be set for pretrial release?

Child Protection

How serious was this incident?

Are services needed for children? 
Each of these practitioners reads the report with a different intent. The detective bureau reads the report prior to arraignment in order to determine if the officers have correctly charged the suspect. If, for example, the person has been convicted of a previous assault within the past 2 years against any other person, even a relatively minor act of violence will be charged as a gross misdemeanor. As the seriousness of an offense increases, so do police efforts to strengthen the prosecutor's case by gathering more complete evidence.

The production of the text is framed by the institutional tasks of the next practitioner to take it up. Here the report is written with a prosecutor in mind, but it is then taken up by others with quite different purposes. The probation officer, who won't read the report until after a defendant has been found guilty by the court, is looking for aggravating or mitigating circumstances relevant to a sentencing recommendation. Two examples of probation officers' oral reports to judges follow. Both are based on police reports.

Your Honor, I believe that the situation here calls for a deviation upwards because of the fact that the assault included the defendant throwing a pot of water off the stove and he had no way of knowing how hot that would be. The stove was on so he could have caused grave bodily harm. In addition the report indicates that Mr. Slater pushed Ms. Gafney's ten-year-old daughter out of the way to get out of the house and he admits to that, Your Honor, so we really have two assaults here.

This case is a bit unusual, Your Honor, in that Mr. Teil has no contact with the victim and had not seen the victim for almost a year prior to this incident. According to the record Mrs. Teil asked him to come over and get his belongings from the home. Mr. Teil was apparently reluctant to come over without a third party present, which according to the report is why his brother was with him that evening. . . . I was unable to contact Mrs. Teil so I only have her statements to the police.

Because the frame these officers use to write their report is the elements of a crime, the probation officer has limited access to information about the context of the violence and therefore does not have much to say about it to the court. Much of what actually happened is not made available to practitioners in diverse settings as they take up the report in their specialized tasks of case processing. The particulars that the officers are organized to select and record are embodied in a language that is distinctly police talk. Child protection workers, divorce attorneys, and advocates 
for battered women will all attempt to apply the police officers' version of what went on to their functional tasks in the system. This version is rendered by applying a template of documenting the elements of a crime. If a child protection worker wants to get a sense of the harm done to the woman during the assault, she has access only to what the officers observed while establishing whether there was probable cause to arrest. But when using the frame of elements of a crime, officers are looking for injury, not harm. Injury is the condition which activates the police policy requiring officers to arrest.

Officers' comments are descriptive of what they saw and what they observed as the victim's physical state (for example, impaired vision or difficulties walking or speaking). In none of the more than 200 police reports that I read did an officer ever ask a woman to describe the pain she was experiencing. Others' access to information is confined to the boundaries set by the schema which provides a template for police reports on domestics. The information in the report is about the woman but not from her.

Key Processing Interchanges in Criminal Domestic Assault Cases

There are dozens of actions taken on a domestic assault case from its inception to case closure. Each of these actions constitutes a processing interchange. Figure 4 is a chart of the most significant processing interchanges occurring in a criminal misdemeanor assault case in Minnesota's Sixth Judicial District. Several more steps exist in processing a gross misdemeanor or felony case. These additional steps provide safeguards for the defendant, who if convicted faces the likelihood of incarceration through a proceeding which pits the individual against the more powerful and well-resourced state. The chart is followed by a narrative which explains in broad terms the purpose of each processing interchange. 


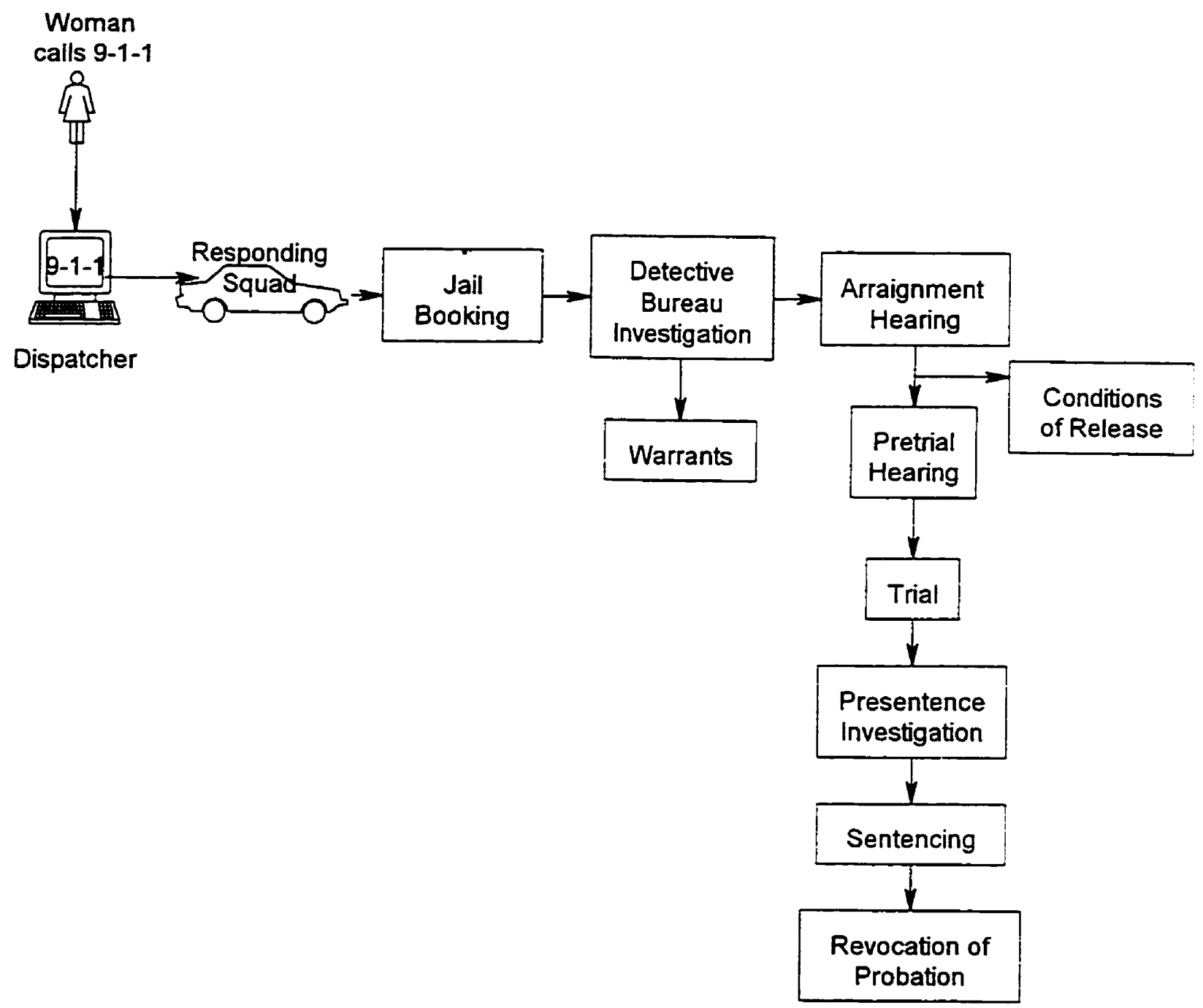


Typically a domestic assault case enters the system through a call to the 911 operator from a person being assaulted, a child or other family member, or a neighbor. ${ }^{23}$ The operator collects information from the caller and from the data bank at the communications center and transfers the information to the appropriate dispatcher, who electronically dispatches two squads to a call. ${ }^{24}$ Officers separate the parties and interview each alone. They then decide whether to separate them for the evening, mediate, or make an arrest. In Duluth, officers must arrest if they have enough evidence to establish that it is likely that one party assaulted and injured the other or if the suspect violated a protection order or used a weapon to threaten or harm the victim. ${ }^{25}$ If the offense included an assault with no observable injury, officers use discretion regarding arrest. If they make an arrest, they transport the suspect to the county jail and dictate an arrest report. If the suspect is gone at the time of the police investigation, the officers can issue a citation, much like a traffic ticket, or request that a warrant be issued for the suspect.

The jail holds the suspect until the arraignment the next working day, at which point the suspect is charged with the offense and becomes a defendant. The arraignment hearing has five purposes: (a) to charge the defendant; (b) to ensure that the defendant is represented by counsel if he so desires; (c) to allow the defendant to make a plea; (d) to set conditions of release should the defendant plead not guilty; and (e) to set a date for the next court appearance, the pretrial hearing. The pretrial hearing for a misdemeanor is typically held within 30 days of arraignment. ${ }^{26}$ The defendant has the right to post bail and can request that in lieu of bail he be placed on supervised release, through which he is released from jail and assigned to a probation officer during the pretrial period. A supervised release agent of the probation department interviews the defendant, makes one attempt to call the victim, reviews the defendant's criminal record, and makes a

\footnotetext{
${ }^{23}$ Forty percent of calls are placed by the victim, 15\% by other family members. (Interview with dispatch supervisor, June 11, 1994.)

${ }^{24}$ The Duluth Police Deparment assigns one officer to a squad and so dispatches two squads to all calls that may pose a threat to an officer.

"The City of Duluth was the first in the U.S. to establish mandatory arrest policies for domestic assault and as such is recognized as a leader in the reform efforts discussed in chapter 2.

${ }^{26}$ In $96 \%$ of domestic assault-related cases the defendant pleads not guilty at arraignment. (Interview with coordinator of the Domestic Abuse Intervention Network [the interagency data collection and distribution system described in chapter 3], March 21, 1996.)
} 
recommendation to the judge regarding his suitability for supervised release. The judge sets bail, offers to place the defendant on supervised release, or releases the defendant on his own recognizance, without bail or supervising agent. The judge may, at the point of release, issue certain orders effective until the trial is over, including ordering that the defendant have no contact with the victim, surrender his weapons, remain alcohol free, and remain in the county. The purposes of these orders are to ensure public safety and the defendant's appearance in court.

The pretrial hearing is the point at which the prosecutor shows the court and the defense (the defendant and his lawyer) the evidence the state has that the defendant committed a crime. It is typically the time when the prosecutor and defense attomey try to negotiate a settlement to the case without a trial. If the case is not resolved through negotiation then a trial date is set. Prior to this date the victim is subpoenaed as a witness and typically contacts the prosecutor asking that the case be dismissed; according to the Duluth chief prosecutor, more than $90 \%$ of victims request that charges be dropped or tell the prosecutor they don't want to testify (interview, May $8,1996)$. Three percent of domestic assault cases in Duluth are dismissed, $36 \%$ are resolved with a guilty plea to a reduced charge, $52 \%$ are resolved with a guilty plea and no reduced charge, $5 \%$ are deferred, and $4 \%$ go to trial (Domestic Abuse Information Network (DAIN) coordinator, interview, September 18, 1996).

If the defendant at some point pleads guilty or if he is found guilty at a trial, the judge orders that a presentence investigation (PSI) be conducted. The PSI provides the basis for determining an appropriate sentence. A misdemeanor PSI takes about an hour and occurs on the same day as the trial or pretrial disposition so that the defendant is sentenced immediately. It consists of an interview with the offender, a review of materials supplied by the victim or victim advocate, a phone call to the victim, a review of the police report, and a records check for prior offenses.

The probation officer returns to the court and makes an oral recommendation to the judge. ${ }^{27}$ The judge imposes a sentence of up to 90 days in jail, 6 months to 2 years of probation in lieu of

\footnotetext{
"This process is more detailed in felony cases. In some jurisdictions PSIs are not conducted on any misdemeanor offenses because of the volume of cases.
} 
jail, ${ }^{28}$ a fine of up to $\$ 1,500$ (or community service work in lieu of a fine), or a combination of these. If the defendant is placed on probation (most are), his conditions of probation may include attending counseling for abusers, abstaining from alcohol, submitting to a urinalysis test at the request of the probation officer, having no contact with the victim (if the victim requests this, although at the misdemeanor level, most don't), surrendering his weapons, and checking in with the probation officer one to four times a month.

Once sentenced, the defendant is either incarcerated or placed on probation; a defendant on probation must sign a probation contract which specifies his conditions of probation. The probation officer notifies the counseling program of these conditions, sets up a monitoring agreement with the program, and sets up a schedule for the payment of a fine or, for indigent defendants, a community service program.

The probation agent monitors the defendant's compliance with conditions of probation and brings the case back to the sentencing judge for revocation of probation if the defendant fails to comply with the terms of his contract. (Of course, this is in the ideal world.) Probation officers have broad discretion as to which cases they bring back to court for a violation of condition of probation.

This is a very general description of the processing points of a misdemeanor case. At each point there may be several other processes, such as the processes used to issue a warrant, to book and incarcerate a suspect, and to initiate a revocation of probation. At each interchange an institutional opportunity to account for victim safety exists. However, the criminal system is designed to process cases for the purposes of determining whether to charge and prosecute a suspect of a misdemeanor or felony crime and how to proceed with a trial or negotiated agreement that meets the state's goals. Issues that are specific to certain kinds of crime, as victim safety is to domestic assault-related crime, are not central to this design. The problems due to a lack of specialized routines which account for victim safety are significantly compounded by the

\footnotetext{
${ }^{23}$ A judge can put an offender on probation for less than 6 months, but this rarely happens. However, on August 9, 1996, the Associated Press ran a wire report of a Pennsylvania judge who piaced an offender on probation for 5 minutes for seriously assaulting a man he found in bed with his wife.
} 
highly specialized work force that carries out the activities depicted in Figure 4.

\section{Specialization and Safety}

I'm working at a friend's house today. When I look around her kitchen, I can't see a single thing that was produced by the labor of just one person. Even this dissertation is the work of many people. A co-worker is making my penciled diagrams into polished figures ready for publication; my advisor and true friends will read this several times, pushing me to make the next connection; my friend Kate will rid it of dangling participles, misplaced modifiers, and run-on sentences. My friend Shamita has offered to help me format my footnotes properly, and I'll never even meet the person who created spell check. We live in a society with a highly specialized work force.

This specialization has the effect of allowing large numbers of criminal cases to be disposed of fairly efficiently. It also allows practitioners to specialize in some aspect of legal work, which is crucial in a complicated and endlessly regulated field. Most of the people I talked to during this investigation became well versed in their jobs within 6 to 12 months. Still, the full impact of this specialization also has its drawbacks, particularly in cases in which there is an ongoing threat to someone's safety or health. The charts in Appendix B show the degree to which the system has organized its workers in specifically defined tasks. In this system the context of how and when violence is being used against a woman easily drops away as practitioners orient their work toward specific processes and incidents rather than to the full case and its outcome.

The highly specialized work force of the criminal justice system results in practitioners developing a very narrow definition of what it means to accomplish their task and what it means to do so in a fair manner. During many of my interviews with practitioners in the system, the issues of faimess, ethics, bias, and objectivity came up. I asked almost everyone I interviewed what their role is in ensuring that the overall process is fair and that it results in the court taking protective measures for women who are battered. For the practivioners, the concept of fairness was closely linked to their specific role in the processing of a case. Very few people took the position of standing back and looking at the whole case. One probation officer talked about it in terms of equity. We were talking about the impact on a particular woman's safety when both she 
and her husband were arrested for assault. ${ }^{29}$ She pled guilty and his case was still pending. The woman had been beaten by her husband after she had thrown a bottle of vinegar at him, hitting him in the face during a fight over her decision to move out. He had been arrested twice before for assaulting her but hadn't been convicted either time.

I can't have a separate set of policies for men and women, so if I get a case in which the woman has kicked the guy, or scratched him, or punched him in the stomach, or like this gal threw something at him and she initiates that violence, I have to treat her the same way that I treat a man who assaults his partner or wife. (Interview, September 26, 1995)

A police detective referred to the many cases in which women call to have charges dropped and claim that they lied or exaggerated to the police the night of an incident.

My job is to figure out whether or not this person was forced to recant, or recanted on her own volition. If she was forced to recant, then I charge him with tampering with the witness. If she recanted on her own volition, then I charge her with filing a false police report or contempt of court. She can't have it both ways-she either has to tell me she was forced to recant or I charge her. . . . Oh sure, you could say that she recanted because she was afraid of some future outcome, but under the law, he has to directly threaten her in order for me to charge him with tampering with the witness. There's nothing in between. Either she recanted because she was forced to by him or she recanted for her own personal reasons. ... I'm not saying she doesn't have her reasons for recanting, and even good ones, but there are lots of good reasons to break the law. (Interview, July 26, 1995)

Another probation officer made the next comment during a discussion on how to treat battered women who use violence against their abusers.

I have to treat everyone who walks through this door the same. I can't start making distinctions between, "Is this guy a batterer?" or "Is this woman a battered women?" and if she's a battered woman I'm gonna treat her one way and if he's a batterer another. Everybody who walks through this door gets the same treatment. (Interagency meeting, September 7, 1995)

The following is an excerpt from a discussion about the responsibility of women to undo the

\footnotetext{
${ }^{29}$ In Minnesota a second charge of domestic assault is elevated to a gross misdemeanor. Many women are afraid to call the police again because if they used any violence in the attack they could be arrested and face an extended jail sentence.
} 
harm of men's violence to their children. A social worker who had recently conducted a custody evaluation for the court was grappling with the dilemma of choosing between the mother, who has been traumatized by the father's violence, and the father, who has not been traumatized.

I needed to decide custody in a family where the man has repeatedly assaulted his wife. Because of the abuse she isn't in good shape. She is chemically dependent and is not being a very good parent. He has a job, he's sober, and he's stable. I know that it's the violence that has done this to her. But given where she's at compared to him, how can I not give him custody? Even though I know it's not fair to her, isn't it fair to the children? (Social workers' meeting, April 5, 1994)

Finally, a police detective and a judge comment on the limits of what they can consider in a fragmented approach to processing cases.

I'm not so sure what you mean by how do I get involved in the whole case. That's not really my job, to get involved in the whole thing. I'm an investigator. That means I investigate. If I get to having a need to own a case I'll go crazy with all the nutty things that happen in this place. I do my job and I think I do a fairly good job, but I don't want to be held responsible for how the whole thing turns out. I've seen a lot of goofy things happen here and all I can do is say, "Did I do what I was supposed to do?"-Police detective (interview, February 15, 1996)

We can only base our actions on what the state was able to prove and unfortunately the nature of these cases, being what they are, they are difficult cases to prosecute. I can't sentence someone for all the things I believe he's done, I sentence based on what the prosecutor proved in court.-Judge (interview, June 7, 1995)

These comments confirm that no one is tending the outcome. The totality of the case gets lost as practitioners attach themselves to specialized processes. The question "Was this fair?" gets asked of each step in the case rather than of the process in its entirety.

Even when practitioners do step back and see how the process is detrimental to women's safety, there is often little they can do about it in a fragmented system. One of the detectives at the police department expressed the frustration that practitioners have with the sluggishness of a specialized work force and its implications for women's safety in these particular cases. He gave me a memo he had written a year earlier, when he sat on a committee to review case-processing 
problems in misdemeanor court. He had used the processing of a warrant in a domestic assault case to show one significant problem. He told me it was a fictitious case but said, "This case is not one bit exaggerated, in fact, no one on the committee disagreed with me that this would be a typical scenario on a domestic." Below is an excerpt from that memo.

Jan. 1, 1993, a Friday: A domestic between a cohabitating couple occurs in the city. The victim gets a black eye and bloody nose and calls the police. A sqd. responds and finds the offender gone and is not able to locate him within the 4 hours. They go back to their business.

Jan. 2: The sqd. dictates a report.

Jan. 4: The report is transcribed and returned to the Patrol division.

Jan. 7: The report is signed by the supervisor and taken to the traffic division where it is logged as a warrant request.

Jan. 8: It is placed in the city attorney basket. It is Friday.

Jan. 11: It is logged into the city attorney's office and sent to an attorney. Some time within the next couple of weeks, an attorney will review it, decide to issue, direct a clerical to fill out the necessary forms.

Jan. 25: The file is returned to the DPD Detective Bureau clerical person with a summons attached.

Jan. 27: The clerical types out the summons information and mails the package out, including all of the reports, the victim and witness information and statements.

Jan. 28: The victim and offender, having continued to live together, share the first day since the assault that they have not thought or argued about it.

Jan. 29: The offender opens his mail and notes that his court date is set for Feb. 22.

Feb. 22: He doesn't appear for court. At the end of the day, the court file is carried back into the Clerk of Courts offices.

Feb. 23: It is placed into a basket where it sits for the standard two week minimum grace period.

March 10: It is removed from that basket and placed into the "return to city atty for warrant basket." It may sit there until a stack "worth" picking up or mailing back over accumulates but to be charitable, lets say it goes within a couple of days. 
March 12: It is received in the city atty's office and sent to the issuing attorney.

March 17: It is dictated as a warrant and returned to the DPD.

March 18: Sgt. Nichols carries it to the court, swears to it and has it signed by a Judge. He then carries it into the Clerk of Court's office. There it is placed into a basket of complaints to be filed when they have time. This may take a week.

March 24: It is placed into the warrants basket to be picked up by the Sheriff's warrants office.

March 26: It is received into the warrants office, logged in, entered into the computer and placed into the basket for service.

March 27 and 28: The couple spends first weekend since his failure to appear, not worrying and arguing about what will or should happen.

March 30: He calls and agrees to come in the next day.

March 31: He appears and pleads not guilty. A jury pretrial is set for the first week of May (jpt's are always the first week of the month and he is now too late for April). April is a pleasant month for her, don't you think?

It seems to me that our only reasonable choices are to either do it right or stop aggravating the troubles these people have.

It is within a highly specialized bureaucratized system that criminal justice practitioners are occasioned to intervene in the lives of women who are battered by men. The adherence to one way of doing things occurs as practitioners are artificially constrained from working on a case from beginning to end. Instead, practitioners are given pieces of the cases and organized to limit their intervention to those activities relevant to a very specific task in the case processing. Most workers grow detached from the reality of what it means for a woman to live with someone who beats her. How power is being used to manipulate the woman or how the court's intervention is causing the offender to escalate in his violence is not accounted for in these documentary practices and is therefore not accounted for in the practitioner's institutionally authorized response. An overly specialized work force in the legal system creates a fragmented response and allows faimess and attention to safety to slip simultaneously through its organizational web.

Attempts at creating linkages through routing texts, rather than simply making them 
institutionally accessible, may have unintended consequences. For example, last year the Duluth Police Department began routing all domestic violence police reports that mention the involvement of children to the child protection unit of St. Louis County Social Services. This procedure did create a needed link between the police and child protection workers. However, it brought a new level of state intervention into the lives of battered women, which was problematic on several levels. One child protection worker described an aspect of these problems:

We started getting these reports every morning and then when we had our morning assignment meeting we' $d$ be given these reports. So I'd hop in the car and go out to talk to some of these women and bam, get the door slammed in my face. We weren't really sure what to do with them. You really couldn't tell from the report if there was a child protection issue or not, and I can tell you it wasn't very fun going out and asking these women if their child was OK after she had just gotten clobbered by her husband and regrettably got the police involved who regrettably got us involved. (Interview, June 14, 1995)

Unlike advocates, practitioners in the court system do not work with a woman throughout the entire process, nor do they work with her in aspects of her life beyond the particular case. Advocates deal with a woman's financial situation, her legal problems, her housing needs, her medical needs, her children, her divorce or custody problems, her need for coming to some kind of understanding of what has happened to her, and finally how she wants to maneuver her way through this legal process. Practitioners in the system try to accomplish very specific tasks. Much of what is attributed to victim-blaming attitudes or thinking in the system is directly linked to the roles that practitioners play in the processing of a case. These narrowly defined, specialized roles lead practitioners to view a woman as either cooperative and helpful in the processing of a case or as uncooperative and resistant. No one attempts to stop a process when it is in its entirety unfair, because no one has strayed from doing his or her prescribed task. No one is assigned the task of stepping back to see the whole, to consider the context in which these events have unfolded. One may argue that considering the context is the role of the judge, but the judge is the recipient of a case file that was constructed in these specialized and highly routinized settings. An overly specialized work force contributes to the distortion of practitioners' understanding of or accounting for the complexity of these situations and 
frequently prevents them from acting in a way that accounts for the many forces that are operative in a woman's life as she struggles to be free of the violence. By the time the case gets to the judge, the information needed to contextualize the case has been eliminated from the manufactured case file and replaced with a version of the case that is institutionally actionable.

\section{Mapping the System}

To understand the complexity of this system of managing cases, I have developed maps of each phase of case processing. Like the detective's memo, a map of the system begins to provide a glimpse of the points at which opportunities exist for institutional action-points at which victim safety is either ensured or compromised. The charts, which started out as a simple road map and now look more like an atlas, illustrate the way dozens of workers from different agencies and levels of government are brought into the case-processing routine as they are individually organized to act in sequential operations.

I have found it useful to organize the dozens of sequential operations into general phases of case processing. The first phase begins with the call to 911 and ends with the police charging or releasing a suspect. Within that first 12-hour phase of a one- to three-year process, there are over a dozen organizational case processing sequences. I've called that phase immediate intervention and initial investigation. The second phase begins as the court arraigns the suspect, beginning the processing of the offender as an alleged criminal. Crucial safety-related decisions are made at arraignment court, in the pretrial release investigation, in the setting of release conditions, and in the process of releasing alleged offenders. The third phase of case processing occurs as the police and prosecutor build a case in an adversarial system against the defendant and the case is resolved in a dismissal, negotiated plea, or trial. This is the case determination phase. The fourth phase of case management is determining what to do with the convicted offender. It involves presentence investigations, sentencing hearings, reports to the court, and a sentencing decision. The fifth phase is implementing court sentence: incarcerating the offender or putting him on probation and linking him into whatever programming has been ordered. The case then moves into the last phase, ongoing surveillance and actions following new offenses. Appendix $\mathrm{B}$, Immediate Intervention and Initial Investigation, is a flow chart of all of the major sequences in phase one. I want to show one of these sequences in the first phase of case processing in order 
to illustrate the many ways that victim safety could be acted upon in a case.

There are five major sequences in this phase of case processing. They are:

(1) 911 call and dispatcher response;

(2) police response and initial investigation including police action at same arrest, mediation or separation;

(3) booking and holding the suspect;

(4) filing a police report on an investigation; and

(5) follow up detective bureau investigation.

Figure 5 depicts the first sequence, the 911 call and the dispatcher's response. (The full series of charts appears in Appendix B.) 


\section{FIGURE 5: IMMEDIATE INTERVENTION AND INITIAL INVESTIGATION:}

\section{DISPATCHING SQUAD}

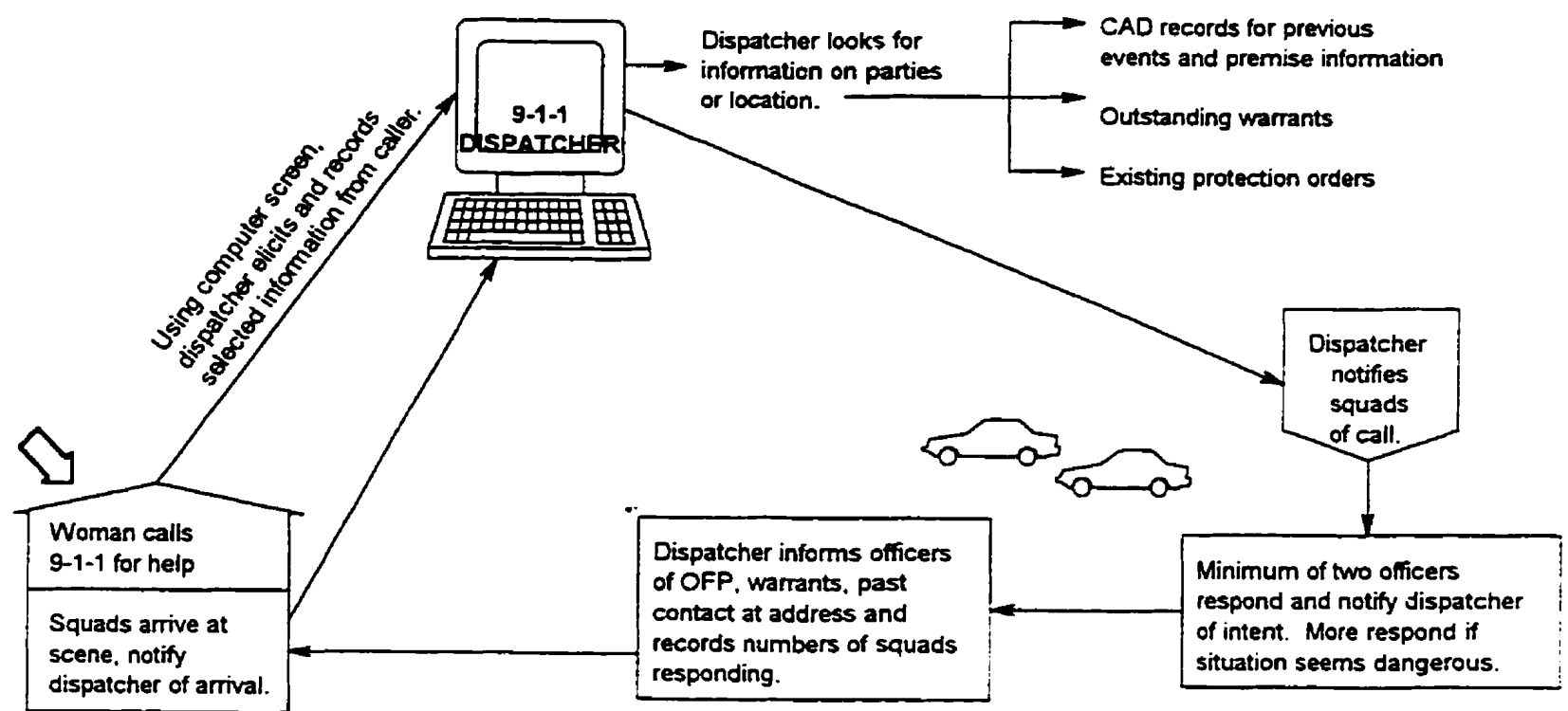

CAD - Computer Aided Dispatch

OFP - Order for Protection

on dispatch screen and

squad MDT is simultaneously

received on terminals at police

desk and patrol supervisor's

Police desk officer prints

MDT - Mobile Data Terminal

desk. ICR and summary of

information become the

out watch reports at

ICR - Initial Complaint Report

"watch report." 
These charts show an orderly mechanism for processing a case, but as the detective's memo points out, it is often irrelevant to the lived experience of the woman who placed the call to 911 in the first place. He knows that she may in fact be placing herself in greater danger by activating this whole response.

At each processing exchange an institutional opportunity to account for victim safety exists. However, issues such as victim safety are not central to existing documentary practices. An institutional investigation helps to determine how such an objective could be incorporated into the design at each of these occasions. An institutional advocacy program uses this investigation as the basis for setting the agenda for proposed reforms of the system. As will be explained in chapters 8 and 9 , the first step in accomplishing such an investigation is to create a map of the system, as I have begun to show here.

\section{Conclusion}

For the investigator, the work setting and processing interchanges become the units of analysis, the observation site. Action is taken at each interchange by a practitioner who is linked to others in the system, primarily through texts. The extended social relations among practitioners in the system, and between practitioners and the subjects of the criminal case (offender and victim), are textually mediated. The investigator is asked to follow the text. In the next three chapters I will follow the text to explicate how the extended relations of ruling that ideologically control these cases fail to attend to women's safety. 


\section{CHAPTER FIVE}

\section{A TEXTUALLY MEDIATED SYSTEM}

When I was a child I lived with my mother, three sisters, and brother on Winnetka Road in New Hope, Minnesota. Winnetka was a dirt road. It separated the houses built for returning soldiers and their families after World War II from the fields of corn, soybeans, and hay that spread beyond that point for as far as I could see. We had one phone (rotary dial) in our house. Taped to the wall above it was a red card identical to those taped to the walls in the houses of all my friends. At the top, in big letters, it read EMERGENCY NUMBERS. Below were three numbers-for FIRE, POLICE, and AMBULANCE.

I remember using an emergency number only once. I called the fire department because my brother had accidentally started our dog house on fire. The fireman who answered asked to talk to my mother. She was at work, so he called Mrs. Nelson, who lived next door, to see if a fire truck was necessary. Apparently it wasn't, because Mrs. Nelson came over and put out the fire with the garden hose.

I still live on a dirt road. But there is no red card in my home, because like almost all other citizens in my community, I know that in case of an emergency requiring the police, an ambulance, or the fire department, I need simply dial 911 . This number-911-is a universal text in the U.S., actively organizing the way in which the public enters into processes of management and ruling by community institutions.

Today if I call the designated emergency number, I won't reach a fireman, as I did when I lived on Winnetka Road. I'll reach a county employee. The management of public agencies which organize our social relations has become increasingly complex and bureaucratized. The county employee I will reach by calling 911 is an intake dispatcher, who will determine if I need an emergency service, which emergency service or services I need, the exact location of the problem, and the identities of those involved. This dispatcher will then electronically transfer my call to a second dispatcher, who will communicate with the appropriate emergency service to 
dispatch "help."

When a woman who has been beaten by her intimate partner dials 911 for help, she activates a complex system of agencies and legal proceedings which constitute the state's legal apparatus of ruling. It is in turn linked to other systems of ruling, particularly the mental health and social service systems. These agencies of social control are themselves coordinated and controlled through administrative processes and regulating texts increasingly present in the mundane but vital processes that manage our daily lives. Few activities that occur in the processing of a case are not textually mediated. Texts are the primary instruments of implementation and action in this system and as such are a focal point of my investigation.

The number 911 is the first in a series of texts that will coordinate, guide, and instruct a number of practitioners who will participate in processing as a criminal assault case a woman's experience of being beaten. The dispatcher who receives the call does not use her own discretion in accomplishing each of the tasks in this highly specialized system. She instead follows a written script in the form of computer screens which mediate the discussion first between the caller and the 911 intake worker and then between the dispatcher and the police officer who will respond to the call (Wahlen \& Smith, 1994). These screens constitute the second text in the management of a domestic assault case by a community's police and court system. They are not, as D. E. Smith (1990b) notes, "without impetus or power" (p. 122). These texts and the hundreds that will follow are active. They screen, define, prioritize, schedule, highlight, route, mask, and shape.

The "case," as a woman's actual experiences become when the dispatcher begins the process of inscription, is institutionally resolved through a series of processes or organizational occasions. Cases move from one occasion to the next through a series of practitioners who do something-take action-and then textually record those things needed to move the case to the next occasion for action. Much of what the practitioner does is guided by texts such as administrative forms, rules and regulations, screening devices, intake forms, and report-writing formats. The text the practitioner produces is designed to hook up and assist the practitioner at the next occasion for institutional action. As such the text, like the practitioner, is doing 
something. Between what happened to the woman the night she was beaten and the final organizational occasion lies a "social organization of ruling."

Much of the ideological work of the system is buried in the text. Therefore to incorporate a principle such as prioritizing victim safety into the infrastructure of the system, changes must occur at the level of the text. While I have contended that the battered women's movement has not had a very sophisticated understanding of the court system as a textually mediated process, I am not claiming that the movement has paid no attention to the text. It was battered women's activists who insisted on state laws requiring police to write investigation reports on all domestic assaults they investigate. It was also these activists who argued for a dispatching system that coded assaults on women separately from the general category of domestic calls, which includes any disturbance at a private residence-loud parties, cats stuck in trees, teenagers who don't come home at night. They have worked on committees to review state forms, court regulations, and welfare intake forms. I am, however, contending that we have placed far too great an emphasis on the personal attitudes and beliefs of individual practitioners, missing the processes that organize their responses, and arguably their consciousness, about these cases. Each entry into a case file represents a version of a lived experience. Each version has its own production story (Green, 1983). Activists have paid far too little attention to the way practitioners' daily activities are organized to produce the texts which both become the cases and determine case outcomes.

\section{Court File And Agency Case Files}

Institutions which manage citizens' private lives, such as the legal system, social welfare agencies, and mental health agencies, do so through paperwork. For a case to be handled by people in diverse settings, each with specialized tasks, a written record is kept. Each practitioner leaves an imprint on the case. The record moves from one component of the case processing to the next. Sometimes the people involved in the case are present to add their voices; sometimes the written record becomes the total representation of their experiences. But as D. E. Smith (1990b) contends, inscriptions do not just refer to events that occurred, they are in themselves doing something. They are working with the reader at different organizational occasions to accomplish different institutional tasks. 
In particular the formality, the designed, planned, and organized character of formal organization, depends heavily on textual practices, which coordinate, order, provide continuity, monitor, and organize relations between different segments and phases of organizational courses of action, etc.

Organizational texts order and coordinate the practices of dispersed organizational settings. Hence they will be read and interpreted differently on different organizational occasions. (pp. 217-218)

The legal system, like most institutions of social control, uses bureaucratic forms of management to accomplish its work. Relationships between individual citizens who are linked to a crime and workers in the legal system are organized through the creation of a case. A case record or file becomes a key organizational element in taking action; it is the institution's representation of the "incident" (here the incident is an assault on a woman) which precipitated the opening of the case. As an institutional representation, it reflects the concerns of the institution. It is like a medical chart telling the reader who did what, when, and for what purpose. Although some organizational occasions are recorded, case files rarely contain verbatim transcripts of what occurred. Instead they contain documents that are organized to record what "of institutional significance" occurred at each processing occasion.

Members of the institution are trained to read and write in institutionally recognizable ways. The reader is linked to the writer of a document in such a system not only through the text but through the legal discourse which organizes their professional training. Professionals are trained to translate what they see and hear and gather from the everyday world into professional discourses about that world. The professional discourse in reports and documents appears to be the objective work of an individual responding to a specific set of circumstances, yet this is far from what actually happens: battered women's lives are twisted into preformulated categories created not in the lived experience, but in the professional discourse.

This is not a process to which advocates are immune. As Gillian Walker (1990) shows, we have adopted many of these ideological representations of women who are battered and of their abusers. But more important, we have engaged in producing our own ideologies by adopting the 
conceptual practices of the professional discourse which individualizes social relations. The cycle of violence theory of feminist therapist Lenore Walker (1984) is perhaps the best example of movement activists embracing and promoting an ideological representation of women's lives. L. E. Walker's theory makes the dubious claim that almost all of the millions of men who batter their partners are experiencing a psychological response to stress and anger which reoccurs cyclically over an extended period and typically escalates in severity and frequency. Her theory proposes that this psychological response occurs in three phases: a tension-building phase, an explosion phase, and a respite phase. Even though thousands of women report the absence of tension-building or respite phases, and thousands of others experience low levels of violence for decades with no escalation in frequency or severity, her theory is widely embraced as descriptive of most domestic violence.

The law deals with cases. Cases don't exist in the lived reality on the night a man's fist smashes into a woman's face; cases exist in case files. Case files create a means for the many practitioners involved to act on a case in a prescribed way. A case file is oriented to a particular subject. The gathering of the data for the file is generally not seen as problematic. Entries are made by invisible, interchangeable people. The entries made by those who make the observations typically interpret the actions of the report's subjects, the man who beat his wife and the woman who was beaten, in terms of the legal process for which an entry is being made. A police officer records information related to the existence of the elements of a crime, the probation officer produces an account of a case in relation to sentencing objectives, and the rehabilitation worker documents indicators of amenability to change. Administrative forms, established ways of seeing things, and criteria established in policies regarding what is relevant information guide the recorder through the literally dozens of choices to be made. These guiding forces are invisible to the casual observer and make it appear as if practitioners are making individual choices based on the specifics of a case. Martha McMahon and Ellen Pence (1995) quote the following observation from a worker at a newly organized visitation center. It offers a rare glimpse of a situation in which the textual process is visible and not yet embedded in the setting. The production of a file (the visitation center $\log$ ) is still seen as embedded in the choices and activities of individual people. 
[After the visit] we make a note in the log if anything went on worth noting. It's that term "worth noting" that causes the problems. We've had so many discussions about what to record. These records have been subpoenaed by attorneys on both sides of really brutal custody fights. So we all feel uncomfortable about what to record.

We thought we solved the problem by agreeing to only record exactly what we saw. Still, just selecting which two or three things of the thirty things we've observed should be logged was a problem. Should we only comment on things the visiting parents do that are negative? If we put in the $\log$ "... he was always on time and respectful to us and his former partner and seemed to be attentive to the children's needs and feeling," what would be the purposes and use of this comment later in a courtroom when lawyers make their cases? (pp. 190-191)

Here the worker is part of a process which in just a few years will be invisible. She and her colleagues are trying to create a rule or frame for selecting the particulars of a situation. Later these recordings will appear as objective observations of what of relevance was there to be seen.

In order to investigate the documentary practices associated with processing a criminal domestic assault case I collected every available court and police document on six cases. ${ }^{30}$ I chose cases based on discussions held at the bimonthly interagency meetings involving probation officers, shelter advocates, and facilitators of men's groups. If a particular man's name came up at the meeting I noted it and began to collect files related to his case. ${ }^{\text {il }}$ I had planned to write a summary of each case and then analyze how the issue of victim safety was either incorporated into a case file or dropped from it. My plan was to then link the safety concerns in the file to the actions practitioners took as a result of these safety considerations. A co-worker helped me gather files. It took 20 to 30 hours over 2 weeks for two of us to gather all of the documents on just six cases. Even at that we were missing many documents. The court file was centrally located, but there were literally hundreds of related documents dispersed throughout the system in the agency files of individual practitioners.

\footnotetext{
${ }^{30}$ I selected specific cases only to have an entry point into what I am trying to understand as discursively organized relationships. I am not trying to establish a random sample or a look at a representative type of case.

"During the course of a week I attended two or three meetings with advocates or court personnel or DAIP staff in which the names of problem cases came up. I selected cases in which the problem seemed to be with how someone in the system responded rather than those that were problematic strictly because of the offender's behavior.
} 
When I had finally succeeded on getting one fairly complete file together I spent an entire day indexing each piece chronologically. It was confusing because the file documented four separate incidents of violence. There were in fact four separate cases covering more than 6 years, all in one court file. Having completed this unexpectedly time-consuming task, I sat down to read the file in its entirety. I wanted to figure out just what had happened to Debra Barber and the man who was beating her, Robert Barber. My indexing sheets on the Barber file follow. 


\section{ROBERT JOHN BARBER COURT FILE}

88-81543 OFP

$8 / 5 / 88$

Order for domestic abuse hearing and ex parte order for protection (along with Affidavit of Debra Barber)

8/5/88 Sheriff's information sheer

$8 / 13 / 88$ OFP

$8 / 13 / 88$

$8 / 14 / 88$

Court minutes-notes persons present at $8 / 13 / 88$ hearing

$8 / 31 / 88$ Letter to Judge Hersh from the court alcohol counselor go to counseling together" and believing he has changed and wants to be together as a family. (Set hearing for $9 / 15 / 88$ )

9/15/88 Order allowing Barber to reside in home and continued counseling of both parties by Reverend Sikes and reinstating remainder of provisions of $8 / 13 / 88$ order

12/14/88 Letter to Pierce (DAIP) from Lutheran Social Services re status of Barber

12/21/88 Petition for review/hearing and order by Pierce-hearing set for 1/12/89 (says Barber not cooperating)

1/12/89 Order ordering Barber to meet with Smith and Kent re counseling plan

1/12/89 Court minutes-notes those present at hearing

\section{CRIMUNAL CASE \#75843 ASSAULT IN THE 5th DEGREE OBSTRUCTING LEGAL} PROCESS WITH FORCE OR VIOLENCE

$9 / 18 / 88$

$9 / 19 / 88$

Arrest report of $9 / 17 / 88$ assault on Debra and cops

$9 / 19 / 88$

$9 / 19 / 88$

$9 / 30 / 88$

$10 / 8 / 88$

Criminal complaint

Public defender's eligibility form

Supervised release agreement

$10 / 8 / 88$

$10 / 16 / 88$

$11 / 12 / 88$

$11 / 12 / 88$

$12 / 28 / 88$

$1 / 26 / 89$

$1 / 26 / 89$

Prosecutor's notice of evidence and demand for disclosure per rule 9.02

\section{Letter to court by prosecutor confirming omnibus hearing has been reset for} $10 / 16 / 88$

$9 / 30 / 88$ to

$1 / 26 / 89$

Petition to enter plea of guilty in felony or gross misdemeanor case

Dismissal of count II of the complaint

Guilty plea to assault in the 5th degree; fined $\$ 100.00$

Summons to appear on $1 / 26 / 89$ to answer complaint alleging Barber violated terms of probation by failing to cooperate with DAIP (includes the Conditions of Probation form)

Notice of alleged violations to Barber by Arrowhead Corrections Transcription report

Transcribed summaries of all Barber's court appearances

K3-74-589241 OFP

7/25/92 Order for domestic abuse hearing and ex parte order for protection (along with Affidavit of Debra Barber)

8/1/92 Order for protection and court minutes noting persons present 
10/20/92 Notice of motion and motion by Barber requesting dismissal of OFP and restoration of custody of children. The affidavit asks for the modification of the OFP because "Religious beliefs specifically forbid separation of husband and wife"

10/23/92 Order to show cause (based on DAIP staff's affidavit) why court should not hold Barber in contempt of court for failing to make arrangements with DAIP and because DAIP staff saw them together on several occasions

10/23/92 to Sheriff's log with attempts at serving Barber with order. Also a photo of him and $10 / 28 / 92$

$11 / 7 / 92$

$1 / 15 / 93$

$1 / 23 / 93$

$3 / 7 / 93$

$3 / 17 / 93$

$5 / 8 / 93$

$5 / 18 / 93$

$5 / 21 / 93$

$5 / 28 / 93$

$2 / 3 / 94$

$2 / 3 / 94$

$2 / 3 / 94$

$2 / 12 / 94$

$3 / 15 / 94$

$3 / 15 / 94$

$3 / 23 / 94$

$4 / 9 / 94$ a note stating "ARMED"

Order holding Barber in contempt of court and sentencing him to 10 days in jail unless he complies with OFP dated 8/1/92 and denying Barber's motion to terminate OFP and court minutes

Notice of motion and motion by Debra to modify OFP so they can attend church together and go to marriage counseling

Order allowing the parties to attend church together and can attend marriage counseling upon Barber's completion of his remaining nine anger control sessions

Notice of motion and motion by Barber to modify OFP to permit contact and lift exclusion from the home "to renew our marriage"

Order allowing Barber in home with the 8/1/92 OFP as amended remaining in effect

Notice of motion and motion by Debra to exclude Barber from home

Motion by Debra to prohibit phone contact and allow visitation through Visitation Center. He came to house while they were gone, changed locks, put some things in garage, carries gun

Order forbidding Barber from being at or near the home and contact only in public in presence of third persons and parties are to arrange visitation through Visitation Center

Letter to Barber from DAIP Visitation Center confirming that Barber will no longer be using the visitation center

Memo and enclosures to Initial Intervention Unit form, court administrator's office re OFP

Order for hearing and ex parte order for protection (along with Affidavit of Debra)

Sheriff's information sheet

Order for protection and court minutes

Affidavit and motion to modify OFP by Debra asking for no phone contact and supervised visitation and mandated anger groups

Affidavit and motion to modify order for protection by Barber requesting custody of children and possession of house until Debra has undergone counseling for anger, then family counseling

Order continuing modification hearing until 4/94/94; prohibiting phone contact; arrange visitation through Visitation Center and reinstating rest of 1/12/95 Order and court minutes

Order granting Barber supervised visitation through $\mathrm{VC}$ and reinstating all other provisions of the 2/12/94 order and court minutes (copy of order to Barber 
7/21/94 Affidavit and motion to modify order for protection by Barber requesting unrestricted visitation

8/6/94 Order denying visitation because Barber is in jail and minors cannot visit inmates

8/7/94 Letter by Barber to Judge Adams stating that new policy of jail does allow minors to visit

8/21/94 Letter by Barber to Judge as above

SB-94-420680-CRIMINAL CASE SB-94-420680 BURGLARY AND VIOLATION OF OFP

$5 / 4 / 94$

$5 / 7 / 94$

$5 / 7 / 94$

$5 / 7 / 94$

$5 / 9 / 94$

$5 / 11 / 94$

$5 / 12 / 94$

$5 / 25 / 94$

$5 / 26 / 94$

$6 / 2 / 94$

$6 / 4 / 94$

$6 / 5 / 94$

$6 / 18 / 94$

$6 / 25 / 94$

$7 / 28 / 94$

$8 / 25 / 94$

$8 / 25 / 94$

$8 / 25 / 94$

$9 / 1 / 94$
Criminal complaint with copies of OFPs and criminal record

Felony-gross misdemeanor first appearance statements of rights

Prosecutor's request of bail in the amount of $\$ 12,000$

Court minutes setting Omnibus hearing, appointing PD, etc.

Judicial determination of probable cause to detain

Order detaining Barber and setting bail at $\$ 12,000$

Notice by prosecutor of evidence and demand for disclosure per rule 9.02

Notice of motion and motion by Barber to dismiss the complaint and suppress

illegally obtained evidence

Contested Omnibus hearing set for 6/5/94

Criminal stalking complaint (felony) with prior OFPs; criminal record

Notice by prosecutor of evidence and demand for disclosure per Rule 9.02 with:

$2 / 29 / 94$ police report and arrest report of $5 / 2 / 94$

Written statements of witnesses

Prior OFPs

Findings of fact and order finding probable cause and lawful entry by police into

Barber's hotel room

Motion for joinder consolidating court files R7-94-842267 and SB420680, i.e., and violation of OFP case with the stalking case

Order consolidating the above files/cases

Seven-page letter from Barber to Debra

Notice of jury trial set for $8 / 25 / 94$

Subpoenas

Petition to enter plea of guilty in a felony case and court minutes ordering PSI

Sentencing minutes (2) for both cases

S9-94-420-849

$5 / 28 / 94 \quad$ Bail request for $\$ 30,000$

6/4/94 Criminal complaint alleging stalking and violation of OFP with copies of OFPs; criminal record

6/4/94 Felony-gross misdemeanor first appearance statement of rights

6/4/94 Court minutes-set Omnibus hearing; bail; appointment of PD

$6 / 5 / 94 \quad$ Order to detain Barber; bail is $\$ 30,000$

6/18/94 Motion to consolidate criminal the two cases by prosecutor

6/24/94 Court minutes-motion to consolidate under advisement; NG plea 
6/25/94 Order consolidating cases

7/15/94 Seven-page letter by Barber to Debra as evidence

$8 / 25 / 94 \quad$ Petition to enter plea of guilty

8/25/94 Court minutes-guilty plea accepted-PSI ordered re stalking

$9 / 1 / 94$

9/4/94 Order appointing a PD

Information from individual practitioners' files

$7 / 16 / 82$

Discharge summary for Barber re chem dependency indicates he was preoccupied with wife and confronted about this

10/17/82 Volunteer jail visitor report of talk with Barber

$1 / 26 / 89$ to DAIP participant service record

$4 / 29 / 90$

$9 / 17 / 88$

$9 / 18 / 88$

$9 / 25 / 88$

$9 / 25 / 88$

$9 / 25 / 88$

$9 / 26 / 88$

$9 / 27 / 88$

$10 / 5 / 88$

$10 / 29 / 88$

$11 / 12 / 88$

$12 / 15 / 88$

$12 / 21 / 88$

$12 / 28 / 88$

$1 / 26 / 89$

$3 / 15 / 89$

$7 / 12 / 92$

$8 / 1 / 92$

Summary of Police report

Order for domestic abuse hearing and ex parte order for protection with Affidavit DAIP contract for participation

Victim's file-includes: victim's report \& release of info

DAIP initial interview and referral form along with history of abuse, etc.

Order finding domestic abuse; restraining order; custody to Debra, etc.

Letter to Judge Hersh from court alcohol counselor

Petition by Debra to allow visitation and joint counseling

Order modifying OFP to allow Barber to move back in with Debra

Conditions of probation

Letter to Barber from Terri Sill of Lutheran Social Services

Letter to Pierce from Lutheran Social Services

Petition by Pierce to review OFP due to non-cooperation by Barber

Copy of $1 / 26 / 89$ order modifying OFP

Letter to Barber from DAIP re missed men's group

Order for domestic abuse hearing and ex parte OFP and affidavit

OFP

$8 / 1 / 92$

$8 / 19 / 92$

DAIP contract for participation

$8 / 20 / 92$ to

$4 / 21 / 93$

$9 / 13 / 92$

$10 / 22 / 92$

$10 / 23 / 92$

DAIP domestic abuse intervention project intake and referral form

DAIP participant service record

$10 / 23 / 92$

$11 / 7 / 92$

$1 / 23 / 93$

$3 / 17 / 92$

$4 / 10 / 93$

$4 / 21 / 93$

Notice to DAIP for Lutheran Social Services that Barber is in counseling Letter to Barber from DAIP suspending him due to violation of OFP

Affidavit of DAIP staff of DAIP re suspension of Barber from DAIP program Order to show cause to Barber to appear based on DAIP staff's affidavit

Order holding Barber in contempt of court

Order allowing Barber and Debra to go to church together

Order pursuant to Barber's request to lift exclusion and no-contact provisions of

OFP. The order allows him lift exclusion from home

DAIP contract for participation

Letter to Barber from DAIP informing him that he completed DAIP program 
2/1/94 Arrest report re shoving incident on 2/1/94

$2 / 12 / 94 \quad$ OFP pursuant to hearing

$2 / 29 / 94$

Incident report re violation of OFP

$3 / 4 / 94$

$3 / 16 / 94$

Incident report re another OFP violation

$3 / 23 / 94$

Incident report re violation of OFP by driving by house

$4 / 30 / 94$ to

Order on OFP continuing matter to $4 / 9 / 94$ \& prohibiting phone contact

$5 / 2 / 94$

$5 / 2 / 94$

Dispatcher's watch report

Arrest report \& witness statements. Barber had loaded gun under bed in hotel room; he was taken to hospital for evaluation

My initial reaction to the whole exercise was one of enormous disappointment. There were hundreds of pages of documents, the recordings of literally dozens of people who in some way had handled the case, and yet there were enormous gaps in information. I had expected to complete the task with most of my questions about what had happened answered. But I had scores of unanswered questions. For example, on $7 / 16 / 82$, when Robert was released from his chemical dependency program, the staff noted that he had been obsessed about his wife throughout the treatment process, which "interfered with his recovery." I can't tell from the record if he was obsessed in a way that posed a danger to her or simply that he wanted to talk about their relationship rather than his own addiction to drugs and alcohol. I can't tell if Debra knew about this obsession. I couldn't tell what his release and his obsession meant to Debra. Did she want him released? Did she have to go to the shelter?

In the second file I put together there were also multiple cases involving an offender who had assaulted two different women over an extended period of time. In one of those cases the prosecutor made a motion to dismiss the charges because the victim, Leslie, had written a letter saying she had lied to the police to get him in trouble. But as I read further I found an almost identical letter written by another woman with whom the offender, Conrad Freisen, had been living 2 years earlier, similarly asking the court to drop the charges because she had lied. I was struck by the finality of missing information. What was missing was permanently missing and if it wasn't in the file, it seemed to have no relevance. For example, in both the Barber and Freisen files, none of the calls to 911 were transcribed or preserved on tape. The motion to dismiss based on Leslie's letter saying she had lied was made 3 months after her call to 911 . I did find the dispatcher's initial complaint report in the police records (not in the court file) and there was a 
comment, "Woman crying . . . says boyfriend tried to choke her unconscious." But by the time the letter came to the prosecutor the tape had been erased and the dispatcher record is available to the prosecutor only upon request. I wonder how helpful Leslie's letter to the court saying she had lied would have been to the defense if the jury had heard the 911 tape and then read the letter from the "lying" victim. 32

I was amazed at how little was ever said about Robert Barber's use of violence in the dozen or more hearings involving his case. I could figure out more about his drinking habits than his hitting habits. I thought I would be able to see what people did as they "worked" on the case but the work of individual practitioners was missing from the record. As I reviewed the file I was critical of all the missed opportunities to get the conviction, but maybe a conviction would not have added to Debra's safety at all. There is no place in the file to look up that kind of information. Apparently she was never asked, "What implications will a trial or a conviction have on your safety?" If she was asked, there was no place in the file to record her answer. I could see what had happened: the violence was erased, and Debra's experiences were not recoverable in this file. But I couldn't see how this erasure had happened.

I realized that text analysis was going to be inadequate because it treated texts as inert objects. I needed to explicate them as actively organizing, interpreting, and screening particulars. I wasn 't going to understand from simply analyzing a file how institutional processes are organized to resolve cases in ways which so frequently fail to protect women. I wasn't as interested in analyzing the text as a entity in itself or reading a particular transcript and completing a textual analysis as I was in following D. E. Smith's instructions to explicate how institutional relations determine the everyday world. These institutional relations are constituted in the local organization of work routines which at the juncture of a woman's experience act to generalize the particular. This makes her accountable to the institutional way of knowing, rather than it accountable to the particulars of her life. It was the relationships of the production of the text, the women's experience, and the safety measures put into place by the court that I needed to understand.

\footnotetext{
${ }^{32}$ According to a Domestic Abuse Information Network (DANN) statistics summary for 1995, 21\% of men arrested in Duluth last year for assaulting a partner had been in court at least once before for battering.
} 
I abandoned the project of analyzing a file and regretted all the time I had spent indexing the six cases. But when I began my observations of case processing, I had a better understanding of what to look for and ask about in my interviews. I began to observe the production of every type of text created in this process. It was during a police ride-along shortly after gathering my files that I began to see very distinct types of texts and distinct roles of texts in the process. I was finally connecting $D$. E. Smith's work to my own. I could see how settings were socially organized courses of action and that no individual practitioner completes such an action. I could start to see how texts on many levels were guiding practitioners as they translated the messy realities of peoples' lived experiences into institutionally recognizable forms which then mandated prescribed courses of action. For the sake of discussing the role of the key texts in a criminal assault case I am delineating them into four categories: administrative texts; regulatory texts; reports, recommendations, and statements; and arguments. ${ }^{33}$

\section{Types of Legal Texts}

Administrative texts include such documents as intake forms, report-writing instructions, court minutes, applications for protection orders, warrant request forms, and applications for a public defender. These texts (a) record and document things that have happened; (b) initiate new proceedings or actions; (c) communicate and link organizational occasions and workers together; and (d) select relevant information by defining the categories of information practitioners are to use when producing a text.

Regulatory texts include documents such as state statutes, instructions to the jury, rules of evidence, case law, department policies, insurance regulations, and city ordinances. These texts set the boundaries of institutionally authorized action and authority. They frame the construction of all of the other texts. They are never attached to the particulars of a case. They pre-date the event that has created a case and require that the case be attached to them rather than allow the particulars of a case to be fully accounted for in the outcome.

\footnotetext{
${ }^{33}$ These delineations are helpful to me in organizing my investigation of work interchanges and my writing; they are not recognized categories in the legal system.
} 
Reports, recommendations, and statements include documents such as police initial investigation reports, psychological evaluations, chemical dependency evaluations, presentence investigations, pretrial release recommendations, affidavits, witness statements, and medical exam records. Most of these texts, with the exception of statements, ${ }^{34}$ are presumed to be objective findings which have been prepared to inform the court on some aspect of the case. They are sometimes evaluative in that they constitute a practitioner's recommendation to the court. While these reports are prepared by individual practitioners, they bear the marks of institutionally authorized ways of thinking about and acting on the case. Here is where we see how practitioners are linked into a larger organization of ruling. Their professional training acts as a framing device as they select particulars from their many observations or pieces of reportable data and link them together in the form of an observation to the court: "Mrs. Peterson is reluctant to move forward with the case, Your Honor," or "Mr. Maki has been under some unusual stresses lately, Your Honor, his mother has just ...." Here the legal system links to the professional discourse and extended relations of ruling. It also links into other institutional ideologies and practices, creating the hegemonic control of the ruling apparatus.

Legal arguments include motions to dismiss, motions to include or exclude something as evidence, objections, jury summations, arguments for sentencing, and defendants' statements for the court record. These texts are both written and oral and are meant to persuade the court to accept a particular version of an account or interpretation of the law. Legal arguments are recognized as efforts to persuade toward a particular bias or viewpoint. They gain currency by linking into established discourses, and like evaluations and reports, they too tap into extended relations of ruling. As I will show, legal arguments frequently hook up with the psychiatric/psychological discourse providing individualized causal explanations of men's violence toward their partners.

\section{Conclusion}

Advocates observe the use of these texts every day but do not observe or necessarily account for

\footnotetext{
${ }^{34} \mathrm{~A}$ statement is assumed to be a product of the truthfulness and objectivity of the person making it, not the result of its process of production. When a woman recants her story to the police her recantation is therefore seen as a reflection of her values, desires, or state of denial and not as a product of institutional practices.
} 
the role they play in making people's lived experiences actionable within the legal system's case processing. It is this active work of texts that gives them their distinctive character and makes them the subject of analysis for advocates. In the next two chapters I discuss texts within their contexts, as part of a sequence of institutionally organized activity. 


\section{CHAPTER SIX}

\section{THE ADMINISTRATIVE AND REGULATORY TEXTS AT WORK}

The active text, by contrast, might be thought of as more like a crystal which bends the light as it passes through. The text itself is to be seen as organizing a course of concerted social action. As an operative part of a social relation it is activated, of course, by the reader but its structuring effect is its own.

That it is activated by the reader means that the activity or operation of the text is dependent upon the reader's interpretive practices. These too are constituents of social relations rather than merely the idiosyncrasies of individuals. They are social in origin and built into social relations. Analysis, therefore, depends upon the analyst-as-member's knowledge of the interpretive practices and schemata relevant to the reading of a particular text. (D. E. Smith, 1990b, p. 121)

The texts I've described in chapter 5 function to move a battered woman's experience into an institutionally recognizable and actionable case. The following chart shows the events that occur in the life of a fictitious woman named Beth. These events share a timeline with the events which constitute the processing of a case. I asked a group of six women whose partners had been arrested for assault to help in its design. They agreed that what Beth is going through during the turbulent months following the arrest of a batterer, would not be atypical. 
FIGURE 6: BETH'S REALITY

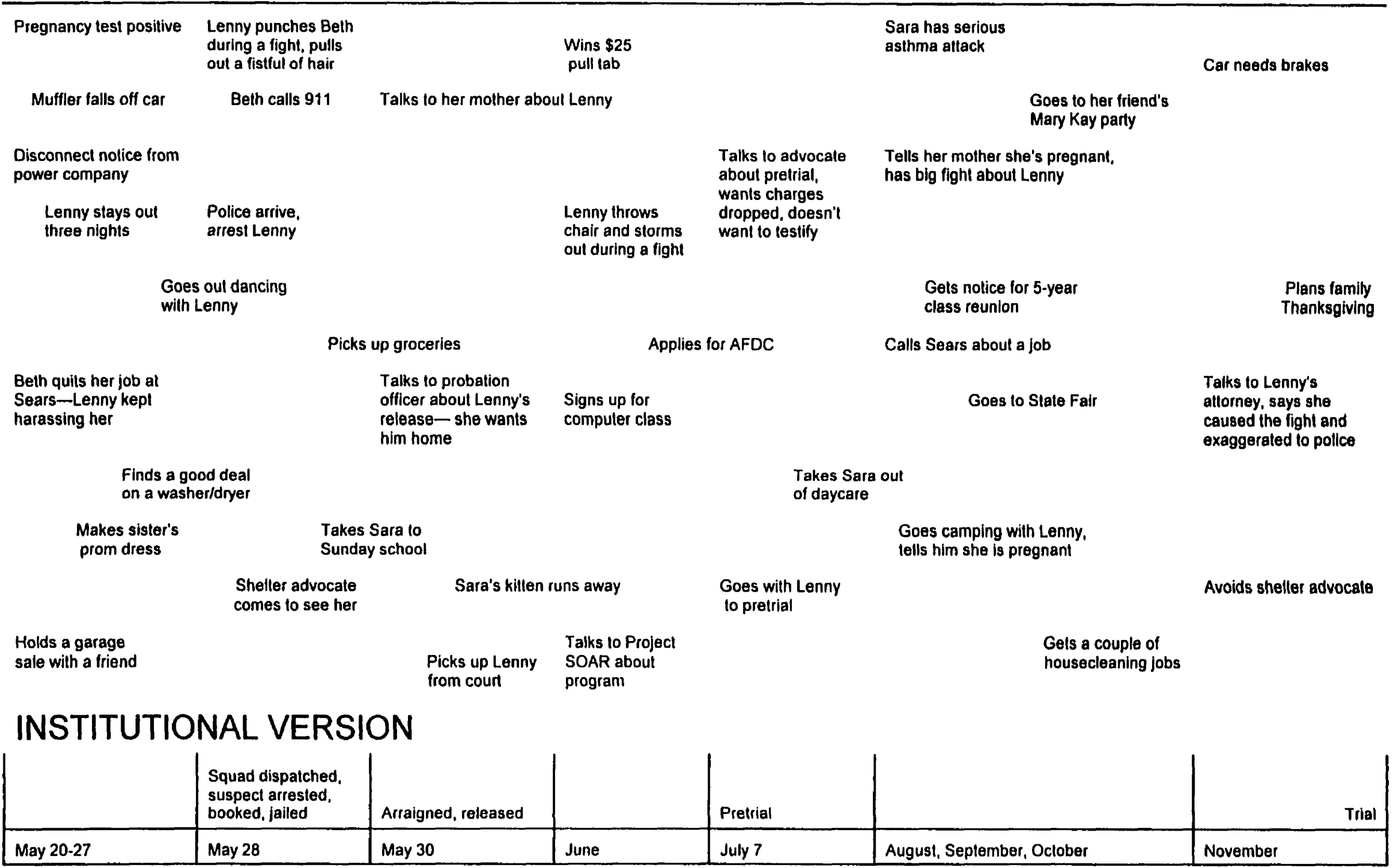


Beth's chart depicts the everyday experiences of a woman that is not as neat and orderly as a criminal court processing chart. The fact that Lenny is being processed as a defendant in a criminal case keeps "popping up" in their lives. It is a process that adds to the stress and tenuous position of their relationship. As the case is processed all of this is absent from the court's treatment of the case. She will be brought into the process as a witness to a crime, a crime against her. As the chart shows, she is far more than a witness.

The Administrative Text at Work

In this chapter I examine the first hour of a case being processed and focus attention on the active work of administrative and regulatory texts in transporting a woman such as Beth from her lived experience into an institutional existence. This case begins with a woman's call to 911. As noted earlier, 911 is the first text utilized in the process. It is a text that connects the reality of the everyday world and the institutional reality, which through its processes and function as a ruling apparatus subsumes the everyday into the institutional. This text is made possible only because of extended relations of ruling that go far beyond citizens' connection to their local police station. ${ }^{35}$ The following is an excerpt from the transcript of the call which activates this text.

Caller: Yeah, I'm calling from 214 East Third Street and I need a squad out here right away.

Dispatcher: What's the problem, ma'am?

Caller: It's my husband, he beat me up.

Dispatcher: Is he there with you right now?

Caller: He's ... getting some of his stuff, he's not suppose to be living here.

Dispatcher: Are you injured?

Caller: No, he punched me in the back but-shit, here he comes.

Dispatcher: I'm dispatching a squad now, ma'am, it's on its way. Can you answer a few questions for me?

Caller [talking to husband]: It's the police, Don, there's a cop on his way right now so don't try anything.

Dispatcher: Ma'am, do you need medical help?

Caller: No, the police are enough.

Dispatcher: Does he have a weapon with him now?

Caller: No ... Get out of here, Don, if you take that stuff it's stealing, the cops are

\footnotetext{
${ }^{35}$ Establishing a countywide 911 system is a major undertaking involving all levels of government. Our county implementation of its 911 system involved issuing new addresses to every household in the county outside the city limits of the seven cities in the county.
} 
coming and you'll get caught for stealing, you bastard.

Dispatcher: Ma'am, can I get your name?

Caller: What?

Dispatcher: Your name.

Caller: Randi, Randi Ward.

Dispatcher: And his name?

Caller: Don, Donald.

Dispatcher: Donald Ward?

Caller: Yeah, yeah.

Dispatcher: Is he leaving?

Caller: I think so, he went out the front door.

Dispatcher: What kind of a car is he driving?

Caller: He doesn't have a car, he's with his friend Tony, who has a blue pickup.

Dispatcher: Which way is he headed?

Caller: I don't know, I can't see them. I'm not so sure they've even left.

Dispatcher: Do you have a protection order?

Caller: Yes, and he's not suppose to be anywhere near here. Oh fuck, now he's coming in the back... I gotta go, get the cops here! [She hangs up.]

This conversation between the woman calling and the dispatcher is directed by an administrative text, the dispatcher's computer screen. It is guided by the questions the dispatcher asks: the questions appear on the computer screen pulled up by the dispatcher when the caller identifies the situation as a domestic assault. One can imagine how many different situations are organized by this screen and treated as similar cases. Appendix $C$ is a copy of the screen that guided this conversation.

The screen is one of three domestic-related screens. It is coded "DOMESP", meaning there is a claim of a physical assault. The other screens are coded in the top right "DOMES," defined as "A verbal domestic quarrel not necessarily blood or married relations . . " or "DOMESW," defined as "A domestic involving weapons or the threat of weapons. This includes guns, knives, clubs ...." These screens direct dispatchers to gather certain information and present the order in which to gather it. The intake dispatcher must assume that the caller will not be free to speak or have time to answer a long list of questions. A dispatcher discusses the priorities:

We get a lot of hangups on these. You see the address come up on where the call is coming from so we don't ask that. We try to first find out what kind of danger the police will be walking into and if we need to get medical there. It goes from there. How to get in, is it an apartment. ... I don't use the screen anymore but you do when you're new, or you use it on a call you're not familiar with." (Interview, October 3, 1995) 
The 911 screen provides an excellent example of the active role of administrative texts in mediating the relationship between the practitioner and the woman who calls for help. This text is doing several things. First, it is standardizing the response of the system regardless of the idiosyncratic work habits of the dispatcher on duty. Any competent dispatcher would have handled the call in a very similar, although not identical, fashion. It screens out institutionally irrelevant information by putting into place a very specific set of instructions for the practitioner on the intake process. It begins by warning the dispatcher of the dangerous nature of these calls. While the dispatcher does not read the warning every time she activates the screen, it is also built into her awareness during trainings and in the questions she is directed to ask. The form requires the dispatcher to assign a level-one priority to the call regardless of the dispatcher's opinion of the level of danger. ${ }^{36}$ It instructs the dispatcher to be cognizant of the key regulatory text this call operationalizes, Minnesota Statute 629.341, authorizing and defining conditions under which officers can make warrantless arrests in domestic-related assaults. The screen is designed to link this organizational occasion to others in the processing of a case; it is an administrative form which assigns a number to the case. As stated earlier, this number is referred to in all future law enforcement entries into the case file. The information recorded by the dispatcher serves as a report to the responding officer and provides information the officer will use in preparing an investigation or arrest report.

The 911 dispatch screen is perhaps the text which most centralizes safety-the safety of the victim, the responding officers, and others. But it focuses only on the moment. In this case the caller hangs up before the dispatcher can complete his questions, but had she stayed on the line his questions would have stopped short of asking about danger beyond the immediate situation. Dispatchers are not directed to ask about past violence or the woman's perception of the offender's dangerousness. The form is not only incident focused, but focused solely on one small part of the intervention process, a problem I also address in chapter 4 . The screen is well designed to link the responding squad to the caller, but it is not well designed to link the needs of the women to those who will take up the case in other organizational settings, such as the

\footnotetext{
${ }^{36}$ The assignment of a priority-one call to domestics is the result of advocacy efforts made in the 1970 s and 1980 s.
} 
advocate, the prosecutor, or the judge who will make a determination on the conditions of releasing the offender.

The woman quickly becomes a data point in the process. The dispatcher directs the conversation, collecting information from her but not engaging in a dialogue. The screen defines the relationship between the two. It is like an interpreter for two people who speak different languages. An administrative text can participate in accounting for the level of danger these cases pose and the safety requirements of the victim. I talked with John, one of the dispatchers, about this.

Ellen: Who put this screen together?

John: I think Nancy and Sherry did that-see it says here 10/08/90, that's when they put together the new system up here.

Ellen: This is the kind of thing we're [DAIP and the shelter] trying to do all the way through the process, put safety in the center of everybody's work. It's not as simple as you would think.

John: Well that's because here we're dealing with the guy before he's been subdued by the system. You know what I mean?

Ellen: I'm not sure.

John: The whole situation is still very emotional when we get it. Everybody is scared of what he might do, or her, too, for that matter. Later when he shows up for court, well, all the screaming and yelling is over and he's just trying to be on his best behavior so as to stay out of trouble. You know, the old suit-and-tie routine.

Ellen: Some pretty bad looking ties, too.

John: I believe you.

Ellen: So do you think that when the man shows up for arraignment that people aren't afraid of him?

John: Not the way we are here. You know people are drinking, it's usually late at night, nobody knows for sure who the guy is we're looking for or who else might be at the scene. You're walking into their territory, guns, knives, it's so unpredictable. The guy has the upper hand if he decides to get crazy on the officers, there could be some people hurt. In the courtroom he's under wraps, you know how I mean. 
John mentions several important features of the legal system's response to these cases. He clearly identifies with the police, even though he works for a different agency. When he talks about danger to the police, he talks about "we." On the other hand, the woman who is most likely to be the person hurt is seen as part of the dangerous "other." She is clearly, like the abuser, an outsider. Later John talks about judges and probation officers as "others" also. He is immediately linked in the intervention process to the police officers responding to the call. John, like most of the practitioners I interviewed, identified as part of a very specific aspect of the overall system. He was connected to the responding police, the jailer, and his co-workers.

John is quite insightful in assessing the context in which practitioners feel the dangerousness of a batterer. When the abuser is removed from the environment in which he is entitled to use violence, the home, his identity changes. He is transformed from an unpredictable and volatile crazy man to the defendant in a domestic assault case. In most organizational settings, the reality of a batterer's violence and the fear and danger it creates for those it is directed toward is detached from the workings of the system. This is a key feature of the institutional setting. It strips the parties from their everyday identities. The police call is the exception: they, like the woman who has called for them, feel the fear.

The dispatcher produces an initial complaint report, known as an ICR. It is linked directly to the police investigation or arrest report; in cases which do not merit a written police report, the ICR stands as the only official document of the call..$^{37}$

Following are two ICRs. The first complaint (Figure 7) resulted in an arrest and therefore a police report was filed. ICRs come through a computer at the police department much like a wire service in a newsroom. Every morning the deputy in charge of the patrol division and the police chief scan the printout, known as the watch report, to get a general idea of the previous

\footnotetext{
${ }^{37}$ Minnesota law requires that officers file a written report if a person claims to have been assaulted by a partner However, many Minnesota law enforcement agencies have a low compliance rate with this regulation, and reports are written only if the officer establishes probable cause that an assault occurred or if the assault results in injury.
} 
day's activities. Detectives investigating felony or gross misdemeanor assaults review it to determine if they should order a transcript of the 911 call. It is not, however, forwarded to the court as the police report is, and it is therefore not accessible to those who are making decisions about the offender's release or later, his sentence. The watch report became available to advocates in Duluth only recently; it is not currently available to advocates in most other cities.

\section{FIGURE 7: INITIAL COMPLAINT REPORT \#1}

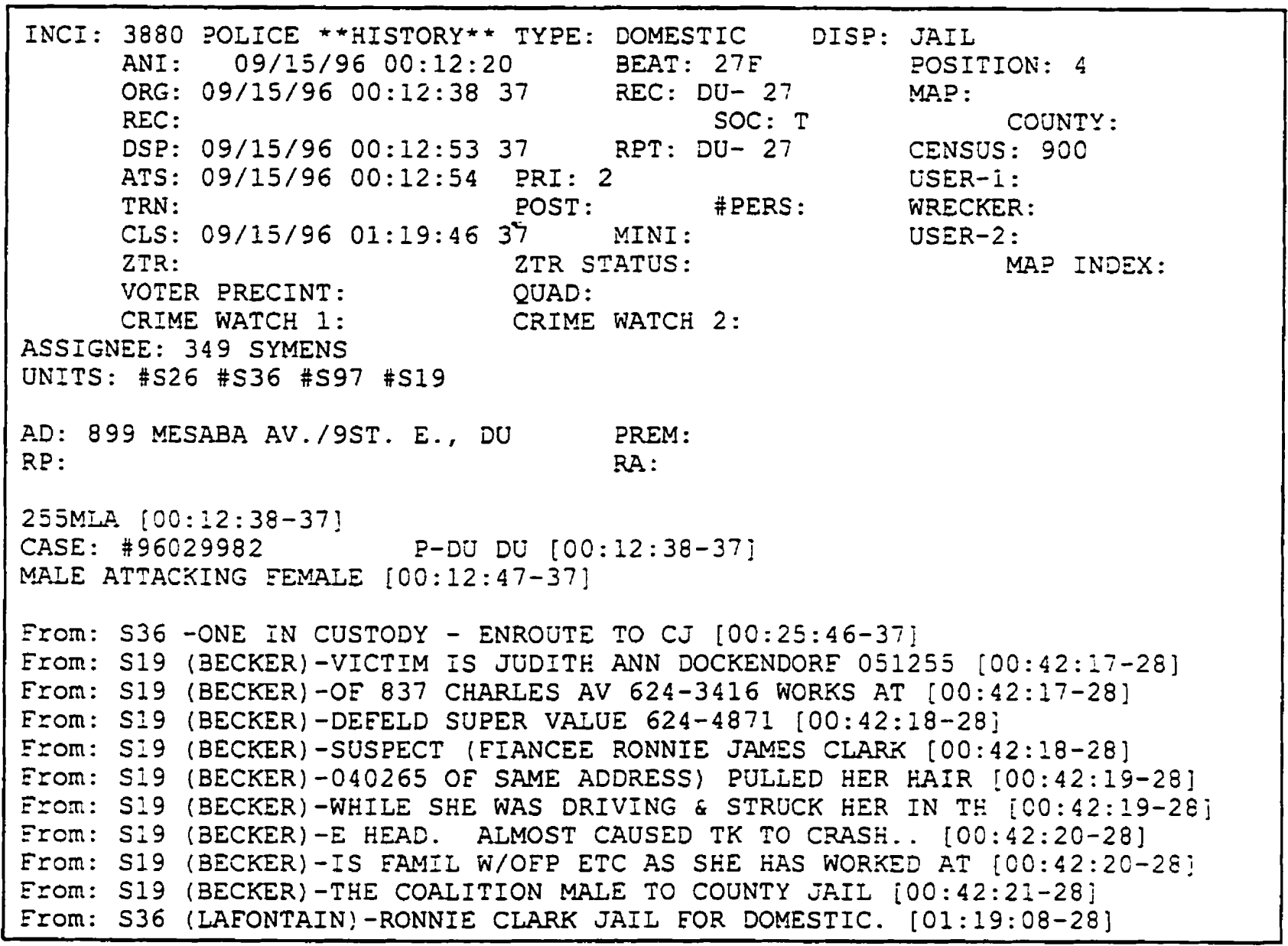

The second ICR (Figure 8) is the only documentation of a call to a home that evening. This report was not forwarded to anyone in the system. 


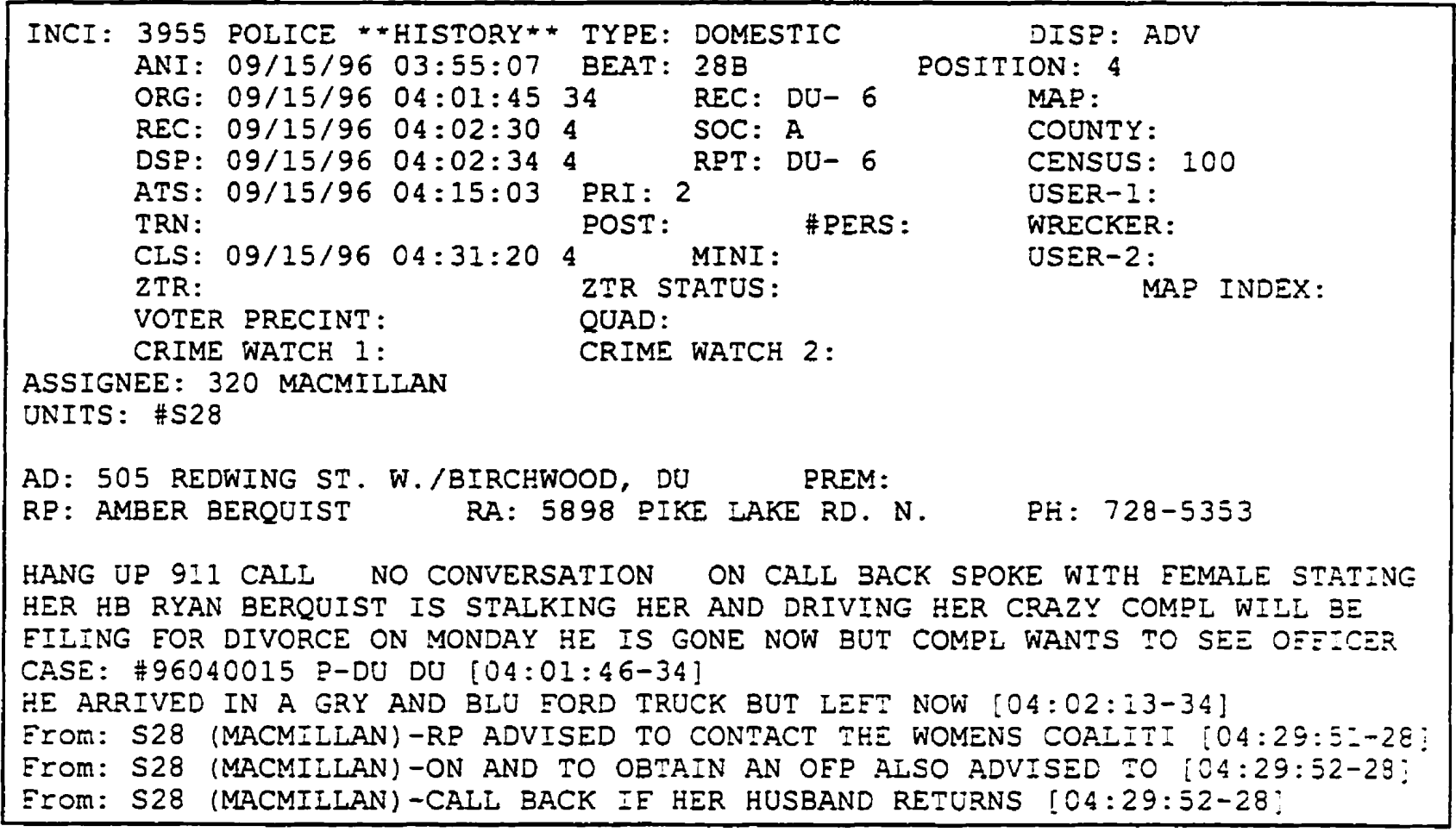

In this case, Amber Berquist is linking into the legal system to say that she is being stalked by her husband. Because Ryan Berquist is not actionable by the police at this point, this call is recorded but goes nowhere. It may in fact be a situation that is quite dangerous, but ICRs are not routinely linked into the advocacy system.

The next document in the process is the responding officer's report (Appendix D). The top half of the police report is laid out to record all of the identifying features of the case, names, addresses, dates, and so forth. The officer identifies the report by assigning it the same number as the dispatcher's initial complaint report. This allows prosecutors and others using these reports later to be sure they have matched the ICR with the right police report. There are frequently several calls to the same residence involving the same people over a 2- or 3-day period. Sometimes there are repeat calls during the same police shift. But as is described in chapter 3 , the legal system deals with incidents separately unless they are considered to be linked to a "continuous course of action," so the ICR number is an important identifier in police

\footnotetext{
${ }^{38}$ For example, in the process of robbing a store a person might violate four or five statutes by committing a gun violation, assault, robbery, and reckless endangerment but be charged with only one crime.
} 
work. The form asks for the date of birth of all parties, which ensures that a person is not misidentified because he or she shares a name with another person known to the police. All of these identifiers are used to process the criminal case but not to link the parties to other mechanisms of support or help, including the women's shelter. Despite the fact that there is an emerging discourse in policing that sanctions the linkages of police to community-based groups, battered women's activists have had to implore police chiefs for the most basic levels of information sharing. There is no little box for the officer to fill in that links this call to shelter or advocacy for battered women. Yet it is at this level of administration that linkages are normalized. ${ }^{39}$

The top half of the police report form, like the dispatcher's screen, links people and texts. It is followed by the narrative. Administrative texts are present at every organizational occasion. They are a primary mechanism by which institutional objectives are inserted into the management of a case. They are created extralocally; individual experience is fitted into them. At each organizational occasion there is an opportunity to incorporate safety measures for women into the administrative text. I will repeatedly make the point that the objective of safety is not structured into the system, as is the objective of determining guilt or innocence. To alter the system we need not replace the objective of processing the case as a crime but add a parallel, equal objective: to ensure victim safety, so that even when the criminal case drops out, the objective of securing victim safety remains institutionally actionable.

\section{The Regulatory Text at Work}

As police begin to gather information for their report we are about 3 minutes into a case that will likely take 3 months to resolve. While the officers are approaching the scene, the dispatcher contacts the county jail, where copies of all active locally issued protection orders are on file. The dispatcher checks on past calls to the home. These two administrative routines provide officers with a partial institutional history of the parties involved. Institutions coordinate the activities of a diverse group of agencies and individuals which make up the state's apparatus of ruling. In the span of 4 or 5 minutes, a county agency, the dispatch center, has linked with the

\footnotetext{
${ }^{39}$ Duluth Police Department gives advocacy groups access to ICRs and arrest and investigation reports, but it is in a small minority of departments which exercise this option.
} 
city police and the county sheriff's department to coordinate the beginnings of an institutional response to a citizen's call for intervention. Much of that coordinating work is being done by the text.

The jailer confirms that Randi does have an order for protection against Donald and reads the specifics of the court order to the dispatcher, who electronically notifies the responding officers.

Violation of an order that excludes a party from a residence or restricts his access or contact with the victim is a misdemeanor in Minnesota, and state law requires an officer to arrest such an offender. Here the regulatory text of the state law and department policy come into play as officers encounter the parties. It is the invisible text in the case. In all phases of case processing the regulatory text is represented in how practitioners frame their reports, what observables they select for recording, and how they make sense of those observables, but the regulation itself is not present in any case file or record.

Randi Ward's protection order excludes Donald Ward from "being at or near the residence of the petitioner," and prohibits him "from establishing any contact in person, by phone or by third party with the petitioner." This court order is a representation of Minnesota Statute 518.B.01, authorizing the court to restrain persons who have been found to commit acts of domestic abuse from being at or near the residence of the petitioner (in this case, restricting Donald Ward from being at or near the house of Randi Ward). This statute requires that a person must know of the order to be in violation of its terms. The police report on the call states,

Randi Ward provided me with her copy of the OFP, and it indeed stated that it prohibited Donald Ward, DOB 5/6/68, from being at or near her residence and from not having contact with her through a third party. I asked Donald Ward if he was served with the OFP. He stated that he had been. I then asked him how long he had been at this address today. He stated that he had been here for approximately 45 minutes. I asked him if he knew this was the residence of Randi Ward. He stated yes, that this was his house too, and that he had some things ... that she was suppose to give him but she didn't so he was just trying to get some of his personal belongings. I asked him if he knew it was a violation for the OFP that he had been served. He at first stated that he did not, but then stated yes he did. Having this information I concluded that Ward had knowingly violated the OFP, and I had probable cause to make an arrest.

I then informed Ward that he was under arrest. I applied, gapped, and double-locked my 
handcuffs on his wrists and completed a custodial search. A short while later, I transported Ward to the St. Louis County Jail where he was lodged on a misdemeanor charge of a violation of a protection order.

The officer's report is organized by state statute and the elements of proof needed to establish guilt later at a trial. Every statement ("I asked Donald Ward if he was served with the OFP") provides for a coherent account of an investigation that leads to a certain institutionally authorized course of action, in this case arrest. Elements of proof are established by the state legislature, and rules of court defining what can be admitted into a trial as evidence are established by the state supreme court. ${ }^{40}$ The law in Minnesota evidentiary rules translate into questions for the officer: "Did Donald Ward knowingly and willingly violate the court order?" Regulatory texts are created through the political process and are always extralocal. They are created separately from the particulars of the situations they are authorized to govern. The local is fitted into the abstracted system of institutional modes of ruling. In this case, officers arrested Donald Ward for violating a protection order. He was charged with a misdemeanor and eventually sentenced to 30 days in jail, but the time was suspended on the condition that he would complete a 27-week men's nonviolence class. Had Donald committed this crime several years earlier or in another state, ${ }^{+1}$ he might have been given the option of leaving the residence rather than facing arrest. ${ }^{42}$ Donald lives in a city in which the police department has enacted a policy requiring officers to arrest in domestic violence cases if certain conditions exist (see Figure 9).

\footnotetext{
${ }^{40}$ Minnesota Rules of Court are published annually and provide updates on trial and appellate rules, professional rules, and federal rules of court.

${ }^{41} \mathrm{Half}$ of the states have passed legislation making violation of a protection order a mandated arrest situation (National Council of Juvenile and Family Court Judges, 1996), although I would guess that fewer than $20 \%$ of police departments require officers to make such an arrest.

${ }^{42}$ Mandatory arrest is opposed by many activists because it increases the number of poor, working class, and immigrant men coming into a classist and racist system. Women are reluctant to subject their abusers to the adversarial court process, and the racism and classism increase their fears of using the system.
} 


\section{DULUTH POLICE DEPARTMENT POLICY}

SUBJECT: DOMESTIC VIOLENCE

\section{PROCEDURE}

\section{A. Assault With Injury}

A person SHALL be arrested and taken into custody when an officer has probably cause to believe that a person:

- has assaulted another person and there is visible signs of injury or physical impairment; or

- the victim was threatened with a dangerous weapon.

For an arrest to occur...

B. Assault Without Visible Injury or Physical Impairment

A person MAY be arrested and taken into custody when an officer has probable cause to believe that person:

- has assaulted another person without injury; OR

- has placed the victim in fear of immediate bodily harm.

For an arrest to occur...

C. Mutual Combat/Self-Defense

When evidence of mutual combat is present, the sination does not necessarily dictate the arrest of both parties. Officers must determine...

Donald also lives in a state in which officers are required by statute to arrest if a person knowingly violates a protection order that restrains a person from having contact with the petitioner (see Figure 10). 


\section{DULUTH POLICE DEPARTMENT POLICY}

SUBJECT: ORDERS FOR PROTECTION

\section{PROCEDURE}

\section{A. Mandatory Arrest}

Minnesota Statute 518B.01, Subd. 14(b) REQUIRES an officer to arrest and take into custody a person the officer has probable cause to believe has violated the sections of an Order for Protection by:

- restraining the person (from committing further acts of domestic abuse, as defined in G.0. 230.01); or

- excluding the person from the residence or the petitioner's place of employment.

An arrest is required even if the violation did not take place in the officer's presence. There is no time constraint on arrests.

State stante requires an arrest regardless of whether or not the person was admitted into the residence. Minnesota Statute 518B.01, subd. 14(g) states that it is not a violation for the petitioner to admit the other person into the residence; per Minnesota Statute 518B.01, Subd. 6(d), such action does not void the Order.

B. OFP Verification

\section{PRIOR TO MAKING THE ARREST THE OFFICER MUST VERIFY:}

- the existence of the Order for Protection; and

- that the offender knew the Order for Protection existed. (This does not apply in "Temporary Orders")

C. Investigations

Violations of an OFP which do not involve a mandatory arrest are documented in a report. Officers should weigh...

This policy was the result of local activists, including many women who had been battered, working with police administrators to strengthen the civil protection order by ensuring its full enforcement through criminal procedures. It was made possible by the work of activists who worked at the state level to expand police powers of arrests in these cases. Prior to the work of the movement, police officers could not arrest on a misdemeanor assault unless they witnessed the offense. A women could make a citizen's arrest by requesting the officer in the presence of the abuser to arrest him. This rarely occurred. Officers almost never arrested for violation of a civil protection order unless there was another assault. In 1983 activists successfully lobbied for an amendment to the Domestic Abuse Act mandating officers to arrest for violations of civil protection orders (see Figure 11). 


\section{DOMESTIC ABUSE ACT}

Minnesota Statute 518.B.01

Subd. 14. Violation of an order for protection.

(b) A peace officer shall arrest without a warrant and take into custody a person whom the peace officer has probable cause to believe has violated an order granted pursuant to this section restraining the person or excluding the person from the residence or the petitioner's place of employment, even if the violation of the order did not take place in the presence of the peace officer, if the existence of the order can be verified by the officer. The person shall be held in custody for at least 36 hours, excluding the day of arrest, Sundays, and holidays, unless the person is released earlier by a judge or judicial officer. A peace officer acting in good faith and exercising due care in making an arrest pursuant to this paragraph is immune from civil liability that might result from the officer's actions.

The battered women's movement has been most effective in changing regulatory texts and has in many states, including Minnesota, become quite adept at using the legislative political process. But legislation which mandates certain courses of action and agency policies which prohibit practitioner discretion are always problematic, because they lump together disparate events, decreeing dissimilar situations to be similar. This has been the dilemma for activists advocating for policy and legislative reforms. In one sense activists have tried to factor into the law language which accounts for the special nature of these types of assaults and acts of violence, but we have not been able to fully escape the problems inherent in the generalizing character of regulatory texts and processes. Any process which requires that the particulars are fitted into the general compromises attention to the lived experience. A police officer explains the dilemma from his perspective:

I have no problem arresting a man who violates a protection order by going back over to the house and harassing a lady. If he's driving around, watching her and keeping her in that fear I'll gladly throw him jail. But the law also makes me throw guys, and some women, in jail that seems unfair. I had a guy who was coming home every Saturday and mowing the lawn, working around the house because they were trying to sell the place. Well, one of these days his new girlfriend shows up to bring him some keys or something and his ex finds out he's been shacking up with this gal, and boom, she calls 911 and reports him for violating his protection order. Was she in so much danger that I had to lock that guy up? No, but the law takes away my discretion to make that decision. (Interview, July 17, 1995) 
Of course many advocates would argue that police have so misused their discretion that mandating certain courses of action has been a necessary step. Others would argue that the man this officer arrested should never have been at the house in the first place and would dismiss the officer's sympathy for him. Neither of these arguments is the point here. The officer is correct in observing that laws cannot account for the particulars of local events. Local events are forced into policy or abstracted systems of governing, and safety is often compromised in that process. For example, assault laws in all 50 states categorize assaults into two or more levels of seriousness and thereby activate different levels of punishment for those convicted of it. Minnesota law defines 11 levels of assault, ranging from first-degree felony to fifth-degree misdemeanor.

\section{C.211 FIRST DEGREE FELONY ASSAULT}

Whoever assaults another and inflicts great bodily harm may be sentenced to imprisonment for not more than 20 years as or to payment of a fine of not more than $\$ 30,000$, or both.

\subsection{FIFTH DEGREE MISDEMEANOR ASSAULT}

Whoever does any of the following commits an assault and is guilty of a misdemeanor:

(1) commits an act with intent to cause fear in another of immediate bodily harm or death; or

(2) intentionally inflicts or attempts to inflict bodily harm upon another.

In Minnesota as in most states, the level of seriousness correlates to the bodily harm done in the assault or the potential harm based on the use of a weapon. Bodily harm is categorized accordingly to broken bones or permanent physical injury, so that a single slap to the side of the head that results in damage to the eardrum is a felony, whereas multiple blows to the body that result in deep bruising, cuts, and scrapes constitute a misdemeanor. Following is an excerpt from a police report documenting the arrest of a woman who had been physically and sexually abused by her partner for years.

I asked Diane Winterstein to tell me what occurred, she said her husband Phillip had come home after drinking at the $Y \& R$ bar and was becoming very belligerent. She said he told her that people were "reporting on her." I asked what he might have meant by that and she said that he acts like everybody is his personal watch guard over her and that he makes up affairs she was supposed to have and then says his reporters saw her with 
someone. She went on to say that Phillip started pushing furniture around. I noted that a chair was pushed over in the dining room. She then went into the kitchen and got out a steak knife and threatened to "poke his eyes out" if he didn't leave the house immediately. I asked her if she was in fear of grave bodily harm at this point and she said no, she thought he was going to leave. Then according to Diane he started to call her names like "whore" and "bitch" and "cunt," at which point she lunged at him and "poked him in the right hand with the knife." She said when he saw the blood he started to cry and she called him a "big baby," at which point she says, "he grabbed me by my hair began pulling me toward the bathroom and kicking me." She stated that he kicked her three or four times in the legs and right hip area. I asked her if there were any bruises. She showed me the area of her right hip which was red and swollen and beginning to bruise. I asked her if he did anything else to assault her and she stated that he threw her up against the wall and told her that this time she had gone too far. I asked her if she had been violent to him in the past and she said that she often threatens him to get him to leave her alone .... She said that he slapped her across the face twice and then spit in her face. .. . I conferred briefly with Officer Dickie and a decision was made to arrest both parties. I informed Diane that I was placing her under arrest for 2 nd degree assault and took her into custody without incident. ... Officer Dickie placed Mr. Winterstein under arrest for 5th degree assault (see Officer Dickie's report for more details). . . . Officer O'Keefe took pictures of both parties' injuries. Both refused medical treatment. I placed a kitchen knife shown to me by Diane Winterstein as the one she used to stab her husband into evidence.

In this case Diane Winterstein faced a prison sentence of 10 years. She was charged with second-degree assault for "stabbing her husband with a deadly weapon." Because it was her first offense, she spent only 11 days in jail and was ordered to classes for offenders. Phillip Winterstein pled guilty to a misdemeanor assault and was sentenced to 1 year probation. He served 2 days in jail, and was ordered to attend 27 weeks of DAIP men's educational groups. It is the generalizing character of the law that impedes practitioners from intervening in this case in a way that will protect Diane from future assaults. In fact it is quite possible that she has actually been made more vulnerable to her abuser by this state intervention than had the police never arrived at her door. Yet each practitioner in this case did their job.

In most cases the battered women's movement has used the legislative process to structure safety into the ways that police and the courts handle domestic assault cases. We have promoted laws which shift the onus of placing controls on abusers from the victim to the community. For example, in every state advocacy groups have successfully lobbied to expand police authority to arrest, eliminating the need to ask the victim if she will make the charge. We have in many districts secured agreements with prosecutors to discontinue the almost universal practice of 
dropping charges at the request of the victim. ${ }^{43}$ We have expanded the kinds of testimony and evidence that can be used by the state in these cases to prove assault, making the victim testimony less crucial for obtaining a conviction. We have also lobbied to expand the power of police and courts to take protective action through using civil protection orders, notifying victims when offenders are released from incarceration, establishing longer periods of probation for domestic assault-related offenders, recognizing protection orders across state lines, and making stalking behavior a felony offense.

While the legislative agenda of the battered women's movement has definitely been safety oriented, we have not been able to fully escape the problems with generalizing texts as Diane Winterstein's arrest shows.

\section{Conclusion}

The battered women's movement has argued for consistent enforcement of the law in domestic abuse cases and has lobbied for a broad range of changes in legislation and policy in every aspect of criminal law as it relates to these cases. Yet, it continues to struggle with the inherent problems that generalizing texts pose when applied to the wide range of circumstances they are designed to encompass. Policies and laws must be designed with an eye toward allowing for the particulars of a case, especially as they might influence a woman's safety.

${ }^{\sqrt{3}}$ This position is controversial in the movement. We know on one hand that if a women's request to drop charges automatically results in a dismissal, then most batterers can and will exact such a request from their victims. We also know that prosecution of an individual batterer is frequently not helpful to the individual woman he has beaten. The battered women's movement has argued that women should be allowed to retain choices in the processing of a case. 


\section{CHAPTER SEVEN \\ LEGAL ARGUMENTS AND EXTENDED RELATIONS OF RULING}

A small percentage of domestic violence-related cases go to trial. The majority of these are settled in pretrial or omnibus hearings with a negotiated arrangement between the prosecutor and the defense attorney. Most legal arguments do not occur in the elaborate courtroom scenes witnessed in the O.J. Simpson trial but in settings in which dozens of cases are disposed of in a matter of hours. Legal arguments are made at several points in a case. In this chapter I use arguments presented at sentencing hearings in order to show one way in which the legal institution is linked through discursive practices to extended relations of ruling, particularly the "psy" professions. The adversarial legal system culminates in a storytelling contest (legal arguments) in which one story wins and the other story loses.

Legal arguments always involve attempts to put a certain "spin" on a set of "facts." The "facts" of the case may come into question as much as the interpretation or the version that one side or other in the adversarial system wants the court to accept. I talked with several judges about the impact of the adversarial system on women's safety. Their comments attest to the rather brutal character of the system.

The adversarial system mocks the role of ethics in the process. A lawyer is taught to zealously represent his client even if his client is an axe murderer. It's the lawyer's job to cast aspersions on any piece of evidence that indicates his client did it, whatever it is. The judge or the jury is the fact finder and as such they are not allowed to ask questions. The facts are presented by the two adversaries who seek to disparage their opponent. The defense attorney enshrines his client. It is actually the job of a lawyer to construct a lie and then convince people of its truth. ${ }^{44}$ (Interview, October 11, 1996)

Most battered women want to do something so that they don't get hurt again. If she goes the criminal route she may risk the relationship, which may not be what she wants... Even if she does want to get out of the relationship ... she doesn't want to do it in a hostile way. The civil route is much more what she is looking for but it's tainted with the

\footnotetext{
${ }^{44}$ At the time of the interview this judge was reading the book Guilty: The Collapse of Criminal Justice by Judge Harold J. Rothway (Random House, 1996) and I believe was paraphrasing the author.
} 
adversarial notion of truth finding. Its advantage is that there is no punishment attached to winning, but then again, it's not as strong an intervention as a conviction. (Interview, October 12, 1995)

The criminal justice process is a glorification of the dispute, it's not a search for the truth. (Interview, September 11, 1996)

The adversarial system calls for a representation of the parties to the case that reflects preformulated categories of abuser and victim. It does not call for a representation of the complexities of a specific woman's life. These pre-figured subjects are created in a professional discourse which links into the legal system through extended relations of ruling, leaves women's experiences unaccounted for, and greatly compromises the likelihood of practitioners engaging in practices protective of women.

The activities that constitute the production of a story (or "spin") are often invisible, as manufactured accounts enter the courtroom represented as factual or as the authentic voice of one of the parties involved.

To illustrate how accounts are manufactured in an adversarial system, I want to use the transcript of a taped discussion I had with a woman in 1991 about a charge against her for filing a false police report. Karen had come to my office one day with a stack of papers, asking for assistance to get the charges against her dismissed. We talked for a while. I read the police report regarding the night she was assaulted, I read her statement to the court saying she had lied to the officers, I read the memo by the county attorney asking to have her charged, and finally I read the subpoena to appear in court on the charge of filing a false police report. She also gave me two protection order petitions she had made to the court against her boyfriend, which I glanced over quickly. ${ }^{45}$ I asked her if I could interview her on tape and said that I might use the transcript when talking with the city attorney. During part of this conversation she read directly from her police statement.

\footnotetext{
${ }^{2 s}$ A protection order petition contains an affidavit by the petitioner, in this case Karen, describing incidents of abuse that cause her to need court protection.
} 
Karen: Keith called me from this bar he was at and said he was coming home. He was in a bad frame of mind. Then a little while later, he called me back. He had gotten in a fight with a Black guy, and Keith is very prejudiced against Blacks. He said this guy had jumped him. Anyway, he got hit. We've had lots of fights over his attitude, because he wants me to stop seeing my Black friends, which I won't do. So, he was yelling on the phone about niggers, and how I loved niggers. He was with his ex-girlfriend and said they were both coming over. I told him not to bring her over, but he hung up on me. I didn't want him to come over like that 'cause he is not too predictable. So I jammed the door with a bunch of knives to keep him from being able to get in.

I called this neighbor in my building and told him that I might need help. He suggested I call the police, but I didn't really want to get them involved. I called the dispatcher and asked if a car could just drive around and check on things, but they said if they sent a car out, they'd have to come to the door and check on things, so I said OK.

Keith showed up almost right after I called, and he started on me about how I want niggers and a bunch of stuff. I argued with him, and he started shoving me around. I was getting tired of being shoved, so I threw my glass of water in his face. Then I threw the glass at him, and it hit him in the chest. I turned and ran out of the door, but he caught me and dragged me back in. He was looking for the glass. He found it and picked up a piece of the glass from the floor and told me to apologize for throwing it. I didn't, so he started choking me and asking how I thought it felt to be hit with the glass. I said it would probably hurt. Then he held the piece of glass up to my throat, so I apologized by telling him that I was sorry for stooping to his level. That's when the police showed up.

Ellen: Is this the story you told the police?

Karen: Yeah, except I told them that Keith broke the glass, and I didn't tell them that I threw the glass at him. But I called the desk sergeant up right away and told him that I left it out. [The police records indicate that she called 27 minutes after the arrest occurred.]

Ellen: So, is that why you were charged with filing a false report?

Karen: No, Keith took me and his ex-girlfriend down to his attomey and told us we had to change our stories or he'd go to prison. He was already on probation, and this was a gross misdemeanor or maybe a felony. It was on the day he was supposed to go to court.

Ellen: Was Keith in the room when you talked to his attorney?

Karen: No, he was standing outside the door, but he was going to read it [her statement] when I was done, so he could have just as well been standing there. 
Ellen: Did his attorney ask you if Keith was coercing you or making you do this?

Karen: No, he just asked me what happened and I started to tell him, and then he would say things like, "If that's what you say, he'll be convicted," but I can't say he actually told me what words to use.

Ellen: Did you tell the attorney you weren't afraid when Keith held the glass up to your throat?

Karen: That's what I was there for. That was what he was going to go to jail for. So that's what I had to change.

Ellen: Were you afraid?

Karen: Have you ever met Keith?

Ellen: No, but I know quite a bit about him.

Karen: Well, if you know a lot about him, then you know I was afraid ... he's a very dangerous person. ${ }^{46}$

Here we see the intersection of a man's willingness to use violence, his attorney's willingness to stretch the boundaries of ethical behavior, the adversarial nature of U.S. criminal law, and an overly specialized work force producing an account that endangers a woman who would likely have been safer had the criminal court not intervened in any way in her life. In this case, the activities that produced the account are not visible to the courtroom observer. Even when the work of creating the "spin" is observed directly, the hegemony of certain of certain ways of thinking makes the ideological practices within the legal system difficult to discern. I want to use several sentencing hearings to illustrate this point.

The first is typical of dozens of sentences in domestic violence cases. It illustrates how the case involving the assault of a woman culminates in a disposition by the court. Ordinarily in these hearings there is the introduction of the case by either the prosecutor or the defense attorney; a word or two about the offender by the defense attorney; a report by the probation officer on the presentence investigation; a discussion about the numbers of days that the defendant has already spent in jail; a summary of the agreement between the prosecutor and the defense attorney

\footnotetext{
${ }^{46}$ This transcript appeared in slightly different form in a previously published article (Pence \& Ritmeester, 1992).
} 
regarding jail time yet to be served; some mention of conditions of probation; a reference to alcohol or alcohol treatment; and a short statement by the defendant or a comment regarding victim input. The judge says a few words, then imposes a sentence. Following are excerpts from a typical sentencing hearing. The full hearing transcript is found in Appendix E.

The Court: Mr. Barns?. . We'll go on record in the matter of State of Minnesota versus Benjamin George Barns. . . . The Court in this matrez has received a Pre-Sentence Report from Mr. Pegg dated February 1, 2995 .

The presentence investigation in this case is presented in written form to the court. This is a felony assault; a misdemeanor assault presentence investigation is given orally. The presentence investigation report in this case had no description of the history of violence or the statements from the victim about the violence. It did lift language from the police report describing the assault in the incident.

Next, both the prosecutor, Mr. Torez, and the defense attorney, Mr. Holmes, are given an opportunity to dispute the recommendation of the probation officer. In this case neither does.

(Excerpts from Appendix E)

[Prosecutor]: Your Honor, we also accept the repcrt as factuaily consistent with our information and the Guidelines worksheet as accirate. Witi. regard to the recommendation, we concur with the recommendation of Mr. Segg i: the report. . . .

[Defense Attorney]: Well, I have to agree that the recommenciations I think are fair. They are consistent with the plea agreement in the case. I'n going to ask the Court to follow those recommendations. That's ali that I have.

The probation officer's report goes uncontested. It follows a routine that everyone can agree to. The presentence investigation looks at past convictions, past compliance with court orders and instructions, the general citizenship qualities of the offender (e.g., does he work, does he have debts, the length of time he has lived in Duluth). There is no attempt here to understand Mr. Barns as a batterer, only as a candidate for probation or as a potential flight risk.

It is Mr. Barns himself who offers the explanation for his crime.

(Excerpts from Appendix E)

The Court: Mr. Barns, anything that you wish to say?

The Defendant: Yes, I haven't drank [sic]. I've been-since the incident, since I've been out of jail I've been going to AA, and-and 
spirituality, I-he's kind of the man I see. It's a Native American, Ojibwa ways, spirituality, I've been seeing him at least once a week and tzying to get that back together. I've been doing pretty good. Carrie, the victim, would be here today, but her grandfather just passed away. That's about it, I guess.

The Court: The Court then at this time will formally accept Defendant's plea of Guilty as well as his written Petition to plead such that the Defendant now stands before the Court adjudged and adjudicated Guilty of Assault in the Eifth Degree, a felony. As for a sentence, it is the jucigment of the law and the sentence of this Court that the Defendant be committed...

The court sentences Mr. Barns to a stayed (he won't actually be incarcerated) 1-year jail term (this was his third domestic abuse-related conviction). The prosecutor then brings up another matter. Mr. Barns had attempted to coerce the victim into refusing to testify against him and was charged with obstructing legal process. He had pled guilty to this charge as well and the prosecutor wants a conviction entered into the record.

\section{(Excerpt from Appendix E)}

[Prosecutor]: Your Honor, just that I'd ask for, also the Cours to impose the sentence on the Count II Obstructing Legal Process as recomenced there, that being a 90-day sentence stayed for one year of probation concurrent with the other sentence.

The Court: Mr. Holmes, you have any comment on that matcer? Honor.

[Defense Attorney]: I think that was part of the piea agreenert, youz

The Court: On the charge of Obstructing Legai Process, the Colizt wi:impose a sentence of 90 days in the County Jaii; execution of that sentence stayed in favor of one year of probation, that year to be served concurrent with the first year of Defendant's probation on the felory and on the same terms and conditions.

[Defense Attorney]: Thank you, Your Honor.

[Prosecutor]: Thank you, Your Honor

The Court: Thank you, gentlemen.

(Proceedings concluded at 9:12 a.m.)

The court essentially throws another conviction in with the felony assault and sentences $\mathrm{Mr}$. Barns to the same non-jail time he has received for beating the victim. The record show two convictions, two sentences, two dispositions, the excuse that "the drinking made me do it," and no mention of the violence or the injuries and threats to the victim, whose name is mentioned only in passing.

In this felony case there is no discussion about the violence or the safety needs of this victim. The presentence investigation report to the court is based on the offender's criminal record, not how this incident fits into an overall pattern of coercion or intimidation. The written record 
contains no documentation of the offender's use of violence or intimidation of this victim over several years, only a very general summary of the assault. During the hearing neither the defendant nor the court mention the violence, just the alcohol. As in over 70 percent of the cases I observed, alcohol is involved and is either discussed as the cause of the assault or becomes the focus of sentencing. During this hearing reference is made to two regulating texts, the sentencing guidelines and the fine schedule. The probation officer has complied with the procedures and guidelines set forth in these texts.

The next sentencing hearing involves the murder of a woman whose husband had "caught" her in bed with another man. The case occurred in Baltimore in 1994, at the same time that I was beginning my observations of sentencing hearings. I read about the case on the Internet and ordered the transcript. When I read it, I could immediately see that all of the talk in this case provided the subtext for the cases I had been observing. The full transcript is found in Appendix F.

In this case the "facts" are not in dispute. The man with whom Sandra Peacock was having a sexual relationship provided detail testimony at the trial about the events that led up to Kenneth Peacock's discovery of Sandra and him in bed. Kenneth then described what happened during the approximately 2 hours he was alone with Sandra. He testified that they had sat on the couch talking, that they had had several drinks, and that he had then shot her. Neither the state nor the defense challenged his version of the night's events.

We hear the voices of four people at this hearing: the prosecutor, who represents the State of Maryland; the judge, who represents the court; the defense attorney and the defendant, who constitute the defense; and the victim's mother, who represents the victim. Because the victim has been killed, her mother is asked to provide information to the court through a victim impact statement. The other voice, one not represented by a particular person in this hearing, is the voice of the state legislative body. The state legislature enacts the criminal code (a regulating text) and sets sentencing guidelines (a second regulating text) which the judge must follow. Any judge who deviates from them must write a memorandum explaining the reason for doing so. 
In this case the defendant was charged with first-degree murder for shooting and killing his wife. A plea agreement was made, and he pled guilty to manslaughter, which under Maryland law means that there was not the requisite intent to kill. (Thus accidental deaths caused by the negligence of the accused are considered manslaughter.) The third regulating text involved here is the "defendant's score" which is a scale used by the State of Maryland to rate the offender before the court. This score is determined during a presentence investigation by asking background questions about the defendant and looking at information on past convictions. In this case the defendant has no previous convictions. His score is therefore quite low, considering the offense.

The defense attorney had agreed to a negotiated plea of manslaughter, which under the sentencing guidelines means a sentence involving 3 years of incarceration.

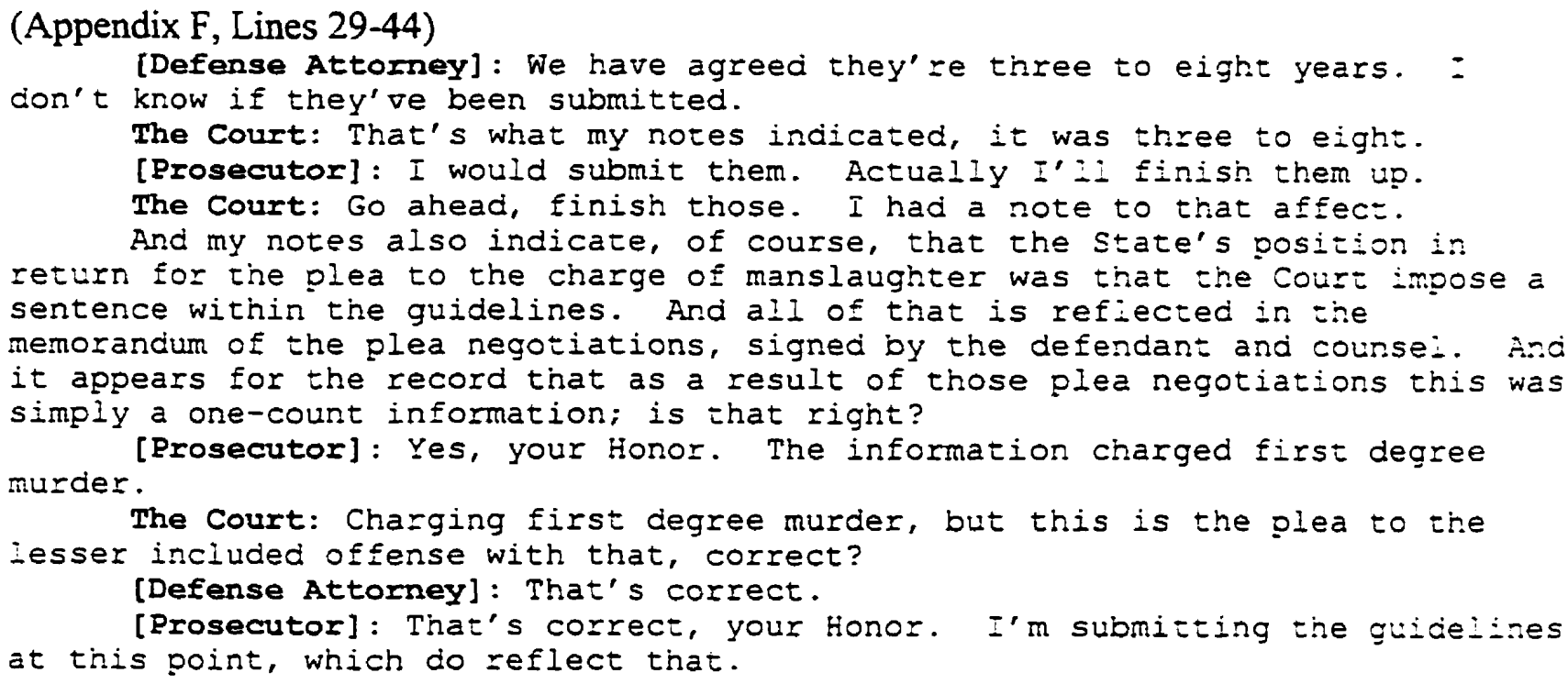

The remaining part of the hearing is taken up by the defense counsel arguing that the court could in fact decide that incarceration would not be appropriate; the prosecutor, speaking on behalf of the state and the victim, arguing that incarceration is appropriate; the defendant asking that no jail time be imposed; and the judge explaining his decision to place the defendant in a residential work-release program (in which the defendant will be restricted only at night) for 18 months, followed by 1 year probation. Each of these legal arguments centers on the presentation of a version of Sandra's death. 


\section{Versions of Sandra's Death}

Each of the parties, the state, the court, the defense, and victim, as represented by her mother, offers a version of Sandra's death. The sentencing hearing becomes an avenue for all interested parties to create a version of the facts of the case. The first version is presented by the defense.

\section{The Defense Attomey's Version of Sandra's Death}

This version has three primary components. First the defense attomey says that the victim, who is now dead, was not a good woman, but the defendant, who shot and killed her, is a good, taxpaying citizen. Then he says that the offender shot and killed her, not as a criminal, but as a good citizen who committed an accident which was the result of the convergence of alcohol, his emotional response to his wife's infidelities, and the presence of a firearm. The third component is that the offender has an illness and it is this illness, alcoholism, that caused the victim's death.

(Appendix F, Lines 73-77)

[Defense Attorney]: But at any rate, it goes without saying this is a time where robody wants to sit in youz [the judge's! chail tp there. This is obviously the hardest job a judge ever has.

You have got on the one hand a beautifui family, a kid who has worked ins whole ifie.. .

\section{(ines $79-86)$}

He has a fatal Elaw. He is an alcoholic. I've had him evaluared. He has met a couple times with Nick Gianpietro, a certified alcoho: evailiarcz. And based upon what happens today, it is obvious he has to be in some kind of program, whenever he is not incarcerated, if he is not incarcerated Erom the outset, or later on, he is going to need treatment for that. It is a disease that runs in the family.

And when you mix alcohoi, emotion, the incredible emotion of the situation he found himself in, and firearms, a tragedy happens. And Sandza leacock, for all her fragilities, it is a tragedy that she is deceased.

No evidence of the existence of the victim is before us except what is continuously referred to as her frailties, these frailties being that she is a gambler, that she drinks, that she is a poor mother, and that she has had, on more than one occasion, an affair with another man.

(Appendix F, Lines 102-106)

[Defense Attorney:] You know all the facts of this case. You know everything. The one thing you don't know is that he keeps working hard to co his obligations. One of the things. Sandra, because of her drinking, and sire had a gambiing addiction to playing Keno at these bars. Everybody says Kenc is a great thing, but she spent hundreds of dollars a day piaying Keno, of his money, her money. 
(Lines 130-135)

I would just say that I have talked to Mary Lemon, and MI. Defaven was nice enough to share with me a littie about what she said. She is a very religious lady. She prays for her daughter. If she were her, she would tell you about her daughter's frailties and how nice ken was to her son from a prior marriage. That son wasn't living with here because she wasn't considered to be a mother that could handle a son, and the grandmother, Mary Lemon, is raising that boy down in Texas. . . .

(Lines 78-79)

He marries a lady he is in love with, he has been married five years, and for the second time he finds her in this tragic situation lhaving sex wir: another man].

This picture of her is juxtaposed with that of the person who shot and killed her. We are told that he comes from a beautiful family, he is a kid, he has worked his whole life, he was in love with this woman, he has a flaw, he is an alcoholic with a disease. Next we hear about those who support her,

(Appendix F, Lines 90-95)

[Defense Attomey:] It is certainly appropriate in our situation with this beautiful family-the problem, he has got two brothers that are police officers, and I would worry about his safety down there. Bruce is a twentyyear veteran, Brian is an eight-year veteran. Brian served in Desert Storm. Kenny didn't become a police officer mainly because he started working and getting a real paycheck ever since junior high school. He has worked every day that he could his entire life, as you know. . .

\section{(İnes 97-99)}

Mr. Manifold [his employeri took the trouble to come down from Pennsylvania, he is in the back, the gentleman in the tie and coat, he took the trouble to come down here. He needs him to work. You have seen letters from his customers, he is nice and poizte. . .

\section{(Lines 112-113)}

He has paid his lawyer bills slowly and on time. I'm fully paid. The iandlord is being paid. He is just a tax-paying great member of society.

It is this draping Kenneth in the flag and adorning him with core American values such as being a hard worker, coming from a good family, and being a tax-paying citizen that creates the subtext that he is not a real criminal. Criminals do not come from beautiful families, they are not kids, they do not work (and if they work they don't work steadily and they don't work hard), they are not in love with their partners, they are not linked to the police in a positive way, they do not have brothers who participated in Desert Storm, and they do not have letters from customers who say they are nice and polite. Even though middle-class, white American businessmen are responsible for a significant amount of the criminal activity that occurs in the United States and commit most major financial crimes, the cultural image of a criminal is usually a person who is 
not white, not middle-class, and not hard working. Criminals are typified as poor white trash or people of color who have grown up on welfare, live off the state, and engage in violent behavior because they come from families with no true values. In this way the defense is putting forth the version that the offender is not a criminal but is in fact a good citizen.

The version of Sandra's death is simultaneously hooking into a larger discourse which has dominated U.S. media and politics since the rise of the right wing in the 1980s. It is counting on the listener/reader, in this case the judge, to make a conversion here. The defense attorney is speaking to the judge as a member of a professional community who knows how to organize the particulars that the defense is presenting. Sandra is to be blamed for the situation (Jones, 1980; Pagelow, 1981); Kenneth is to be understood yet not totally exonerated, and alcohol is to be blamed for how he reacted to the situation (Coleman \& Straus, 1983; Frieze \& Knoble, 1980; Eberle, 1982), as is his understandable rage (Gondolf \& Russell, 1986). The way men and women are organized into marriage, the role of economics, and the role of male entitlements in U.S. family structures are made invisible in these arguments. The effort by the defense attomey to link the violence to the alcohol, the rage, and the victim's behavior is available to be hooked into because there isn't a more powerful professional discourse in the field challenging these concepts.

\section{The State's Version of Sandra's Death}

The prosecutor, representing the state, claims that he will incorporate the state's argument into Sandra's mother's desires. He thus links the impersonal state to the personal, a mother's rational call for some punishment for the death of her daughter. Both the defense and the prosecutor, for their own respective purposes, present the mother as a good woman, not vindictive. Both selectively use her words to bolster their own versions. She is not physically present, nor does she present her own version. Instead four or five lines of conversation are extracted from interviews that were designed to elicit only certain kinds of responses from her and only limited information about Sandra, her relationship with her husband, and the history of their marriage.

The prosecutor is entering into a very tricky argument. On one level he, on behalf of the state, has agreed to allow a person who has admitted to killing his wife because she slept with another 
man to plead to manslaughter, a charge which implies the death is accidental. On the other hand, he needs to argue that this person must be punished for the accident. He does not question the premise of the defense's argument. He does not mention that infidelity to one's spouse in not uncommon in the U.S. (Michael, Gagnon, Laumann, \& Kolata, 1994). He does not ask who in his courtroom has also been unfaithful and then suggest that they are lucky to still be alive.

\begin{abstract}
(Appendix F, Lines 154-172)
[Prosecutor:] She indicated to me on one side, and I'm going to incorporate the State's argument of course along with this, but basically hex jeeling is the State's feeling as well, you[r] Honor. She indicated to me that on one hand she can see her daughter provoking the anger that it did, and causing the anger that later led to this incident. And as we talked all along about this case, I said, well that was the reason basically the state agreed to proceed on the manslaughter charge. The State believed that provocation was sufficient to proceed just on the manslaughter as opposed to the murder in this case.

And she talked about the other aspect of her feeings, and that is what the state is going to argue to you today, that the defendant should be punished for his actions. The defendant had an opportunizy to walk away lnat night. It is clear that the defendant decided to take matters into his own hands, to pick up that gun, to pull the trigger, and eventualiy took the Iife of another person. Mrs. Lemon indicated to me she believes this Court shouid punish the defendant appropriately.

The State believes that appropriateiy in this case means a sentence cf incarceration within the guidelines. They are three to eight years, your fonor. As the Court notes from the guideline sheet, nothing has to do wit: the offender score. The defendant up until this point, his ijfe, he has been an exemplary citizen. In fact, remains so even while out on bail awaitirg sentencing today. The state does not believe that really he is going to je a threat to society when he gets out. I do believe this is an isoiated incident.
\end{abstract}

Alternative discourses which the prosecutor could call upon have very little currency in the legal setting. For example, he does not refer to the notion that a batterer is not out of control but uses violence to establish control. The prosecutor apparently accepts the premise of the defense that murderous rage is understandable, that alcohol is a disease which turns nice guys into killers, and that Sandra provoked the assault. He doesn't challenge the assumption that Sandra needed to be punished, only that Kenneth was acting outside of accepted social bounds of punishing by taking the role of the punisher into his own hands. He never has to explain how Kenneth can be an exemplary citizen and will in all likelihood continue to be an exemplary citizen once he pays for this isolated incident. No one seems concerned for the woman in the courtroom who was earlier introduced as his new fiancée. 
(Appendix F, Lines 58-65)

[Defense Attorney:] He has got a wonderful family, many of whom are here. Eugene Manifold, his employer, is here, whose letter you have read, Bruce Peacock and his wife, Michelle. Bruce is the twenty-year veteran, whose letter you've read, Mike Hertzog, his friend, whose letter you have read, Barbara Bauer, his fiancée, Bruce Peacock, SI., the thirty-eight year employee of the Baltimore Gas and Electric company, who is Kenny's father, who is here today with his stepmother, who loves him dearly. You have read her letter, and Mr. Peacock, Sr.'s letter. His mom, Jane, is here coday, and İsa Stinson, a friend of the family. They're all here.

She is introduced as part of the entourage of people here to stand up for Kenneth as a good kid. It's hard to imagine a man recovering from killing a woman he truly loved and to whom he was a devoted husband, working as many hours as he could to help his mental state, and finding someone to propose to in such a short period of time. But those particulars are inconsequential here, and this woman's future safety is presumably not in question because she will not have the same frailties as Sandra had and he will most likely stop drinking.

\section{The Defendant's Version of Sandra's Death}

Kenneth talks about what has happened (lines 182-185).

"I'm very sorry about what has happened."

"I would like to continue working."

"Working ... helps me out mentally."

"I'm just willing to accept whatsoever you will do for my actions."

He follows the defense attorney's argument that he was not so much an actor here as a victim of a series of forces beyond his personal control. The holy trinity of batterer's defense attomeys appears here: alcohol, rage, and bad women. He then portrays himself as a hard-working, good man with simple needs. He shows deference to the judge's hierarchical authority in a display of humility and piety one wonders if Sandra ever saw. As thousands before him have done, he throws himself upon the mercy of the court. In his case he finds a more than merciful court, he finds another man who under the same circumstances would himself mete out some degree of corporal punishment. As the judge said in his sentencing,

(Appendix F, Lines 295-298)

[The Court:j I seriously wonder how many married men, married five years or four years would have the strength to walk away, but without infiicting some corporal punishment, whatever that punishment might be. I shudder to think what I would do. I'm not known for having the quierest disposition. 


\section{The Judge's Version of Sandra's Death}

The judge takes up the defense attorney's version but puts a frame around it that will authorize him morally, ethically, and legally to take an institutional course of action which simultaneously preserves male prerogatives and social status and allows him to claim that he has been objective, fair, and unfortunately harsh on the tax-paying kid before him. He is able to do all of this by framing the case as analogous with the manslaughter by automobile cases. Most of us who drink have feared getting caught with a slightly high blood alcohol count while driving. We have perhaps driven while drunk, later realized that we could have hurt someone, and thanked God for letting us escape such an accident. We have been educated by all of the public service TV ads and by Mothers Against Drunk Driving: we understand that hitting someone in the car while drunk is an accident but that getting into the car while drunk is a choice, and that therefore, what happens to someone who drinks and drives must be the responsibility of the driver. The judge equates Kenneth to such an individual. He sympathetically agonizes over the plight of a woman who killed her best friend in a drunk driving accident, the man who killed his brother, and the forlorn husband who killed a 10-year-old child.

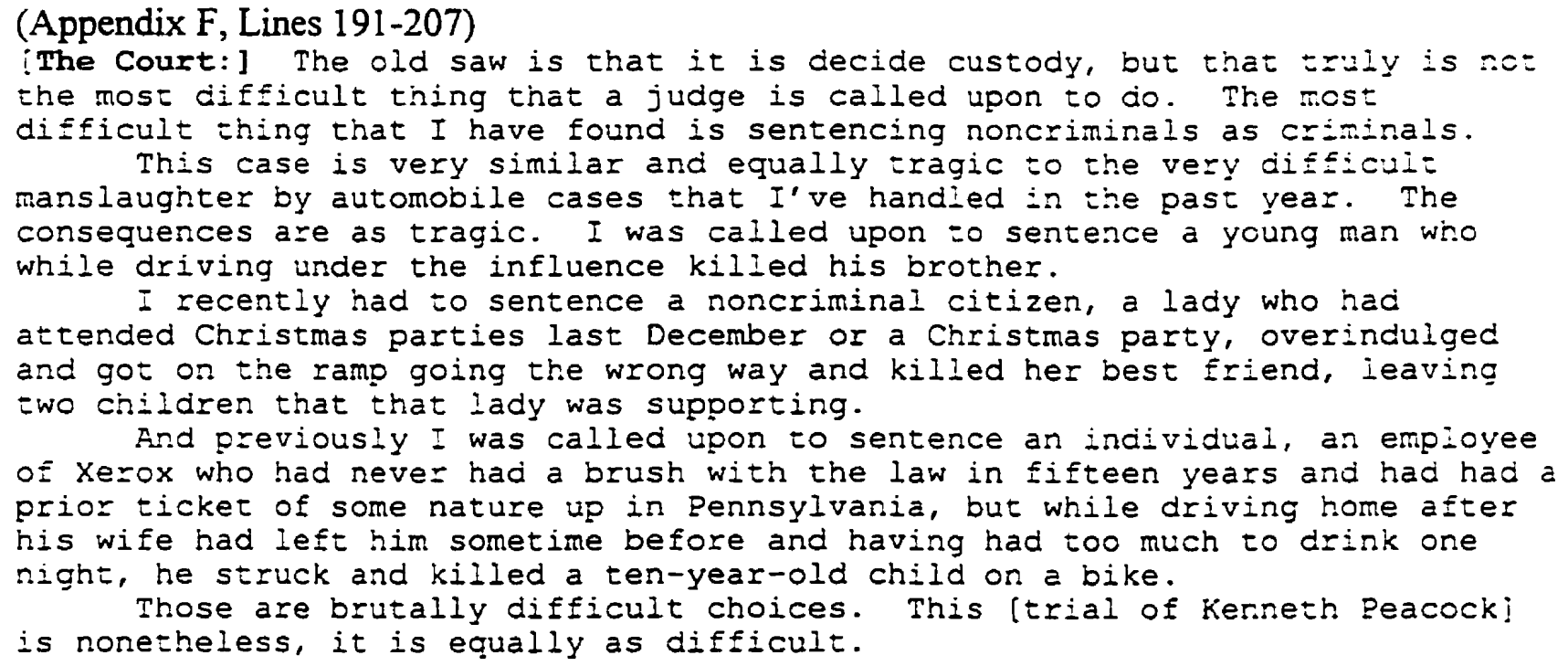

This likening the shooting of Sandra to a drunk driving death creates a sort of template, or frame, for the judge's ensuing remarks. He prefaces those remarks by expressing a bit of relief that he can sentence in anonymity because unlike drunk driving cases, no organization like Mothers 
Against Drunk Driving is present (line 208). He muses that perhaps because of the attention on spousal abuse, someone might hear of this case, but most likely he will be acting outside of the public eye (line 208).

The judge's accidental-death version of Sandra's murder was not one that he simply pulled out of a hat. It is probably safe to assume over his years on the bench he has heard cases similar to those that I've observed in Duluth's misdemeanor and felony criminal courts. A probation officer and victim advocate comment on the alcohol link in these cases.

At least three out of four cases I work involve drinking by the guy or both of them. So of course alcohol has a role in all of this. And I'm sure he won't quit [battering] until he stops his drinking. So I focus a lot of my attention on getting him into a treatment program that will work for him. - Probation officer (interview, September 29, 1995)

I'm so sick of these guys standing up in front of the judge with a false humility saying, "The booze did it, Your Honor, I'm sorry, I have it under control now." It's almost as if it's like a required script at sentencing for the defense attorneys or the batterers to say this.-Victim advocate (interview, June 15, 1995)

Below are excerpts from several sentencing hearings typical of the "script" to which the advocate above refers. Whether spoken by the client or by the defense attorney on behalf of the client, it is the most common explanation offered by offenders for their violence.

The first case involves two sentencing hearings of the same abuser, Lawrence Schul. One occurred in 1991 and a second in 1994. Mr. Schul had been arrested for several other assaults and had had several protection orders issued against him. He had been convicted of disorderly conduct previously for an incident in which he assaulted his partner and entered into a plea agreement for a reduced offense. Following are excerpts from the 1991 plea and sentencing hearings.

The Court: All right. Mr. Thornton.

[Defense Attorney]: Your Honor, I believe the recommendations are reasonable under the circumstances. If you do sentence him consistentiy with the recommendations, it's good to see that he has earned the benefit of the Colirt's Eaith in him by allowing him into the treatment program (for aiconolism] early, and the beneIit of the Probation Department's expertise in 
this matter.

Most importantly, I think from his point of view, if he drinks at ali from now on, the life as he's known it is over. He's going to lose his job, his girlfriend, he has everything to lose. This court is giving him an opportunity to gain a lot, so I would ask that you sentence him consister:iy with the recommendations.

I ask that he keep in mind the benefit that he's getting, not oniy from this Court and the Probation Office but from the Prosecutor's Office, as well.

The defense attorney sets the stage for the defendant to make the claim that drinking is his problem. It is a claim that neither the court or the prosecutor challenges. Mr. Schul will leave the courtroom convinced that he is not a batterer but a man with both a drinking and a woman problem. He articulates this to the court.

The Court: Mr. Schul, is there anything you wish to say?

The Defendant: Yes. I thank you for ietting me tc go ireatment witen you did. I realize I really did mess up. Before this incident happenec, I did try to get in treatment. I realized I was out of controi, and I wis: I would have gotten there before anything happened. I just appreciate your ietting me go when you did, into treatment.

The Court: Ms. Coker, is Mr. Schul in Miller-Dwan at che present izme?

[Probation officer]: Your Honor, he just completec the treatment at Miller-Dwan. I have got a confirmation that he did successfuliy complese the program there just last week. They also will be scheduling him for foliow-up treatment and aftercare.

The Court: All right. Mr. Schul, for the cxime of assault ir. the second degree, this Court is going to sentence you to the Commissioner of Corrections at Stillwater Penitentiary for the period of 2 i montis.

However, I don't think it's necessary that you serve that sencence at this rime. I'll stay the execution of that sentence, and I' i piace you or. probation for a period of three years. .

I will require, as you have already done, that you complete your chemical dependency treatment, and that you successfully continue with ary follow-up that they recommend, and successfully complete that.

During this period of time, I'll require that you use no alconoiic beverage, which includes 3.2 beer, and that you use no drugs or medicines uniess they are prescribed by a physician. I will require that you get yourself invoived in tise domestic abuse program. Ms. Coker can get that set up for you.

I've got to warn you, Mr. Schul, there will be other terms and conditions of probation.

Now, before you leave here today, I want you to talk to Mr. Ritzell and Ms. Coker, and they'll get you set up on your probationary program.

You got yourself a real break, so take advantage of it.

The Defendant: I will, sir.

Two years after this case, Lawrence Schul was convicted of a felony assault (his third conviction) and served 18 months in a local correctional facility. Shortly after his release, he was again arrested. The same defendant is once again before the court, this time for violating a no-contact order. This is the fourth time the court is sentencing Mr. Schul for a domestic violence-related offense. The defendant is explaining that nothing really happened. 
The Defendant: She was just upset and crying and. . . I don't know. I didn't harm her in any way. All I was tryin' to do is settle her down. All-you know, that's all. I got a new job. Iike I said, a friend of mine came up from ohio. I'm supposed to be leaving this weekend for-for a company called $F$ \& $E$ Incorporated. They clear for power lines and gas $l i n e s$ and a II stuff like that. And I just luckily got on. I've been locked up for over-almost a year, Your Honor. I just got out here a month or so back, two months back. All I want to do is get back on my feet. I lost a good joo ' cause of what happened over a year ago. I lsed to work for Burlingtorn. lost that, because of what I've done. (Pause.)

The Defendant: I won't be going to her house again, your Honor. I won't even be in town.

The Court: Just a minute. Let me read through the reports here. Just take it easy. . . .

Okay. Does the Probation Office have a recommendation in this matze:?

[Defense Attorney]: Yes, we do, Your Honor. Just to recap for the Colrt. He-Mr. Schul just recently got out of NERCC [Northeast Regional Corrections Center] about a month ago. He was there for a Second Degree Assault involving the same victim and also for a violation of probatior. wiscr. resulted from a drinking incident.

He indicates that he is aware of the OFP, that juila Adams knew he was planning on leaving town, he said, this weekend. He ran into Julia Adams yesterday. She invited him to the house. And she was intoxicated. He had a couple drinks himself, although he indicates he wasn't intoxicated. تe indicates that she started to cry and got upset over someting. He doesn't know what. And it just seemed to accelerate from tiere... .

The probation officer conveys Lawrence Schul's version of the offense to the court without questioning its validity. Here we see the problem with a system that sees the offender, not the victim, as the client. If, as an advocate suggested earlier (chapter 3 ), the victim was the client of the probation officer, this report would most likely be radically altered. That is not the case, however. The probation officer continues his recommendation.

[Defense Attomey:] At this point we would be máking a recommendation that-possibiy that Mr. Schul be given a-a sentence of seven-something iike 60 days in the County Jail and-and stay all but about four of those cays for purposes of him being allowed to find a job in Ohio. He incicated trere is a friend of his in town now [who] he was planning to going back to ohio with this weekend. He doesn't know exactly when. He doesn't know where to get ahoid of this friend, and he can't verify what time his friend wants co leave. So I don't know how he canthe can handle that situation. But I think after spending a couple days in jail, I think that he needs to be given an opportunity to make that start in Ohio where he says he has a job ined up, especially since there doesn't appear. .

The Court: The Court having accepted Defendant's piea of Guilty, is going to impose a sentence of three days in the County jail. Defendant wili be given credit for yesterday and today. . . Let me suggest to you you really want to do that, because every time you stick around here-

The Defendant: I know.

The court: -and you see her, you get in trouble. And you always wind up eithez in jail or NERCC, and she's sitting out there in her apartment drinking beer or whatever she does. I don't know. It seems to me that at some point, you know. you got to, you know, have the lights go on and say, you know, this doesn't make sense. 
Honor.

The Defendant: No, it don't. That's one reason I'm leaving, Your

The Court: Okay.

[Defense Attorney]: Thank you, Your Honor.

that.

The Court: 7:00 $0^{\prime}$ clock tomorrow we're going to give you a chance ro dc

The Defendant: Thank you.

There seems to be a consensus by two judges, one probation officer, and two prosecutors that the problem here is not men's entitlements in these private relations with women or how men use intimidation and violence to maintain or enforce those entitlements, but it is alcohol or the mixture of alcohol, anger, and problematic women.

The second case involves a man who has pled guilty to fifth-degree misdemeanor assault against his partner, who has since left him. It begins as the judge questions him about the incident. I've selected excerpts related to the defendant's rationale for avoiding jail time despite his previous assaults against this woman and another woman. Again we see the introduction of the claim, "I'm a problem drinker, not a woman abuser."

The Court: She reported on that occasion that you had shoked her ar:d pushed her into a wall; is that what happened?

The Defendant: I don't believe I choked her-and I huried her agains: the wall; I didn't push her. Those walls was-just leaning sometimes; you can. crack them-or it's kind of foggy because I was under the influence of alcohoi. Since then I haven't had a drink or any drugs or anything iike that. I've taken an alcohol assessment, and I'm working with the counselor and I have been in anger control class, and stuff. I am currentiy [at! work with socia: services to try to get the chilcren placed back in the home. I'm doing comunity service hours. I've been keeping-regular contact with my probation officer. . .

[Prosecutor]: I think you should add more time than just cer days.

The Defendant: I don't plan on having anything to do with her whatsoever. My main probiem has been alcohol. I'm getting help with that. I've been off of it for nineteen or twenty days. My priorities are reversec.

But I just want to get my stuff together with my kids and run the home. As long as I stay away from alcohol, I don't seem to have problems with. anything.

The Court: Ever been through treatment?

The Defendant: No, I haven't. That's been recommended. I was trying to get the child custody, and stuff, out of the way. I had a Rule 25 assessment and they determined there wasn't a dependency, but there was signs of abuse. I agree with that. . .

The Court: Have you had a previous assault convicrion?

The Defendant: No.

eise.

[Prosecutor]: I was told there was another assauit charge by somebody

The Defendant: There had been one made but it was dropped by the court. This was no evidence. But I meant her no harm. I don't know why she's crawling on me so bad. I want to get my life back in order and raise my 
children like I should have been doing the whole time...

The Court: 90 days county jail. Stay the time in favor of a year of

supervised probation. Conditions being that you abstain from the use of

alcohol; foilow though with any recommendations from your Rule 25 . .

Throughout these examples, alcohol is coupled with the notion of men having buttons, or breaking points, which unleashes an uncontrollable anger and rage. It is the combination of these factors which explains the violence and directs the response of the state to those who use it. This framework for understanding men's violence against women is one that has been formulated in the discursive practices of the human science and social service apparatus. In the case of Sandra Peacock, the Judge, the defense attomey, and the prosecutor all link into this discourse. Before returning to the case of Sandra's murder I want to talk about how these extended relations of ruling enter into this courtroom setting.

\section{Linking to Extended Social Relations}

The battered women's movement has spent much of its energy trying to offer altemative discourses to the much more powerfully entrenched discourses of the ruling apparatus. As discussed in chapter 2, for a brief period of time we dominated much of that discourse, but as research dollars became available and domestic violence became a popular field of study, the grassroots voice which used the media, newsletters, and training manuals as a form of discourse was subsumed under the discursive practices of academia and the U.S. human service and legal professions. Researchers in this field are entrenched in the ideological practices of sociology, psychology, and criminology. Russell and Rebecca Dobash, in their 1992 book Women. Violence and Social Change, describe the impact of the psychological discourse on the work of the battered women's movement:

The psychological and psychiatric professions are now extremely important in the United States and there has been a rapid rise in the number of professionals engaged in delivering therapeutic services. There were only 12,000 clinical psychologists in the United States in 1968 , by 1982 there were over 40,000. Today, about one-half of the world's clinical psychologists are working in the United States....

The rapid expansion during the nineteenth century of institutions of confinement in Europe and the USA provided a significant impetus to the behavioral sciences and the therapeutic professionals associated with them. This was the age of the great confinement and the rise of the cercarial or discipline society.... 
If the nineteenth century was the period for the rapid expansion of institutions and the growth of institutional psychiatry, the twentieth century has been a time when the professionals who created and operated these institutions have found their way into the general community....

Around the turn of the century social welfare workers in Britain and the United States began to seek professional legitimation by shifting their emphasis from merely helping and aiding the poor within communities, to various forms of casework counseling linked to 'scientific' interventions associated with psychiatry and psychology. Alignment with medical psychiatry gave professional status and legitimacy to the otherwise pragmatic work of social welfare agencies. Psychiatric perspectives played an important role in shifting the focus away from the social and economic conditions which produced the slums and depriving conditions of social work clients, to a focus on the personalities of the poor. Emerging individual perspectives grounded in the embryonic professions of psychiatry and psychology conceived of poverty and crime as primarily linked to individual pathology and inadequacy. This shift had a profound influence on the course of social work in the United States, making it difficult to consider the common bases for most social and economic problems. (pp. 215-219)

Practitioners are organized to think and act by the discursive practices extralocal to their everyday work setting. The social relations that organize individual practitioners' work are visible neither to the observer of the daily work practices in a local courthouse nor to the worker, but they are discoverable as the textual character of ruling and managing is explicated. As I have discussed, workers in the legal system are assigned duties that are highly specialized and routinized. Generally speaking, frontline workers prepare cases for resolution at a higher level of decision making. These workers process cases in standardized ways. To orchestrate the processing of a case involving many people with many different viewpoints, procedures are put into place which create institutionally acceptable actions on the part of practitioners. Limitations of the ability of individuals to act independently from institutional norms are constructed through the use of procedures, rules, regulations, promotional practices, and professional training. While court practices are carried out in local settings, the obstacles battered women face in getting what they might think of as justice or protection are encountered in courthouses across the nation. As D. E. Smith (1990b) argues, "Social consciousness exists now as a complex of extermalized social relations organizing and coordinating contemporary society. It exists as co-ordered practices and can be investigated as such" (p. 8).

Officers and all of the succeeding practitioners who enter a case operationalize certain methods 
of thinking about and interpreting what they are seeing and hearing. It is these methods of thinking that determine how practitioners will select, order, interpret, and record an account of the situation. Each practitioner who enters into the case will be institutionally organized to order, select, and interpret information to both read and produce texts. The ability to subsume individuals' commonsense knowledge and perhaps intuitive reactions to a case under an institutional interpretation of the situation characterizes the way institutional relations are ideologically accomplished. Workers are organized into a method of thinking about the people they work with that is rooted in theoretical models that borrow observations from the actual lives of women but are never accountable back to those experiences for their validity.

This method of thinking causes practitioners to replace a women's primary narrative with an account that gives her what we might think of an institutional legal existence. The psyciliatric system uses a similar method but gives her a psychiatric existence; social workers bring her into existence as a welfare recipient or troubled mother; medical personnel know her as a patient. Though each discovers her and makes her actionable in very different ways, the method of thinking that facilitates this way of ruling is common to them all. It transports the woman from her existence as a subject in her everyday world to the object of institutional action in their everyday world. These methods are so entrenched in the workings of the system that they seem natural. They are viewed as objective, while advocates, who articulate a political commitment to women's autonomy, are seen as ideological.

D. E. Smith (1990a) draws on Marx, especially his work in The German Ideology, to explicate these methods of thinking:

Ideas and concepts as such are not ideological. They are ideological by virtue of being distinctive methods of reasoning and interpreting society. . . .

To treat assumptions about human nature (among other concepts) as active forces in social and historical processes is an ideological practice. . . . Concepts, ideology, and ideological practices are integral parts of sociohistorical processes. Through them people grasp in abstraction the real relations of their own lives. Yet while they express and reflect actual social relations, ideological practices render invisible the actualities of people's activities in which those relations arise and by which they are ordered. (pp. 3637) 
When the actualities of people's activities are made invisible in these cases, women's lives are literally endangered. There is no way to fully see the violence or the meaning of that violence in the woman's or the man's life. In her description of D. E. Smith's use of Marx, Sylvia Hale (1990) points out the power of this method and capsulizes Marx's description of ideological practices in The German Ideology:

The creation of an ideology involves three distortions or tricks. First, real data, real experiences are noted. Secondly they are embedded in abstract conceptual schemes. Finally, these abstract models are treated as causal forces, and imposed as explanations for behavior. The original relations between people are covered up. This is a powerful way of controlling people because the logical models do indeed seem to fit the original data. People believe them and become obedient to them. (p. 246)

Practitioners in the legal system are directed through a system of professionalism and bureaucratic management to think in these prescribed ways. Class, gender, and race privilege are sustained not by the overt imposition of a specific bias but by ideological practices that produce methods of thinking about people's actual lives. The Canadian psychologist Donald Dutton became a media darling after his testimony in the preliminary hearings of the O.J. Simpson trial. In his book (1995) The Batterer: A Psychological Profile, Dutton claims to have uncovered a profile of the serial batterer. While his book sold well, it was his media fame following the Simpson trial that helped promote his theory that early childhood trauma causes men to become serial batterers. Dutton was interviewed about his theory in relation to O.J. Simpson in a popular Canadian women's magazine. ${ }^{47}$

Three traumatizing factors in early childhood development seem to produce an adolescent "ticking bomb": a shaming or disparaging father who regularly humiliates the boy, often in public; an insecure attachment to the mother figure, which produces a "Madonna or whore" perception of all women; and experiencing or witnessing an abusive home environment. As far as [Dutton is] concerned, Simpson fits the profile to a $T$ : "His father left home when O.j. was a kid, and the scuttlebutt around the neighborhood was that the

\footnotetext{
${ }^{47}$ I am using this interview in a magazine rather than Dutton's published work because this is how his theory enters the jury pool and popular thinking. In his book he says, "I believe most intimate abusiveness committed by men stems from ... deep-seated feelings of powerlessness that have their origins in the man's early development. With a shaming, emotionally rejecting or absent father, the boy is left in the arms of a mother who is intermittently available but whom he perceives as all-powerful. He never recovers from the trauma" (Dutton, 1995, p. 121).
} 
father was gay. His mother went out and worked 16 hours a day to keep a roof over their heads and meals on the table, so she wasn't available to him much of the time. On top of that, he had rickets. The neighborhood kids would call him Pencil Pins, and because there wasn't much money, his mother made homemade braces for him. So he experienced extreme shame, I would think - from the deformity, to the homosexual father who leaves home, which is the ultimate rejection, to the mother who tries but isn't available. With the shame comes rage, which doesn't go away just because he wins a football scholarship and goes on to become an American celebrity. The personality splits, and the rage goes underground. (Keyes, 1996, p. 57)

The practice of moving from actual observables to fabricated schemata that selectively utilize those observables to support causal explanations is an ideological practice in that "original relations between people are mystified, covered up" (Hale, 1990, p. 246).

The original relations between people in Simpson's childhood as well as within his marriage are being covered up in Dutton's method of thinking about and representing a version of Nicole Brown and Ronald Goldman's murders. Dutton's testimony is meant to affirm that Simpson fits the picture of a violent man, but in doing so he perpetuates a representation of men as out of control of their rage and women as bringing this rage on. Violence as a product of men's historic social and economic position of authority in the family is obscured in this analysis (Paymar, 1993; Gondolf, 1985). Dutton engages in several activities here that exemplify how battered women's actual lived experiences are denied expression in these discursive practices. First, his alleged theory on childhood trauma acts as a filter which will not allow into the picture most of what there is to see. The many particulars of Simpson's life and relationship with Nicole Brown, including those which contradicts his theory, are dropped from view. His theory acts to select the particulars readers will use as the original source of data. Dutton is not required to test it against the actual experiences of Brown or Goldman or Simpson because the theory itself has become the gatekeeper of information. Simpson will be squeezed into his theory, and not very neatly in this case.

Dutton's theory calls for a child to witness abuse or violence as a child. He claims that Simpson fits his theory to a $T$, but we know of no witnessing of violence. He shows absolutely no evidence of Simpson's having an insecure attachment to his mother, but uses the fact that she worked long hours as evidence of an insecure attachment. Finally, he apparently has no data to 
show that Simpson's father was actively engaged in humiliating or disparaging Simpson. He uses the possibility of his father being gay to assert that Simpson was regularly humiliated or shamed. He adds to this a guess that having rickets was humiliating but doesn't let us know how that might be tied to his father humiliating him. In short, the description that "fits to a $T$ " fits more like an X, but it doesn't matter because these people are not present in the discursive practices to correct the misrepresentations. If Simpson is an excellent example of his theory, what man couldn't be manipulated into it?

The Simpson's interviewer fails to note the extent to which Simpson has to be crammed into the Dutton theory but does authorize Dutton's account by listing for us his credentials. Dutton

is a Vancouver psychologist who testified for the prosecution at the Simpson trial's preliminary hearings ... He recalls being cross-examined by F. Lee Bailey one of Simpson's "Dream Team" [lawyers] ... An author and professor of forensic psychology at the University of British Columbia ... he was asked by the Vancouver police force to help modernize its officer training ... "For two years I spent every Friday night riding on patrol"... Based on his research and experience ... (pp. 56-57)

Dutton's approach exemplifies here the ideological practices Marx explicates in The German Ideology. Trick one: Note real data and experience (batterers often have childhood experiences that could be represented as trauma). Trick two: Make up an abstract conceptual scheme into which real data can be embedded (humiliation by father, insecure attachment to mother, and witnessing violence produce a childhood shame that turns to rage by adolescence). Trick three: Treat this abstract model as causal to the observation (Simpson had a deep well of rage that turned him into a batterer and in this case perhaps a killer).

In the same interview Dutton claims that battering has a typical cycle and goes on to describe Lenore Walker's "cycle of violence" theory:

The typical cycle of domestic battery goes from a gradual build up of tension to an explosive release to a period of I'll-never-do-it-again remorse that [Dutton] says can sometimes seem like a seductive honeymoon. It's a pattern that can promote a strong form of bonding .... (p. 58) 
Walker's theory (1979), described in chapter 5, uses the same method of thinking as Dutton's. Interestingly, she was called upon by the Simpson defense to work on the trial preparations. After forty hours of interviews with Simpson, Walker, who has never been an expert on working with abusers, announced on several nightly talk shows that she was quite prepared to testify that Simpson did not fit the profile of a man likely to kill his wife.

Several legal theorists (Bersoff, 1986; Tremper, 1987; Faigman, 1986) have discussed the increasing role of the "psy" professions in shaping legal discourse and influencing how practitioners and juries understand the cases before them. It is the interlocking nature of these conceptual practices that contributes to the hegemonic control of what becomes seen as masculinist interests in the legal system. Dutton and L. E. Walker are not apologists for the legal system. Both have been actively working to reform court processes to make them more protective of women. Social scientists and practitioners engage in these practices because they are fully entrenched in the common ideological practices of knowledge making.

\section{Was Sandra's Killing an Accident?}

I have used four sentencing hearings, including the sentencing of the man who killed Sandra Peacock, to explicate how the discursive practices of the social sciences, particularly the "psy" literature, intersects with the documentary practices of court practitioners to produce accounts of men's abuse of their partners. In the hearings cited in this chapter, these discursively manufactured explanations of battering create a boundary around institutional inquiry that consistently discounts the danger that women experience in relationships with men who use violence. These frameworks individualize what is social and decontextualize "incidents." Yet the use of violence must be contextualized if victims are to be afforded adequate protection. In Kenneth's case we have a judge, perhaps a middle-aged man, presiding over a hearing about a woman's death. The prosecutor, a man with a law degree who must have seen hundreds of cases of women being battered, speaks for the state when he tells us that the man who shot this woman is not dangerous. Also in the room is a court reporter who has been silent throughout the whole proceeding and is married to the defense attorney. The courtroom is filled with Kenneth's friends, family, employer, and fiancée, all of whom are there to say he is a good guy. 
Most men who kill their wives do so because their wives are leaving them. Most women who kill their husbands do so because their husbands are beating or raping them (Jones, 1980; Browne, 1987). Gay men kill their partners, and lesbians kill theirs. However, this sentencing hearing is conceivable only in the case of a man killing his wife. The historical legal right and obligation of a man to chastise his wife is rooted in heterosexual male privilege (Dobash \& Dobash, 1979) and is the basis for the prosecutor's decision to reduce charges, the defense attomey's decision to argue that his client should serve no time, and the judge's decision to impose the lightest sentence possible for such an act of violence.

Let's look beyond this courtroom scene to a few years in the future. Three years from now Kenneth will be off probation, he will have served his sentence, and he will likely be married to Barbara Bauer, the woman introduced as his fiancée. If he hits her, she may seek help, perhaps a protection order. The clerk of court or the advocate who helps fill out that protection order will undoubtedly have private thoughts about the woman before her, a woman who is surprised that her husband, who killed his first wife, is being violent. As the clerk helps to fill out the forms she will be asking herself, What did she expect marrying a man who killed his first wife? Is she crazy? Did she think she could bring out something in him that Sandra couldn't? Did she have so little self-esteem? Was her denial so high?

The judge has said that Kenneth is a non-criminal. The prosecutor has said that the level of provocation was such that we could not call this murder. The employer says he's a great customer pleaser. None of these men will be implicated in the indictment of the young woman who is seeking protection from a man who killed a previous wife. A new framework will be applied for her. This framework will also be borrowed from the "psy" profession. This time we will look at what self-defeating personality disorder led her to choose such a brute.

William Ryan, in his classic 1972 book Blaming the Victim, explains why victim blaming is so pervasive in these types of settings.

The victim blamers turn their attention to the victim in her post-victimized state. They want to bind up wounds, inject penicillin, administer morphine, and evacuate the 
wounded for rehabilitation. They explain what's wrong with the victim in terms of social experiences in the past, experiences that have left wounds, defects, paralysis, and disability. And they take the cure of these wounds and the reduction of these disabilities as the first order of business. They want to make the victims less vulnerable, send them back into battle with better weapons, thicker armor, a higher level of morale.

In order to do so effectively, of course, they must analyze the victims carefully, dispassionately, objectively, scientifically, to see what made them so vulnerable in the first place.

What weapons, now, might they have lacked when they went into battle? Job skills? Education?

What armor was lacking that might have warded off their wounds? Better values? Habits of thrift and foresight?

And what might have ravaged their morale? Apathy? Ignorance? Deviant lower-class cultural patterns?

This is the solution of the dilemma, the solution of Blaming the Victim. And those who buy this solution with a sigh of relief are inevitably binding themselves to the basic causes of the problems being addressed. They are, most crucially, rejecting the possibility of blaming, not the victims, but themselves. They are all unconsciously passing judgments on themselves and bringing in a unanimous verdict of Not Guilty. (p. 28)

Kenneth Peacock's sentencing hearing shows how the legal system connects into extended relations of ruling. The actual lived experience is subsumed under the ideological practice of a ruling apparatus that shapes the lives of women and in this case declares that Kenneth Peacockwho sat for almost two hours talking with his wife after discovering her in bed with another man, finished his discussion with her, picked up a gun, pointed it to her head, and shot her, causing instant death-did so accidentally. Heterosexual men can't help shooting wives who are unfaithful. 


\section{CHAPTER EIGHT \\ POLITICS OF CHANGE}

I am concerned that the story I have told here might imply that battered women and those who intervene to stop the violence against them are being totally controlled by documentary practices and that both are powerless to change this. This is not an accurate picture of what occurs. Individual women, intervening practitioners, and advocates all engage in concrete actions to control or interfere with these practices so that the process doesn't control them. In chapter 3 I provided an example of this with a transcript of a prosecutor's attempt to stretch the confines of the system: she prosecuted a man who had repeatedly assaulted and threatened his wife, although the incident for which he was arrested had been constructed as a mere argument over possessions. Another example of attempting to control documenting practices is that for years shelter advocates have kept only minimal records of women using their facilities in order to avoid being subpoenaed to appear at a court hearing in which information might be used against residents. At the same time, they have argued for increasing the documentation of men's violence. Ensuring that practitioners involved in these cases notice and document the violence is seen as a method of compelling them to take more protective action, if for no other reason than to avoid liability should someone "get hurt."

I am mostly interested here in ways advocates can promote changes in the system by resisting what seems to be the hegemonic control of ideological practices embedded in textual processes. Sociologists are recognizing that social change doesn't necessarily come in the form of class warfare, as Marx and others might have argued, but through undermining the countless expressions of power in micro processes of managing social institutions of ruling. Within the battered women's movement there have been many successful attempts to control these discursive practices. Like activists in the broader women's movement, advocates have recognized that if we can claim the recording process for the benefit of battered women, we can avoid succumbing to methods that benefit the interests of the institution as an apparatus of ruling with no regard for a woman's safety.

In this chapter I will describe an effort to claim these documentary practices for the benefit of 
battered women by changing a single processing interchange and work setting.

It would be difficult to say I finished my research on a particular day or in a certain month. But there was a point in which I stopped being a researcher, looking for the how, and became an activist, advocating for changes. I talked with my co-workers about concrete ways we could make changes based on the many ways I had come to see documenting practices marginalizing women's safety. It would have been practically impossible to propose changes at every point of case processing, so we decided to begin where we had our best links to practitioners in the system, the probation department. I approached the agency director about working with the adult misdemeanor unit of the department. He and the unit supervisor agreed to work with me and my co-workers on a strategy to improve the department's attention to victim safety. We saw the presentence investigation (PSI) as a crucial point in addressing victim safety and a good place to start proposing some changes in documentary practices.

The Presentence Investigation

The court assigns a case to a probation officer after a trial or a negotiated plea agreement. Most cases are resolved through a negotiated agreement between the prosecutor and the defense attorney. In its most basic terms, such an agreement entails an offer by the prosecutor to the defense attorney along the following lines: "You have your man plead guilty to fifth-degree assault, and I'll drop the other two charges against him: violation of a protection order and criminal damage to property. We'll have a presentence investigation conducted and we both agree to abide by the recommendations of the probation officer." Or, "I have a victim who wants to testify, pictures, a police report that is extremely thorough, and a 911 tape that the jury would love to hear. I'd suggest you have your man plead guilty." If there is only the assault charge and not such a great case the prosecutor might phrase the agreement, "You have your man plead guilty, and I'll lower the charge from assault to disorderly conduct. We'll have a presentence investigation and both agree to the recommendation of the probation officer. "Judges can refuse a plea agreement if they think it is not in the interest of justice. However, they cannot prohibit the prosecutor from dropping a case or require a prosecutor to charge a case. In Duluth, the prosecutor dismisses approximately $22 \%$ of domestic assault-related cases for lack of evidence. Of the remainder, $95 \%$ are resolved through such a negotiation process. Only a handful of 
misdemeanor cases go to trial (Duluth chief prosecutor, interview, May 8, 1996).

Minnesota state law requires judges to impose a fine for all crimes involving violence. Lowincome defendants can work off their fines through a community work program. The Duluth DAIP conducts a 27-week course on nonviolence. Completion of that course has become a standard condition of probation for domestic assault offenders. While each probation officer has a distinctly idiosyncratic style of reporting the PSI process, the resulting recommendations to the judge were essentially the same.

I began working on a proposal for changing the PSI process by watching a probation officer conduct a PSI. The day I came to observe, the courtroom and the hallway were packed with defendants and their friends. One hundred thirty-nine cases were scheduled to be disposed of between 9:30 a.m. and 3:30 p.m. Ten defense attorneys were wandering around in the hallway calling out the names of clients, while watching for a private moment with the prosecutor. As defense attorneys huddled with clients, the prosecutor stood toward the front of the courtroom near his table. He had the 139 case files arranged before him according to some plan. Defense attorneys were constantly approaching him. As the prosecutor looked for the relevant file, he and the defense attorney would hold a brief conversation in hushed tones. This had gone on for about 40 minutes when the arrival of the judge was announced and everything came to an abrupt halt. We all rose as instructed by the bailiff and then sat down as instructed by the judge.

This, it occurred to me, was what John at the dispatch center was talking about when he said the system subdued the man. The building, the organized chaos, the rituals, and the suited lawyers representing mostly working-class and poor men all combined to create an ambiance of authority.

As the first case was called, both the prosecutor and the defense attorney approached the bench. The defense attorney began to explain to the judge that he had made an arrangement with the prosecutor. In some cases there had been no arrangement, in which case a trial date was set. In more than half of the cases the defense attorney and the prosecutor had reached an agreement.

The first domestic-related case that day came up about 40 minutes into the proceedings. It was 
the case of Darrel Stanik and Michelle Lake. Darrel Stanik's attorney explained to the court that Mr. Stanik was going to be pleading guilty to a charge of disorderly conduct. Both the prosecutor and he would accept whatever recommendations the probation officer made for sentencing. The judge handed a file to the clerk. The clerk held the file out in front of her and the judge said, “Okay, Mr. Stanik, I'll have a probation officer conduct a presentence investigation with you and then this afternoon we'll have your sentencing. If you want to go then with Ms. Downer, she will conduct the PSI on this matter."

Here two attomeys presumably pitted against each other in an adversarial contest were submitting to the unknown recommendations of a third party. It seemed to me that individual probation officers have a great deal of power.

Sharon Downer was standing in the doorway. She came forward as the judge mentioned her name, took the file that the clerk was holding out, and motioned for Mr. Stanik to follow her. A shelter advocate followed them out the door, as did I. The shelter advocate motioned to Sharon that she wanted to have a word with her. Sharon turned to Mr. Stanik and said, "Can you just wait here a few seconds? I need to talk to someone." He nodded and Sharon walked a few feet away with the advocate. They exchanged a few words and parted. Sharon came back to Mr. Stanik and asked me if I would be joining them, and the three of us headed for the elevator.

Later, I found out that the advocate had told the probation officer that, after the incident, Michelle Lake, the victim, had obtained an OFP, which excluded Mr. Stanik from the home. She also informed Sharon that Ms. Lake did not want him back in the home or for him to have any contact with her. This information was eventually incorporated into the probation agreement under condition number seven: "Obey all court orders, including the current protection order and any of its future modifications."

The probation officer sat at her desk, and Mr. Stanik sat next to the door at the side of her desk. I sat in a comer, off from both of them. I noticed that the defendant sat between the probation officer and the door. This arrangement did not conform to the safety protocols of larger probation offices, which advise probation officers to make sure they can leave the room first. 
Sharon began her interview with a brief explanation, saying, "We're here to get some information on your background so that the judge can sentence you appropriately. This is a presentence investigation and if the judge puts you on probation, I'll be your probation officer. I need to ask you some questions so I can make a recommendation to the judge, is that O.K.?" Mr. Stanik nodded. She then began to ask questions directly from her PSI form: his name, his birth date, his race, his place of birth.

After these few questions, Sharon sat back in her chair and asked, "How long have you lived here, Mr. Stanik?"

"Three years," Mr. Stanik replied. They chatted about different places he had lived, then she asked him to wait a bit while she checked on some information.

When she walked out of the room, she left his file on her desk. I wasn't sure what was in the file, but I wanted to grab it. I thought there might have been something in there from the woman he had assaulted or from the shelter. I wanted to follow Sharon out of the office but decided to stay in the room with Mr. Stanik so he wouldn't look in the file. Sharon, I later learned, ran a record check for the three states he had mentioned in their conversation. It would take about 15 minutes for the report to come back.

She came back in the office and completed the interview. During that time, she asked several more questions from her form: his military background, family of origin, education, place of employment, income, length of employment. She looked up, leaned back, and began another chat with him. "So what happened here, Mr. Stanik?" She picked out the police report from the file and skimmed it while he began to talk. He started to relate the events of the evening the police had arrested him. She interrupted him several times, pointing out discrepancies between the police report and what he was saying. He explained each discrepancy but seemed to be trying to stop short of saying the police officer who wrote it was lying.

They discussed the incident for a few minutes and then Sharon asked him more questions: did he drink a lot, had he ever been to treatment, did he spend much time gambling, and had he ever 
been in counseling for any reason? He answered that he drank infrequently but occasionally did get drunk. He had had a DWI in the past but had never had any sort of counseling. Occasionally, he played poker with his friends; however, he did not gamble in any of the casinos. Then Sharon asked what kind of drinking there had been in his family. Had he ever been a victim of abuse as a child, or had he witnessed abuse in his family? His father had frequently pushed his mother around, but nothing that ever resulted in any kind of "police action or arrest or ambulances or anything like that." Had this been the first time he had ever assaulted Michelle? They had both "gotten into it a few times before, but not to have the police called." Sharon asked a few remaining questions from the form and then asked him to wait in the chair in the hall while she talked to Michelle. He told Sharon where to reach Michelle during that time of day and stepped out of the room. She called Michelle at the number he had given her but there was no answer. She found another number in the police report, but no one answered at that one either.

Sharon went to get the results of his record search, came back to her desk, wrote for about 5 minutes, and then asked the defendant to come back into the room. She asked him about the DWI conviction in 1989 in St. Louis County. He said that they had taken it off his record, but she told him they had not. He asked her what that was going to mean as far as this conviction goes. It probably would not make a difference in terms of doing any time in jail, Sharon explained. However, because he was drinking the night of the incident and had a DWI, she was going to recommend to the judge that he have a chemical dependency evaluation and follow whatever recommendations the evaluator makes.

She asked him if he had ever been to counseling for abuse and described the men's educational program at the DAIP. She said she would also recommend that program as a condition for his probation. She would not recommend any days in jail beyond the 2 he had already spent there following his arrest. The judge would probably put him on probation for a full year. She then quickly ran through the conditions of the probation she would be recommending to the judge and asked if he understood each of those conditions.

He said that he understood each condition. She asked him again to wait in the hall while she finished her paperwork. After about 5 minutes filling out two forms Sharon said, "That's it. 
Let's go see the judge." We picked up Mr. Stanik and the three of us walked to the courtroom. When the case was called again, the judge turned to Sharon and asked if she had completed the PSI. "Yes, Your Honor, I have," she told him and she went on to make her report.

Appendix $G$ is a copy of the presentence investigation form Sharon completed as she interviewed Mr. Stanik.

The judge sentenced Mr. Stanik to 60 days in the county jail, 2 of which he had already served. The judge stayed the remaining 58 days and placed him on probation for 1 year. He asked Mr. Stanik if he understood the conditions of probation that the probation officer had recommended. Mr. Stanik replied, "Yes, Your Honor, I do." The judge said he hoped that Mr. Stanik would take advantage of the programs. If he failed to follow through, he faced spending more time in jail. That was the final disposition. Appendix $\mathrm{H}$ is the conditions of probation document that he signed. A year from now, when Mr. Stanik is "off paper," as probation officers say, the case will be closed.

When the sentencing was over, Sharon and I returned to her office and discussed the process. She asked me what I thought about it. I told her I was surprised how little discussion there had been about the kind of violence the defendant had used against the woman. I also noticed that the only attempt to talk to the victim occurred during a 10-minute period during the PSI. I asked why the department didn't allow more time to conduct these investigations. She explained to me that having same-day sentencing has its advantages: it moves the cases along quicker and the defendants are always there for an interview. However, the lack of preparation time is a drawback. In more than half the cases she is unable to reach the victim. She explained that in gross misdemeanor and felony convictions, probation officers have several weeks to prepare the PSI and thus have more time to try to reach the victim. We agreed that the PSI might be primarily a record check and a quick assessment of the defendant's attitude, but that other information that could inform the court-for example, the danger this person posed or all the harm done to the victim - was not available to the probation officer during this process.

I asked Sharon if she thought that this was an adequate process for the court to make informed 
decisions on sentencing misdemeanor offenders. She thought that it was "totally inadequate," but that it was still better than what other communities do. Many of them do not conduct PSIs on misdemeanors and base sentences strictly on past criminal records. As the probation officer, she does have the option of asking for an extended period to complete a PSI if she has reasonable belief that there may be more to the case than a record check will uncover. She has done that twice that she could recall.

During this discussion, we invited the adult probation unit supervisor into the conversation about the adequacy of the PSIs. David had been at the agency a lot longer than Sharon and remembered that they had developed the presentence investigation form in the early 1970s. They had not changed it since then, except for a few questions. We all agreed that a meeting with the entire probation staff would have to be the first step in thinking about revamping the PSI form. David agreed to set that meeting up and we all went home for the day.

The next morning I returned to my office at the DAIP and reported on the PSI, the sentencing, and the meeting afterwards. Our agency began to rethink its advocacy role. Three co-workers, Coral McDonnell, Nancy Helgeson, and Graham Bames, worked with me in meeting with probation officers to make changes to the PSI form. They, too, started to go on police ride-alongs and observe dispatchers and probation officers. We also contacted the advocates at the shelter and asked them to work with us on this project. Thus the stage was set for the development of a "safety audit" of the Duluth court system.

This was not the first PSI I had ever observed, but in the past I had not paid attention to the role that texts-in this case the PSI form-play in directing the work, and the decisions, of the probation officer. However, this process of thinking about work settings, watching people do their work, and thinking about how texts influence that work led me to see a whole range of new possibilities for institutional advocacy and change.

The Story of Changing the Misdemeanor PSI Form: Stage I

We incorporated the objective of changing the PSI process into a project we were working on 
with the Centers for Disease Control. ${ }^{48}$ We worked on three probation forms-the supervised release interview, the felony and gross misdemeanor PSI, and the misdemeanor PSI. All of us learned more about micromanagement issues and how they have defined and standardized the actions of probation officers.

The supervisor of the adult misdemeanor unit of probation and I structured a format for a meeting held in June of 1995 with all of the probation officers, three DAIP staff, and two shelter staff. During the first several meetings, probation officers discussed their cases from the perspective of their respective work settings. Together we talked about actions or behaviors of an offender that would make any of us consider him dangerous to his partner or to anyone else.

We also reviewed signs probation officers might notice during a PSI that would suggest that a particular offender was going to be difficult to manage on probation. Would this influence their recommendations to the judges? Collectively we were trying to identify criteria that could predict whether an individual victim would be safe from an individual offender. What measures would a probation officer then recommend to deter that offender from further use of violence or coercion?

Probation officers said that they placed a great deal of weight on the nature of the offense and the degree to which a defendant took responsibility for what had happened. For example, one probation officer offered this observation:

If a defendant engages in some kind of bizarre or sadistic behavior, like maybe the killing of an animal, or torturing some kind of pet, or forcing the woman to engage in some kind of humiliating act, or threatening to kill her family members, or something like that, then I start to have a heightened sense of fear that a victim is going to get seriously hurt.

A second probation officer said that she noticed if the victim was too dependent on the defendant, "like if she is a chronic alcoholic and needs him for her booze, or if she has small children and needs him to help, or if she is just desperate to get him out of jail or trying to get charges dropped." She saw these individuals as women who might be less able to use the system

\footnotetext{
${ }^{4}$ In 1994, the DAIP received a five-year, $\$ 1.5$ million grant from the U.S. Centers for Disease Control and Injury Prevention to test an enhancement of the coordinated community response in Duluth.
} 
for help. She didn't see these things as signs that the woman was at fault but that she was more vulnerable to his violence.

A third probation officer said that in cases where he had a long history with an offender and knew the pattern of abuse he felt more able to offer the court some kind of useful information on the likelihood of a new offense.

Advocates from the shelter and DAIP staff present at these meetings added many of their own observations about what alerts any of us to the possibility of escalating violence.

We all noted at the end of the second meeting that few of the issues that we had discussed were addressed on the PSI form that probation officers used in domestic assault cases. We generally agreed that the generic misdemeanor PSI form did not allow probation officers to account for the special nature of such cases, particularly regarding victim safety. After some discussion in which the DAIP staff argued for changing the form completely, we agreed that we would spend the next meeting designing a supplement to the existing form. Two of us from the DAIP volunteered to use the information that we had gathered during these two preliminary meetings to outline a supplement before the next session. We also volunteered to bring the new criteria before a group of formerly battered women who had used the court system. ${ }^{49}$ We could obtain ideas from them as to the kinds of indicators that they thought would help a probation officer know whether an abuser would be likely to increase the severity or frequency of his violence.

During the same period, the DAIP was holding regular meetings with researchers at the University of Minnesota-Duluth to develop what we called a "high-risk checklist." This list was supposed to help any practitioner, whether a probation officer, therapist, or police officer, look for indicators that would increase the risk for a victim.

Using Jacquelyn Campbell's book Assessing Dangerousness: Violence by Sexual Offenders, Batterers, and Child Abusers (1995), we developed a checklist of about seventeen items.

\footnotetext{
${ }^{49}$ Forming a special committee of women who have been battered to work on a policy or procedural change has been common practice for the DAIP.
} 
Advocates and battered women from our advisory committee added another nine items, producing the following checklist.

\section{Assessing Dangerousness List}

1. Has the abuser ever injured the victim so badly she needed medical attention?

2. Does the abuser seem preoccupied or obsessed with the victim (following, monitoring her whereabouts, stalking, very jealous, etc.)?

3. Does the abuser have ready access to a gun?

4. Have the abuser's assaults become more violent, brutal and/or dangerous?

5. Has the abuser ever choked the victim?

6. Has the abuser ever injured or killed a pet?

7. Does the victim believe the abuser may seriously injure or kill her?

8. Is the victim extremely protective of the abuser (trying to change or withdraw statement to police, reduce bail, charges, etc.)?

9. Has the victim separated or tried to separate from the abuser in the past 12 months?

10. Does the abuser drink excessively/have an alcohol problem?

11. Does the abuser use street drugs (speed, cocaine, steroids, crack, etc.)?

12. Has the abuser ever been to alcohol/drug treatment?

13. Has the victim sought outside help (OFP, police, shelter, counseling) during the past 12 months?

14. Has the abuser ever threatened to kill the victim?

15. Was the abuser abused as a child by a family member?

16. Did the abuser witness the physical abuse of his mother?

17. Does the victim seem isolated from sources of help (car, phone, family, friends, etc.)?

18. Has the victim ever been assaulted by this abuser while pregnant?

19. Has abuser ever threatened or attempted to commit suicide?

20. Has the abuse included pressured or forced sex?

21. Has the abuser used a weapon against the victim or threatened to use one?

22. Does the abuser lack remorse or sadness about the incident?

23. Does the abuser commit nonviolent crimes?

24. Does the abuser have a history of violence to others (non family members)? 
25. Has the abuser experienced any unusual high stress in the past 12 months (loss of job, death, financial crisis, etc.)?

26. Is the abuser assaulting the victim more frequently?

As we started to look at the use of such a checklist in many different settings within the legal and human service systems, we became increasing uncomfortable about the direction we were taking and, in fact, promoting. We began to recognize that practitioners would inevitably use such a list to assign points to cases to decide how dangerous a situation was. If, for example, one case had 6 risk factors and another 11 , then the practitioner would have to assume that the case with eleven factors was more dangerous than the case with 6 . University researchers suggested that we consider weighting some factors over others and use our research to test the checklist.

One woman on our advisory committee, Denise, presented the paradigmatic illustration of what was wrong with this kind of quantitative check list. If she had filled out a risk factor questionnaire before her husband's attempt to kill her, her case would have been considered a low-risk situation. He had been sexually abusive, intimidating, and cruel for ten years, but never physically violent to her or to their children. He had not been under any unusual stress, he had no weapons in the house, had never choked her, and had he never threatened to kill her.

Denise had decided to leave him. She also sensed that he knew about her plan. One day when she returned home from work, he demanded that she go out and clean the garage. She refused several times but he became extremely agitated. To keep him from getting any more upset, she went out to the garage. He had beaten her dog to death with a two-by-four and strung it up from the rafters. It was a warning.

He had never beaten her. He had never hit her or kicked her, or even restrained her from leaving. About a month after she left him, as she got off the bus coming home from work, he grabbed her, threw her to the sidewalk, choked her, and slashed her face with a razor blade, leaving her for dead. Denise knew well before she left her husband that he was dangerous and that her leaving could result in violence-not because of risk factor points on some scale assigned to her "case," but because of her daily life with him. 
Denise's story led the DAIP to backtrack on the development of any kind of "dangerousness scale" in meetings with the university research team. Unsure of our arguments and lacking the proper academic credentials to argue our case "scientifically," we eventually organized a conference call among the DAIP staff, the university researchers, and several activist researchers. ${ }^{50}$ We explained our dilemma and differences of opinion and asked for their ideas. The outside researchers all agreed that we were entering dangerous territory. The complex twists and turns associated with abusive behavior defy prediction based on a formula; a quantifiable profile of a batterer does not exist. In the end we realized that we were creating an instrument that would not be any different from the PSI form we were trying to revamp: both excluded from consideration the perceptions and lived experience of the woman.

The whole process illustrated for us how easily activists can be drawn into institutional ways of ruling. ${ }^{51}$ It is a trap that makes many activists and feminist theorists leery of these types of reform efforts (Currie, 1990; Dobash \& Dobash, 1992; Pateman, 1987; Schechter, 1982; Smart, 1989; G. A. Walker, 1990). It also points out the vulnerability of community-based advocacy groups to local institutions such as the university. Because of our own reputation in the area we had access to many of the nationally recognized leaders in the field. We were able to call them and ask for a conference phone call. Many local programs would not have had access to these experts and would be left to argue with their local university staff as non-professionals, or at least as non-academics.

The DAIP and advocates eventually decided to put an end to the risk factor list as a possible scale

\footnotetext{
${ }^{50}$ We called Jackie Campbell, author of Assessing Dangerousness: Violence by Sexual Offenders, Batterers, and Child Abusers (1995); Susan Schechter, author of Women and Male Violence: Visions and Struggles of the Battered Women's Movement (1982); Beth Richie, author of Compelled to Crime (1995); Ed Gondolf, author of Man Against Women: What Every Woman Should Know About Violent Men (1989); attomey Loretta Frederick; and victim advocate Eileen Hudon. All of them supported our decision to give up on the scale idea.

${ }^{\text {s' }}$ Even though I had been working on my own research at this time, I was having problems fully articulating why I was so wary of the move towards developing scales on dangerousness. Community-based agencies like ours, which receive federal money to develop programs, are often obligated to work with local colleges or universities to evaluate these programs. The role of the university in these projects has been expanding over the past few years. In our case, locating the research in the School of Medicine proved to be a mistake because of the faculty's uncritical acceptance of the research methods of the physical sciences. Eventually we were able to move this research into the School of Social Work, where we gained a more receptive audience for our questions about the use of scales and risk factors.
} 
to predict dangerousness. Most of the probation officers agreed. They already knew about the arbitrariness of scales and tests. By either law or policy, they are forced to use such measures in determining, for example, who is an alcoholic and who is not, whom to release from custody and whom to hold, which drunk drivers need prison sentences and which do not.

Sentencing is not simply about punishment; it is used to punish, to establish restitution, to put conditions on the defendant that will protect the victim from more harm, to offer opportunities for rehabilitation, and to enforce community norms. Presentence investigation interviews with offenders are used to create a profile of the offender. That profile is based on his relationship to the criminal justice system. We wanted to create a PSI form that would make the safety of the woman a central concern to the sentencing of the assailant. We were trying to build into the structure an authorized and institutionally sanctioned method of making women's experience of violence count.

We spent many hours discussing specific domestic assault-related cases, deterrence theories, Minnesota law, and the practical realities of sentences judges are willing or politically disposed to mete out.

We agreed on seven areas that probation officers should make relevant to the process:

(1) violence and harm used by the offender in the incident for which he had been found guilty;

(2) the pattern of abuse;

(3) victim's perception of the violence;

(4) the defendant's attitudes about his violence, his partner, his need to change his behavior, and his level of danger to his partner and others;

(5) the defendant's social history;

(6) the defendant's history of convictions, police contact, and orders for protection;

(7) the involvement of children in the abuse.

The supplement we developed follows (Figure 12). 
FIGURE 12: PROBATION REFERRAL SHEET

DOMESTIC RELATED OFFENSE INFORMATION AND REFERRAL SHEET

$\square$ Misdemeanor PSI $\square$ Gross Misdemeanor PSI $\square$ Felony PSI

Name:

SOURCES OF INFORMATION (Check all that you were able to use)

Collateral Information

$\square$ Police report

$\square$ OFP history

$\square$ Watch report

पDAIP history

]Interview with offender

\section{SEVEN POINTS TO CONSIDER}

1. Level of violence and/or intimidation of this incident

Single blow or minor injury

Multiple blows, minor injury

Multiple blows, significant bruising

Multiple blows and severe abrasions/injury

Significant pain

[] Bodily impairment

$\square$ Fracture

Comments: $\square$ Required medical attention

$\square$ Caused extreme fear

$\square$ Terroristic threats

$\square$ Threatened w/ weapon

$\square$ Weapon used during incident

\section{Is there information to suggest that the following occurred? Check all that apply}

2. Past violence/pattern of abuse-physical, sexual, intimidation Information for $2 \& 3$ can be gathered from Women's Coalition form, police report, and/or interview with victim.

Offender has seriously injured the victim (needed medical attention).

- Offender's assaults become more violent, brutal and/or dangerous.

- Offender choked the victim.

- Offender has injured or killed a pet.

- Offender has threatened to kill the victim.

- Abuse has included sexual coercion or attacks.

- Offender used a weapon against the victim or threatened to use one.

- Offender is assaulting the victim more frequently.

Offender has attempted to intimidate the victim. How?

Describe the most severe violence victim has experienced from this partner.

Comments:

3. Victim perception-Isolation, victim attempting to separate

- Victim believes the offender may seriously injure or kill her.

- Victim appears extremely protective of the offender (trying to reduce bail, charges, etc.).

- Victim has separated or tried to separate from the offender in the past 12 months.

- Victim has sought outside help (OFP, police, shelter, counseling) during the past 12 months.

- Victim seems isolated from sources of help (car, phone, family, friends, etc.).

Comments: 


\section{Offender attitude}

Offender lacks remorse about the incident.

- Offender denies responsibility for behavior.

- Offender seems preoccupied or obsessed with the victim (following, monitoring whereabouts, very jealous, etc.). There is information to suggest that offender is stalking the victim.

Offender blames victim for the violence.

Comments:

5. Offender social history (If checked, comment below)

Offender drinks excessively/has an alcohol problem.

- Offender uses street drugs (speed, cocaine, steroids, crack, etc.).

- Offender has been to alcohol/drug treatment.

- Offender has had psychiatric treatment in the past.

- Offender was abused as a child or witnessed the physical abuse of his mother.

- Offender seems seriously depressed or has threatened to commit suicide.

- Offender has had homicidal thoughts.

- Offender has committed non violent crimes.

- Offender has been exposed to institutional violence:

- Offender has a history of violence to others (non family members).

- Offender has experienced unusually high stress in the past 12 months (loss of job, loss of children, death, financial crisis, etc.).

Comments:

6. Conviction/Arrest/OFP Record - (violent acts and domestic related)

7. Impact on children - Safety needs of children during visitation, abuse of children

- Were children present at this incident ?

- Were children involved in any way in the incident?

- Have children been abused by offender?

- Has offender ever attempted or threatened to abduct children?

- Are children afraid of the offender?

Comments: 
Judges and others in the criminal justice field hold widely divergent philosophies on sentencing.

One judge who reviewed the new PSI form commented,

Sentencing should be a part of setting standards in the community, it should say that a particular behavior is not to be tolerated. Second, it should keep that particular defendant from committing the same or similar offenses. Third-and I don't mean here third in importance-sentencing should protect the public and that especially includes the person who was abused. We have the objective of treating similarly situated cases similarly. I don't think you'll find much argument with what I've just said but you will find much disagreement on what a judge can and should consider when sentencing. I want to fully understand the situation, not just what happened that night. We can only convict based on what happened in that incident. We can't convict someone of assaulting their partner because we believe he's a batterer. The state has to prove beyond a reasonable doubt that this incident did occur. But that's not the standard in sentencing. A judge has a wide latitude in sentencing zero to ninety days in jail, up to two years on probation, that is all there in order to allow the judge to take measures that will address the situation. (Interview, January 15, 1996)

The new PSI form, although fraught with its own problems of a generalizing text, is meant to shift the probation officer from presenting the court with what is essentially an offender's citizenship report to presenting a picture of his offense in the context of his use of violence in this or past relationships. It informs the court about the defendant as a batterer and, to a lesser extent, as a potential flight risk or supervision problem. The group could not reach a consensus about the final form, but we agreed that this form provided better and more thorough information to the court than the old one. We also agreed that during the sentencing process the new PSI form could alert the probation officer, the court, and in some cases, the victim, to safety issues. In essence, what we were doing was not eliminating documentary practices or eliminating the textually mediated characteristic of the legal system but claiming that feature for the benefit of battered women. We were doing so by incorporating into those documentary practices attention to the pattern of coercive, intimidating, and violent behaviors and therefore attention to the needs for taking protective measures on behalf of victims.

The old PSI ignored the fact that first-time domestic-related misdemeanors are not all the same. A woman has usually been assaulted many times before her abuser is convicted of an offense. Some misdemeanants convicted for the first time have continuously engaged in a pattern of 
intimidation, violence, and coercion and are extremely dangerous. Others are not.

After completing the work on the PSI form, the group continued to meet to develop a sentencing matrix for domestic-related misdemeanor offenses. By reviewing two or three domestic-related cases that each probation officer had on her or his case load, we divided the sentencing options into four categories. The first category includes those cases in which the offender had no apparent sustained pattern of intimidation, violence, or coercion. Many battered women who illegally fight back fit into this category. Men or women who have assaulted their partners but have not engaged in a pattern of abuse fit here also. The most severe category involves cases where the probation officer found a pattern of severe abuse, stalking behavior, and little interest from the abuser in changing. For the first category, the probation officers recommend no jail time other than what the offender has already served following the arrest, and rehabilitation specific to the case. For the fourth category, they recommend between 60 and 90 days in jail, with 2 years of probation if they do not serve the entire jail time, and increased monitoring of the offender. ${ }^{52}$ In all categories the offender is prohibited from having contact with the victim if that is the victim's request.

Figure 13 is the sentencing matrix the group developed. It is designed to account for the particulars of the case specifically as they relate to the pattern of abuse the woman is experiencing. It is an attempt to create a regulatory text that accounts for the women's experience of violence and focuses on the need to enact safety measures commensurate with the level of violence an abuser is willing to use.

\footnotetext{
${ }^{32} \mathrm{~A}$ person cannot be put on probation if he has served the maximum jail sentence for a crime; probation is in lieu of more jail time.
} 


\section{Category one}

The offender commits an offense against the victim but there is no evidence to suggest the offender is battering the victim. The offender has no history of battering.

This category may include offenders who commit an act uncharacteristic of their typical behavior. It may also include viclims of ballering who use illegal violence or aclivities to control or stop violence used agains! them.

Considerations: If the offender in this case is experiencing ongoing battering by the person assaulted, the probalion officer considers safety measures for both parties. Specialized programming is recommended, and the probation officer would not consider execuled jail time unless the assault is severe.

\section{Category two}

\section{Category three}

Category four
The offender engages in battering behavior with this victim, but there is no indication that the batlering is escalating in severity or frequency, or that this offender has battered another person.

This category may include ballerers who have a hislory of using low levels of violence and activilies which threalen or intimidate the victim. The offender may not intend to place the viclim in fear of serlous bodily harm.

Consideratlons: The recommendation focuses on victim safety and rehabilitation programming rather than sanclions.
The offender has established a clear pattern of battering with this or past viclims. The PSI indicales the battering

will likely continue and possibly escalate in severily and frequency.

This category may include balterers whose history includes: mulliple domestic violence-related contacts with the police: demonstraled harassing behavior" toward the victim; violation of an OFP; repealed threals or assaulls against this or other victims. The victim may be in fear of serious bodily harm.

Considerations: Victim safety recommendations are combined with more sanclion-oriented senlencing, such as the maximum probationary period, some executed jail lime, and programming.
The offender's PSI demonstrates that the heightened, obsessive and/or unrelenting nature of the battering poses a high risk of serlous harm to this or olher victims.

\section{Thls category Includes offenders with} backgrounds similar to calegory three offenders but may also include: stalking behavior," threals to seriously harm or kill threats or use of weapons; injuries that require medical allention.

Considerations: The most aggressive victim safety measures possible including working with child protection on children's safoly. A substantial jail term and long-term probation may be combined with programming if amenable."

*terminology next page

Incarceration or other correctlonal programming"

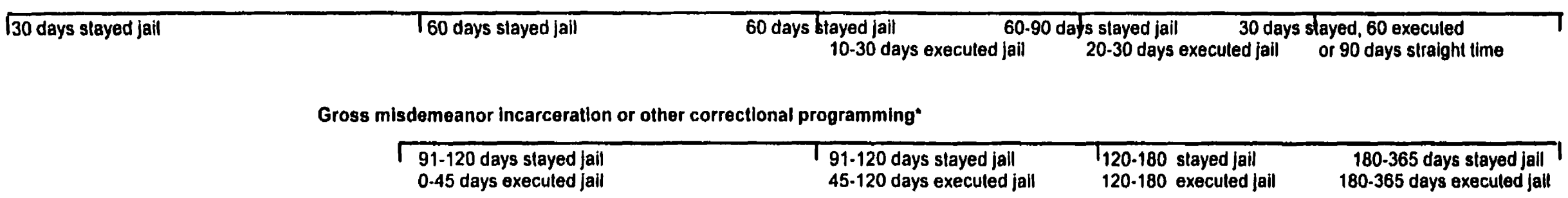

Probation duration (Gross misdemeanor convictions routinely receive 2 years probation)

\begin{tabular}{ll|ll}
\hline one year one year two years years & two
\end{tabular}

Artowhead Regional Corrections, Duluth, MN 
Finally, we developed a form that probation would use when recording their recommendations in order to focus attention of both probation officers and judges on the three functions of sentencing: offender accountability (punishment), rehabilitation, and victim safety. It also serves as a referral form to the DAIP. That form appears as Appendix I.

The Story of Changing the Misdemeanor PSI Form: Stage II The work setting of the probation officer was not designed for the production of this new PSI form. The next stage of change would have to focus on making new information institutionally accessible to the probation officers. The revised PSI form requires a significant amount of information from the abused woman.

This was a twofold problem. First, the specialized labor practices discussed earlier involved three practitioners and an advocate talking to the woman before the PSI is conducted. The dispatcher, the responding police officer, and the on-call advocate all talk to the woman within a few hours of a call to 911 . Usually, the supervised release agent talks to her a day or so after the arrest. No routine was set up through which to communicate the relevant information from these contacts to the probation officer. A small fraction of what a woman reports to any of those interveners is made available to the probation officer.

The second part of the problem centered on the type of information that practitioners were eliciting and recording. The dispatcher elicits and records information about the situation that the officers will be encountering. As shown earlier, additional information given to the dispatcher about the context of the violence is not routinely recorded. The officers are looking for the elements of a crime and the basis for making a probable cause arrest; most of what the woman has to say about the totality of her experience of the abuse is either not elicited or not recorded. Yet this is exactly what the probation officer needs to know to recommend a sentence that makes the safety of the victim a central concern. The on-call shelter advocate who makes a home or hospital visit immediately following an arrest focuses on the assistance that the shelter can offer. This advocate could also help the woman communicate her situation and need for safety measures to the court. 
To incorporate the perceptions of battered women in a way that expands the practitioner's orientation from the task of accomplishing a narrow administrative case processing function to that of enhancing the protection of the victim required a new set of negotiations with department supervisors and practitioners in the system.

The director of the probation department could not just call up the police chief and say, "Scott, we've made some changes to the PSI, and I'm going to need you to retrain your officers on writing domestic assault reports so they include information my people need to do PSIs." Even to the extent that this informal network of power brokers exists, community-based advocacy groups are rarely able to tap into it when they organize for change. Coral McDonnell, Nancy Helgeson, and I began by meeting with the supervisor of the patrol division. We showed him the new PSI form and explained that it would require the development of a similar specialized police reporting form for domestic abuse calls. He immediately rejected a special report form. We then went up the chain of command to the police chief, who said, "You can write up a cheat sheet if you want. You can train officers on its use, but no specialized arrest forms." ${ }^{\text {"s }}$

We had obviously struck a bureaucratic nerve. Police officers were inundated with specialized reporting requirements and often had as many as a dozen specialized report forms to carry on a shift. The Duluth Police Department had just spent the past year trying to reduce the number of these forms and was not ready to make an exception to its own rule. We gave up on a specialized form and instead took up the notion of writing an outline for officers to follow when dictating a report.

We enlisted the help of the city's chief prosecutor in designing a new reporting format and in training officers on its use. She was interested in working with us to develop the "cheat sheet" that the chief of police had suggested. She wanted the police reports to routinely include specific information that would enhance her ability to get convictions. Several police officers, the city attorney, and two legal advocates worked on the design of the "cheat sheet," which we then had

\footnotetext{
${ }^{53}$ Our relationship with the police has been quite cooperative, but we don't always get what we want. We've discovered that a narrative rather than a form actually provides much better information on the case and once trained on using the narrative format, officers provide a more complete picture of the safety issues of the victim.
} 
made into small laminated cards that would fit into an officer's shirt pocket. Figure 14 shows the two sides of the card.

\section{FIGURE 14: REPORT WRITING CHECKLIST}

\section{Domestic Abuse}

\section{Arrest/lncident}

\section{Report Writing Checklist}

Duluth Police Department

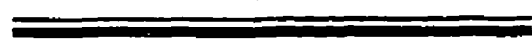

Times (incident, arrival, statement)

1. Parties present

2. Emotional state (describe) Victim/ Suspect

3. Injury to victim

4. Injury to suspect

5. Describe scene

6. Relationship of victim/suspect

7. State if children present, not present,

witnessed, or involved

Describe involvement

8. Pictures taken

9. Evidence collected

11. Medical attention (where?)

12. Note when any of the following are present: OFP. probation, victim/ suspect intoxicated

13. List where suspect lived in past 7 years

14. Witnesses' names, addresses. phones, workplaces

15. How can Detective Bureau or others reach victim during next 24 hours?

Name, address. phone of person who will always know how to reach victim

16. Notes for narrative: victim statement, suspect statement. witness statement, probable cause for each arrested party. Who initiated? Self-defense?

continued on other side
Risk Factors: To be used by court for conditions of release, PSIs, advocacy needs for victims

Please note those observed or those which appear to exist.

1. Guns or other weapons in home

2. Suspect has access to or carries weapons

3. Suspect abuses alcoholdrugs

4. Suspect under high stress recently

5. Suspect has threatened or attempted suicide

6. Threats to kill or severely harm victim/others

7. Victim believes suspect may seriously injure or kill her

8. Suspect obsessed with victim, stalking

9. Victim has called police before

10. Recent separation, OFP, divorce in past 6 months

\section{MDT Temporary Report}

1. Name, phone. address of victim

2. Alleged offenses summary

3. Who to follow up: a) Detective Bureau; b) Victim advocate; c) Child protection worker, d) Prosecutor

4. Officers' action taken

\section{Remember to re-code if necessay}

Sample of a two-sided laminated card for police officers use when dictating domestic violence related reports.

Developed by Duluth City Attorney's Office. Duluth Police Department. and Minnesota Program Development, Inc. 9/95 
We designed a new 3-hour police training focused on writing the arrest or investigation report using the card as an outline. Simultaneously, we worked with the police to get daily copies of the dispatch record. The chief prosecutor conducted a series of trainings for all patrol and supervisory officers over a 2-month period. The training focused on the importance of the police report in establishing the basis of the prosecutor's case and showed officers how the risk factors and questions about children would be used to alert victim advocates and child protection workers to cases where there appeared to be a high level of danger. It also provided supervised release agents and probation officers making sentencing recommendations with a better picture of the level of intervention necessary to deter a particular offender and protect a particular victim.

Following that training Nancy ${ }^{54}$ and I attended shift changes ${ }^{55}$ in the squad room for 4 days and passed out the new report guides. We explained that Nancy would be picking up reports on a daily basis to make sure that the information they contained would be immediately routed to other intervening parties: probation officers, shelter advocates, prosecutors, civil court judges. We told officers that to gain a high degree of consistency in the use of the new format, Nancy would read each report, send the supervisor of the patrol unit a checklist on reports produced in that unit, and point out the missing information. On the following page is a copy of the form Nancy used to report to a unit supervisor (Figure 15).

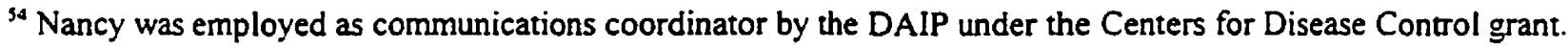

ss A shift change is a 15-minute briefing of officers beginning a new shift. Usually the unit's sergeant or lieutenant conducts the briefing.
} 
FIGURE 15: DOMESTIC ASSAULT REPORT FEEDBACK FORM

DOMESTIC ASSAULT REPORT FEEDBACK

\begin{tabular}{|l|l|l|l|}
\hline ICR \# & Incident Location: & Date: & Officers: \\
\hline & & Group A B C D (Circle) \\
\cline { 2 - 3 }
\end{tabular}

\begin{tabular}{|c|c|c|c|c|c|c|c|}
\hline $\begin{array}{l}\text { Are following isems covered in } \\
\text { report? }\end{array}$ & Yes & No & $\begin{array}{l}\text { Comment } \\
\text { (see reverse) }\end{array}$ & $\begin{array}{l}\text { Are following items covered in } \\
\text { report? }\end{array}$ & Yes & No & $\begin{array}{l}\text { Comment } \\
\text { (see reverse) }\end{array}$ \\
\hline 1. Times & & & & $\begin{array}{l}\text { 11. Medical Antention } \\
\text { Facility noted }\end{array}$ & & & \\
\hline 2. Parties present & & & & 12. Background info & & & \\
\hline $\begin{array}{l}\text { 3. Emotional state } \\
\text { Victim - Suspect }\end{array}$ & & & & $\begin{array}{l}\text { 13. - Witnesses } \\
\text {-Person able to reach } \\
\text {-Victim location } 24 \mathrm{hrs}\end{array}$ & & & \\
\hline 4. Injury to victim & & & & 14. Narrative notes & & & \\
\hline 5. Injury to suspect & & & & Victim statement & & & \\
\hline 6. Scene & & & & Suspect statement & & & \\
\hline 7. Relationship & & & & Wimess statement & & & \\
\hline 8. Children & & & & Probable cause elements & & & \\
\hline Children involvement & & & & $\begin{array}{l}\text { Where both parties lived } \\
\text { during the last seven years. }\end{array}$ & & & \\
\hline 9. Pictures taken & & & & 15. Risk Factor notes & & & \\
\hline 10. Evidence collected & & & & & & & \\
\hline
\end{tabular}

These checklists became known as the "DAIP report cards" and were bitterly resented. Officers complained that non-police personnel were being put in the role of judging their work, yet no such reciprocal arrangement existed between police and the shelter or the DAIP. We decided to end the hated practice of issuing "report cards" and instead began to meet with unit supervisors to review the reports and ask them to notify officers about those which were incomplete. ${ }^{56}$

Officers followed the new format quite closely with the exception of the questions regarding the overall pattern of abuse. This was referred to on the laminated card as the risk factors. Fewer than half of the officers asked and recorded information about the risk factors. Below are excerpts from an investigative report in which the officer did respond to the items on the risk

${ }^{56}$ We had anticipated that it would take 3 to 6 months to reach a 90 to $95 \%$ compliance rate with the format. 
factor list. I have underlined the information acquired as a direct result of his questions. The excerpts show how adding the institutional objective of tending to victim safety contextualizes the violence. It provides the multiple readers with a very different version of what is going on and therefore elicits a very different sort of response.

Date/Time of Occurrence $03 / 18 / 950300 \mathrm{hrs}$

Date/Time Reported 03/18/95 1226 hrs

SYNOPSIS:

Officer was dispatched to a report of a domestic assault at the above location. Officer spoke with the complainant who said she had been assaulted approximately 10 hours earlier. No visible signs of assault were evident to officer. Written statement to be completed by victim. Victim advised to obtain order for protection and suggested that she stay at women's shelter. Victim said she would complete written statements and bring them into the Duluth Police Department. Victim declined to go to women's shelter and said she would seek an order for protection. A warrant request is to be made on suspect.

DETAIIS :

On 03/18/95 at approximately 1227 hours... Upon arrival. .

Johnson said she. .

Johnson said when she and Doe . .

Johnson said Doe and her began to argue. .

I observed Johnson's neck and chin area where she said she was experiencing some swelling and redness, but I could not find any signs of abuse. There was no swelling or redness at the time I viewed Johnson's face and neck. Doe said her neck muscles were very sore on the back of her neck and were sore to the touch. In 
looking around the room, I observed there was clothing scattered across the floor, and Johnson said that was from when Doe had "gone crazy." I asked Johnson what type of relationship she had with Doe, and she said they had been dating for approximately seven months and that they have been living together for the past three months. They do not have any children, and they have never been married to each other.

No pictures were taken of Johnson nor was there any evidence to be collected on the scene. Johnson did not say that she needed to obtain any medical help at the time I spoke with her.

Johnson mentioned that Doe was very intoxicated at the time the assault took place and that Doe had begun to drink a lot more than he ever had before. Johnson said Doe does not use any other drugs but only drinks. Johnson said Doe does not have any guns at the residence where they are currently living, but Doe is a very accomplished marksman as he was in the military in the Special Forces Unit during Vietnam. Johnson said Doe keeps track of her every movement, making phone calls, following her around, and making sure he always knows where she is. Johnson said this is the first time Doe has become violent with her but said Doe's ex-wife has been assaulted by Doe at least two times in which the police were called.

Johnson said Doe has talked to Johnson about committing suicide and has told her that if she ever leaves him, he would jump off a pier into the bay. Johnson also said that the present time, it seems that they are in somewhat of a financial bind largely due to excessive drinking by Doe. Johnson does feel that Doe may seriously injure or kill her because of the threats he has made to her. Johnson has never called the police prior to this incident and has never had an order for protection against Doe. 
Johnson was asked if there was a person who is always able to reach her, and she said her sister-in-law, Jane Black, whe lives on central Entrance in Duluth and who works at Penny's, can usually reach Johnson should she need to be contacted in case of an emergency. Johnson said she would stay at her residence this afternoon unless further problems start up. I asked Johnson where both her and Doe have Iived for the past seven years. Johnson said Doe has Iived in Placketon, South Dakota, for the past seven years, and Johnson has been a resident of the City of Duluth for the past ten years.

Johnson was given a voluntary written statement form. .

Doe was unavailable for interview as he was not at the residence at the time of this complaint nor was he at work at Boe's Repair on First Street. A warrant request for fifth degree domestic assault is requested based on the aforementioned complaint, pending return of written statements by complainant.

This report illustrates how such a process can assist in contextualizing the violence against a woman. This case is no longer a misdemeanor involving an offender who threw his partner down and rubbed her face into the carpet, leaving no signs of injury, but an account of a potentially very dangerous situation. This contextualized account will be made institutionally accessible to several key practitioners such as advocates, supervised release agents, probation officers, and sentencing judges when making decisions about safety measures. When I asked several patrol officers about the resistance to incorporating the risk factors into their reports I found their resistance to using the risk factors was not so much a lack of concern for victim safety as it was a function of how police are organized into the reader-writer relationship, in this case the police as writer and prosecutor as reader.

I'm investigating a crime, gathering evidence for a prosecution. I'm not doing an evaluation of the relationship between these two people. (Interview, July 21, 1995) 
I can't say I'm resistant. I'm just not thinking about that when I'm interviewing somebody. It can be pretty chaotic and for me to all of a sudden start asking a bunch of questions not related to what's going on right then and there can put a lot of people off. I want to get what I can for the case and to throw in a bunch of irrelevant stuff just makes the whole situation more precarious. (Interview, July 21, 1995)

These officers have been trained and have operated for years as links to the prosecution of the case; to now change that relationship so that officers see themselves as coordinated with broader intervention goals, including centralizing victim safety as an institutional objective, is not a simple task.

While we were working through this change with the police, we were meeting with shelter advocates to review their process of making visits to women following arrests. The purpose of these visits was to help women do safety planning. On home visits advocates spent from 30 minutes to several hours talking with women about their options: Does she want to come to the sheiter before his release? Does she want to file for a protection order now? He can be served while in jail. Does she know about the services available in the community? Does she need medical attention? Are her children in danger? Does she want photographs taken of her injuries for documentation? Does she understand the criminal court process that will follow this arrest?

We asked advocates to re-enact a few visits and talked about the connection between the visit and the decisions that would be made in court affecting her safety. Shelter legal advocates agreed that the court process should be better explained to the woman. They would also ask her about the dangerousness of the abuser and what court measures she would need to feel protected from recurrent abuse. The on-call advocates would fill out a specialized form and fax it to the courthouse before arraignment court each morning. The following form (Figure 16) shows the information added to the advocate's report of the visit. 
The following questions are designed to help assess the dangerousness of the situation. Answering these questions can help both you and the court decide what safety measures should be put in place to help protect you and will be helpful in providing rehabilitation for the offender.

Can you describe past violence and/or injuries (worst incident, type of injuries, frequency):

During the course of your relationship, has your partner (referring to the person who has just been arrested):

\section{yes no}

1 .

2.

3.

4.

5.

6.

7.

8.

9.

10.

11.

12.

13. become increasingly more violent, brutal, and/or dangerous to you?

caused injuries to you which required medical attention?

choked you?

injured or killed a pet?

threatened to kill you?

forced sex or used sexual coercion?

used a weapon against you or threatened to use one?

seemed preoccupied or obsessed with you (following, or stalking, very jealous, etc.)?

increased the frequency of assaults upon you?

Do you believe that $\mathrm{s} / \mathrm{he}$ may critically injure or kill you?

Have you separated or tried to separate from your partner in the past 12 months?

Have you sought outside help (OFP, police, shelter, counseling) during the past 12 months?

Do you feel isolated from sources of help (car, phone, family, friends, etc.)?

Please elaborate on 'yes' answers:

Is there other information you would like the court to know about the danger you may be in (an event, a specific threat, a feeling you may have)?

yes no

Would you like the court to order the assailant to have limited or no contact with you?

Would you be interested in a protection order?

Are you interested in attending education/support groups?

Would you like to receive our monthly newsletter and group calendar?

This information is used to assist us in providing services to you and to evaluate our services. We ask your permission to give this information and photos to other agencies who hold offenders accountable and provide protection for you. Can we share this information with:

Supervised Release Agents/Probation Officers for setting conditions of release from jail and sentencing recommendations

Domestic Abuse Intervention Project (for rehabilitation purposes)

Prosecutors

Signature

Date

arreston.cal $9 / 95$ Form developed by Women's Coalition, Duluth, MN

However, probation officers and other practitioners in the legal system resisted giving women's advocates an authorized voice in the processing of the case. They regarded information that came 
from the shelter as "biased" and "less reliable than a police report." Probation officers were reluctant to use notes prepared by shelter staff or volunteers as the basis of their recommendation to the court. The shelter was, after all, an outsider to the system; their information could not be treated as insider information. Probation officers deemed the advocate intrinsically biased and believed that her information would not necessarily reflect what the woman had said but "what she had been encouraged to say." As one probation officer put it, "... perhaps they would inflate the information to bolster the lady's case." Shelter advocates are neither "objective" nor "professional." To be "professional" meant to put one's personal views aside and operate from within the boundaries of "the profession." We did not argue that the shelter report was objective, but we did argue that it was untrue that professionals in the system were objective and that having an advocacy function did not make advocate information unreliable.

The dilemma of trying to change this institutionally entrenched perception put the sheiter in a double bind. On one hand, none of the shelter staff would want to draw advocates into an institutional case management role. They clearly want to remain outside the system, yet on the other hand, they are committed to creating a process in which the information they provide to the court is considered as credible as information coming from any practitioner within the system.

To resolve this conflict, we set up a training conducted by probation officers for the on-call advocates. We began the session by having probation officers describe their job in making recommendations to the court on conditions of pretrial release and later sentencing. Each advocate then described a home visit she had recently made.

The probation officers and the advocates asked many questions of each other and the training quickly became a dialogue. Advocates expressed a strong reluctance to become involved in trying to get the woman to work with the system on a conviction. One advocate summarized the group's argument: "I don't mind filling out a report or form and faxing it to you if that will help protect the woman. Still, she has to agree to my sending this stuff. If she's not into having him go through the criminal process, I don't want it to be my job to talk her into it" (training session, October 19, 1995). 
This session helped resolve two issues. For the probation officers it clarified the role of advocates and clearly showed that advocates did not consider a conviction a measure of success. We agreed that advocates would explain both the pretrial release procedures and sentencing procedures and ask women if they would be interested in having the advocate fax the information to the probation department. ${ }^{57}$

A repeat offender meant to the court, until now, that he or she had prior convictions. The new approach takes into account that an offender can repeatedly use violence, intimidation, and coercion against a partner, with or without prior convictions. It replaces the exclusively incident-focused approach with one which takes into account the context of the violence, discernable patterns of abuse, and the perceptions of the victim. It is a process that makes the court more accountable to victims of domestic violence.

The final link in the sentencing process proved more difficult to change. Judges were only marginally involved in the development of the new PSI and the sentencing matrix. The chief judge of the district and the assistant chief judge both reviewed and commented on the drafts of the documents. During a discussion between the DAIP and probation on how best to introduce the new procedure to the judges, one probation officer stated,

It'll ruffle some feathers and cause some grumbling, but it's really the professional responsibility of this department to put before the court the best recommendation possible to deal with this offender. We've been missing the boat on domestics and everybody knows it, but will this cause some flack? You bet it will, and our agents will just have to deal with that. They'll have to stand behind their recommendation and the process we used to come up with that recommendation. (Interview, November $8,1996)$

We decided to ask the chief judge to bring the new PSI form and the matrix to the attention of the other judges and have them deal with arguments internally. The chief judge simply sent out a memo with the new PSI form and the matrix attached, stating they would go into effect immediately. The bench did not embrace the changes with enthusiasm but neither did it discard

\footnotetext{
${ }^{57}$ According to Madeline Tjaden, Women's Coalition legal advocate, more than $90 \%$ of the women with whom they work sign the release to fax the information (Interview July 17, 1996).
} 
them.

One probation officer describes her first experience using the new matrix:

Nobody liked what I was doing, not the judge, not the public defender, certainly not the offender. It was hard to go against what I was recommending because I had put it all in the record. This was radically different... I was focusing on different things ... the whole listing of violence and the victim's safety. In the end it's hard to justify not going along with a different kind of sentence because if a problem comes up later I put all that stuff in the transcript. It was very hostile the first few times, I felt like a lamb in the lion's den. (Interview, January 23, 1996)

The process had focused so far on regulatory and administrative texts, but the politics of resistance materialized at the point of execution. I had attributed to probation officers the power to influence sentencing: prosecutors and defense attorneys made deals and then agreed to abide by the recommendation of the probation officer following a PSI. It seems that this was conditional power. It was given because probation officers acted within certain institutionally approved boundaries. The new process which changed those boundaries brought us all into the realm of the legal argument.

Some judges and defense attomeys argued that use of the PSI and matrix produced a process through which they were sentencing an offender for actions that had not been proven in court. Others, however, argued that sentencing should be based on what the court believes will accomplish three goals: deter this offender from committing the same or similar offenses, deter others in the community from committing these offenses, and protect the victim and public. The state leaves the court wide latitude to accomplish these goals in misdemeanor cases, including the use of incarceration for up to 90 days and the use of probation instead of jail for up to 2 years. Indeed, the state legislature recognized the special problems associated with sentencing batterers when it extended the length of time an offender could be placed on probation for a domestic-related misdemeanor from 1 to 2 years.

A shelter advocate summarized the reaction to the matrix: 
The problem is that the judges just assume that a man gets one free beating. That is, one free conviction for beating his wife. I can't think of a man who's been convicted in the past year where this was the first time he ever beat her up or assaulted her. So why do we all start out presuming the sentence should be "go to classes" and "no jail"? Some men don't need to go to jail-arrest and one or two nights in jail is quite powerful-but others do. They are making this woman's life hell and flaunting the fact to her that they can get off. The sentence should be based on how he is using violence against her, not what kind of a guy he seems to be to the judge. (Interview, November 21, 1995)

Judges do not as individuals make the assumption to which this advocate alludes. It is structured with sentencing practices and normalized in daily work routines which once uncovered can be held out for inspection.

\section{Conclusion}

The process I have described, changing a single work setting so that it is designed to account for women's safety, provides an insight into a legal advocacy strategy. By engaging workers in an examination of their own work processes we simultaneously work toward progressive change at the level of practice and attitudes. In this work we are looking for how safety is accounted for in the institutional objectives of processing domestic assault cases. Chapter 9 explains this strategy by laying out the principles of conducting an institutional audit. 


\section{CHAPTER NINE}

SAFETY AUDIT

The courthouse in Duluth is located in the center of the city's business district. The three imposing buildings of the government complex face a courtyard guarded by a twenty-foot statue of a sword-wielding Greek warrior towering over a terraced fountain. As one faces the complex, the federal building is to the left. It houses the FBI, the postal service, several federal courtrooms and magistrates' offices, and the IRS. Directly across from it is city hall, where the police, mayor, city attorney, and city council conduct their business. Between them is the St. Louis County courthouse.

The courthouse ground floor houses many of the county's administrative offices: purchasing, highway maintenance, building maintenance. The first floor is dominated by courtrooms and the offices of those who staff them. Arraignment court, conciliation court, and the court administrator's office are on this floor. It is always busy. One floor up are the county commissioners' offices and board room and the licensing bureau for boats and cars and hunting and fishing. The county's microfilm office and the county auditor's office are also located on this floor. The third floor has more courtrooms, probation, family, and juvenile court judges, and more court administration staff. The cases handled on this floor pertain mostly to family matters, divorce, juveniles, and protection orders. The fourth floor has more courtrooms and judges, and bigger cases get handled here, such as murders and robberies. The only time I've ever been searched was on this floor. The fifth floor offices are occupied by the county attorney's office. The county attorney is considered by many Duluth political observers to be the most powerful political figure in the county.

A man who physically abuses his partner does not usually do so in the courthouse. He does it in his home or in his car or at his neighborhood bar or in his back alley. He uses violence in "his" territory. The courthouse is clearly not his territory. He is not the powerful figure here that he is in his home, yet in many ways the power he holds in his home is akin to the modes of governing, regulating, and managing that constitute the daily activities that occur here. As a man who has beaten his wife enters the courthouse, he breaks the shield between the private and public sphere 
that has dominated legal debate and discourse for two centuries (Olsen, 1983). He enters at a particular historical moment in this debate. The fact that he is entering the building at all is the result of women barging into the debate and altering its terms. The fact that he comes into the building under the escort of a county sheriff is the result of the police department's mandatory arrest policy, which exists because of recent gains in the centuries-old struggle of women to evoke the power of the state in criminalizing violence against women (Dobash \& Dobash, 1992).

Carved into the facade over the main entryway of the courthouse are the words, "The people's laws define usages, ordain rights and duties, secure public safety, defend liberty, teach reverence and obedience, and establish justice." And yet advocates and battered women who pass under these words know from their everyday experiences that the situation is otherwise. George Smith (1990) contends, "The ideology of a politico-administrative regime is ruptured when people know a situation to be otherwise on the basis of their everyday experiences" (p. 632). I have conducted my investigation with an eye towards discovery of how it is that public safety, in other words, the safety of battered women, becomes so marginalized in the criminal court setting. I have used D. E. Smith's notion of an institutional ethnography, which begins at the same place advocacy begins, in the everyday world of battered women. I found in my investigation that what I had previously seen as victim blaming and as sexist attitudes among individual practitioners in a male-dominated institution is not so much a phenomenon of people's attitudes or thought processes. It is more an expression of ideological practices, embedded in textual realities, which extend extralocal relations of ruling into local settings, defining and regulating the everyday life of women who are brought into the legal system as victims of a domestic-related crime.

The totality of the processes that I have discussed in the previous chapters serves to transport the particulars of women's lives into abstracted and generalized forms of case management which are not required to accurately reflect a woman's experience or account for her safety. In the previous chapter I described a rather haphazard process of change that was triggered by the results of research conducted by a single activist graduate student. Conducting a similar but more systematic investigation with a team of practitioners and advocates can become a critical method for local communities to deepen the level of the progressive changes that have been engendered by the legal advocacy work of the battered women's movement. The description of 
change in a single work setting, the presentence investigation, illustrates the complexity of institutional advocacy and the susceptibility of the legal system to certain levels of reform. It also depicts the unevenness of change (Brown, 1992). In this chapter I am summarizing my research by suggesting that legal advocates persuade their local police, probation, and prosecutor's offices to jointly conduct a safety audit (an institutional ethnography) as a method for initiating a systematic investigation of problematic legal processes. This investigation will lead to a blueprint for making changes which centralize victim safety as an institutional objective in the processing of these cases.

A safety audit can be both an investigative and an organizing tool. As an investigative process it will dispel the myth of the objective investigation of crimes and explicate how the ideological processes of ruling are at work in these cases. As an organizing process it can be designed to involve an interdisciplinary team which includes community-based advocates in an effort to facilitate the process of proposing and implementing changes in the legal system. The first objective is to discover how safety is compromised in the legal system. The second objective is to overcome resistance to change. I'll talk about the latter first.

\section{The Audit as an Organizing Tool}

I work in a medium-sized nonprofit organization which is audited yearly. Our organization is a collective so we all share some administrative functions. I am not on the finance committee but like any of us in the organization, I can tell when an audit is coming. About 3 weeks beforehand we start getting notes in our message boxes such as, "You didn't sign your February 1-15 time sheet, please stop by and do so," or, "There is no receipt for your airline ticket to Atlanta in June, where is it?" These messages tell us that the accountant is getting ready to have someone pour over her books, asking a million questions and seeking documentation for the thousands of financial transactions we conduct in a year. Audits may not keep people from embezzling but they do tend to draw everyone's attention to proper financial documentation at least once a year. I am using the concept of an audit in order to evoke that same image and that sense of examining practices. However, I am proposing that unlike a financial audit conducted by an outsider, an institutional audit be conducted by a team both of advocates and of practitioners within the legal system. 
Organizing an interagency audit team has several important advantages over hiring a consultant to conduct an audit for a community. First, it provides an institutionally authorized voice for the concerns of victim advocates by involving them as co-investigators on a team. Much of the resistance to advocacy concerns is linked to activists' status as outsiders. Having an outsider role is important to advocacy efforts, as is evidenced by those groups which have located themselves within the bureaucracy and have then been so reshaped by institutional objectives that they have lost their advocacy voice. As one legal advocate for the Domestic Abuse Project in Minneapolis reported at a statewide advocacy meeting, "I used to explain what the woman needed and wanted to people in the court system. Now, I seem to be mostly explaining what people in the court system need to battered women" (interview, September 11, 1995).

Participating in an audit provides a temporary position for advocates which does not appropriate them into a case-processing role, where co-optation is most likely to occur. As members of the audit team they will not be asked to "bring a victim around" so that she sees the value of helping in a prosecution or filing for a protection order or participating in her assailant's counseling. Much of the work of advocates is finger pointing and confrontation. Their way of doing things is seen as hostile, unprofessional, and negative. An audit approach draws practitioners into an examination of a system that they complain about endlessly with their co-workers yet vigorously defend against attacks from outsiders, such as legal advocates for battered women. It provides a place for advocates and practitioners to work together which can legitimize the advocacy group's voice without making that voice vulnerable to appropriation (G. A. Walker, 1990).

A safety audit creates a victim-focused (woman-focused) frame of reference for court practitioners examining practices regarding these cases. The fragmented work processes and incident-focused features of the criminal justice system create a frame of reference for workers which has little to do with victim safety. The audit will serve to embed within the system safety features which will parallel the generic objectives of criminal case processing. Such an audit will produce concrete changes in routines that will reduce the disjointed approach to case management while orienting each processing stage to an expanded institutional objective of safety. 
If an audit is based on the premise that retaining the woman's experience of violence increases the likelihood of practitioners acting in ways attentive to safety, it will explicate the power and gender aspects of these cases which are now expunged in the generic processing of an assault case. Feminists have long held that if women's lives were talked about and accounted for in how we manage our society, then everything would change. An audit can explicate how women's lived experiences are screened out of the information-gathering process and suggest ways of making such information central to case processing. Depending on how the audit team defines safety measures, there is the opportunity to incorporate changes at the level of daily practice which will raise the consciousness of practitioners to the power dynamics inherent in gendered relations and particularly in gendered social relations marked by violence.

An audit is designed to look at routines, forms, policies, regulating text, and protocols, not individuals. It does not focus on the beliefs or attitudes of individual practitioners and will therefore bypass much of the resistance of individuals to examination. I found most Duluth practitioners to be extremely open to discussing such practices and often quite critical of existing procedures. With few exceptions, almost every practitioner I spoke to could provide an insight as to how a particular procedure, protocol, or form could be changed to better enhance women's safety. Even though the relationship of the woman who is battered to the practitioner who processes her case is organized by processes extralocal to the woman or to the practitioner's everyday experience, changing that relationship can occur on the local level. An audit conducted by an interdisciplinary team produces an agenda for change to which policy makers are in many ways compelled to respond. The audit shows how things really work and it engages practitioners in the system in revealing this story. It would be difficult, although not impossible, for policy makers to shelve a report like this.

The Audit as an Investigative Tool

Certified public accountants conduct audits using generally accepted accounting principles, often referred to as GAAP. I am suggesting that the findings of my investigation in the Duluth court system can provide a similar framework for persons interested in reforming the criminal justice system's approach to responding to domestic assault cases. I am not trying at this point to provide all of the details of an audit but to lay out its general principles in three areas: the 
definition of safety, or what the team is looking for; the audit process, or how the team looks for it; and audit objectives, or how the audit will lead to change.

\section{The Definition of Safety}

A safety audit must start from some premise about what constitutes safety for battered women. Throughout my investigation I asked practitioners and advocates what compromises victim safety. There was almost universal agreement that outsiders, whether that be police officers, therapists, judges, or clergy, must intervene in these cases in ways that account for the context in which the violence is being used and experienced. Contextualizing the violence meant different things to practitioners and their definitions often related to their positions within the system. I have summarized below the most significant ways that these practitioners and advocates translated the notion of contextualizing the violence in the criminal court processes. In order for victim safety to be fully incorporated into case management routines, each interchange in the process must account for:

(1) The pattern of abuse

A domestic assault-related crime, such as trespass, criminal damage to property, violation of a protection order, or kidnapping, is rarely an isolated incident of violence or abuse. In order to take measures which maximize the chance of providing the victim ongoing protection from further abuse, attempts should be made to understand the context in which violence was used by eliciting and recording information which documents the pattern of coercion, intimidation, or violence associated with the case. An informed intervention must account for who is being harmed by the violence and the extent of the harm being done.

\section{(2) Power differentials}

A battered woman and her abuser are never in equal positions of power. Social relations of power in society, coupled with the power that comes from a sustained pattern of coercion, intimidation, and violence, place the perpetrator in a position of power over the victim and make the victim vulnerable to pressure, intimidation, and retaliation by the offender. The adversarial nature of the criminal court process frequently places the victim in opposition to the offender. Investigations and case processing need to acknowledge that domestic assaults do not involve two autonomous 
parties. An ongoing economic and social connection between the victim and offender mediates every statement, affidavit, and action.

(3) The particulars of the case

The criminal justice system processes discrete incidents of abuse and may work with serious and dangerous offenders as misdemeanants. Practitioners should enact safety and intervention measures based on the particulars of the case rather than on predetermined legal or institutional categories. Some misdemeanors are in fact more volatile and more likely to result in serious harm than some felony cases. Precautions should be based on the local and particular experiences of the victim rather than on generalized categories based on laws or other criteria (see sentencing matrix in chapter 8).

(4) Potential dangers to a victim of a fragmented response

There are literally dozens of actions taken on a case by various practitioners. Practitioners' work routines, including communication routines, should strengthen the connections of various practitioners in responding to a case so that victim safety is not compromised by a fragmented and poorly coordinated response. Examples might include establishing a system of preserving key 911 tapes to enhance the prosecutor's ability to place controls on a defendant; creating access for child protection workers and victim advocates to police investigation and arrest reports; ensuring that supervised release agents and probation officers have access to past police reports and OFP affidavits when preparing recommendations to the court on victim safety measures; and ensuring that case-related reports, such as police reports or presentence investigations, address victim safety.

(4) Victim perception of danger

No scale can accurately predict which offender will kill or seriously injure his partner. However, ample evidence exists to suggest that victims of homicide or attempted homicide often make several attempts to tell others about the danger but are ignored. How is the victim's perception of danger accounted for in the processing of a case? At what point is her knowledge screened out of the information gathering and at what point is it given an authorized place in the construction of the case? 
(5) The differences in women's lives

There is no universal battered woman. Race and class positions result in differing impacts of the same treatment. For example, Lawrence Sherman's Milwaukee study of recidivism following the impact of police making arrests compared to that of police issuing warnings showed that married and employed men were less likely to reoffend when arrested rather than warned. Unmarried unemployed men of all ethnic backgrounds in the study were more likely to reoffend when arrested rather than warned (Sherman, 1992). Only a handful of men in either group were prosecuted making the impact of legal intervention unclear. We might speculate that an approach which brings the legal system into the relationship but does not follow through with using the power of the state to control the offender can make some women more vulnerable to abuse.

(6) The presence of imminent danger

Assuming that no community could nor should necessarily try to respond to every assault of a woman as if she were about to be killed, we are faced with the problem of determining at what level to respond to physical violence against intimate partners. Insisting on a legal response that treats all acts of physical force, every shove, every push, every slap, as if these actions will escalate to homicide would be basing our work on a false premise and would so overload the system that all cases would suffer. But so far, overreacting to assaults has not been a significant problem. Instead, cases which are in fact quite dangerous are being conceptualized and processed as would be an isolated slap or a bar room fight between two people with no ongoing relationship. In addition, the legal process is not designed for quick action in situations that pose imminent danger.

\section{Methods}

The methods of the audit would parallel my own: observation of work settings and processing interchanges, texts analysis, and interviews with practitioners. The activities would begin with mapping the community's system with charts similar to those in Appendix B. Each work setting and its corresponding interchanges need to be detailed in these maps in order to determine all of the possible points at which victim safety can be implicated in the case management procedures. The team would conduct an analysis of each interchange, which therefore becomes the unit of 
analysis for the audit. The key elements for analysis at each interchange are technology, resources, procedures, and texts.

Prior to conducting interviews and observations, auditors would design worksheets to be used at each observation covering these four areas of inquiry. Each interchange may require several observations and team discussions about the auditors' observations and findings.

The auditors' worksheets should not be seen as an instrument to establish pre-formulated categories of items to look for in an audit. Their purpose would be to guide the auditor, not limit the scope of inquiry or restrict the auditors' use of their own knowledge and experience. It is important in structuring an investigation such as this to avoid putting boundaries around it. After all, the whole purpose here is to make visible what has become invisible. The Duluth study can act as a beginning point to frame auditors' worksheets.

The worksheet on technology is generally trying to help the auditors and the practitioners at a given work setting uncover all of the ways in which the technology of that setting impacts the potential for safety measures being built into the system's infrastructure. For example, I had several rather long conversations at the dispatch center, police department, and probation department about the lack of coordination in the city, county, and state computer systems and what this means for victim safety. The inability of dispatchers to make information that is contained in these data bases immediately available to police officers responding to a call has definite safety implications for both the police and battered women. The solution requires some long-range planning but not necessarily an expensive overhaul of the computer systems.

Similarly, the worksheet on resources is designed to uncover all of the resources readily available to practitioners as they do their work. It may be, for example, that there is a shelter in town but that it is usually full when police try to house a woman and her children there. The lack of shelter facilities changes what actions police can and should take. Perhaps the resource that will be found most lacking is adequate time to spend on the case. I found when interviewing social workers for a related but separate piece of research that child protection workers were strongly discouraged from using the criminal court process to keep violent fathers from having contact 
with their children. It was a resource that was not available to them as practitioners and its unavailability explained why they were prone to recommending placement in foster care for children who were being repeatedly exposed to violence against their mothers. ${ }^{58}$ Many activists in the battered women's movement, including myself, had speculated that child protection workers' initiatives to place these children in foster care was a manifestation of their victimblaming attitudes rather than seeing them as the result of concrete work processes.

The worksheet on processes is designed to help the auditor explore with the practitioner how procedures and processes used at an interchange can compromise or centralize women's safety. The auditor is asking questions related to the definition of safety. Are the practitioner's activities and the procedures being applied at this point in the case organized in a way that accounts for the pattern of abuse, the power differentials, and the victim's sense of danger? The auditors are trying to explicate how this specific process or procedure is consequential to a woman's safety and how it might be altered to account for safety.

The most complex aspect of the audit will be the analysis of the active role of texts in the provision of victim safety. The team needs to gather every text related to an interchange and discover how the text-regulatory, administrative, narrative, or argument-frames and organizes the practitioner to act in institutionally authorized ways. Over the course of the year that I observed interchanges I began to develop a series of questions that helped focus my observation and interviews. I was looking for the text in action, not as an inert object to analyze in and of itself. Below are some of the questions that emerged from my readings of D. E. Smith's work as I began finding patterns in my own observations.

At each interchange:

\footnotetext{
${ }^{58}$ I am referring here to a series of meetings we held to discuss the emerging notion of charging women who are battered and cannot (or will not) keep their abuser out of the home with "failure to protect" and placing their children in foster care. Child protection workers frequently give a woman the choice of getting a protection order which excludes her abuser from the home or losing her children to foster care. The woman files for the protection order but the abuser violates the order and moves back home. If she doesn't call the police to have him arrested, the social service department is forced to place the children in foster care. We have been proposing that the social worker go over to the home, witness him there, file charges against him for violation of a protection order, and have the court incarcerate him rather than implement a de facto incarceration of the children. This resource has never been institutionally available to workers.
} 
- How does the production or use of texts at this interchange occur?

- What texts (policies, laws, rules, ordinances) regulate what occurs at this interchange?

- What administrative texts are used in this interchange?

- What reports, recommendations, or statements are used or produced at this interchange?

- What frames were used in the production or reading of texts at this interchange?

- Who is the intended reader of the text being produced or altered at this interchange?

- How does the woman become actionable in this interchange, and how does the man become actionable?

For each text:

- How does this text influence what information about the case is filtered out of the process?

- What information related to contextualizing the incident (safety) drops out because of the work of this text?

- How does this text act to create priorities?

- How does anticipating an intended reader shape the production of this text?

- How does this text organize the work of the practitioner?

- How does this text organize the writing and reading done here?

- How does the method of production of this text influence the practitioner to make certain observables or pieces of information visible and others invisible?

- How does this text allow for the retention of information on the pattern of abuse? On power differentials? On the woman's and man's social position? On the immediate danger? On the woman's perception of danger?

This is not meant to be a complete list of considerations on the text but an example of the kinds of questions auditors need to have in their heads as they begin their observations. Most likely several members of a team will observe a particular interchange. Much of what is to be discovered will come out of team meetings to discuss these interviews and observations. 


\section{The Audit Objectives}

Finally, the team would work with policy makers in the various agencies that participate in the processing of these cases to recommend a comprehensive plan to reorganize work settings and

processing procedures at each point of interchange to incorporate victim safety.

The final report should explicate how victim safety was marginalized at each interchange in the sequence of interchanges that constitute case processing and make recommendations for specific changes to centralize victim safety. Many of these suggested changes will have come directly from practitioners in the field. In many cases they will be the best people to present these recommendations to policy makers. The audit team should see practitioners as co-investigators in the process and subsequently as colleagues in designing the changes. Using a participatory approach in designing the changes will simultaneously reduce resistance to change and develop on-site trainers on the new methods of case processing.

\section{Conclusion}

These kinds of regimes usually have two inter-related pieces of organization: a political apparatus and a bureaucracy.... The notion of a politico-administrative regime operates as a heuristic device for investigating empirically how ruling works, how the lives of people are regulated and governed by institutions and individuals vested with authority (G. W. Smith, 1990, pp. 629-632).

Using the strategy of conducting a safety audit will lead to an explication of how that regime works. As a co-worker recently said at one of our staff meetings discussing how as a group we could expand my research to a systematic audit of the Sixth Judicial District's criminal and civil court system, "This is really big, it's as big as when we first proposed that everybody sign policies fifteen years ago."

I have focused my analysis on the processing of a criminal court case and safety for battered women. However, the concept of using D. E. Smith's work to conduct an audit of institutions with a specific social change objective in mind can be applied in a variety of feminist and progressive projects. Using a similar audit format, an investigator could look for the concrete practices that produce racialized policing or limit cancer patients' control over their medical care 
or compromise the safety and integrity of high school students who report sexual harassment. I use these examples because they are all projects I have begun to work on with activists in other fields. This project has answered for me the question I posed in my introduction: What should I do next? 


\section{REFERENCE LIST}

Abramovitz, M. (1988). Regulating the lives of women. Boston: South End Press.

Adams, D. C. (1988). Treatment models of men who batter: A pro-feminist analysis. In K. Yllö \& M. Bogard (Eds.). Feminist perspectives on wife abuse (pp. 176-199). Newbury Park. CA: Sage.

Allard, S. (1991). Rethinking battered woman syndrome: A black feminist perspective. I UCLA Women's Law Journal, 191, 193-98.

Bachman, R. (1992). Death and violence on the reservation: Homicide, family violence, and suicide in American Indian populations. New York: Auburn House.

Bersoff, D. N. (1986). Psychologists and the judicial system. Law and Human Behavior, 10, 151.

Brown, W. (1992). Finding the man in the state. Feminist Studies, 18, 7-33.

Browne, A. (1987). When battered women kill. New York: The Free Press.

Busch, R. \& Robertson, N. (1992). What's love got to do with it? An analysis of an intervention approach to domestic violence. Unpublished manuscript.

Buzawa, C. G. \& Buzawa, E. S. (1990). Domestic violence. London: Sage Publications.

Cain, M. \& Smart, C. (1989). Series editor preface. In C. Smart \& S. Sevenhuijsen (Eds.). Child custody and the politics of gender (pp. xi-xiii). New York: Routledge.

Campbell, J. C. (Ed.). (1995). Assessing dangerousness. Thousand Oaks, CA: Sage Publications.

Chester, B., Robin, R. W., Koss, M. P., Lopez, J., \& Goldman, D. (1994). Grandmother dishonored: Violence against women by male partners in American Indian communities. Violence and Victims, 9, 249-258.

Coleman, D. H. \& Straus, M. A. (1983). Alcohol abuse and family violence. In E. Gottheil, A. Durley, I. E. Skolada, \& H. M. Wasman (Eds.). Alcohol, drug abuse and aggression (pp. 104-132). Springfield, MN: C. C. Thomas.

Coley, S. M. \& Beckett, J. O. (1988). Black battered women: A review of empirical literature. Journal of Counseling and Development, 66, 266-270.

Costain, A. N. (1982). Representing women: The transition from social movement to interest group. In E. Boneparth (Ed.). Women, power and policy (pp. 19-37). New York: 


\section{Pergamon Press.}

Currie, D. H. (1990). Battered women and the state: From the failure of theory to a theory of failure. The Journal of Human Justice, $1,2$.

Dasgupta, S. D. \& DasGupta, S. (1996). Public face, private space: Asian Indian women and sexuality. In N. Maglin \& D. Perry (Eds.). Bad girls, good girls: Women, sex and power in the nineties (pp. 226-242). Brunswick, NJ: Rutgers University Press.

Dasgupta, S. D. \& Warrier, S. (1996). In the footsteps of "Arundhati": Asian Indian women's experience of domestic violence in the United States. Violence Against Women, 2, 238259.

Davies, J. (1995). An approach to legal advocacy for individual battered women. Unpublished manuscript.

Dobash, R. E. \& Dobash, R. (1979). Violence against wives. New York: The Free Press.

Dobash, R. E. \& Dobash, R. (1992). Women, violence \& social change. New York: Routledge.

Dodson, G. E. (1982). Patriarchy as a conceptual trap. Wesley, MA: Roundtable Press.

Dutton, D. G. \& Goland, S. (1995). The batterer: A psychological profile. New York: Basic Books.

Eberle, P. (1982). Alcohol abusers and non-users: A discriminating function analysis. Journal of Health and Social Behavior, 23, 157-189.

Edleson, J. L. \& Syers, M. (1991). The effects of group treatment for men who batter: An 18month follow-up study. Research in Social Work Practice, 1, 227-243.

Edwards, S. S. M. (1989). Policing 'domestic' violence: Women, the law and the state. London: Sage Publications Ltd.

Faigman, D. L. (1986). The battered woman syndrome and self-defense: A legal and empirical dissent. Virginia Law Review, 72, 619, 626-636.

Flitcraft, A. H. (1992). American Medical Association diagnostic and treatment guidelines on domestic violence. Archives of Family Medicine, 1, 39-47.

Ford, D. A. (1983). Wife battery and criminal justice: A study of victim decision-making. Family Relations, 32, 463-475.

Ford, D. A. (1991). Prosecution as a victim power resource: A note on empowering women in violent conjugal relationships. Law \& Society Review, 25, 313-334. 
Foucault, M. (1979). Discipline \& punish: The birth of the prison. New York: Vintage Books.

Fraser, N. (1989). Unruly practices: Power, discourse, and gender in contemporary social theory. Minneapolis: University of Minnesota Press.

Freeman, J. (1975). The politics of women's liberation: A case study of an emerging social movement. New York: David McKay.

Frieze, I. H., \& Knoble, J. (1980). The effects of alcohol on marital violence. Paper presented at the annual meeting of the American Psychological Association. Montreal, Canada.

Garfinkel, H. (1967). Studies in ethnomethodology. Englewood Cliffs, NJ: Prentice Hall.

Gondolf, E. W. (1985). Men who batter: An integrated approack: to stopping wife abuse. Holmes Beach, FL: Learning Publications.

Gondolf, E. W. \& Russell, D. (1986). The case against anger control treatment programs for batterers. Response, 9, (3) 1-9.

Green, B. S. (1983). Knowing the poor: A case-study in textual reality construction. London: Routledge \& Kegan Paul.

Hale, S. (1990). Controversies in sociology: A Canadian introduction. Toronto: Copp Clark Pittman Ltd.

hooks, b. (1981). Ain't I a woman: Black women and feminism. Boston: South End Press.

hooks, b. (1984). Feminist theory: From margin to center. Boston: South End Press.

Jones, A. (1980). Women who kill. New York: Fawcett Columbine.

Kappeler, S. (1995). The will to violence: The politics of personal behavior. New York: Teachers College Press.

Keyes, J. T. D. (1996, April). What turns boys into brutes? Homemaker's Magazine, pp. 54-61.

Leacock, E. (1994). Montagnais women and the Jesuit program for colonization. Rapid City, SD: South Dakota Coalition Against Domestic Violence and Sexual Assault.

Mahoney, M. (1991). Legal images of battered women: Redefining the issue of separation. Michigan Law Review, 90 (1)

Mann, B. (1986). Radical education or therapy. In E. Pence (Ed.). In our best interest: $A$ process for personal and social change. Duluth, MN: Minnesota Program Development, Inc. 
McAllister, P. (Ed.). (1982). Reweaving the web of life: Feminism and nonviolence. Philadelphia: New Society Publishers.

McMahon, M. \& Pence, E. (1995). Doing more harm than good? In E. Peled, P. G. Jaffe, \& J. L. Edleson (Eds.). Ending the cycle of violence (pp. 186-206). Thousand Oaks, CA: SAGE Publications.

Michael, R. T., Gagnon, J. H., Laumann, E. O., \& Kolata, G. (1994). Sex in America: A definitive survey. New York: Little, Brown.

Mills, C. W. (1967). Power, politics, and people. New York: Oxford University Press.

Minnesota rules of court: State and federal. (1996). St. Paul: West Publishing Company.

Morgan, R. (Ed.). (1970). The women's revolution [Introduction]. In Sisterhood is powerful (pp. xv-xlvi). New York: Vintage Books.

National Clearinghouse for the Defense of Battered Women. (1995). Statistics packet, 3rd edition. Philadelphia: Author.

National Council of Juvenile and Family Court Judges (Ed.). (1994). Family violence: A model state code. Reno, NV: Conrad N. Hilton Foundation.

National Council of Juvenile and Family Court Judges (Ed.). (1996). Family violence legislative update. Reno, NV: Conrad N. Hilton Foundation.

Okum, L. (1986). Woman abuse: Facts replacing myths. Albany, NY: State University of New York Press.

Olsen, F. (1983). The family and the market. Harvard Law Review, 90, 1497-1578.

Pagelow, M. D. (1981). Women-battering: Victims and their experiences. Beverly Hills, CA: Sage.

Pateman, C. (1987). Feminist critique of the public/private dichotomy. In A. Phillips (Ed.). Feminist and equality (pp. 103-126). New York: New York University Press.

Paymar, M. (1993). Violent no more: Helping men end domestic violence. Alemeda, CT: Hunter House.

Pence, E. (1983). The Duluth domestic abuse intervention project: Toward a coordinated community response to domestic abuse. Hamline Law Review, 6, 247-280.

Pence, E. (1988). Shifting from community collusion to community confrontation. In P. L. Caesar \& K. Hamberger (Eds.). Treatment models for spouse abusers (pp. 69-77). New York: Springer. 
Pence, E. (1996). Coordinated community response to domestic assault cases: $A$ guide for policy development. Duluth, MN: Minnesota Program Development, Inc.

Pence, E. \& Paymar, M. (1993). Education groups for men who batter: The Duluth model. New York: Springer.

Pence, E. \& Ritmeester, T. (1992). A cynical twist of fate: How process of ruling in the criminal justice system and the social sciences impede justice for battered women. University of Southern California Review of Law and Women's Studies, 2, 255-292.

Pleck, E. (1989). Criminal approaches to family violence 1640-1980. Chicago: University of Chicago Press.

Ptacek, J. (1995). Disurder in the courts: Judicial demeanor and women's experience seeking restraining orders. Unpublished dissertation.

Pollock, S. \& Sutton, J. (1985). Father's rights, women's losses. Women's Studies International Forum, 8, 593-599.

Rich, A. (1979). Lies, secrets, and silence: Selected prose, 1966-1978. New York: W. W. Norton and Company.

Rich, A. (1980). Compulsory heterosexuality and lesbian existence. Signs, 5, 631-660.

Richie, B. (1985). Battered black women: A challenge for the black community. The Black Scholar, 16, 40-44.

Rothway, H. J. (1996). Guilty: The collapse of criminal justice. New York: Random House.

Ryan, W. (1972). Blaming the victim. New York: Vintage Books.

Saunders, D. G. (1992). Women battering. In R. T. Ammerman \& M. Hersen (Eds.). Assessment of family violence: A clinical and legal sourcebook (pp. 208-235). New York: Wiley.

Schechter, S. (1982). Women and male violence. Boston: South End Press.

Scott, J. W. (1988). Gender and the politics of history. New York: Columbia University Press.

Sherman, L. W. \& Berk, R. A. (1984). The specific deterrent effects of arrest for domestic assault. American Sociological Review, 49, 261-272.

Sherman, L. W. (1992). Policing domestic violence: Experiments and dilemmas. New York: Free Press.

Smart, C. (1989). Feminism and the power of law. New York: Routledge 
Smith, B. (Ed.). (1983). Home girls: A black feminist anthology. New York: Kitchen Table: Women of Color Press.

Smith, D. E. (1976). K is mentally ill: The anatomy of a factual account. Sociology 12 (1): 2553.

Smith, D. E. (1987). The everyday world as problematic. Boston: Northeastern University Press.

Smith, D. E. (1990a). The conceptual practices of power. Boston: Northeastern University Press.

Smith, D. E. (1990b). Texts, facts, and femininity: Exploring the relations of ruling. New York: Routledge.

Smith, G. W. (1990). Political activist as ethnographer. Social Problems, 37, 629-648.

Steinmetz, S. \& Straus, M. A. (1977). The battered husband syndrome. Victimology, 2, 314.

Straus, M. A. (1979). Measuring family conflict and violence: The conflict tactics scale. Journal of Marriage and the Family, 41, 75-88.

Straus, M. A. (1989). Assaults by wives on husbands: Implications for primary prevention of marital violence. Paper presented at the meeting of the American Society of Criminology.

Straus, M. A., Gelles, R. J., \& Steinmetz, S. K. (1980). Behind closed doors: Violence in the American family. Garden City, NY: Anchor Books.

Taylor, G. (1993). Child custody and access. Vis à Vis: National Newsletter on Family Violence, 10, 3. Canadian Council on Social Discourse.

Tremper, C. R. (1987). Organized psychology's efforts to influence judicial policy making. American Psychologist, 42, 496.

Wahlen, J. \& Smith, D. E. (1994). Texts in action. Unpublished manuscript.

Walker, G. A. (1990). Family violence and the women's movement: The conceptual politics of struggle. Toronto: University of Toronto Press.

Walker, L. E. (1979). The battered woman. New York: Harper and Row.

Walker, L. E. (1984). The battered woman syndrome. New York: Springer.

Weeks, A. D. (1990). The microsociology of everyday life. In S. M. Hale (Ed.). Controversies in sociology: A Canadian introduction. Toronto: Copp Clark Pitman Ltd. 
Weisberg, D. K. (Ed.). (1993). Feminist legal theory: Foundations. Philadelphia: Temple University Press.

When judges fail battered women. (1996, March 18). SPEAKING UP: News and Tips for the Domestic Violence Community [Newsletter of the Family Violence Prevention Fund in collaboration with the National Resource Center on Domestic Violence], 2 (6) 1.

Wittner, J. (In press). Reconceptualizing agency in domestic violence courts. In N. Naples (Ed.) Rethinking feminism and activism. New York: Routledge.

Yllö, K. \& Bograd, M. (1988). Political and methodological debates in wife abuse research. In K. Yllö \& M. Bograd (Eds.). Feminist perspectives on wife abuse. Newbury Park, CA: Sage. 
APPENDICES 


\section{APPENDIX A: $\quad$ TRANSCRIPT FROM RASMUSSON HEARING}

\section{(Thursday) (January 11, 1996)}

(Whereupon, the following proceedings were duly held in open court:)

The Court: Let's go on record in the State against Kern Andrews matter. Rasmussen Hearing, as I understand it, this afternoon. Now, there's no written motion in the file. What is the issue here?

Ms. Parker: Your Honor, at the pre-trial conference in this matter, I had made a-motion to dismiss for lack of probable cause. Ms. Hewler asked to have a hearing where she could bring in - I thought it was Mrs. Andrews but I see she also has the officers here. It's our position, essentially, based upon the report, that there's no probable cause for assault in the fifth degree.

The Court: All right. And you disagree with that, Ms. Hewler; and are you prepared to call some witnesses or-

Ms. Hewler: That's right, Your Honor.

The Court: All right. Proceed.

Ms. Hewler: Thank you. Our first witness would be Cindy Andrews.

The Court: Go ahead.

\section{TESTIMONY OF CINDY ANDREWS,}

Q What I would like to do is go into that a little bit with you. At the time of this incident on January 1st, did you have an Order for Protection in place?

A No, I did not.

Q You've subsequently obtained one, is that right?

A Yes.

Q Had you had any Order for Protection in place throughout the nine-year relationship, or at any time?

Ms. Parker: Judge, I'm going to object to this line of questioning. It's irrelevant to this. The issue at hand is whether there's probable cause for the assault charge which occurred on January 1 st.

Ms. Hewler: Your Honor, I expected that objection and the State's reasoning here is that the type of assault that we're talking about, as the Court will hear in the next few minutes, does not involve actual harm being inflicted. It involves physical confrontation but without actual harm. And the theory-the section of the statute the State is proceeding under is Section 609.224 , subdivision 1, parenthesis (1), as well as (2), which indicates that it is a misdemeanor to commit an act with intent to cause fear in another of immediate bodily harm or death. The State's theory here is that Ms. Andrews was made to be afraid and her fear is based on the whole history of this relationship. That the history of the relationship is relevant to the determination of whether she was afraid on January lst of 1995.

The Court: I'll let it go for a while. You don't have to go on forever in detail with regard to prior orders and the like.

Ms. Hewler: Okay.

Q (Ms. Hewler, continuing) Briefly, Ms. Andrews, can you tell us if you've had two prior Orders for Protection?

A Yes, I have.

Q When did you obtain the first order?

A The first order was July of ' 89 , and second order was the summer of ' 93 . 
Q Has there been a history of physical violence in your relationship with Mr. Andrews?

A Yes, there has.

Q And can you describe briefly for the Court the time period under which that has happened?

A Basically, throughout out whole marriage he's been angry and abusive towards me and towards other people, even people that he works with.

Q Okay, and in your-the experiences that you had in the past with Mr. Andrews, was that on your mind as you were relating to him on January 1, 1995?

A Yes, like there's a pattern. The more that I try not to make him angry or talk with him and to work, you know, things the way he wants to work them, he gets more agitated and his anger just escalates.

Q Did you feel that was happening on this particular occasion?

A Yes, I did.

Q What made you feel that way; what was happening?

A Just from the time he walked into the door and I could tell that he was angry, and when I asked him to leave he refused; and he started pacing back and forth on the floor, and he started yelling.

Q What was the yelling, do you remember?

A About his rights. He had a right to be in the home when I asked him to leave, and he had a right to take the things that he was taking because they were his.

(Two police officers testified here.)

Ms. Hewler: Your Honor, the State has no other witnesses. We'd ask our officers to wait.

Ms. Parker: Your Honor, we're not putting any witnesses on.

The Court: It's your motion; do you want to argue it?

Ms. Parker: Yes, I do, Your Honor.

Judge, my client was obviously arrested for assault in the fifth degree, and I think the only testimony we have, really, is Ms. Andrews' testimony that she was afraid of him, Mr. Andrews. But if you consider what she then further testified about that - first of all, she tried to block him down in the basement from taking property, and then he in turn goes up and calls 911 . She follows him back up and then she disconnects the phone. While at one time she is saying she's afraid of him and being afraid of being assaulted by him, she interferes with calling the law. People want law-enforcement to come if they were really afraid they were in harm or danger from another side. So it's our contention no assault took place based on the testimony provided here today that had occurred. There was no threats made to her. There was no physical injury made to her and that this matter should be dismissed. There is no probable cause for it.

The Court: Ms. Hewler.

Ms. Hewler: Your Honor, I would argue there is probable cause. The state clearly indicated that it is an assault to place someone in fear of immediate bodily harm. That's how we're proceeding here. Yes, there were no threats. Yes, there would be no injuries or you would be having been hearing about the today in Court. But there was definitely an assault. It occurred because we saw the evidence of it when the officers go to the scene. It's incorrect that defense counsel argues that all we have is Ms. Andrews's testimony. That isn't true. We have two officers who have come in and said they saw the effects on her. They saw that she was shaken up. That she was scared. Officer Dixon said she was fearful. She was very scared. Officer 
Bronte described her as being upset and in tears. That she appeared timid. That she appeared to be afraid of the Defendant. That substantiated what she has come into court and told the Court about. It was suggested that normal person wouldn't unplug the phone, but this isn't a normal situation. That's the whole point of this particular case. This is not a normal situation whatsoever. This is a situation where there has been an extended history of violence. It's a situation that meant something far different. The actions of the Defendant is far different to Ms. Andrews than would be true in a, quote, "normal" unquote, situation of relationship. That in a normal relationship a push causing one to have a step back may be annoying. It may be rude. It may be any number of things, you know, intimidating probably. But in this situation with the history of what this woman has gone through has meant something far different. I believe she testified to that very clearly when she said she knew what his patterns were, what his habits were, and if he was angry that he wouldn't leave the home. That she sensed something worse was going to happen. At the most, everything put together, his anger towards her, his refusal to leave combined with the push, culminated in the push of hers. Certainly, although she was not physical harmed, she certainly was very afraid that something was going to happen to her and she testified to that clearly. This is what Subsection 1 of the statute is talking about. She was placed in fear of immediate bodily harm. She wasn't afraid, necessarily, that something was going to happen a month later. It was going to be right then. I don't think it's hard to believe that a woman who has had two Orders for Protection in the past nine years in a violent situation would be afraid. Obviously, nothing had stopped her husband-and obviously, things were not better.

She was thinking of the children not having to deal with the police coming to her home one more time. That doesn't mean there's lack of probable cause here. That means this is a woman who was used to dealing with a violent man. She knew what was likely to happen. Thankfully, because the officers were there to intervene it did not happen. I would ask the Court to find there is probable cause for an assault charge.

The Court: Wait a minute. We have to deal with it now or deal with it later. The State does not say it's against the law to place one in fear of bodily harm-I don't have any qualms about the fact she was in fear of bodily harm. The statute you're talking about is an act done with intent to cause fear of bodily harm. So-

Ms. Hewler: That's right.

The Court: So your argument should not be related to her state of fear, which I don't question with the history, etcetera, but his intent with what he was doing. That's where the problem is.

Ms. Hewler: Okay, the State argues that there was an intent to cause fear in Ms. Andrews of immediate bodily harm. This is a man who has an underlying history of being violent in his relationship. A push from him would mean something far different to his wife and [he] knew that. He knew that. He knew that he could make her afraid by pushing her. He knew that his voice - all of his actions because of what she has come to court to say-she knew how to read his signals. That was an intentional act on his part not to try to harm her. He didn't punch her. He didn't do the acts that he normally used in dealing with her. We're not talking about actual harm inflicted but that he actually caused fear in her. That's why I thought it important to describe the type of push that she experienced from him. It wasn't a push like-kind of brushing somebody out of the way like- "Get out of my way. I want to get some things." It wasn't like that. She described that he had light bulb in one hand and it was his forearm that pushed her. That action in that context and the prior intentional acts had committed against her caused her to obtain two Orders for Protection. That is what continued to cause fear in her of immediate bodily harm. And he did-he did achieve the result that he intended to achieve.

The Court: Anything from this side of the table? 
Ms. Parker: Judge, it just isn't there. There isn't any evidence showing that his intent was to harm her or even cause her to be afraid. He was going down there to get some personal property. She blocks his way. She turned around and called the police-probably his son called the police-but there are no verbal threats that he makes. No follow-through. You have her-claiming that there was a push but it's an insufficient basis for this matter to go to a jury trial.

The Court: Well, all right. I'm familiar with this case-not this case but these people-and I don't know how many hours we have in these proceedings at this particular point in time. This is a chaotic situation and I have no question that she was in fear. Now, I think the police did what they had to do under the circumstances. They were called to potential problems. But you're talking about taking into consideration all the circumstances when you determine intent, and I think you also have to take into consideration that she was blocking his path. I don't think that there is-you know, we're going to have to do this now or do it again. I don't think you'll be able to get it to a jury, to be frank, Ms. Hewler. I don't think there is enough to get it to a jury, and he would be saying the same old thing again. I don't like it, but I'm going to have to dismiss it for lack of probable cause. That is all.

(Proceedings concluded at 3:35 p.m.)

Ms. Hewler: Thank you, Your Honor.

Ms. Parker: Thank you, Your Honor. 


\section{APPENDIX B-1: $\quad$ IMMEDIATE INTERVENTION AND INITIAL INVESTIGATION: DISPATCHING SQUAD}

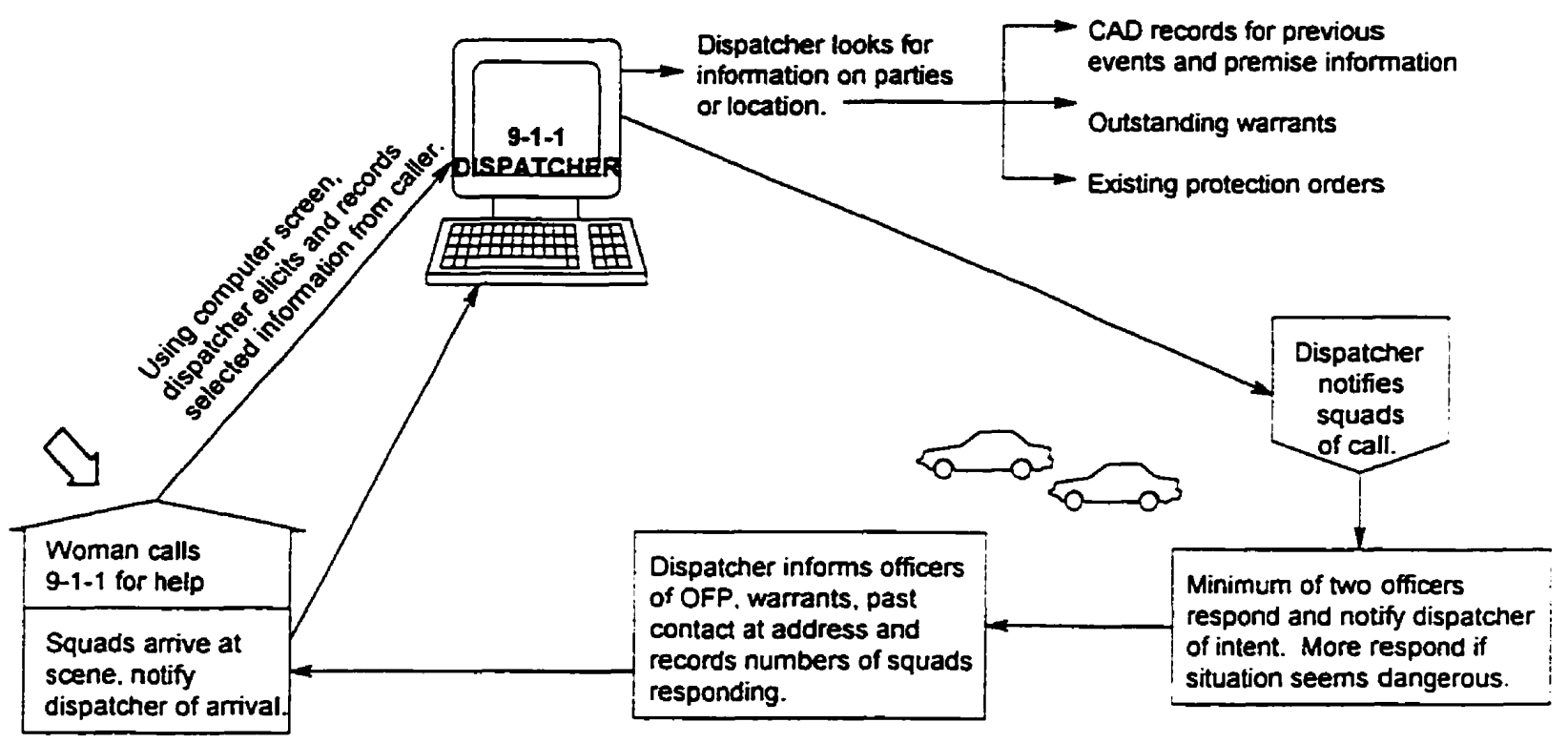

\begin{tabular}{|c|c|c|}
\hline & $\begin{array}{l}\text { All communication } \\
\text { on dispatch screen and }\end{array}$ & \\
\hline $\begin{array}{l}\text { CAD - Computer Aided Dispatch } \\
\text { OFP - Order for Protection } \\
\text { MDT - Mobile Data Terminal } \\
\text { ICR - Initial Complaint Report }\end{array}$ & $\begin{array}{l}\text { received on terminals at police } \\
\text { desk and patrol supervisor's } \\
\text { desk. ICR and summary of } \\
\text { information become the } \\
\text { watch report." }\end{array}$ & $\begin{array}{l}\text { Police desk officer prints } \\
\text { out watch reports at } \\
\text { conclusion of each shift. }\end{array}$ \\
\hline
\end{tabular}

This figure depicts the first 5 minutes of a case. The woman's call to 9-1-1 is mediated by the dispatcher's intake screen. Although the call is taped, typically the only written documentation of the call is a very brief summary of the communication between the dispatcher and the responding officer. The dispatcher's intake screen is designed to centralize the immediate safety of the responding officers and of the victim. The ongoing safety of the victim is not attended to in the information about the context of the violence and is not recorded and made a part of the permanent file. 


\section{APPENDIX B-2: $\quad$ IMMEDIATE INTERVENTION AND INITIAL INVESTIGATION: POLICE RESPONSE TO DOMESTIC CALL AND DECISION TO ARREST}

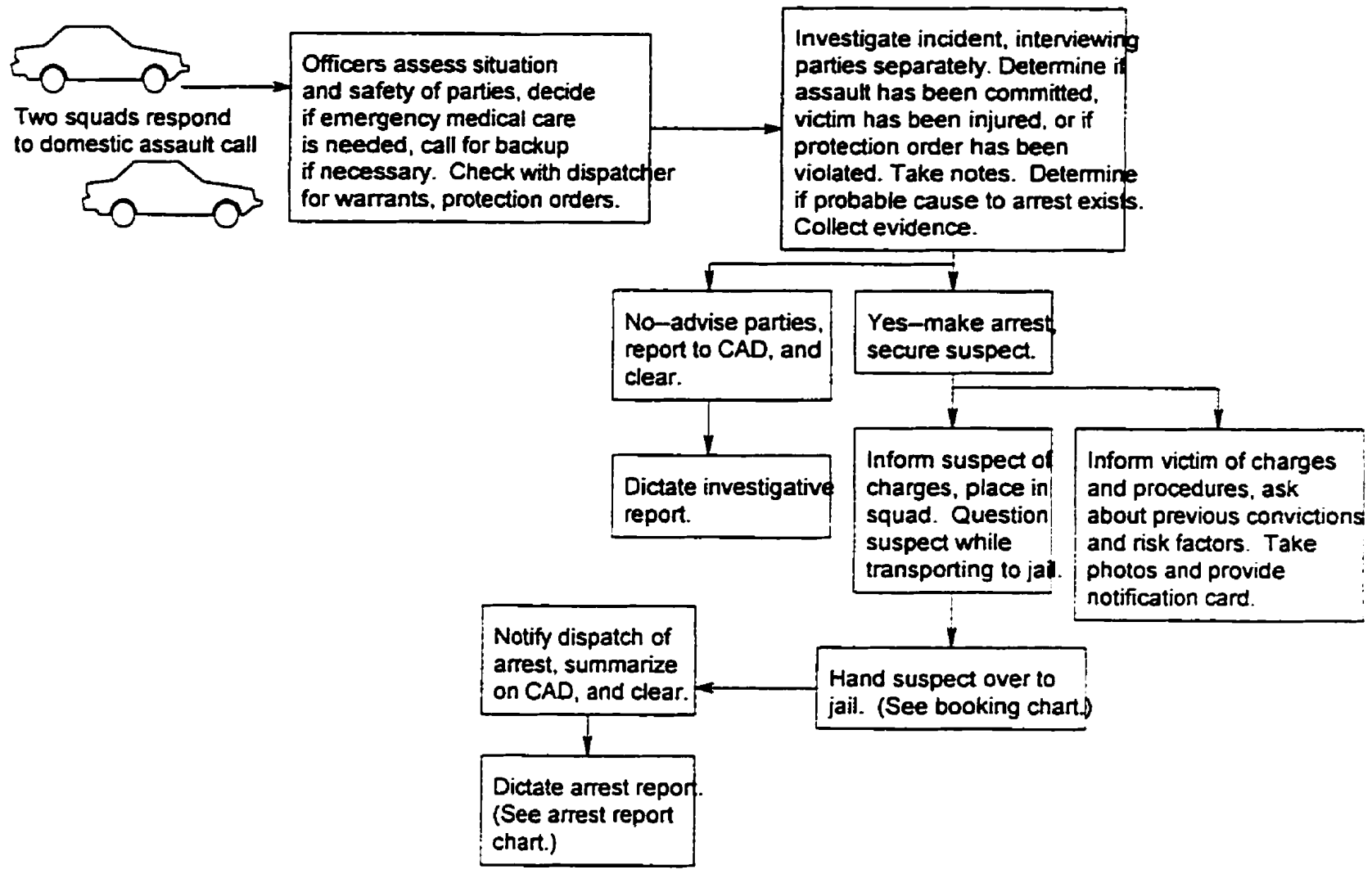

This figure depicts the second phase of a case. Responding officers assess the situation, keeping victim safety central through the use of the department domestic violence policy. The second box describes investigation of the incident. If the suspect is arrested, an advocate is called to provide follow-up advocacy to the victim. If the suspect is not arrested, the victims is given a card with the phone number of the shelter. 


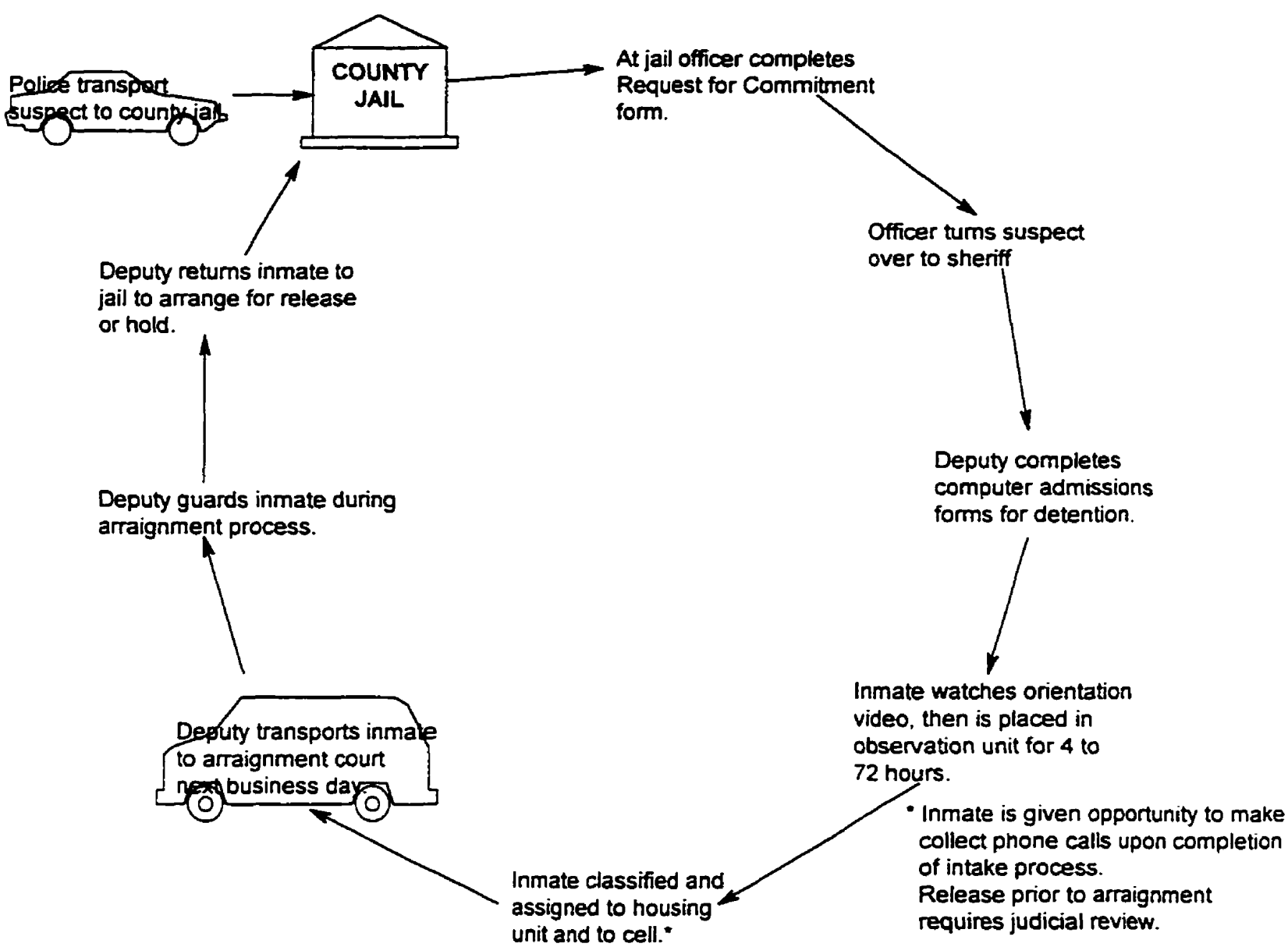

When the responding officer delivers the suspect to the jailer, booking procedures remind the jailer to contact the women's shelter and notify them of the arrest. The shelter sends an on-call advocate to visit the victim at her home to offer information and support. If a victim requests, the jailer may put a "number blocker" on the jail telephones to prevent the suspect from harassing her from jail. Release procedures require the jailer to notify a victim of the release of a suspect. 


\section{APPENDIX B-4: $\quad$ IMMEDIATE INTERVENTION AND INITIAL INVESTIGATION: ARREST REPORT PREPARATION AND PROCESSING OF A MISDEMEANOR DOMESTIC ASSAULT}

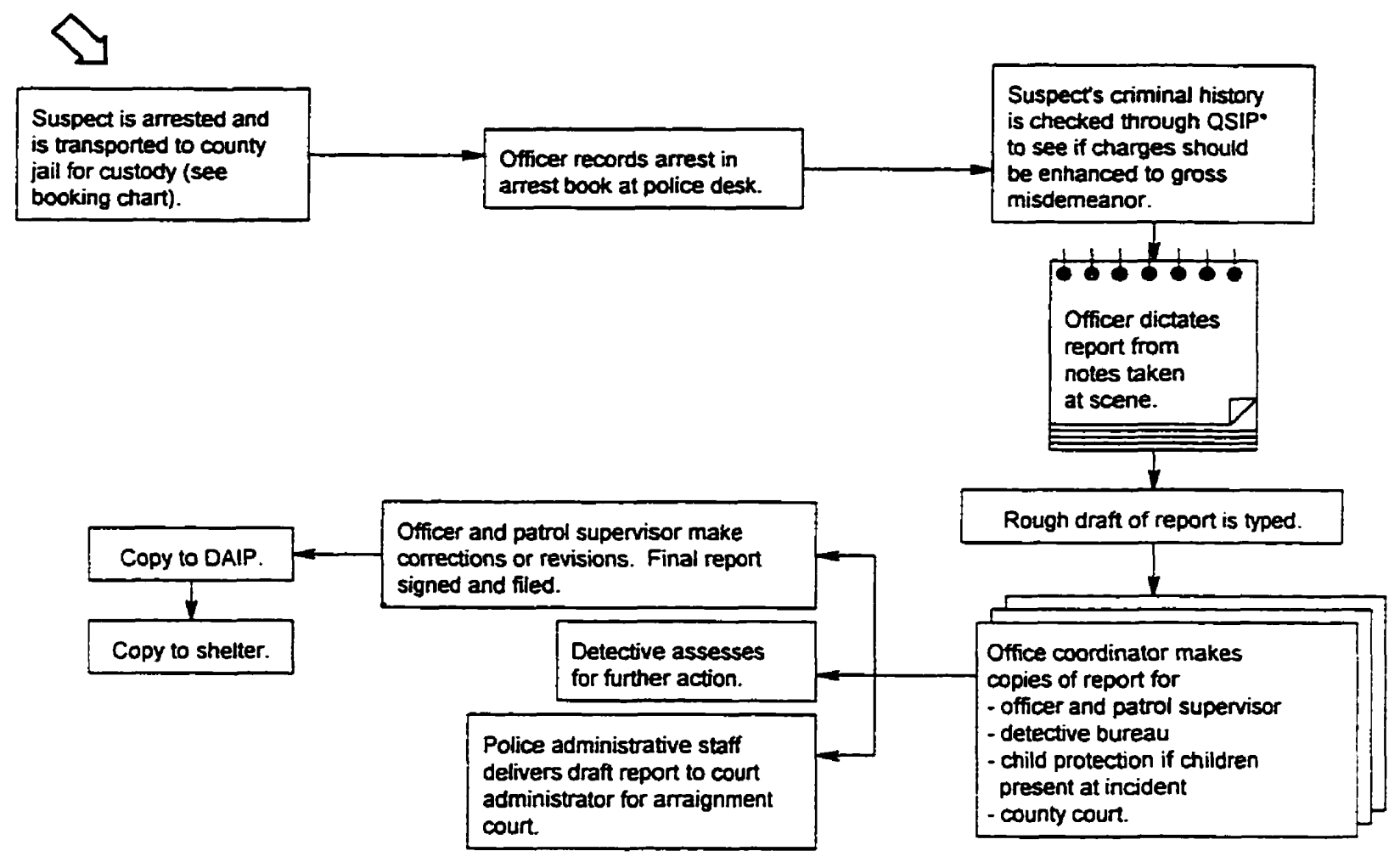

- QSIP - Query Subject in Process

When dictating a report on the arrest of the suspect, the officer uses the laminated card (Figure 14) as a guide. Details about the incident are described and the risk factors that the officers noted at the scene are included in the report, which becomes a permanent record. The report is distributed to practitioners as shown above. 


\section{APPENDIX B-5: $\quad$ IMMEDIATE INTERVENTION AND INITIAL INVESTIGATION: DETECTIVE BUREAU INVESTIGATION FOR GROSS MISDEMEANOR AND FELONY ASSAULT}

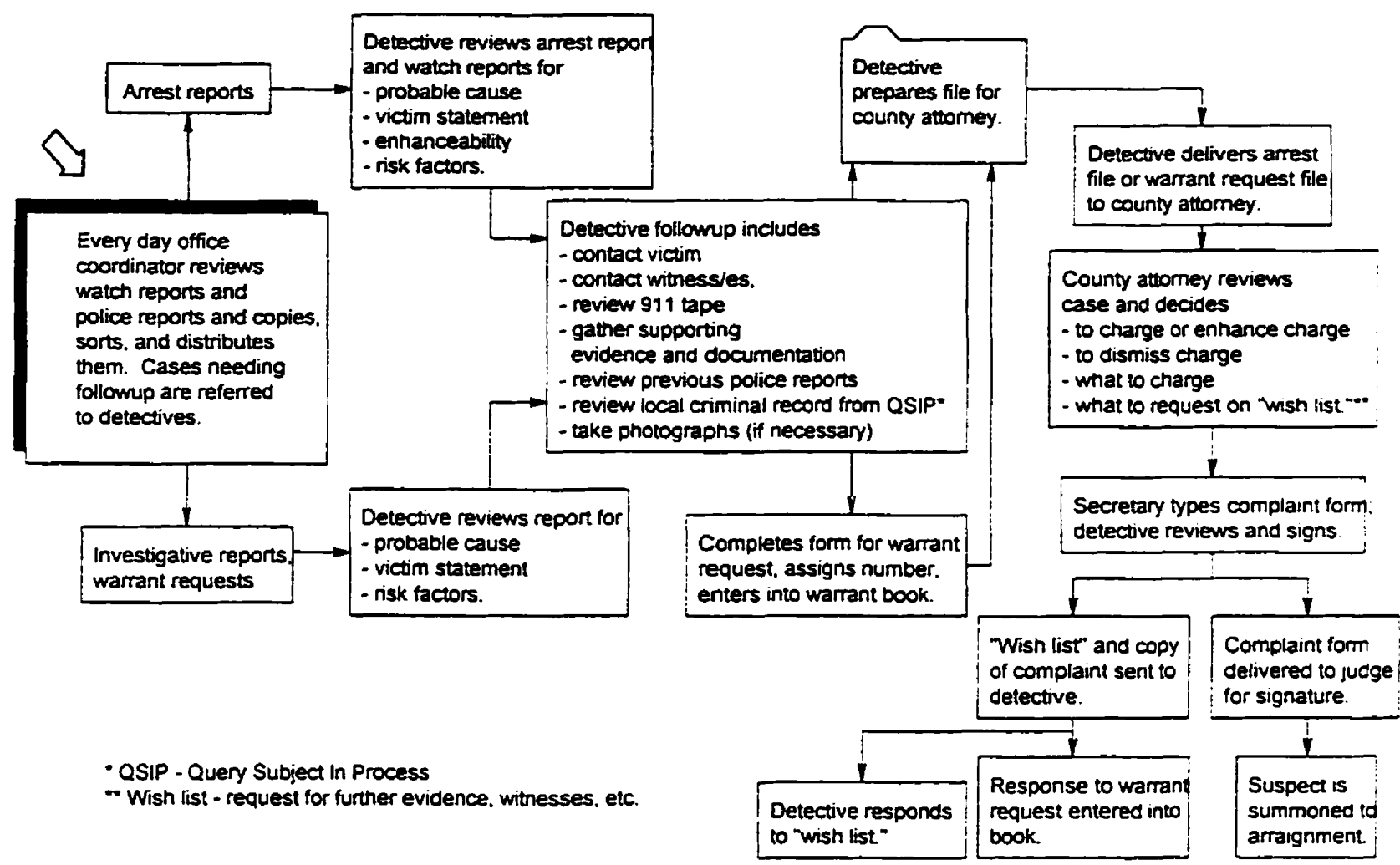

This figure shows the process of the detective bureau in following up on a gross misdemeanor or felony case. Further information and evidence is gathered for better prosecution of a case rather than specifically for providing protection to the victim. The information gathered becomes part of a permanent record and could alert practitioners to how dangerous the situation might be. 
APPENDIX C:

DISPATCHER SCREEN

\begin{tabular}{|l|l|l|l|l|}
\hline SUBJECT & \multicolumn{3}{|c|}{ DOMESP } \\
\hline $\begin{array}{l}\text { PREASSIGNED } \\
\text { PRIORTY }\end{array}$ & AGENCIES & RELATED ACTIVTTY CODE & $\begin{array}{l}\text { ISSUE } \\
\text { DATE }\end{array}$ & $\begin{array}{l}\text { EFFECTIVE } \\
\text { DATE }\end{array}$ \\
\hline 1 & P. PFE & DOMES, DOMESW & $10 / 08 / 90$ & $10 / 08 / 90$ \\
\hline
\end{tabular}

DEFINED:A domestic with a physical assault which has occurred, is in progress or there is a threat of immediate ham. A sttuation which requires immediate response to prevent or curtail violent behavior.

$\gg \quad$ Domestics are the most unpredictable and dangerous calls!

PHONES I. Determine if anyone is injured. If so, dispatch FIRE/IST AND EMS.

- 2. Nre there weapons involved or threat of use.

a. Determine type - update to DOMESW.
b. Are weapons available in the residence?

3. Who?

a. Names of participants.

b. Relationship of those involved.

c. Are all involved still there?

- if assailant is gone, obtain description and method/direction of flight, vehicle involved

d. Is caller involved?

e. OFP on anyone involved?

4. If security building how can squad gain access?

5. If assailant is gone and assault has taken place.

a. When did assault occur?

b. Type of assault and is there visible sign of injury?

c. See DOMESTIC VIOLENCE in NOTES file for MN State Statute $629.34 \mathrm{I}$ and probable cause for artest.

POLICE: Dispatch appropriate number of officers based on circumstances.

FIRE/IST: $\quad$ N/A. Uniess requested by police

$\gg \quad$ Advise to stand by in area until police have scene secured!

EMS: $\quad$ N/A. Unless requested by police

$\gg \quad$ Advise to stand by in area until police have scene secured!

REMARKS 
APPENDIX D: ARREST REPORT

ARREST REPORT

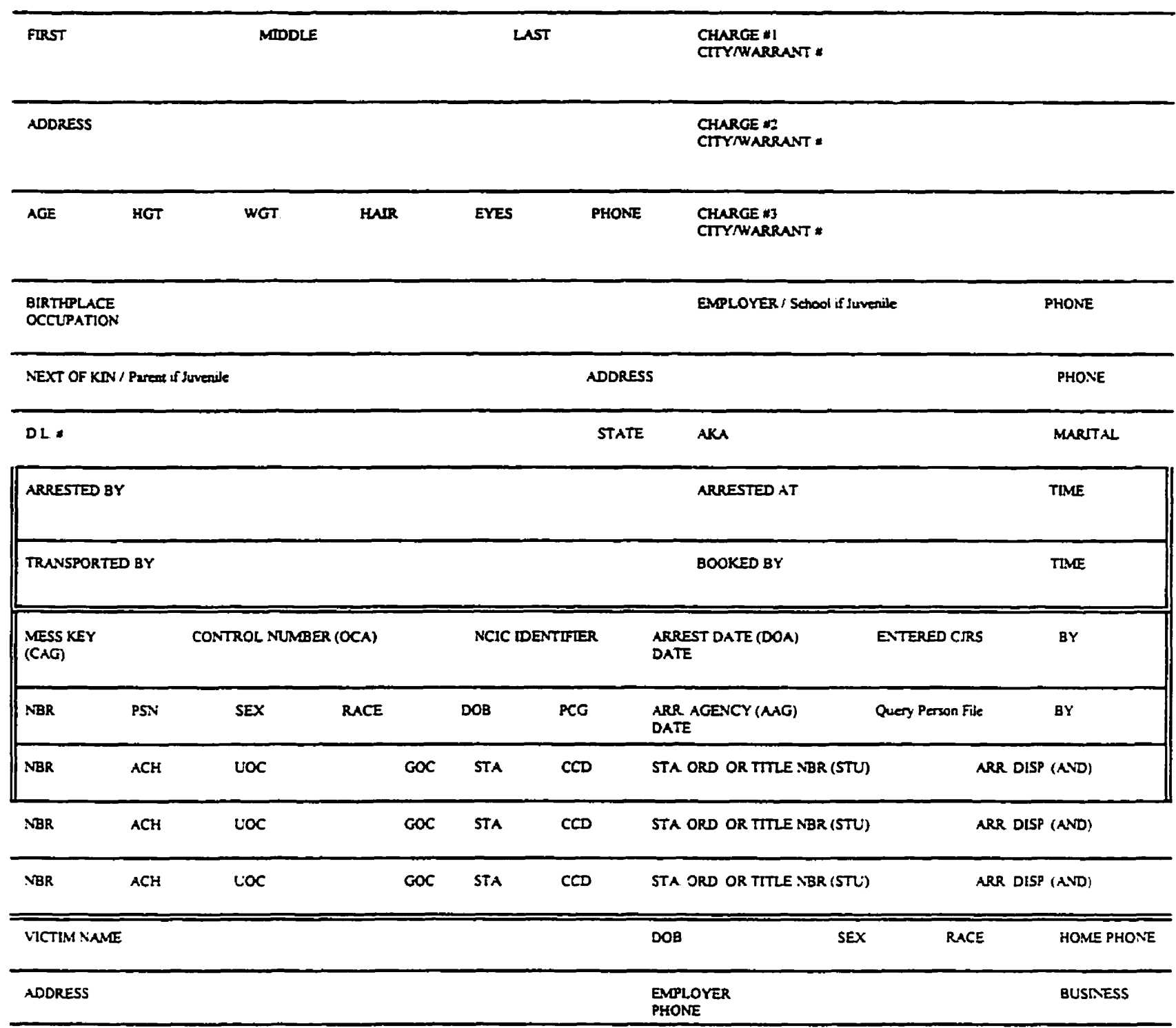

DET AIIS OF OFFENSE / WCIDENT (ff juvenile include names, addresees, phone of parents, school and grace, physieal deseriptron) 
The Court: Mr. Barns?

(Defendant came forward with Attorney Chris T. Holmes.)

The Court: We'll go on record in the matter of State of Minnesota versus Benjamin George Barns. Mr. Barns is also present in court this morning together with his attorney, Mr. Holmes, for sentencing proceedings in connection with an earlier plea to a charge, Felony Assault, Assault in the Fifth Degree, a felony. The Court in this matter has received a PreSentence Report from Mr. Pegg dated February 1, 1995.

Mr. Holmes, you received a copy of that?

Mr. Holmes: I have, Your Honor.

The Court: There are any disputes or corrections?

Mr. Holmes: There are none. We'll place nothing of a factual nature in issue.

The Court: Mr. Torez?

Mr. Torez: Your Honor, we also accept the report as factually consistent with our information and the Guidelines Worksheet as accurate. With regard to the recommendation, we concur with the recommendation of Mr. Pegg in the report.

The Court: Mr. Pegg, do you have any additions or corrections?

Mr. Pegg: Nothing, Your Honor.

The Court: Mr. Holmes, you wish to address the Court regarding disposition?

Mr. Holmes: Well, I have to agree that the recommendations I think are fair. They are consistent with the plea agreement in the case. I'm going to ask the Court to follow those recommendations. That's all that I have.

The Court: Mr. Barns, anything that you wish to say?

The Defendant: Yes, I haven't drank. I've been-since the incident, since I've been out of jail I've been going to AA, and-and spirituality, I-he's kind of the man I see. It's a Native American, Ojibwa ways, spirituality, I've been seeing him at least once a week and trying to get that back together. I've been doing pretty good. Carrie, the victim, would be here today, but her grandfather just passed away. That's about it, I guess.

The Court: The Court then at this time will formally accept Defendant's plea of Guilty as well as his written Petition to plead such that the Defendant now stands before the Court adjudged and adjudicated Guilty of Assault in the Fifth Degree, a felony. As for a sentence, it is the judgment of the law and the sentence of this Court that the Defendant be committed to the custody of the Commissioner of Corrections at Stillwater for a period of one year and one day. Execution of that sentence will be stayed in favor of placing Defendant on probation for a period of two years. Defendant will be ordered to serve 45 days, against which he will be given credit for 45 days previously served such that no additional time in confinement will now be imposed.

Further, the Court will order as conditions of probation that the Defendant remain absolutely free from any use of alcohol or drugs other than that prescribed by a doctor and that the Defendant, at his expense, be subject to random testing. The Court will further order that arrangements be made for the Defendant to complete a Rule 25 Assessment and to comply with or follow through with any treatment or recommendations coming out of that assessment; also that the Defendant be required to enroll in and complete an anger-control counseling program. Mr. Pegg, I assume you have the DAIP Program in mind?

Mr. Pegg: That is correct, Your Honor.

The Court: The Court will further order that the Defendant be obligated to pay the 
mandatory minimum fine plus criminal assessment and surcharge. And I believe the mandatory minimum fine in this matter is probably $\$ 1,000.00$, not a hundred.

Mr. Pegg: Well, Your Honor, because of the assault, they have the special assault statutes under there, and my understanding it was currently Assault in the Fifth Degree. The assaults is not 30 percent of the maximum. It was my understanding it was a flat minimum.

(Pause.)

The Court: In any event, and in light of Defendant's financial situation, the mandatory minimum fine in this matter will be reduced to $\$ 100.00$ plus a $\$ 20.00$ surcharge or assessment fee and $\$ 25.00$ surcharge.

Mr. Barns, that's going to come then to a total of $\$ 145.00$. And if you need some time to pay that, you can make some arrangements with the Court Financial Officer and your Probation Officer.

Mr. Torez, you have anything further?

Mr. Torez: Your Honor, just that I'd ask for, also the Court to impose the sentence on the Count II Obstructing Legal Process as recommended there, that being a 90-day sentence stayed for one year of probation concurrent with the other sentence.

The Court: Mr. Holmes, you have any comment on that matter?

Mr. Holmes: I think that was part of the plea agreement, Your Honor.

The Court: On the charge of Obstructing Legal Process, the Court will impose a sentence of 90 days in the County Jail; execution of that sentence stayed in favor of one year of probation, that year to be served concurrent with the first year of Defendant's probation on the felony and on the same terms and conditions.

Mr. Holmes: Thank you, Your Honor.

Mr. Torez: Thank you, Your Honor

The Court: Thank you, gentlemen.

(Proceedings concluded at 9:12 a.m.) 
APPENDIX F: TRANSCRIPT FROM STATE OF MARYLAND VS. KENNETH L. PEACOCK, SENTENCING HEARING

Case No.: 94- CR- 0943

State of Maryland vs. Kenneth L. Peacock

October 17, 1994

Reporter's Official Transcript of Proceedings (Sentencing)

Before the Honorable Robert E. Cahill, Judge

Appearances:

On Behalf of the State:

Michael DeHaven, Esquire

On Behalf of the Defendant:

David B. Irwin, Esquire

Mr. DeHaven: Good moming, your Honor. For the record, your Honor, Michael DeHaven, Assistant State's Attorney for Baltimore County. We're here for disposition of State versus Kenneth Peacock, 94-CR-0943.

Mr. Irwin: Good morning, your Honor. Mr. Peacock is here present in court. David B. Irwin for the record here on behalf of Mr. Peacock.

Just briefly, for the record, through total chance, my lovely wife, Kendi Mather Irwin, is assigned to you, and I've talked to Mr. DeHaven, talked to my client, and in the normal course of business she wouldn't take down any of my cases.

You have no problem with her being the court reporter today, do you, Ken?

The Defendant: No.

Mr. DeHaven: Certainly no objection on behalf of the State.

The Court: Nor does the Court.

Mr. Irwin: We're ready. We're ready for sentencing.

The Court: Let me state at the outset that I did have the opportunity to review Mr. Irwin's sentencing memorandum, pre-sentence memorandum, as well as letters which were forwarded under a cover letter of October 13. I've read all of those. I've reviewed my notes of the sentencing hearing.

Were the guidelines previously submitted?

Mr. Irwin: We have agreed they're three to eight years. I don't know if they've been submitted.

The Court: That's what my notes indicated, it was three to eight.

Mr. DeHaven: I would submit them. Actually I'll finish them up.

The Court: Go ahead, finish those. I had a note to that affect.

And my notes also indicate, of course, that the State's position in return for the plea to the charge of manslaughter was that the Court impose a sentence within the guidelines. And all of that is reflected in the memorandum of the plea negotiations, signed by the defendant and counsel. And it appears for the record that as a result of those plea negotiations this was simply a one-count information; is that right?

Mr. DeHaven: Yes, your Honor. The information charged first degree murder.

The Court: Charging first degree murder, but this is the plea to the lesser included offense with that, correct?

Mr. Irwin: That's correct.

Mr. DeHaven: That's correct, your Honor. I'm submitting the guidelines at this 
point, which do reflect that.

The Court: I'm saying that for the edification of my court clerk, who will ask me what count it is, and I never know. Is there anything, Mr. DeHaven, that you wish to add at the outset?

Mr. DeHaven: At the outset, or is the Court going to give me another opportunity after defense? I would prefer to have the defense go, and then the State will give its recommendation. Nothing further at this point based on the defendant's memorandum.

The Court: Go ahead, Mr. Irwin.

Mr. Irwin: The only thing that Mr. DeHaven and I have discussed, that I'm sure he'll talk to the Court about, he and I have talked to Mary Lemon. Mary Lemon is Sandra Peacock's mother and would in essence be the input from the victim's family.

The Court: I noted that I had nothing on that.

Mr. Irwin: And I'm sure Mr. DeHaven will cover that point for the Court.

Your Honor knows that Mr. Peacock is thirty-six years old, no prior brush with the law. He has got a wonderful family, many of whom are here. Eugene Manifold, his employer, is here, whose letter you have read, Bruce Peacock and his wife, Michelle. Bruce is the twenty-year veteran, whose letter you've read, Mike Hertzog, his friend, whose letter you have read, Barbara Bauer, his fiancée, Bruce Peacock, Sr., the thirty-eight year employee of the Baltimore Gas and Electric company, who is Kenny's father, who is here today with his stepmother, who loves him dearly. You have read her letter, and Mr. Peacock, Sr.'s letter. His mom, Jane, is here today, and Lisa Stinson, a friend of the family. They're all here.

A lot of times lawyers say, Boy, it would be nice to be a judge today, I wouldn't have to come in and prepare, I could sit up there and be a referee have a nice parking place downstairs and all that. But I'm sure this is the one time-

The Court: Except for the newest judge, who has to park against the wall.

Mr. Irwin: Oh, good point. I see the Court of Special Appeals judge has to park across the street.

The Court: That's right. He is not happy about that at all.

Mr. Irwin: But at any rate, it goes without saying this is a time where nobody wants to sit in your [the judge's] chair up there. This is obviously the hardest job a judge ever has.

You have got on the one hand a beautiful family, a kid who has worked his whole life. He marries a lady he is in love with, he has been married five years, and for the second time he finds her in this tragic situation [having sex with another man].

He has a fatal flaw. He is an alcoholic. I've had him evaluated. He has met a couple times with Nick Gianpietro, a certified alcohol evaluator. And based upon what happens today, it is obvious he has to be in some kind of program, whenever he is not incarcerated, if he is not incarcerated from the outset, or later on, he is going to need treatment for that. It is a disease that runs in the family.

And when you mix alcohol, emotion, the incredible emotion of the situation he found himself in, and firearms, a tragedy happens. And Sandra Peacock, for all her fragilities, it is a tragedy that she is deceased.

From the one hand, the State obviously cries out for justice, we need jail time. He is a wonderful person, but we can't have a death, so jail time is certainly appropriate for them to recommend.

It is certainly appropriate in our situation with this beautiful family-the problem, he has got two brother that are police officers, and I would worry about his safety down 
there. Bruce is a twenty-year veteran, Brian is an eight-year veteran. Brian served in Desert Storm. Kenny didn't become a police officer mainly because he started working and getting a real paycheck ever since junior high school. He has worked every day that he could his entire life, as you know.

Work is his therapy. Since he was released after serving sixteen days in jail before he got out on bond, he has been working every trip he could work. Mr. Manifold [his employer] took the trouble to come down from Pennsylvania, he is in the back, the gentleman in the tie and coat, he took the trouble to come down here. He needs him to work. You have seen letters from his customers, he is nice and polite.

What the heck, why are we here? Again, it is that incredible confluence of alcohol, firearms and high emotion that shouldn't ever be put into the same equation.

You know all the facts of this case. You know everything. The one thing you don't know is that he keeps working hard to do his obligations. One of the things, Sandra, because of her drinking, and she had a gambling addiction to playing Keno at these bars. Everybody says Keno is a great thing, but she spent hundreds of dollars a day playing Keno, of his money, her money. They left a lease. They were at the farm where they were, after they had left a lease in another apartment where he believed she had paid up the landlord, settled with the landlord. The landlord still is owed eleven hundred bucks. We had to work that out. He had been paying $\$ 100.00$ a month just settle that. He didn't even know that that existed. We worked that out and went to rent court with him and worked that out. He has paid his lawyer bills slowly and on time. I'm fully paid. The landlord is being paid. He is just a tax-paying great member of society.

But what do you do with him? My suggestion, your Honor, is of course I think that there is a rationale, and because of all this, you could hang your hat on giving him probation, strict probation, alcohol treatment and all that. If you can't swallow that, which a lot of judges wouldn't have the courage to swallow in a situation like this, because of the loss of life, I would strenuously argue that it would be severe punishment for him to be locked up in the Baltimore County Detention Center for up to eighteen months, which is the longest you could give him, recommend work release, so he can pay his taxes, pay for his room and board, and be punished. Also community service, alcohol treatment. He would have-he would be locked up, his freedom would be lost, which would be important to him, a message would be sent to the community, if that's necessary in this case, which I honestly don't think it is, under this circumstance as a deterrent for a spousal infidelity, classic manslaughter case, I don't know that you can send a deterrent to somebody and make them think twice before they do something like this.

But I understand what the Court-I'm not the Court, I can't understand all the pressures you have, but I can guess at the pressures in a case like this. I would strenuously argue for that as opposed to a sentence in the Department of Correction.

And I'm not going to go on and on, when it is obvious what the points are here. I would just say that I have talked to Mary Lemon, and Mr. DeHaven was nice enough to share with me a little about what she said. She is a very religious lady. She prays for her daughter. If she were her, she would tell you about her daughter's frailties and how nice Ken was to her son from a prior marriage. That son wasn't living with here because she wasn't considered to be a mother that could handle a son, and the grandmother, Mary Lemon, is raising that boy down in Texas. But she would say she understands his problem and sympathizes very much with Ken. She's a religious woman who does not believe that a life should be take as a result of this, even this horrible situation, and that she prays for your Honor as well as Ken, and prays for Sandra, that all this will all come out right in the 
140 Lord's eyes. I hope it does. She has told me she has no animosity towards Ken. I'm sure 141 she wants to see justice done, whatever that is, and I'm sure she's going to be another one 142 that passes that up to you, passes the buck up to you. But I just wanted to say for the

143 record, she was very cordial to me, the defense attorney. I was amazed at how cordial and 144 friendly. And she's just a fine lady.

Thank You, your Honor.

The Court: All right. Before I hear from the defendant, Mr. DeHaven?

Mr. DeHaven: Thank you, your Honor. Your Honor, I did speak, as Mr. Irwin stated, to Mrs. Lemon this morning. Basically what she told me is that she has mixed feelings about this. I asked her quite some time ago, if she could, to articulate in a letter to you or to me how she feels about this case, and basically give her victim impact statement so that the Court could be fully aware of what is going on. She couldn't [do] that. She told me she was thinking up until the moment I called her this morning what to say. And she indicated to me, again, she has mixed feelings.

She indicated to me on one side, and I'm going to incorporate the State's argument of course along with this, but basically her feeling is the State's feeling as well, you[r] Honor. She indicated to me that on one hand she can see her daughter provoking the anger that it did, and causing the anger that later led to this incident. And as we talked all along about this case, I said, well that was the reason basically the State agreed to proceed on the manslaughter charge. The State believed that provocation was sufficient to proceed just on the manslaughter as opposed to the murder in this case.

And she talked about the other aspect of her feelings, and that is what the State is going to argue to you today, that the defendant should be punished for his actions. The defendant had an opportunity to walk away that night. It is clear that the defendant decided to take matters into his own hands, to pick up that gun, to pull the trigger, and eventually took the life of another person. Mrs. Lemon indicated to me she believes this Court should punish the defendant appropriately.

The State believes that appropriately in this case means a sentence of incarceration within the guidelines. They are three to eight years, your Honor. As the Court notes from the guideline sheet, nothing has to do with the offender score. The defendant up until this point, his life, he has been an exemplary citizen. In fact, remains so even while out on bail awaiting sentencing today. The State does not believe that really he is going to be a threat to society when he gets out. I do believe this is an isolated incident.

However, your Honor, the offense score-I won't say mandate, because we're not anywhere near Federal Court-suggests-

The Court: You can say it. It simply isn't.

Mr. DeHaven: - suggests to this Court a sentence of incarceration between three and eight years. The State fully believes that based on the offense in this case, three to eight years incarceration in the Division of Correction is the appropriate sentence.

With that, your Honor, I would submit to the Court.

Mr. Irwin: Kenny, now, as we discussed, you have a right of what is called in the law allocation, which means you can say anything you want to Judge Cahill at this time before he passes sentence on you. Do you have anything to tell him?

The Defendant: I would like to tell your Honor I'm very sorry about what happened. I can't change what has happened. I would like to continue working, and it helps me out mentally and everything. I'm just willing to accept whatsoever you will do for my actions. That's all I can say.

Mr. Irwin: Thank you. 
The Court: You are blessed with a very supportive family.

Mr. Irwin is correct, that people who meet judges for the first time frequently, those not acquainted with the system, frequently ask what is the most difficult thing that you have to do. The old saw is that it is decide custody, but that truly is not the most difficult thing that a judge is called upon to do. The most difficult thing that I have found is sentencing noncriminals as criminals.

This case is very similar and equally tragic to the very difficult manslaughter by automobile cases that I've handled in the past year. The consequences are as tragic. I was called upon to sentence a young man who while driving under the influence killed his brother.

I recently had to sentence a noncriminal citizen, a lady who had attended Christmas parties last December or a Christmas party, overindulged and got on the ramp going the wrong way and killed her best friend, leaving two children that that lady was supporting.

And previously I was called upon to sentence an individual, an employee of Xerox who had never had a brush with the law in fifteen years and had had a prior ticket of some nature up in Pennsylvania, but while driving home after his wife had left him sometime before and having had too much to drink one night, he struck and killed a ten-year-old child on a bike.

Those are brutally difficult choices. This [trial of Kenneth Peacock] is nonetheless, it is equally as difficult. There is a distinction. The courtroom contains visitors only on one side, and so I get the benefit of in effect sentencing in anonymity. I don't have Mothers Against Drunk Drivers present. The chances are this case will not even be written up. There is a chance that it might because of the current emphasis on spousal violence and that phenomenon is our society.

This judicial conference, where all the judges of this state gather once again because the budget constraints allow it, for two years we had none, but that meets here in Towson a week from Thursday, and upwards of 250 judges will be present. The sole topic for the two-day meeting is domestic violence. I will certainly go with a great deal of current experience, when I attend the conference.

You could not fictionalized a more tragic circumstance than this. On the one hand there is real sympathy for the defendant and how he should have reacted to this terrible situation. You ordinarily would not have such an explicitly factual explanation for the circumstances, whereas here the third party was available to explain the circumstances of the evening, which could only have made it worse had the defendant known those facts.

But the victim is nonetheless a victim, and she is deceased. And her mother will never be the same. Nor will the defendant. Nor will his family. That, too, is tragic, but that's part of life.

The guidelines-I understand the State's position, I don't quarrel with it. I think the State has been extremely fair in this case. I don't always say that. But generally I do, and certainly this case is a case where the State has acted with great recognition of its responsibility to the individual, the decedent, the victim, and the public. It is easy to say now that this is simply a manslaughter case, but that's what it is.

Manslaughter is a serious offense, as the guidelines indicate. Three to eight years for a first offender is a heavy sentence. And for those who have never had the misfortune of spending a day behind bars, they can't understand how heavy that is, because I say we're dealing here with an individual who by his background is a noncriminal. He now is a criminal, unfortunately. All the more difficult, his brothers are in law enforcement, and have had long, having seen the rest of the family, I would expect, distinguished careers in 
law enforcement.

But what do we do with Kenneth Peacock? The two elements of sentencing, the cases tell us, are the individual, the deterrent aspect, the background of the individual, and punishment. I agree with Mr. Irwin, that just as in vehicular manslaughter cases, my sentences in the three cases I mentioned will not prevent other people from killing people with automobiles. I do think that the most recent case could have a great effect on the one where the poor unfortunate middle-aged woman killed her girlfriend after a Christmas party. It might save some lives this Christmas if she carries through with her agreement to allow that unfortunate incident to be used.

But, generally speaking, I can't prevent the next vehicular homicide. But, also, I must take into account that Mothers Against Drunk Drivers have accomplished a great deal in recent years to stop the whole of deceased people on the highways. Had they not been around in recent years, we might still be killing people at a much higher rate, and driving when we shouldn't be driving. And I say we.

But whether or not the sentence in this case will deter, I can't really say. I would hope that it does. But I cannot think of a circumstance whereby personal rage is uncontrollable greater than this for someone who is happily married. And that is not mere lip service, it is a fact. To be betrayed in your personal life when you are out working to support the spouse under the heightened circumstances of this case are almost unmanageable, I would think, even if a person did not have alcohol as a contributing factor.

I guess Mr. Peacock's single greatest problem is this case is the alcohol, but it does require some kind of sentence as a deterrent just as motor vehicle manslaughter by intoxication requires sentences. Judges simply can't say, in spite of how excellent the person's background may be, that appearing before the Court is enough, because there are other people watching and listening.

So I am forced to impose a sentence in this case in my mind, not forced by any guidelines, not forced by any third parties, but only because I think I must do it to make the system honest. I have no question in my mind that no judge of this circuit and probably no judge of this state will ever see Kenneth Peacock again. That's why I'm not overly concerned in light of his history since this event and what he has done awaiting sentencing, I'm not real concerned about probation, the terms of probation, things of that nature. I think that will work itself out very quickly.

But I cannot send a message, and it could be interpreted this way, that if even under the most extreme circumstances you have a personal disagreement with a family member, you can settle it the way this ultimately got settled. And I give the defendant the benefit of the doubt, the fact that this was not a contact wound, that it could well have been rage and accident. But alcohol and rage creates that kind of accident, the same as alcohol and driving an automobile create fatal accidents and fatal outcomes.

So I can at least look to my past in sentencing those cases and try to make this make some sense with those cases. It has been made easier again by the State's frankness with respect to the victim's mother, and Mr. Irwin doing his job the same way. She is a very responsible lady, obviously. She has found her way to accept the system and trust that the person who has the difficult job of administering will do that job. This is not the case in vehicular homicide cases, I can tell you that. I sat either in this courtroom or the one next door for forty-five minutes alone [with] the victim's father in one of those cases. But Mary Lemon certainly has acted responsibly in this case. Perhaps it is her faith in God that made it easier for her to do that.

So I must impose a sentence on Mr. Peacock. I had checked this morning to find 
out whether work release was available to a person who drove out of state. I'm told that it is. And I'm impressed by Mr. Peacock's statement that he needs work release to get by mentally. Dr. Spodak in his report has simply said, and I know you heard this from Mr. Irwin, Mr. Peacock, that you have an alcohol problem.

The Defendant: Yes.

The Court: And he put another psychiatric label in there, which I'm not surprised at, because there are labels, but what he really has in an alcohol problem. Like some other people, it is easier said than done, but like some other people, you just have to stay away from alcohol, that's all. No more tragedies with no more alcohol. Your thinking will be clear.

But I must, as I said, impose a sentence as a deterrent and as somewhat of punishment for your, as the State put it, not walking away. I seriously wonder how many married men, married five years or four years would have the strength to walk away, but without inflicting some corporal punishment, whatever that punishment might be. I shudder to think what I would do. I'm not known for having the quietest disposition. Had you done that, you probably would have seen this Court in a different fashion, in a marital case. And that's extremely unfortunate for you. But I sense by your actions that you will handle this. And I don't know if you would handle or benefit or the public would benefit in any way by placing you within the Division of Correction.

So the sentence of the Court is that I will impose, and I think I have to say the first part, a sentence of three years-because under any stretch of imagination these facts would be the minimum of the guidelines, and I don't see the necessity of having the classic something hanging over your head aspect of sentencing, it doesn't exist in this case- - to the Division of Correction for three years, suspend all but the eighteen months to be served at the Baltimore County Detention Center. As I said, I already spoke to the major this morning. I recommend work release immediately. I also will recommend, but leaving to the professionals the time for it, home detention, when the authorities deem it appropriate. That is generally speaking up to the people who do a very good job of running the work release program. It is not going to be pleasant, I can assure you of that. They're sleeping on the floors in the work release facility. We simply don't have any beds out here right now. But you will have to be very, very strong and get it behind you as quickly as possible.

Upon his conclusion of eighteen months or that portion of it, I'm going to place Mr. Peacock on probation for a period of one year. And the sole purpose of that probation in this case, because I think the family will remain as supportive as they have been, the sole purpose of that is to have someone looking over him with respect to alcohol in that first year of release. You will have to abstain from alcohol during that period of time. You will have to be evaluated. And because your job is not the best type of job to have if you have an alcohol problem, and I know that from experience, seeing, in cases that I've handled, during the one year of supervised probation, you will have to submit random urinalysis, and participate in an Alcoholics Anonymous program to be with the assistance of TASC. If at all possible, I am also going to, as a condition of probation, require that the defendant not participate in the domestic violence program, but that he render assistance to domestic violence programs in existence in the form of fifty hours of community service, which could be spent allowing his dreadful and tragic experience to be used as an example that would help others. But I do require that that fifty hours be spent in that very limited fashion.

I didn't check, Mr. Irwin. Has Mr. Peacock spent any time? 
Mr. Irwin: Sixteen days, your Honor. February 9 through February 24. The 24th was the day you got out?

The Defendant: Yes.

The Court: All right. The eighteen months to begin sixteen days ago, or the date of beginning, so he will receive full credit for the time of incarceration. And as I said, it will be spent at the Baltimore County Detention Center.

During the period of probation, because you already-you have conducted yourself as a responsible citizen pending the disposition in this case, I'm going to also require that you pay the supervisory fee of $\$ 25$ per month. Had you been a ne'er-do-well, I might not have done that, but that's appropriate under the facts in this case. And you will pay the costs of this proceeding, either during the period of work release or during the period of probation.

Mr. Irwin: Your Honor, thank you very much for your thoughtful sentence. I will advise my client.

Ken, technically you have certain rights now. You have thirty days to file a petition with the Court of Special Appeals, as we explained at the time of the guilty... plea. You don't have an automatic right to appeal. You have very limited rights and it is basically not a worthwhile process, but I have to advise you you have thirty days to file it.

Because you have a three-year suspended sentence, you have thirty days to file for a three-judge panel, which Judge Cahill would not be a member. They could increase the sentence, leave it the same, or reduce the sentence. After hearing the facts, I strongly advise against doing this, because I think this is the most merciful sentence a judge could fashion for you.

I also have to tell you we have ninety days to file for this judge to reconsider this already merciful sentence, and we'll talk about that.

I would like to also say on the record I appreciate the State's seeking justice in this case.

Mr. DeHaven: Your Honor, one more thing to clear up as well. Should the defendant violate a condition of work release, would the Court consider that a revocation of probation and that the defendant would serve the three years in the Division of Correction?

The Court: I know that you office has been asking us to do this, and I frankly am confused by it. So I guess I'll do what I did the last time and say no. I certainly would consider the circumstances of what happens at the time. But the mere fact of saying now that violation of work release, which could be being late, could result in that, I simply can't do it. I have to deal with things as they occur, so I will not require that. But it happens any ways, if it happens.

Mr. DeHaven: Right.

Mr. Irwin: Thank you, your Honor.

The Court: Thank you, gentlemen.

Mr. Irwin: Does the system work now that he goes with the sheriff immediately? I had told him to be ready for that.

The Court: Yes. Because I think work release can be available so quickly.

Mr. Irwin: Fine. That's fine. We would rather get moving on it. Thank you.

Mr. DeHaven: May I be excused, your Honor?

The Court: Yes. Thank you, Mr. DeHaven. 
Address:

Cirv:

State

Victim comments:

\section{LEGAL STATUS}

Are you or have you ever been on probation or parole? Yes Probation/Parole Officer:

No___ If yes, when?

Other charges pending?

PHYSICAL AND MENTAL HEALTH

City/State

Physical Condition:

Psychological or psychiatric care:

How much do you spend gambling:

AlcoholDrug usage:

Wanted on a warrant?

Victim of incest, domestic violence, or sexual assault?

Ever thought of or attempted suicide?

DEFENDANT'S STATEMENT AND ATTITUDE:

PRIOR RECORD

\begin{tabular}{|l|l|l|l|}
\hline OFFENSE & DATE & PLACE & DISPOSITION \\
\hline & & & \\
\hline & & & \\
\hline & & & \\
\hline & & & \\
\hline
\end{tabular}

ADDITIONAL INFORMATION:

RECOMMENDATION:

Respectfully,

Title

Arrowhead Regional Corrections, Probation Dept.

100 N. 5th Avenue West, Room 319

Duluth, MN 55802

mispsi.frm 7/95 


\section{ARROWHEAD REGIONAL CORRECTIONS \\ St. Louis County \\ PROBATION AGREEMENT}

On the day of

19 you appeared before the Honorable

Court, County for the offense(s) of Judge of District and were sentenced as follows:

\section{SIXTY (60) DAYS IN THE COUNTY JAIl; TIME STAYED FOR ONE (1) YEAR SUPERVISED PROBATION.}

\section{GENERAL CONDITIONS}

1. I will obey all Stare and Federal laws and local ordinances.

2. I will report to my Probation Officer as directed:

3. I will obtain permission from my Probation Officer before leaving the State.

4. I will not change residence or employment without prior approval of my Probation Officer.

5. I will immediately notify my Probation Officer if I am arrested for any reason.

6. I will cooperate with and be truthful with my Probation Officer in all matters.

7. I will comply with any additional requirements imposed by the Probation Officer.

8. I will not use drugs or alcohol unless prescribed for me by a physician.

9. I will submit to any request for drug/alcohol testing at my own expense.

10. I will comply with all institution/program rules.

II. SPECIAL CONDITIONS

I will abide by the following special conditions set forth in my sentence:

1. FINE \& FEES WAIVED.

2. ENTER \& COMPLETE THE DOMESTIC ABUSE INTERVENTION PROJECT, CONTACT TY OR DON AT 722-2781 WITHIN FIVE (5) WORKING DAYS FOR AN APPOINTMENT

3. NO SAME OR SIMILAR INCIDENTS

III. FIREARMREGULATION

I understand that under the Federal Gun Control Act, any person who has been convicted as a felon cannot lawfu!ly own, use or possess a firearm until the conviction is expunged, set aside. pardoned, and until permission is granted by the Department of Alcohol, Tobacco and Firearms.

IV. CIVIL DISABILITY

When a person is convicted of a felony either by plea of guilty or verdict, or placed under supervision on a Stay of Adjudication, certain civil rights are immediately lost. Rights lost include:

1. The right to run for or hold public office.

2. The right to vote.

3. The right to serve on a jury.

\section{WAIVER OF EXTRADITION}

I do hereby waive extradition to the State of Minnesota from any jurisdiction in or outside the United States where I may be found.

I fully understand this probation agreement. I understand that if $i$ am alleged to be in violation of any of the above conditions. a Hearing may be held to determine if my probation will be revoked. If the court finds that I am in violation of the conditions it has the authority to restructure my probation or incarcerate me.

I accept the privilege of being on probation and will comply with all these conditions. I have read and/or have had read to me the above conditions and fully understand them and have received a copy.

Date: 
PROBATION OFFICERACTION OMisd.

Advise victim in writing of disposition of case

- $\quad$ Advise victim in writing of dispositio

- Warn victim of dangerousness

- Initiate or participate in Emergency Response Team to strategize and provide community protection

\section{RECOMMENDATION TO COURT}

\section{Offender Accountability Measures}

Recom-

mended

- No. days served

- Serve time in addition to probation, No. days

- No. days stayed

- Mesaba Work Release Program, No. days

- months probation

- Contact with P. O., Frequency

- Type of contact with P.O. probation reporting service in person _ by telephone _ automated

- Random urinalysis

- Fine/Community service, Amount

- Sentence to service (manual labor) additional consequence

- Attend Violence Impact Panel

Victim Safery Measurements

Recom-

mended

- No contact with victim

- Cannot be at victim's residence

- Assessment for visitation arrangements

- Electronic monitoring if separated, Type

- Removal of weapons

- Compliance with Order for Protection

- Additional restrictions

Offender Rehabilitation

Recom-

mended

\begin{tabular}{ll} 
- & DAIP program for offender \\
- $\quad$ CD assessment/treatment/abstinence \\
- Parent groups \\
- $\quad$ Psychiatric evaluation \\
- Individual counseling \\
- Take medications if necessary \\
\hline
\end{tabular}

Additional Comments: 
